UNIVERSIDADE DE SÃO PAULO

FACULDADE DE FILOSOFIA, LETRAS E CIÊNCIAS HUMANAS

DEPARTAMENTO DE LETRAS CLÁSSICAS E VERNÁCULAS

PROGRAMA DE PÓS-GRADUAÇÃO EM LITERATURA PORTUGUESA

Joana Souto Guimarães Araujo

“Com palavras amo": um estudo das imagens em poemas de Eugénio de Andrade 
Joana Souto Guimarães Araujo

\title{
"Com palavras amo": um estudo das imagens em poemas de Eugénio de Andrade
}

\author{
Dissertação de Mestrado, apresentada ao \\ Programa de Pós-Graduação em Literatura \\ Portuguesa do Departamento de Letras Clássicas e \\ Vernáculas da Faculdade de Filosofia, Letras e \\ Ciências Humanas da Universidade de São Paulo, \\ para obtenção do título de Mestre em Letras.
}

Área de concentração: Literatura Portuguesa.

Orientação: Prof. ${ }^{a}$ Dr. ${ }^{\text {a }}$

Mônica Muniz de Souza Simas.

São Paulo

2012 
Nome: ARAUJO, J. S. G. "Com palavras amo": um estudo das imagens em poemas de Eugénio de Andrade. Dissertação de Mestrado, apresentada ao Programa de PósGraduação em Literatura Portuguesa do Departamento de Letras Clássicas e Vernáculas da Faculdade de Filosofia, Letras e Ciências Humanas da Universidade de São Paulo, para obtenção do título de Mestre em Letras.

Aprovado em:

Banca Examinadora

Prof. Dr. Instituição:

Julgamento: Assinatura:

Prof. Dr. Instituição:

Julgamento: Assinatura:

Prof. Dr. Instituição:

Julgamento: Assinatura: 
Aos meus pais. 


\section{Agradecimentos}

Ao apoio financeiro e acadêmico da FAPESP, imprescindível para a realização da pesquisa.

À orientação da professora Mônica Muniz de Souza Simas, que, com generosidade e paciência, me ensinou a estar perto dos poemas de Eugénio de Andrade. Agradeço por todas as longas conversas, nas quais tanto aprendi sobre o trabalho, sobre poesia, sobre o ofício de professora, sobre a vida.

Às professoras Paola Poma e Annie Gisele Fernandes, que participaram do exame de qualificação, acolhendo o trabalho com carinho e atenção. Agradeço pelos caminhos abertos.

Ao meu pai e a todas as tardes que estivemos juntos até hoje, principalmente aquela em que me apresentou alguns poemas de Eugénio de Andrade.

À minha mãe, que me ensinou praticamente tudo. Agradeço a revisão do texto e o sorriso esculpido de Eugénio de Andrade.

Ao Daniel Bonomo, pelo amor, pelo incentivo, pelas conversas.

À alegria de minha irmã Júlia, do meu sobrinho Pedro e de meu cunhado Felipe.

À Felícia Hahne, e a todos os poemas que lemos juntas, no papel e nas coisas da vida.

Ao companheirismo e incentivo de Ana Cândida e Andrei, sem os quais eu talvez não teria começado a pesquisa.

Às conversas amigas e às contribuições essenciais de Giovanna Gobbi e Mari Bolfarine.

Aos meus sogros e à Gabi Bonomo, pelo constante apoio.

Aos amigos Alê, Pedro, Caru, Helano e Fabi, pela convivência e proximidade nesses anos de pesquisa. 


\section{Resumo}

Na poesia de Eugénio de Andrade (1923-2005), a mudança não constitui propriamente um desligamento ou uma ruptura, mas um reencontro. Sua poesia persegue, na transformação, a possibilidade de permanência, e assim constrói, por meio da continuidade de seus elementos, um movimento cuja variação desperta uma série de associações ou ressonâncias. Com vistas na dinâmica fluida dessa poesia, esta dissertação de mestrado propõe uma análise de signos e disposições imagéticas recorrentes em Poemas (1945-1965), reunião da primeira fase de sua obra, publicada em 1966. Muitas das imagens selecionadas, motivadas pelos temas do amor e do fazer poético, traçam movimentos de deslocamento e expansão, e serão lidas como alusões à palavra poética, que, ora em nascimento, ora em transformação, sublinha a existência de uma estrutura poética autônoma e autorreflexiva. Desse modo, identificamos núcleos poéticos em cada um dos sete livros da coletânea, movimentados por signos centrais, que se desenrolam, confrontam-se, e permitem uma leitura conjunta dos poemas. Por meio de prefácios e poemas de abertura, seguidos de outros poemas e trechos relevantes, pretendemos investigar a formulação de uma concepção poética, que se revela, antes de mais nada, em permanente renovação, evidenciando esforços afirmativos contra a paralisia do sujeito e em diálogo com a condição crítica do mundo moderno. Pois, ainda que a poesia de Eugénio de Andrade procure sua expressão na própria realidade das palavras, não deixa de manifestar um momento histórico em que o sujeito enfrenta a consciência dolorosa de um mundo caótico, fragmentado, e separado da natureza.

Palavras-chaves: Eugénio de Andrade, arte poética, signo, imagem. 


\begin{abstract}
This dissertation aims at analyzing the main poetic signs and images in Poemas (19451965), collection of the first poetry by the Portuguese Eugénio de Andrade, published in 1966. Many of the selected images, read as allusions to the poetic expression, draw movements of dislocation and expansion, revealing an autonomous and reflexive poetic structure which remains in perpetual transformation. In each one of the seven books included in the collection, we identify a poetic nucleus developed around a group of poems, linked by a dominant and recurrent sign. The dynamic of rotation and repetition of signs and images prescribe movement to the poetry by Eugénio de Andrade, organizing cycles that narrate stories of love and poetic emergence, from its birth to its decease or exhaustion, usually lamented by a tragically abandoned poetic subject. Our corpus constitutes of the preface, the opening poem of each of the seven books, as well as other relevant poems and extracts. The main purpose is to investigate the formulation of a poetic conception which reveals itself in constant change and reformation, seeking permanence through the very act of transformation. Its affirmative efforts can be read in association with the tensions lived by the modern individual, who constantly tries to overcome his particularly conflictuous historical moment - in which his fellow men can only face a chaotic and fragmented existence, distant from nature and from any kind of reconciliation.
\end{abstract}

Key words: Eugénio de Andrade, ars poetica, sign, image. 
Que posso eu fazer senão escutar o coração inseguro dos pássaros [...] e perguntar o que aconteceu ...

Eugénio de Andrade. 


\section{SUMÁRIO}

1.Introducão

.p. 9

2. A poética eugeniana e algumas tensões da modernidade estética

2.1 Entorno histórico-literário

p. 28

2.2 Anos de "combustão verbal" .p. 33

2.3 "Rostos do homem"

p. 40

\section{Dos Poemas (1945-1965) à ideia de uma arte poética}

3.1 A "palavra", a "terra" e o "homem" no prefácio "Poética" .p. 44

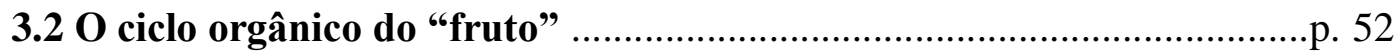

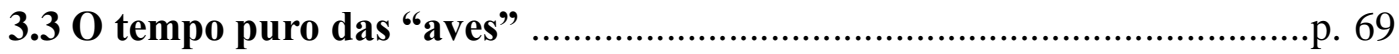

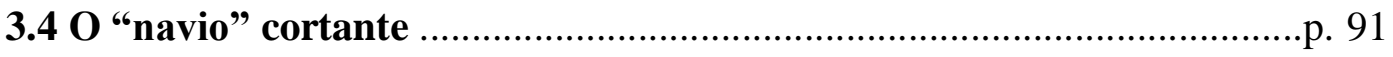

3.5 A sempiterna "chama" .................................................................p. 116

3.6 As “águas" diurnas ....................................................................p. 143

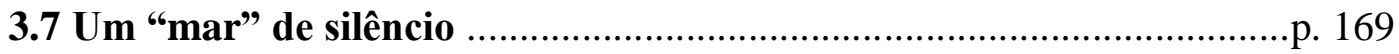

3.8 O “verão" da "luz" e dos “frutos" maduros .......................................p. 192

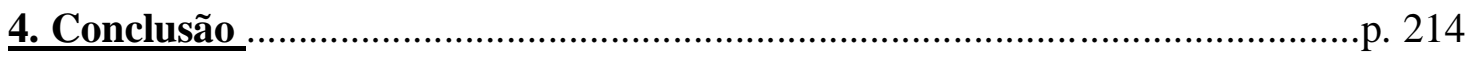

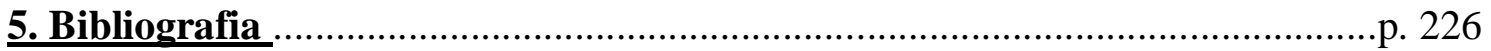

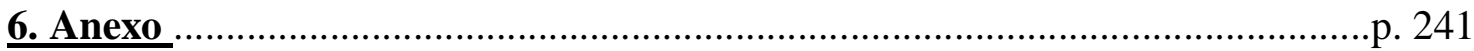




\title{
1.INTRODUCÃO
}

\author{
Nós só não perderemos a realidade se corrermos \\ sempre atrás dela a refazer imagens \\ (Óscar Lopes, 1969, p. 200)
}

É da opinião de muitos críticos que o vocabulário da poesia de Eugénio de Andrade (1923-2005) mantém-se reduzido a termos poucos e repetitivos ${ }^{1}$. Com efeito, a repetição é um procedimento poético que cumpre com uma dinâmica variada e implica diversas gradações de sentido. No caso da poesia eugeniana, as recorrências podem ser lidas como marcas de uma poética que se pensa e se escreve sob o signo da busca e da inquirição. Nosso objetivo é acompanhar, ao longo de Poemas (1945-1965), coletânea dos sete primeiros livros do poeta, as recorrências de signos e imagens organizados naquilo que identificamos como "núcleos ondulantes", ou "ciclos poéticos em movimento", diferentes em cada livro, embora circunscritos ao vocabulário insistente da poesia de Eugénio de Andrade.

Essa coletânea, organizada pela Portugália Editora, representa um recorte significativo para o estudo do que seria uma primeira fase da produção eugeniana, pois, conforme José Bento ${ }^{2}$, não se limita à reunião de volumes até então publicados, tratando-se, antes, de uma revisão, já que houve supressões e acréscimos de versos, bem como alterações na divisão dos poemas pertencentes aos seguintes sete livros: As mãos

\footnotetext{
${ }^{1}$ Em 21 ensaios sobre Eugénio de Andrade (Porto: Editorial Inova, 1971), vários críticos comentam esta questão. Para citar alguns exemplos, Mário Sacramento discorre: "Não sei se há outras obras (mas não o creio) que contenham, como esta, tanto em tão pouco. [...] Quase sem metáforas, a poesia de Eugénio de Andrade é uma só metáfora. Quase sem símbolos, um único símbolo. Quase sem duração, uma só duração", em “Quase sem...” (1971, p. 371). Também Alexandre Pinheiro Torres define o vocabulário eugeniano como "reduzido e conhecido. Vem dos Cancioneiros. Mas saca dele as últimas virtualidades". (1971, p. 18). E Fernando Mendonça: "Ao longo de toda a obra do autor de Coração do dia existe uma repetição de nomes que permanecem como palavras-chaves, pois nelas se fecha o seu universo poético." (1971, p. 111). E ainda Óscar Lopes: "Nós poderíamos encarar toda a poesia de Eugénio de Andrade como uma permanente hipálage, a operar de um modo sobriamente clássico com um mínimo limpo e eficaz de imagens" (1971, p. 420).

${ }^{2}$ Também em "Poemas de Eugénio de Andrade". 21 ensaios sobre Eugénio de Andrade. Porto: Editorial Inova, 1971, p. 268. Outra indicação importante para a possível classificação dessa coletânea como "primeira fase" da poesia eugeniana é a observação de Gastão Cruz, que, ao se referir a Obscuro domínio, livro imediatamente posterior a Poemas, identifica transformações estilísticas e a "formulação de uma arte poética diversa, específica novidade" em relação aos livros anteriores, em "Função e justificação da metáfora na poesia de Eugénio de Andrade", idem, p. 130. Por fim, Jorge de Sena também contribuiu para essa delimitação: após comparar a primeira edição de As mãos e os frutos de 1948 com a edição presente em Poemas, concluiu que cerca de $40 \%$ das composições sofreram mudanças, o que evidencia o caráter de revisão e delimitação mais definitiva por parte do poeta em relação à sua obra, em "Observações sobre As mãos e os frutos", idem, p. 268. Ao definir este que seria um momento primeiro de sua poesia, Eugénio também optou por não incluir seus três primeiros títulos, escritos durante a juventude, conforme explicamos acima, no corpo do texto.
} 
e os frutos (1948), Os amantes sem dinheiro (1950), As palavras interditas (1951), Até amanhã (1956), Coração do dia (1958), Mar de setembro (1961) e Ostinato rigore (1964), estabelecendo, com isso, forma mais definitiva para a obra até então publicada ${ }^{3}$. Seus primeiros títulos - Narciso (1940), Adolescente (1942) e Pureza (1945) -, escritos durante a juventude, foram renunciados e excluídos dessa primeira reunião de sua obra, publicada em 1966.

Sem descartar a ressalva de Eduardo Prado Coelho de que "cada poema é uma força-forma determinada por uma intencionalidade que estrutura os seus diversos elementos" ${ }^{4}$, cujo sentido final não se depreende necessariamente do cotejo com outros poemas, o procedimento de repetição dos termos também confere aos poemas eugenianos uma dinâmica mais global, que atravessa determinadas tensões sem que se desfaça cada unidade poemática - "força-forma" sempre independente e radiante de sentido. O recorte proposto pretende, portanto, respeitar o constante regresso implícito ou explícito dos signos e das imagens, que, refletindo todos os demais, adia os sentidos para uma leitura que se quer cada vez mais ampla e total, e transpõe, como pretendemos provar, os elementos e os temas da poesia eugeniana para a problemática geral da arte poética.

Assim, se em cada um dos livros a poesia eugeniana percorre o que parece ser ímpetos cíclicos e repetitivos, como que a narrar, por exemplo, desde o nascimento da palavra - ocorrida, muitas vezes, de um "rumor" pressentido no silêncio, ou afirmada em consonância com as estações do ano, com o ciclo vital dos frutos e das sementes até seu desgaste e esterilidade, em uma análise do conjunto os "ciclos" se revelam abertos e ondulantes, prescrevem modulações de sentido, movimento de expansão e abertura, e a escrita eugeniana desponta em seu caráter mais errante, instável e autorreflexivo.

O desdobrar das imagens e a movimentação dos signos principais ${ }^{5}$ inserem a poesia de Eugénio em uma concepção poética que se apresenta em processo de mutação

\footnotetext{
${ }^{3}$ Não é nosso intuito comparar as edições anteriores a fim de investigar a fundo as alterações realizadas para a edição da Portugália Editora. Embora tal cotejo seja necessário, ele não será o foco de nossa pesquisa.

${ }^{4}$ Nosso critério é citar em nota os títulos das obras e seus respectivos autores apenas quando aparecem pela primeira vez em cada capítulo. Nas ocorrências seguintes, referimos o nome do autor, a data e a página entre parênteses, no corpo do texto, conforme exigido pelas normas da ABNT. O ensaio de Eduardo Prado Coelho intitula-se "Relatório duma leitura da poesia de Eugénio de Andrade, e do prazer que ela provoca no leitor”. 21 ensaios sobre Eugénio de Andrade. Porto: Editorial Inova,1971, p. 82.

${ }^{5}$ Mais adiante, no próprio corpo do texto, oferecemos uma justificativa para a escolha dos termos "signo"
} 
constante, cujos gestos demonstram o esforço quase desesperado ante um esgotamento que se pressente iminente. Nesse contexto, o eu lírico eugeniano posiciona-se a igual distância da vontade de afirmação da linguagem poética e do sentimento de negação que sobrevêm de suas frágeis possibilidades de resistência ao processo de "desumanização" percebido em tantos aspectos do mundo moderno.

De início, analisamos o texto de introdução da coletânea, intitulado "Poética", que apresenta algumas das coordenadas principais da poesia eugeniana. Em seguida, conferimos ênfase ao estudo do prefácio (quando há) e do poema de abertura de cada livro. Em alguns volumes há ainda o poema com título homônimo ao do livro, que por vezes (nem sempre) coincide com o poema de abertura. Juntos, oferecem pontos de partida para a identificação dos principais signos e ciclos temáticos desenvolvidos em cada livro. A revisão proposta por Eugénio de Andrade dessa primeira fase de sua obra torna mais evidente a unidade de composição entre os poemas, em que se privilegiam a ordem e a intersecção dos mesmos ao longo dos volumes. ${ }^{6}$ Assim, o poema de abertura, quando não leva o mesmo título do livro, apresenta já aquele que identificamos como signo principal ou insere-se, ainda, nas unidades de tom e de inspiração reconhecíveis em todo o livro. A seleção dos demais poemas e trechos decorre da leitura crítica de tais "unidades ondulantes", com o propósito de verificar o princípio construtivo e o caráter reflexivo da poesia eugeniana. Nosso objetivo principal é investigar a concepção poética eugeniana, formulada (e reformulada) no percurso (ainda que instável) dos diversos núcleos organizados ao redor dos signos postos "em rotação", para tomar emprestada a expressão de Octavio Paz.

O pensamento de Octavio Paz sobre a poesia moderna, desenvolvido não só no ensaio "Os signos em rotação", mas em estudos mais amplos como $O$ arco e a lira e $O s$ filhos do barro $^{7}$, revela-se bastante pertinente para o entendimento da dinâmica fluida da poesia de Eugénio de Andrade. Na esteira de diversos críticos que descrevem o

\footnotetext{
e "imagem" ao nos referirmos ao léxico recorrente da poesia de Eugénio de Andrade.

${ }^{6}$ Jorge de Sena, ao comparar a primeira edição de As mãos e os frutos, de 1948, com a edição presente em Poemas, comprova a "unidade de tom" desse primeiro livro, já que Eugénio de Andrade teria revisado apenas duas sequências de poemas do livro, deixando o restante praticamente intocado, o que indicaria a existência de "aparentamento expressivo entre os poemas de certos grupos (ou de idênticas memórias quiçá subconscientes da sua composição), para lá da unidade de tom que é sem dúvida uma das razões do sucesso da colectânea". Em "Observações sobre As mãos e os frutos". 21 ensaios sobre Eugênio de Andrade. Editorial Inova Porto, 1971, p. 268. O próprio Eugénio de Andrade também revelou a existência de uma "unidade poemática" em cada um dos sete livros da coletânea, na entrevista "Da palavra ao silêncio", recolhida em Rosto precário. Vila da Maia: Imprensa Nacional, 1980, p. 302.

${ }^{7}$ O arco e a lira. Trad. Olga Savary. Rio de Janeiro: Nova Fronteira, 1982; Os filhos do barro. Trad. Olga Savary. Rio de Janeiro: Nova Fronteira, 1984.
} 
período moderno em termos de crise e desagregação ${ }^{8}$, Paz identifica algumas das circunstâncias com que se defrontam os poetas modernos ${ }^{9}$, as quais, muito resumidamente, apresentamos aqui como "perda da imagem do mundo", "aparecimento de um vocabulário universal, composto de signos ativos: a técnica" e "crise dos significados" (PAZ, 1982, p. 317). Assim, como "luzes que brilham e apagam sucessivamente" (PAZ, 1982, p. 345), os "signos" estariam a girar, no poema moderno, em busca de um significado:

[...] Quem sabe como será realmente o que vem e qual é a imagem que se forma num mundo que, pela primeira vez, tem consciência de ser um equilíbrio instável flutuando em pleno infinito, um acidente entre as inumeráveis possibilidades de energia? Escritura num espaço cambiante, palavra no ar ou na página, o poema é um conjunto de signos que buscam um significado. [...] Não uma forma, mas signos que se projetam num espaço animado e que possuem múltiplos significados possíveis. $\mathrm{O}$ significado final desses signos o poeta ainda

\footnotetext{
${ }^{8}$ À concepção do moderno é comum encontrarmos associadas, em grande parte da tradição de autores que sobre ela formularam juízos, as noções de "paradoxo" e "vivência de crise". Nesse sentido, foi na modernidade que se criou o espaço dificultoso entre sujeito e mundo, em que se conheceu a experiência de perda e fragilidade ontológica. Como mais tarde formulou Marshall Berman, em Tudo que é sólido desmancha no ar, a modernidade caracteriza-se por um conjunto de experiências "vitais" e contraditórias "de tempo e espaço, de si mesmo e dos outros" que prometem, ambos, aventura e risco, levam tanto à destruição quanto à construção, e acarretam sentimentos antagônicos: "O turbilhão da vida moderna tem sido alimentado por diversas fontes: grandes descobertas nas ciências físicas, com a mudança da nossa imagem do universo e do lugar que ocupamos nele; a industrialização da produção, que transforma conhecimento científico em tecnologia, cria novos ambientes humanos e destrói os antigos, acelera o próprio ritmo da vida, gera novas formas de poder corporativo e de luta de classes; descomunal explosão demográfica, que penaliza milhões de pessoas arrancadas de seu hábitat ancestral, empurrando-as pelos caminhos do mundo em direção a novas vidas; rápido e catastrófico crescimento urbano; sistemas de comunicação de massa [...], um mercado capitalista mundial, drasticamente flutuante, em permanente expansão" (BERMAN, 1992, p. 16). Após a separação entre homem e natureza, o fracasso do transcendente, a "morte de Deus", dissolveram-se as verdades, e, com elas, o senso de identidade e a unidade de consciência. A esse problema, articulamos a "crise de representação" decorrida da mudança epistemológica apontada por Gumbrecht, em que se deu "a perda de confiança no conhecimento produzido pelo observador de primeira ordem". Ou seja, crise também acarretada pela distância do posicionamento crítico e pela "instabilidade do campo hermenêutico, visto que cada descrição do mundo é, sobretudo, uma redescrição, cujos limites e condições são então constitutivamente provisórios”. Apud Helena Carvalhão Buescu. Dicionário de Fernando Pessoa e do modernismo português. Org. Fernando Cabral Martins. Caminho, Lisboa: 2008, pp. 468 e 469.

9 Embora a "modernidade" possa ser traçada desde o período dos descobrimentos no século XV, em diversas ondas ou "cascatas", como definiu Gumbrecht (apud BUESCU, 2008, p. 468), a modernidade aqui tratada corresponde ao período iniciado em meados do século XVIII, cujas transformações sociais e espirituais ocasionaram uma "nova visão de mundo" que se prolonga até os tempos atuais. Para Octavio Paz, especificamente, embora a "modernidade" seja um híbrido histórico, ela "comienza como uma critica de la religión, la filosofia, la moral, el derecho, la historia, la economia y la política” (PAZ, 1994, p. 501). Nessa mesma linha, Paz define a tradição da poesia moderna do seguinte modo: "La tradición de la poesia moderna es uma tradición de rupturas sucesivas, aunque siempre acompañadas o seguidas de conjunciones, confluências y restauraciones. Doble movimiento: ruptura com la tradición prevaleciente y invención de outra tradición. Esas invenciones han sido resurrecciones de otros pueblos y culturas" (PAZ, 1994, p. 20).
} 
não os conhece: está no tempo, o tempo que fazemos entre todos e que a todos nos desfaz. [...] O poeta escuta o que o tempo diz ainda que ele diga: nada. Sobre as páginas algumas palavras se reúnem ou se dilaceram. Essa configuração é uma prefiguração: iminência da presença.

(PAZ, 1982, pp. 345 e 347)

Diante da desagregação do tempo e do espaço, da dissolução das verdades e dos significados permanentes, diante da expansão da consciência do "eu" e do enfraquecimento do "tu" no horizonte da comunicação, onde, conforme o crítico, a linguagem se viu ameaçada, a imaginação poética se defrontaria com o desafio de redescobrir o mundo como "presença" e relação de "outridade"10. De modo semelhante, na poesia eugeniana os signos se deslocam, se alternam, se repetem em constante procura - ora em expressão jubilosa das próprias potencialidades, ora em lamento e frustração ante o desgaste da linguagem poética.

No decorrer desse percurso crítico, a poesia eugeniana mobiliza palavras de teor autorreflexivo, ainda que nem sempre explícito, como acontece na poesia declaradamente metalinguística. A dinâmica dos poemas compõe, antes, ciclos ou fios narrativos que percorrem histórias de amor e aventura poética, e que se entrecruzam e se determinam em relação de coincidência. $\mathrm{O}$ mesmo ocorre com alguns dos outros temas presentes ao longo dos livros da coletânea, como o da natureza, o da relação materna, o do conflito entre indivíduo e sociedade, ou o da velhice: muitas vezes transpostos, mesmo que indiretamente, para o problema da arte poética ${ }^{11}$.

\footnotetext{
${ }^{10}$ Ao longo de $O$ arco e a lira, Octavio Paz oferece uma série de definições para "outridade", movimento através do qual a poesia manifestaria o desejo de romper a dualidade entre sujeito e objeto. Segundo o crítico, o poema é um dos poucos recursos que o homem tem para "ir além de si mesmo, ao encontro do que é profundo e original" (PAZ, 1982, p. 47). Ou seja, "A poesia coloca o homem fora de si e simultaneamente o faz regressar ao seu ser original: volta-o para si. O homem é sua imagem: ele mesmo e aquele outro" (PAZ, 1982, p. 138). Ou ainda: "A poesia é metamorfose, mudança, operação alquímica, e por isso confina com a magia, a religião e outras tentativas para transformar o homem e fazer 'deste' ou 'daquele' esse 'outro' que é ele mesmo" (PAZ, 1982, p. 138). A "outridade" se definiria, assim, como a vivência do "outro", ligada à estranheza, ao assombro de uma revelação, seja da presença do sagrado, em que se dá um esquecimento de si, culminando na sensação da unidade, seja da experiência do "ser" reconciliado: "O homem é inacabado, ainda que seja cabal em sua própria inconclusão; e por isso faz poemas, imagens nas quais se realiza e se acaba sem nunca se acabar de todo. Ele mesmo é um poema: é o ser sempre em perpétua possibilidade de ser completamente e cumprindo-se assim em seu não acabamento" (PAZ 1982, p. 328). A experiência da "outridade", que se constitui do cessar das dualidades, coincide com a vivência da "presença": "Recuperar a vida completa significa reunir a parelha vida-morte, reconquistar um no outro, o tu no eu, e assim descobrir a figura do mundo na dispersão de seus fragmentos" (PAZ, 1982, p. 329).

${ }^{11}$ Fernando Guimarães (A poesia contemporânea portuguesa. Vila Nova de Famalicão: Quasi Edições, 2002) afirma que praticamente todos os poetas das décadas de 1940 e 1950 (Eugénio de Andrade começou sua carreira no início da década de 1940) pensaram de modo explícito ou implícito os problemas
} 
Por conseguinte, ainda que Eugénio de Andrade alcance, por vezes, uma almejada "espontaneidade", em que sua palavra semelha a "um evento natural", como aponta Eucanaã Ferraz ${ }^{12}$, como se o poeta conseguisse criar uma linguagem própria pacificada dos "dramas intelectuais" ou dos "conflitos literários", com seus ideários estéticos estabelecidos por meio de lutas entre escolas e tendências (FERRAZ, 2004, p. 16), sua poesia não perde a consciência crítica de todo o processo, por vezes lamentada com lucidez pelo sujeito eugeniano:

A criação exige a vigília. Permanecer acordado, porém, impede a dissolução do sujeito na inconsciência da natureza. Assim, Eugénio de Andrade nos diz que toda escrita é fracasso, embora não haja nesta afirmação senão a consciência - uma consciência sem qualquer culpa ou amargura - de que há uma descontinuidade entre o poema e a natureza. [...] Mas há que pensar até que ponto a poesia de Eugénio, contrariando o que dela diz o seu criador, não terá incorporado o "esplendor" da integração do corpo com a natureza, confundindo então tais instâncias, habitualmente apartadas.

(FERRAZ, 2004, p. 19)

Em diversos momentos, a poesia eugeniana demonstra cumprir com plenitude a entrega ao "outro", seja à natureza, ao amante, seja à figura materna. Recorre a temas universais e atemporais por meio de uma "linguagem primordial", isto é, espécie de linguagem decantada que, ao mimetizar o primeiro contato com fenômenos naturais e com elementos fundamentais, procura reverter o processo de expansão da consciência individual, aproximando-se das raízes intuitivas e arcaicas do homem, das estruturas mais ocultas da mente, fonte dos afetos e dos impulsos inconscientes - como acontecia também nos mitos, nas lendas, na lírica do tipo tradicional e anônima. No entanto, os poemas eugenianos jamais se desprendem, por outro lado, da consciência crítica moderna.

A busca por uma dada "pureza" manifesta também a tentativa consciente de desligamento dos discursos correntes e dos modos de vida padronizados que determinam cada vez mais as constâncias aborrecidas e burguesas do homem moderno.

estruturais da linguagem poética. Por isso, as tantas "perplexidades reflexivas" na poesia dessa geração. No primeiro capítulo de nossa dissertação trataremos dessa questão com mais detalhes, ao nos aproximarmos do contexto literário e histórico da poesia eugeniana.

${ }_{12}$ "A poesia de Eugénio de Andrade está entre as mais belas coisas produzidas pela natureza. [...] Com a língua de Eugénio passa-se uma outra coisa: a invenção parece ser "Natural". Isto: um objeto da cultura que se dá sob a forma de uma utópica espontaneidade absoluta". Cf. "Eugénio: animal amoroso". Revista Relâmpago. N. 15, Ano VIII, 10/2004, p. 16. 
Através do amor, da relação com a natureza, dos modos de sentir e pensar arcaicos, a poesia eugeniana manifesta a procura por alternativas em que o homem moderno possa experimentar novamente, no próprio ato poético, sua condição de inteireza - alcançada na relação com o mundo, na descoberta da "outridade", na tentativa de religação, no procedimento construtivo em que o ser se revela como possibilidade.

Para Octavio Paz, um dos grandes problemas da poesia moderna, mesmo quando voltada para o passado, em retomada dos temas e formas tradicionais, é procurar uma conjunção com a história e com a vida presente: "Poetizar a vida social, socializar a palavra poética. Transformação da sociedade em comunidade criadora, em poema vivo; e do poema em vida social, em imagem encarnada" (PAZ, 1982, p. 310). Nesse sentido, o poema moderno é sempre consciente de si mesmo; pensa a si mesmo, ainda que de modo implícito; investiga em que consiste o processo da criação, a fim de que possa, antes de tudo, ampliá-lo e devolver ao homem seu "rosto" já "oculto" e "desfigurado", como afirma o próprio Eugénio de Andrade, no prefácio "Poética":

[...] O homem do nosso futuro não nos interessa desfigurado. Este animal triste que nos habita há milhares de anos, cujas possibilidades estamos tão longe de conhecer, é o fruto de uma desfiguração - acção de uma cultura mais interessada em ocultar ao homem o seu rosto do que trazê-lo, belo e tenebroso, à luz limpa do dia.

(ANDRADE, 1966, p. 12)

No primeiro livro, As mãos e os frutos, analisamos os signos centrais "mãos" e "frutos" em relação aos temas do amor e do fazer poético. O amor aparece como motivação central da palavra, e o ponto de encontro entre o processo amoroso e o poético é frequentemente descrito desde a origem. Do "germinar" ao lento processo de "maturação" do fruto, perseguimos também o movimento de instauração e perda do universo paradisíaco, em que o sujeito procurava vivenciar a plenitude do amor e da poesia, mas se deparava, ao mesmo tempo, com a brevidade de ambos perante as condições humanas mais duradouras de isolamento e ausência. O segundo livro, Os amantes sem dinheiro, expõe ciclos em que o sujeito investiga o passado, sobretudo nos pontos em que ele configura uma identidade poética. Nesse sentido, a figura materna é elemento principal, que aparece desde o prefácio como aquela que inspirou no filho o dom das palavras e a necessidade de desfrutar o mundo. Com a passagem do tempo, no entanto, o sujeito lamenta o desgaste dessa relação, principalmente como influência 
sobre o cantar poético. Certos poemas irão, assim, demonstrar esforços de transfigurar a ausência e a angústia, principalmente com o propósito de renovar os processos constituintes da poesia e mantê-los atuantes, acima da própria corrosão do tempo. Com isso, aspira-se a uma unidade mítica que ao longo do livro será contemplada no arquétipo da mãe, topos da união com o cosmos e da comunhão primordial com o mundo. Ao mesmo tempo, porém, há o reconhecimento crítico e doloroso de que toda unidade só pode ser provisória. O trabalho contínuo de transubstanciação que a poesia eugeniana realiza da própria sensação de perda do instante - frequentemente agregada à dor da separação da mãe - revela-se em imagens fugidias e evanescentes como a do "pássaro", que poderia aludir à substancialidade da poesia, mas também à sua natureza transitória e metamórfica. Assim como o "fruto" ou as "mãos" no livro anterior, a "ave" é elemento de mediação das profundas contradições vividas por essa poesia: entre o universo de plenitude e falta, entre o passado e o presente, entre o dizível e o indizível, entre a origem e o alcance da palavra poética.

Os signos analisados nos livros seguintes são, respectivamente, o "navio" em As palavras interditas, que se desloca pela cidade durante o que parece ser o período conturbado do pós-guerra em Portugal, em que o regime ditatorial de Salazar sofria redefinições; a "luz" ou "chama" em Até amanhã, onde se observa a exaltação da juventude e do tempo instantâneo do corpo, principalmente como resistência e confronto com o discurso histórico; a "água" em Coração do dia, ao redor da qual se reúnem as aspirações de vida e fecundidade de um sujeito silenciado pela dor e pelo abandono; o "mar" em Mar de setembro, livro em que a "água" adquire estatuto de destino e, como imagem arquetípica da origem e da expansão do ser, remete também ao movimento constante da poética eugeniana; e, por fim, o "verão", em Ostinato rigore, livro em que o ritmo da poesia eugeniana se aperfeiçoa, apresentando um recorte mais epigramático, com pausas mais intensas entre os versos, sugerindo, musicalmente, a presença do silêncio - campo do indizível; fusão contraditória entre entrega e superação da morte.

Para investigar o que acreditamos ser a constituição de uma "poética" ao longo da coletânea, tomamos, ainda que parcialmente, a definição do termo dado por Lubomír Dolezel em A poética ocidental: "conjunto de pressupostos, conceitos e métodos que progressivamente se vai construindo numa sólida abordagem à literatura", "através da 
constante revisão do seu sistema conceptual e dos princípios metodológicos". ${ }^{13}$ Assim, embora o crítico encare a "poética" sob uma perspectiva essencialmente teórica e científica, cujos postulados percorrem todo o pensamento ocidental desde Aristóteles, Leibniz, Goethe, Coleridge, aos estruturalistas no século XX, não descartamos a possibilidade de esses princípios serem cultivados e desenvolvidos também pela própria

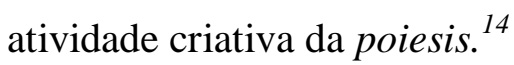

Como demonstra Eugénio de Andrade, o pensar sobre a poesia tornou-se inerente ao fazer poético, principalmente durante a "modernidade", cuja essência é caracterizada pela inovação e pelo constante "repensar, contestar, refazer ou recuperar a literatura anteriormente escrita" ${ }^{15}$. Além disso, a poesia portuguesa da década de 1940, período de estreia de nosso poeta, ainda inaugurou - conforme veremos mais adiante no próximo capítulo desta dissertação, em que pretendemos descrever o entorno históricoliterário de Poemas (1945-1965) -, um "novo ciclo de modernidade", em que novas sínteses eram buscadas para os impasses discutidos pelos movimentos portugueses de Presença e do Neorrealismo, principalmente em torno da natureza e função da literatura frente à "realidade" - considerada aqui em suas especificidades históricas, dentro do quadro de instabilidade e crise institucional do século XX.

A recuperação da autonomia do texto foi, de acordo com o crítico português Gastão Cruz, uma das reações mais significativas desta geração, cujo objetivo principal era abolir a usual cisão entre forma e conteúdo, e resgatar o poder reinstaurador da palavra, evidenciando, principalmente, o caráter inesgotável e independente da literatura diante do vínculo de obediência que lhe imputavam com o corpo social ou com as ideias e práticas políticas, principalmente em meio aos acontecimentos tumultuosos de quase meio século XX. A produção poética deste período pretendia salientar o poder de ambivalência da linguagem poética, capaz de alargar a consciência para os múltiplos sentidos da realidade. Através de certos procedimentos poéticos, sejam eles de “dispersão verbal de proveniência imaginária ou simbólica", como define Fernando

\footnotetext{
${ }^{13}$ A poética ocidental. Lisboa: Fundação Calouste Gulbenkian, 1990, pp. 19 e 21.

14 Embora examine a poética como "ciência da literatura", Dolezel faz a ressalva de que esta é uma "ciência prática", pois desde Aristóteles, que em sua Poética utilizou indiscriminadamente os termos ciência [epistème] e "arte" [technè], a diferenciação entre as duas não é geralmente aceite: "É importante notar que uma ciência produtiva - tal como uma ciência prática - estabelece uma relação especial com o seu domínio. O conhecimento adquirido por estas ciências pode ser usado como orientação para "agir" e para "fazer", respectivamente. Daí que a diferenciação entre uma ciência produtiva como a poética e a arte da poesia não implique uma separação entre as duas actividades” ( DOLEZEL, 1990, p. 31).

${ }^{15}$ Expressão de Gastão Cruz. A poesia portuguesa hoje. Lisboa: Plátano editora, 1973, p. 13.
} 
Guimarães ${ }^{16}$, ou ainda do movimento reflexivo do poema, em que se evidenciava o papel da linguagem poética, a fim de que o leitor pudesse também percorrê-la e vivenciá-la como espaço de criação e conhecimento, esses poetas buscavam modos de expansão e abertura imagética da linguagem, renovando o poder liberador da inspiração poética. Nesse contexto de "perplexidades reflexivas", como definiu Guimarães, Eugénio de Andrade submete sua poesia à constante indagação de sua própria natureza e efeitos.

Desse modo, a reflexão poética promovida por Eugénio de Andrade e realizada textualmente aborda a themata fundamental da poética ocidental descrita por Dolenzel: o conceito de literatura como estrutura; o problema da relação entre arte poética e mundo; o problema da criatividade poética e a reflexão sobre a linguagem. São essas as quatro questões principais pensadas pela poiesis eugeniana, por meios de referentes próprios, pertencentes a um universo poético cujos ciclos e coordenadas é nosso intuito apontar.

Por fim, pretendemos justificar, nesta introdução, a escolha de termos tão amplos quanto "signo" e "imagem" para designar nada mais que o léxico figurado e repetitivo dos poemas eugenianos - talvez de maneira mais inteligente, denominado simplesmente "palavras" pelo próprio Eugénio de Andrade, em "Poética". Em vários momentos, as palavras que designamos por um ou outro termo como "mãos" e "frutos", por exemplo, podem ser chamadas simultaneamente de "imagem" ou "signo", ainda mais se tomados em seu sentido mais lato, como na definição de Octavio Paz, que aplica "imagem" a praticamente "toda forma verbal, frase ou conjunto de frases, que o poeta diz e que, unidas, compõem um poema" (PAZ, 1982, p. 119); ou, conforme Antonio Candido, em $O$ estudo analítico do poema, que define "imagem" como "nome que damos a toda figuração de sentido que faz as palavras dizerem algo diferente de seu estrito valor semântico" (CANDIDO, 2006, p. 121); ou, ainda, no comentário de Stephen Reckert sobre o "signo" como veículo através do qual "o ser humano relacionase com o universo (que inclui, naturalmente, os outros seres humanos)" (RECKERT, 1996, p. 13) ${ }^{17}$; "veículo de um fenômeno qualquer de semiose", "parte integrante de um

\footnotetext{
${ }^{16}$ A poesia contemporânea portuguesa. V.N. Famalicão: Quasi edições, 2002, p. 9.

${ }^{17}$ Do cancioneiro de amigo. Stephen Reckert e Helder Macedo. Lisboa: Assírio \& Alvin, 1996.
} 
sistema, isto é, de um conjunto finito de elementos interdependentes que se delimitam reciprocamente, sendo sempre relativo o seu valor" ${ }^{\text {18. }}$.

Como em praticamente toda poesia, há nos poemas de Eugénio de Andrade um emprego variado de diversos tropos e figuras como metáforas, metonímias, símbolos, alegorias, anáforas, hipálages ${ }^{19}$, etc., cuja especificidade é por nós às vezes ressaltada, sobretudo em um primeiro momento da análise, quando partirmos de uma investigação mais pormenorizada dos poemas de abertura e dos poemas que levam o mesmo título do livro. No entanto, nosso foco e recorte pretendem privilegiar o estudo das recorrências como expressão da concepção poética mutável de Eugénio de Andrade, o que implica considerar, em uma ótica macrotextual, o jogo dinâmico entre os elementos, que parecem suspender o processo de referência dos termos particulares em proveito de um "esquema global das referências internas" 20 , compreendidas numa unidade menos linear e mais plurissignificativa.

Escolhemos designar, dessa maneira, o léxico repetitivo dessa poesia pelos conceitos mais gerais de "signo" e "imagem", sem deixar de considerar, contudo, o sentido mais restrito desses termos, ou seja, aquele historicamente motivado, que remete à tradição poética manifestada com ênfase ao longo da primeira metade do século XX (embora sua formação date de períodos anteriores) ${ }^{21}$, formada por diversos grupos e movimentos que procuraram romper, entre uma série de demandas, com a função referencial da literatura, ou com a visão mais "conteudística”, fundamentada na lógica

\footnotetext{
${ }^{18}$ Segundo o Dicionário de teoria da narrativa: "Objeto perceptível que funciona como substituto representativo de algo distinto dele mesmo, o signo é, pois, originalmente duplo, ao mesmo tempo marca e ausência. É no seio de um grupo definido de utentes, no interior do corpo social, que o signo se institui." Carlos Reis e Ana Cristina M. Lopes. São Paulo: Editora Ática, 1988, p. 136.

19 Eduardo Prado Coelho menciona alguns exemplos de estrutura anafórica na poesia de Eugénio de Andrade, no já citado artigo de 21 ensaios sobre Eugénio de Andrade (1971, p. 88). Óscar Lopes discorre em ensaio do mesmo livro: "Nós poderíamos encarar toda a poesia de Eugénio de Andrade como uma permanente hipálage, a operar de um modo sobriamente clássico com um mínimo limpo e eficaz de imagens" (1971, p. 420).

${ }^{20}$ Expressão de Frank Joseph, citada por José Maria de Souza Dantas, em Imagem poética, linguagens, modernidade. São Paulo: Difel, 1979, p. 59.

${ }^{21}$ Tradição que se associa à defesa da "autonomia da literatura", empreendida, pela primeira vez, por escritores do período romântico, conforme explica Benedito Nunes, em "A visão romântica", em $O$ Romantismo. Org. J. Guinsburg. São Paulo: Editora Perspectiva, 1978. Segundo o crítico, os pensadores do Romantismo propuseram a revisão das poéticas e dos preceitos clássicos em torno da arte e deslocaram o foco da relação clássica (de imitação) entre obra e natureza, para concentrarem-se na tríade artista, obra e natureza, alterando o estatuto da arte e a situação do poeta, familiares até os dias de hoje: "Por intermédio da visão romântica [...] é que surge [...] essa autonomia intelectual dilemática da consciência artística, ora cultivada em altivo isolamento, ora trazida a público, em cumprimento de um dever apostólico, de uma missão espontânea para com a arte [...]; e é nela que entramam a obra de arte e o estado do mundo, colocando aquela num permanente confronto com o real” (NUNES, 1978, p. 54).
} 
da mensagem 22 . Os termos "signo" e "imagem", portanto, nos parecem mais aptos por cumprirem com a simultaneidade exigida pela poesia eugeniana, entre os elementos externos e internos ao discurso; ao passo que os conceitos de "símbolo", "alegoria" e "metáfora" nos parecem menos reflexivos, por dependerem, talvez em um maior grau, de um referencial externo. É importante dizer, contudo, que, no caso da poesia eugeniana, embora a exploração das "imagens" e a rotação dos "signos" embaralhem e problematizem as relações usuais de referência, elas jamais são suspensas, o que implicaria a dissipação completa da mensagem. Por outro lado, os conceitos de "signos" e "imagens" conseguem remeter, em condição de simultaneidade, à lógica interna do texto.

Assim, ao levarmos em conta o caráter particular e histórico desses termos, no caso da "imagem" é preciso considerar, principalmente, aquele sentido estrito consolidado a partir das definições de André Breton no Manifesto do Surrealismo, em que a "imagem" passa a se configurar pelo seu poder reconciliador, que equilibra os opostos sem eliminá-los, desafiando o princípio geral da contradição ${ }^{23}$. Os surrealistas, alinhados à tradição das vanguardas do início do século $\mathrm{XX}^{24}$, opunham-se aos valores

\footnotetext{
${ }^{22}$ Eduardo Prado Coelho, no artigo já citado, observa que "uma das marcas essenciais da modernidade na obra de Eugénio de Andrade é a ruptura duma tradição representativa, em que o poema nos remetia para a representação duma realidade anterior ao próprio poema (embora por ele reelaborada, ornamentada ou intensificada). Ora, em Eugénio de Andrade o poema é, na sua admirável transparência, duma opacidade total: ele não permite que se veja através dele, porque continuamente nos afirma que tudo está nele. Não se trata de desvio de uma linha realista, porque só há verdadeiro realismo quando o 'real' não é objeto duma contemplação, mas 'resultado' duma prática de apropriação simbólica da matéria" (COELHO, 1971, p. 67). Óscar Lopes, em ensaio reunido no mesmo livro, também comenta: "Estas imagens [da poesia eugeniana] não evocam uma realidade previamente conhecida, pois que efectuam precisamente uma desarticulação em relações estavelmente conhecidas; abordamos com elas novos continentes do real, testemunhados por evidência da sensibilidade e surpreendidos na luz cruzada das palavras e das sensações tais como as vivemos mesmo sem dar por isso" (1971, p. 414).

${ }^{23}$ Descrevemos a definição de "imagem" de Pierre Reverdy, frequentemente citada também por Breton, desde o Manifesto do Surrealismo até o prefácio de sua última coletânea de poemas, Signe ascendant: "A imagem é uma criação pura do espírito. Ela não pode nascer de uma comparação, mas da aproximação de duas realidades mais ou menos afastadas. Quanto mais as relações das duas realidades aproximadas forem longínquas e justas, tanto mais a imagem será forte, mais força emotiva e realidade poética ela terá." André Breton. Manifestos do Surrealismo. Trad. Sergio Pachá. Rio de Janeiro: Nau Editoras, 2001, p. 35. ${ }^{24}$ Alguns dos manifestos futuristas de Marinetti, como o "Manifesto técnico da literatura futurista", de 1912, já propunham a "extensão e o aprofundamento das analogias", conforme explica Richard Humphreys (Futurismo. São Paulo: Cosac \& Naify, 1999, p. 39), antecipando, com isso, a concepção surrealista da imagem: "A analogia não é senão o amor profundo que aproxima coisas distantes, aparentemente diversas, e hostis". A mesma "consciência simultânea" se faz latente na concepção da escrita por parte dos Imagistas, movimento anterior à irrupção do surrealismo, fundado em 1910, principalmente pelo poeta americano Ezra Pound, e que muito influenciou também a poesia eugeniana. Pound procurava produzir o que denominava "One-image poem": poema estruturado ao redor de uma única e arrebatadora imagem dominante, seguida por uma sucessão ou justaposição de imagens relacionadas, cujo efeito maior é a sensação de instantaneidade, conforme explica o crítico William Pratt: "The plot or argument of older poetry is replaced by a single, dominant image, or a quick succession of
} 
racionalistas e cristãos da civilização, e tinham como projeto a transformação da realidade, conforme explica Octavio Paz, crítico que também escreveu sobre o movimento, em El surrealismo ${ }^{25}$. Segundo Paz, os surrealistas recusavam os dualismos da ciência, da religião cristã e da moral capitalista (que costuma classificar os objetos em "úteis" e "inúteis"), a fim de promover a intersecção entre o eu e o mundo, entre o subjetivo e o objetivo, o tempo e o espaço, o interior e o exterior, a vida e a morte, o real e o imaginário, o passado e o futuro etc. (PAZ, 1982, p. 41 e 45). Paz demonstra, nesse mesmo artigo, a associação da "imagem" com os mecanismos da "imaginação" (tida como faculdade produtora de imagens) e do "desejo": "Imaginar es ir más allá de sí mismo, proyectarse, contínuo transcenderse. Ser que imagina porque desea, el hombre es el ser capaz de transformar el universo entero en imagen de su deseo" (PAZ, 1982, p. 37). Ou seja, a "imagem", inspirada pelos mecanismos da imaginação, do desejo e também pelo princípio da analogia, associa-se à ideia de movimento e vir-a-ser contínuo - dinâmica em que se insere também outro comentário importante, do crítico francês Michael Riffaterre, sobre as imagens surrealistas: "obscuras, desconcertantes, e às vezes absurdas", mas nem sempre produções ligadas apenas ao inconsciente, conforme a atribuição geral da crítica. Riffaterre acentua que a maioria dos críticos estuda as imagens surrealistas isoladamente, enquanto elas só podem ser analisadas em conjunto, como uma verdadeira "cadeia de imagens" 26.

related images: its effect is meant to be instantaneous rather than cumulative" ("O enredo ou o argumento da poesia antiga é substituído pela imagem singular e dominante, ou pela rápida sucessão de imagens interrelacionadas: seu efeito é propositalmente instantâneo, antes de acumulativo". Tradução nossa). The imagist poem. Oregon: Story Line Press, 2001, p. 36. Acreditava-se que a imagem podia apresentar, na força de um único instante, todo um complexo intelectual e emocional, como definia Pound: "An image is that which presents an intellectual and emotional complex in an instant of time. [...] It is the presentation of such a complex instantaneously which gives the sense of sudden liberation; that sense of freedom from time limits and space limits; that sense of sudden growth, which we experience in the presence of the greatest works of art" ("Uma imagem é aquilo que apresenta um complexo intelectual e emocional em um instante do tempo. É a apresentação instantânea de tal complexo que oferece a sensação de repentina liberdade; aquela sensação de libertação dos limites do tempo e do espaço; ou aquela sensação de crescimento repentino, que experimentamos na presença das grandes obras de arte". Tradução nossa). Ezra Pound. "A few don'ts by an Imagiste", (Apud PRATT, 2001, p. 26). Assim, guardadas as diferenças, esses movimentos se aproximam e possuem um pano de fundo em comum: fundamentam-se na tradição experimental da poesia moderna, centrada no dinamismo e na simultaneidade da "imagem", que desponta em sua capacidade reconciliadora, conforme observamos também nesta descrição de Pound, anterior aos preceitos formulados por André Breton:"[...] The precise instant when a thing outward and objective transforms itself, or darts into a thing inward and subjective" ("O preciso momento em que algo externo e objetivo se transforma em algo interno e subjetivo" Tradução nossa). (PRATT, 2011, p. 37).

25 "La concepción surrealista no distingue entre el conocimento poético de la realidad y su transformación: conocer es un acto que transforma aquello que se conoce. La actividad poética vuelve a ser una operación mágica". El Surrealismo. Madrid: Taurus, 1982, p. 38.

${ }^{26}$ Citado por José Maria de Souza Dantas. Imagem poética, linguagens, modernidade. São Paulo: Difel, 1979, p. 29. Conforme explica o autor, Michael Riffaterre propõe o conceito de "metáfora filée", formado 
Os anos 1940 inauguraram o movimento surrealista português ${ }^{27}$, e assim como a poesia eugeniana, iniciada no início da década, boa parte da produção poética do período foi influenciada, direta ou indiretamente, pelos preceitos surrealistas. No caso da poesia eugeniana, a influência do surrealismo se inscreve, sobretudo, no tratamento dado ao amor ${ }^{28}$, visto como motivação da palavra poética, e no modo de exploração das imagens, inseridas em cadeias analógicas, encaradas como espaço alargado de coincidências e simultaneidades ${ }^{29}$.

No caso do "signo", também nos interessa o conceito dinâmico apresentado por Octavio Paz, no já citado "Signos em rotação", em que o termo é explicado em associação com a predominância da técnica no mundo moderno - "realidade poderosamente real", que passou a prevalecer ao longo da história da civilização ocidental sobre a realidade natural ou sobrenatural: "A indústria é nossa paisagem,

a partir de termos emprestados de The philosophy of rhetoric, de I.A. Richards, para estudar as imagens surrealistas: "Constitui um código especial, já que as imagens que a compõem não têm sentido, individualmente, como em grupo, a não ser em função da primeira entre elas. A primeira metáfora explica as seguintes, uma correlação com a outra, ocasionando, então, todo o sistema imagístico surrealista. Essas metáforas são ligadas entre si pela sintaxe, podendo fazer parte da mesma frase ou de uma mesma estrutura narrativa ou descritiva, cada uma exprimindo um aspecto particular de um todo, coisa ou conceito, que representa a primeira metáfora da série" (DANTAS, 1979, p. 29).

${ }^{27}$ Sobre a recepção do movimento surrealista em Portugal: Jorge de Sena e Adolfo Casais Monteiro publicaram, em 1944, no jornal $O$ Globo, uma página de apresentação do surrealismo com trechos traduzidos de André Breton, Paul Éluard, Benjamin Péret e Georges Hugnet. No fim da década de 1930, circulou em Portugal a antologia de poetas surrealistas organizada por Georges Hugnet. "O surrealismo em Portugal”. Estudos de literatura portuguesa III. Jorge de Sena. Lisboa: Edições 70, 2001, p. 240. Mesmo anteriormente à eclosão do Movimento Surrealista Português em 1947, portanto, podemos observar, já no começo da década de 1940, influências da poética surrealista em autores da geração de Eugénio de Andrade, como explica Jorge de Sena: "No fim dos anos vinte e trinta as actividades surrealistas como tal não tiveram repercussão, em Portugal, nos círculos de Vanguarda. Há que esperar até 1942, quando o meu primeiro livro de poemas apareceu, incluindo exemplos de escrita automática e escudado com epígrafes de alguns escritores surrealistas. Ao contrário do que foi erradamente escrito posteriormente, eu não fui nunca membro de nenhum dos grupos surrealistas surgidos em Portugal, e a minha aspiração como poeta (o que me levou a publicar em 1944 algumas traduções de textos surrealistas) não era ser um surrealista, mas alguém que escrevia depois do que as experiências surrealistas tinham vindo fazendo e dizendo". Em "O Surrealismo em Portugal". Estudos de literatura portuguesa III. Lisboa: Edições 70, 2001, p. 239. Eugénio de Andrade, ainda que se dissesse alheio a qualquer espírito de grupo, afirmava que sua poesia guardava "tonalidades" herdadas do surrealismo, "sobretudo em relação à pureza com que alguns surrealistas viveram a poesia". Em "Da palavra ao silêncio". Eugénio de Andrade poesia e prosa (1940-1979). Vila da Maia: Imprensa Nacional, 1980, p. 307. A respeito da influência do surrealismo sobre a poesia eugeniana, trataremos, mais especificamente, no primeiro capítulo desta dissertação, ao retratarmos o contexto histórico-literário de sua produção.

${ }^{28}$ Conforme explica Paz, o surrealismo buscou a identidade entre o amor e a poesia, e tal busca manifesta-se, sobretudo, na obra do poeta Paul Éluard (PAZ, 1982, p. 45) - poeta que Eugénio de Andrade reconhecidamente admirava, como podemos ler no trecho de uma entrevista: "Os grandes encontros são sempre encontros de juventude: Pessanha, Pessoa, Rimbaud, Lorca, Rilke e Éluard. [...] Foram estes, e não outros, por maiores que sejam, os poetas que encontrei na hora em que mais os necessitava". Eugénio de Andrade, na entrevista "Da palavra ao silêncio". Eugénio de Andrade poesia e prosa (1940-1979). Vila da Maia: Imprensa Nacional, 1980, p. 307.

${ }^{29}$ Por outro lado, a poesia eugeniana se afasta da poesia de tendência surrealista quando privilegia o rigor clássico e o acabamento das formas poemáticas. 
nosso céu e nosso inferno" (PAZ, 1982, p. 319). De acordo com o crítico, diante do fenômeno moderno da perda da imagem do mundo, o homem passou a enxergar a realidade sob a ótica da técnica, como "algo mais ou menos maleável para a vontade humana", ou seja, como "resistência", e não mais como um "arquétipo": "O saber da técnica aspira a substituir a realidade real por um universo de mecanismos" (PAZ, 1982, p. 320). Assim, se as obras do passado compunham-se de "símbolos", as obras modernas $^{30}$, como as construções da técnica em geral, contêm, predominantemente, "signos" que se erguem contra a ausência de uma "figura":

[...] São absolutamente reais, mas não são presenças; não representam: são signos da ação e não imagens do mundo. Entre elas [as construções da técnica] e a paisagem natural que as contêm não há diálogo nem correspondência. [...] Assim, a técnica não é propriamente uma linguagem, um sistema de significados permanentes fundados numa visão de mundo. É um repertório de signos que têm significados temporários e variáveis. [...] Seus signos não são uma linguagem: são os sinais que marcam as fronteiras, sempre em movimento, entre o homem e a realidade inexplorada. A técnica liberta a imaginação de toda mitologia e coloca-a frente ao desconhecido. Faz com que ela se defronte consigo mesma e, diante da ausência de toda imagem de mundo, leva-a a se configurar. Essa configuração é o poema. Fixado no informe, tal como os signos da técnica, e como eles em busca de um significado incessantemente elusivo, o poema é um espaço vazio mas carregado de iminência. Ainda não é presença: é um conjunto de signos que procuram seu significado e que não significam outra coisa além de ser procura.

(PAZ, 1982, p. 321 e 322)

Diante do "céu descoberto", o homem moderno viu-se impelido a reinventar-se. Sua natureza inacabada, "ser em perpétua possibilidade", conforme postula Paz, tornouse ainda mais evidente. Nesse contexto repleto de contradições, o poema moderno cumpre redescobrir a figura do mundo na própria "frenética imobilidade" e na dispersão dos fragmentos. Ou seja, em sua condição paradoxal o poema moderno utiliza o vocabulário da técnica, transformado em signos temporários, ao mesmo tempo que nega os mecanismos da técnica, em busca de uma imagem do mundo e de uma linguagem absoluta (refeita, mormente, na memória mítica das palavras), capaz de restituir ao homem sua inteireza.

\footnotetext{
30 "Modernas" aqui no sentido mais restrito, referente à tradição que se segue ao longo do século XX, tendo sido inaugurada, como aponta Paz, sobretudo a partir da obra de Mallarmé.
} 
Por conseguinte, os conceitos de "imagem" e "signo", dentro da tradição da poesia moderna, mobilizam ideias bastante paradoxais, como movimento, expansão, mas também repouso e simultaneidade. Conjugam a aceleração do tempo histórico e a profundidade do tempo mítico. Dentro da dinâmica dialética com que operam, apontam para uma dimensão metarreflexiva, cujos mecanismos deixam em evidência sua própria estrutura e configuração interna ${ }^{31}$.

No caso da poesia de Eugénio de Andrade, ambos remetem a uma cadeia de relações e coincidências, ao mesmo tempo que configuram movimento contínuo. Dentro da dinâmica particular dessa poesia, nossa proposta é diferenciar somente em grau as recorrências: chamamos de "signos" às imagens predominantes, que determinam o desenvolvimento de cada um dos ciclos apontados, e de "imagens" aos demais elementos recorrentes, que seguem compondo essa complexa rede em fabricação constante, que é a poesia de Eugénio de Andrade.

\footnotetext{
${ }^{31}$ Conforme ainda Paz: "A palavra poética não é menos 'materialista' que o futuro que ela anuncia: é movimento que gera movimento, ação que transmuta o mundo material. Animada pela mesma energia que move a história, é profecia e consumação efetiva, na vida real, dessa profecia. A palavra encarna, é poesia prática" (PAZ, 1982, p. 313).
} 


\title{
2. A POÉTICA EUGENIANA E ALGUMAS TENSÕES DA MODERNIDADE ESTÉTICA
}

\author{
Nas ruas, nos barcos, na cama, \\ com amor, com ódio, ao sol, à chuva, \\ de noite, de dia, triste, alegre - procuro-te! \\ (Eugénio de Andrade, 1966, p. 114)
}

Encerrar núcleos interpretativos, como propomos, dentro da circularidade de Poemas (1945-1965), edição revista e acabada dos sete títulos da primeira fase da trajetória de Eugénio de Andrade, não subtrai a dificuldade de captura de sentido que sua poesia geralmente impõe ao leitor. Conforme discorre Eduardo Prado Coelho, o leitor que se quer crítico depara com o desafio de analisar esta poesia, pois "tudo nela se liga e se corresponde" 32 como fios que se embaralham ao longo dos poemas e cujas pontas, que poderiam oferecer um começo para a análise, somem. Entrevemos, assim, na urdidura dos poemas, uma profusão de imagens e sons - "jogos de espelhos e de ecos" ${ }^{, 33}$ - que aproximam, cruzam e justapõem elementos aparentemente contrários, repetem-se em contextos inusitados e recompõem-se, deslocam significados anteriormente afixados:

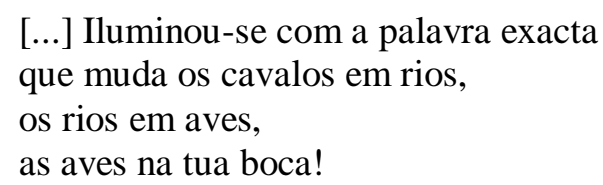

(ANDRADE, 1966, p.102)

A palavra é "exacta" quando atinge grau máximo de abertura e mobilidade. O "expresso" movimenta-se: nunca "existe definitivamente", mas "insiste, subsiste, flutua à superfície das coisas, no frágil equilíbrio que as separa das proposições" ${ }^{34}$, e se revela, como define Coelho, não como um "ser", nem como um "não-ser", mas como um “extra-ser”, ou seja, um "acontecimento". Em Eugénio de Andrade, cada poema é um "acontecimento de linguagem" 35 , um gesto de encontro e de coincidência, em que se dissolvem as fronteiras entre o sujeito e o mundo, entre as palavras e as coisas, entre os

\footnotetext{
32 "Relatório duma leitura da poesia de Eugénio de Andrade, e do prazer que ela provoca no leitor". 21 ensaios sobre Eugénio de Andrade. Porto: Editorial Inova, 1971, pp. 66 e 67.

${ }^{33}$ Expressão de Octavio Paz em "El surrealismo". El surrealismo. Org. Vitor García de La Concha. Madrid: Taurus, 1982, p. 37.

${ }^{34}$ Conforme a definição de Eduardo Prado Coelho, citando palavras de Deleuze (COELHO, 1971, p. 69).

${ }^{35}$ José Bento também utiliza a expressão em "Poemas de Eugénio de Andrade". Prefácio de 21 ensaios sobre Eugénio de Andrade. Porto: Editorial Inova, 1971, p. 307.
} 
modos de perceber o tempo e o espaço. Essa poesia, portanto, privilegia o interdito na tentativa de abolir os elos tradicionais e questionar toda referência.

Ao assimilar à própria escrita imagens em movimento, como o fluir de águas em "onde me levas, rio que cantei" ${ }^{36}$, ou "subterrâneo rio de palavras / me corre lento pelo corpo todo", corpo azul contra o meu corpo",38, ou ainda as "mãos" que "erguem-se abertas" pedindo "o seu destino de cavalo indomável como um rio" ${ }^{39}$, essa poesia incessantemente marca sua perpétua busca: "Fugitiva voz de água que se persegue" ${ }^{40}$. Segundo Gastão Cruz, a procura incansável que a poesia de Eugénio de Andrade invoca é principalmente motivada pelo amor ou pelo desejo, forças-formantes que mantêm as constantes transferências de um signo a outro e a proliferação de metáforas: só o amor é capaz de "gerar essa indistinção máxima das coisas que alimenta a metáfora". Conforme explica o crítico, "perseguir uma imagem é sempre, para o autor de Os amantes sem dinheiro, perseguir uma série de outras de que ela é a metáfora ou que são metáforas dela" (CRUZ, 1971, p. 123).

Entre os críticos que se surpreenderam diante das correspondências ou equivalências estabelecidas pela poesia de Eugénio de Andrade, citamos também Luís Miguel Nava, autor de $O$ essencial sobre Eugénio de Andrade, texto fundamental para nossa pesquisa. Nava identifica nessa poesia um "excesso" de "energia" ou "carga afetiva" que se concentra em certos "signos carregados", como "barco", "fonte", "ave", por exemplo, que "parecem transportar em si uma forte carga, geralmente positiva, que lhes confere um estatuto essencial e lhes permite ocuparem, em determinadas circunstâncias, o lugar das outras" (NAVA, 1987, p. 23). Assim, tudo corre como se passasse em dois planos: "O das evidências, no âmbito do qual determinadas relações se nos revelam aos sentidos, e o das essências, onde a afinidade entre as coisas efectivamente se decide" (NAVA, 1987, p. 27). Sendo assim, tudo aquilo que encontramos investido nessa poesia de certa "carga afetiva" pode estar agregado a um desses "signos carregados", como "barco", por exemplo: "Tudo se passa como se, à medida que nas coisas se fosse acumulando uma certa energia, elas se aproximassem da

\footnotetext{
${ }^{36}$ Do poema 30 de As mãos e os frutos (ANDRADE, 1966, p. 49).

${ }^{37}$ No poema "Surdo, subterrâneo rio...", em Os amantes sem dinheiro (ANDRADE, 1966, p. 89).

${ }^{38}$ No poema "Mar, mar e mar", em As palavras interditas (ANDRADE, 1966, p. 120).

39 Poema 16 de As mãos e os frutos (ANDRADE, 1966, p. 34).

${ }^{40}$ Expressão de Gastão Cruz. "Função e justificação da metáfora na poesia de Eugénio de Andrade". 21 ensaios sobre Eugénio de Andrade. Porto: Editorial Inova, 1971, pp. 117 a 130.
} 
essência dos barcos, para a qual todas tendessem de algum modo" (NAVA, 1987, p. 23).

O mesmo aconteceria, por exemplo, com o "signo carregado" da "fonte", que congrega uma energia suplementar, como se, além de designar outras coisas, pudesse também exprimir esse "excesso" de "energia" de que fala Nava e do qual muitas outras coisas também são portadoras. Dessa maneira, "a fonte impõe-se pelo que nela claramente aponta para a origem, da qual, na poesia de Eugénio de Andrade, decorre o excesso que o poeta busca em todas as coisas" (NAVA, 1987, p. 30). Logo, todas as coisas nessa poesia participam da essência da "fonte", ou da "essência das origens", que emana também de todos os outros signos recorrentes. Por conseguinte esses "signos carregados" evocam certa energia original, certa pureza ou "caráter essencial".

Não à toa a poesia de Eugénio de Andrade deixa pressentir uma série de correspondências ou equivalências para além das aparências com as quais nos habituamos a compor a realidade. Através dos poemas, divisamos um novo real, reinstaurado pelo estado de inocência que o fluir mágico da "fonte" desperta, signo de "espelho e transparência", conforme também o crítico Eduardo Lourenço, que "nos devolve nossa existência de cristal, verdadeira vida humana unida sem intervalo ao universo inteiro" ${ }^{41}$. Ao agregarem-se, portanto, os signos embaralham nossa capacidade analítica e nos revelam o mundo em estado de "essência" ou de "inocência", reapresentando-nos as sensações daquela "primeira primavera" em que as coisas nos apareciam suavemente indistintas. A intuição, a percepção e os sentidos sobrepõem-se ao domínio da lógica e da razão.

Por fim, Óscar Lopes também assinala as equivalências dessa poesia, mas sugere, contudo, que:

[...] quando as coisas deixam de ser coisas-coisas e passam a valer como coisas-sinais, não resta qualquer ambiguidade metafísica: entramos em pleno discurso paramusical onde as conversões recíprocas entre o silêncio e qualquer rumor arterial ou fluvial, entre a água e um ardor, entre a luz e a noite, entre a terra e o vento, através de todos os veículos de transição (a ave ou o pássaro, o barco, o dardo, a árvore, as espigas, os cabelos-raízes ou as folhas), onde todos esses sinais deixam de ser isoladamente significativos, deixam de ser unívocos um por um, pois as suas totalidades dinâmicas indigitam os novos significados únicos possíveis para cada caso ${ }^{42}$.

\footnotetext{
41 "A poesia de Eugênio de Andrade". 21 ensaios sobre Eugénio de Andrade. Porto: Editorial Inova, 1971, p. 32.

42 "Morte e ressurreição dos mitos na poesia de Eugénio de Andrade (Meditações quase em rondó)". Uma espécie de música - a poesia de Eugénio de Andrade. Lisboa: Campo das Letras, 2002, p. 39.
} 
Assim, as "totalidades dinâmicas" de que trata Lopes são movidas e organizadas por certos procedimentos poético-formais, os quais procuram agregar a imagética eugeniana em torno dos "signos recorrentes", formando "unidades interpretativas" ao longo da coletânea. No percurso instável desses "fios" ou "ciclos" significativos, investigamos a formulação de uma arte poética. Muitos poemas se apresentam como reflexão de seu próprio processo criador e gestativo, assim como do problema da palavra poética e de seus efeitos. Todavia, não descartamos a possibilidade de constante transformação de sua concepção poética, já que essa poesia não hesita em revelar também os desgastes de seus próprios mecanismos. A ênfase que ela parece ditar recai, antes de tudo, nos próprios processos de procura pela poesia, em que as "unidades" primordiais do poético são destacadas.

Desse modo, a imagética dos poemas eugenianos ergue o horizonte em que se faz a poesia: remonta às unidades elementares do poema e à sua gênese. Os versos dos poemas selecionados põem em evidência a malha das palavras, através do ritmo, sonoridade, metáforas, imagens e signos. O mergulho da poesia na poesia faz o leitor atentar para a natureza e função da linguagem poética. $O$ ato poético é assim intensificado. O leitor é capaz, através da recriação que o poema permite e da abertura a significações míticas, de vislumbrar sua mais profunda condição humana, ainda que tudo não passe de um frágil "acontecimento", a expressar aquilo que Nietzsche veio formular com a seguinte pergunta: “O que é a verdade? Resposta: um móvel exercício de metáforas". 43

\subsection{Entorno histórico-literário}

Assim como nos outros períodos de florescimento da arte moderna em Portugal $^{44}$, a década de 1940, em que Eugénio de Andrade estreava como poeta, representou um momento de crise e redefinição com o desenrolar da Segunda Guerra Mundial (1939-1945) e a autocracia cada vez mais rígida no país, imposta pelo regime

\footnotetext{
${ }^{43}$ Apud Roberto Calasso. A literatura e os deuses. São Paulo: Companhia das Letras, 2004, p. 131.

$44 \mathrm{O}$ florescimento da arte moderno-contemporânea em Portugal coincide com períodos de crises institucionais: o Futurismo e o Surrealismo, por exemplo, avançaram em períodos de guerras mundiais. Ambas as manifestações encontraram em Portugal uma sociedade assaz atrasada e resistente em relação às novas ideias e correntes estéticas que surgiam na Europa, embora também sedenta por mudanças, conforme explica José-Augusto França. A arte e a sociedade portuguesa no século XX. Lisboa: Livros Horizonte, 1991, p. 19.
} 
de António Salazar ${ }^{45}$, a fim de manter as políticas totalitárias e a "integridade africana", na contramão das ideias democráticas e anti-imperialistas difundidas no Ocidente a partir da vitória dos Aliados em 1945. Durante a década, o movimento surrealista também começava a delinear-se em Portugal, entre "persistências e mudanças", conforme explica Adelaide Ginga Tchen ${ }^{46}$, em meio às acomodações do pós-guerra que o regime promovia e seus primeiros sinais de crise, cada vez mais evidentes "nos anos 50 adentro" (TCHEN, 2001, p. 43).

$\mathrm{Na}$ verdade, desde a década de 1930 as vozes discordantes do regime se acentuavam, ou, mais especificamente, desde 1936, data de início da Guerra Civil Espanhola, que também contribuiu para consolidar o movimento politicamente engajado do Neorrealismo. Naquele período, logo após António Ferro ${ }^{47}$ ter assumido a presidência do Secretariado de Propaganda Nacional (SPN) para promover e institucionalizar uma arte moderna nacional financiada pelo Estado Novo, realizou-se o Salão dos Artistas Modernos Independentes, que impeliu Ferro a publicar diretrizes contestando os artistas que se "opunham à construção do estilo nacional" e "tendiam a formar da literatura e da arte mundos à parte, bastando-se a si próprios, tendo em si mesmos a finalidade e a razão de ser" (TCHEN, 2001, p. 49).

Na entrada da década de 1940, os sintomas de crise, a degradação econômica e política agudizavam-se, até que, em 1943, a queda de Mussolini e a derrota do Eixo trouxeram agitação e esperanças em Portugal. Se os anseios de liberdade não se cumpririam nos anos posteriores, com a manutenção de Salazar no governo e o prolongamento do regime por mais trinta anos, a forte cisão ocorrida na década de 1940, adensada pelo sentimento de descontinuidade entre Portugal e o resto da Europa, deixaria marcas profundas e contribuiria para a primeira penetração do surrealismo no

\footnotetext{
${ }^{45} \mathrm{O}$ regime ditatorial português é fundado com o golpe militar de 28 de maio de 1926 . António Oliveira Salazar, um professor de Economia, é nomeado ministro das Finanças em 1928. Com o êxito de sua "Reforma Orçamental", Salazar adquire popularidade e em 1932 assume a chefia do governo, fundando o "Estado Novo", respaldado na aprovação de uma nova Constituição, criada no modelo do Estado corporativo de Mussolini. Cf. The Making of Portuguese Democracy. Kenneth Maxwell. Cambridge: University Press, 1995, pp. 7 a 29, e “O Estado Novo: Salazarismo, Fascismo e Europa”. Luís Reis Torgal. História de Portugal. Org. José Tengarrinha. São Paulo: Editora da Unesp, 2001, pp. 391 a 415.

${ }^{46}$ A aventura surrealista. Lisboa: Edições Colibri, 2001, p. 43.

${ }^{47}$ Em 1930, Salazar cria o Secretariado de Propaganda Nacional (SPN) e nomeia António Ferro como presidente da instituição. Ferro, que sempre declarara sua admiração pelos fascismos emergentes, defendia a cooptação de artistas e escritores pelo Estado a fim de forjar uma "política do espírito" coerente e nacional, e organizou exposições oficiais, convidando expoentes da nova geração modernista portuguesa, tendo em vista a construção da "grande fachada de uma nacionalidade", conforme afirma Tchen, Idem, p. 48, e também divulgou a arte portuguesa por meio do rádio, cinema, teatro, música, publicações de brochuras, catálogos, etc.
} 
país, em 1940, com a exposição de António Pedro e António Dacosta: “Dacosta e Pedro denunciavam através de uma linguagem ousada e subversiva a realidade confrangente e angustiante de um momento histórico que não poderia ser ignorado" (TCHEN, 2001, p. 62). Se a exposição foi um eco isolado, por outro prisma ela possibilitou o alargamento do desejo de mudança, com a constatação do "predomínio de um modernismo oficial, frouxo, e 'adocicado' que o presencismo não conseguiria modificar” (TCHEN, 2001, p. 74), e despertou a intelectualidade portuguesa para a questão do papel interventor do artista na transformação da realidade e da humanidade.

Os futuros surrealistas aderiram ao "conteúdo humano" do movimento do Neorrealismo, mas essa ligação foi logo repensada, principalmente com a publicação do artigo "Como está a fazer-se a cultura da arte em Portugal", de Cândido Costa Pinto $^{48}$, em crítica à simplicidade do movimento neorrealista quanto à suposta conscientização promovida pela arte: "Este aceno à atenção é de natureza superficial e emotiva: excita, mas não esclarece nem transforma" (2001, p. 82). Assim, Costa Pinto opõe a esse "real aparente, exterior, visual", ao surréel, "o verdadeiro real, o que revela o homem e une cada indivíduo da nossa espécie ao todo" (2001, p. 82). As soluções ético-estéticas que os artistas e escritores surrealistas adotam a partir de então, defendidas oficialmente pelo grupo surrealista fundado em $1947^{49}$, influenciarão profundamente toda a arte portuguesa, abrindo caminho para outra interpretação do real e para uma nova descoberta do homem, agora visto também em sua dimensão subjetiva:

O Surrealismo registou uma pulverização incontestavelmente influente nos destinos artísticos e literários dos vários intelectuais que, a partir dos anos 50, vão inspirar-se nas referências surrealistas, consolidando historicamente a importância e o valor do surrealismo na cultura portuguesa.

(TCHEN, 2001, p. 208)

Eugénio de Andrade não participou do movimento surrealista; contudo, em seus poemas também pressentimos os mesmos anseios pela procura do absoluto, do impossível, do "ponto gama" que obcecava os artistas surrealistas: espaço de reconciliação dos contrários, em que "a destruição plena se identifica com a construção

\footnotetext{
${ }^{48}$ Apud Tchen. A aventura surrealista. Lisboa: Edições Colibri, 2001, p. 82.

${ }^{49}$ Mário Cesariny Vasconcelos, Alexandre O’Neil, José Augusto França e os pintores António Pedro, Fernando Azevedo, António Domingues, António Dacosta, e Moniz Pereira são alguns dos nomes envolvidos.
} 
absoluta", e as distinções da vida consciente são abolidas, misturando-se sonho e vigília, consciente e inconsciente, subjetividade e objetividade ${ }^{50}$. A aspiração totalizante não era comum somente aos surrealistas - embora estes a tenham sistematizado de maneira mais coerente - mas também à grande maioria de escritores em atividade durante o período catastrófico da guerra e do pós-guerra, segundo os relatos de Jean-Paul Sartre, autor que vivenciou de perto todo o desenrolar dos infortúnios dessa geração:

A partir de 1930, a crise mundial, o surgimento do nazismo, os acontecimentos na China, a guerra civil espanhola nos abriram os olhos, pareceu-nos que o chão ia faltar debaixo de nossos pés e, de súbito, para nós também começou a grande escamoteação histórica.

(SARTRE, 2006, p. 157)

Havia um sentimento geral de que a vida de cada indivíduo estava sendo governada por forças obscuras e coletivas, cujos mínimos detalhes pareciam refletir a condição do mundo inteiro, segundo o autor. Em cada promessa se escondia uma face oculta da ameaça, numa "mistura amarga e ambígua de absoluto e transitório [...]. Cada presente que vivíamos com entusiasmo, como um absoluto, era atingido por uma morte secreta" (SARTRE, 1989, p. 158). Impelidos a saber se era possível continuar sendo homem em meio à guerra, já que o destino humano se colocava nas mãos de potências desumanas, como explica Sartre, esses escritores empenhavam-se em redescobrir o absoluto, em resistência à relativização do homem e da vida e à irreversibilidade da história:

[...] Como ela [nossa época] nos levou a atingir os nossos limites, direi que somos todos escritores metafísicos. Penso que muitos dentre nós recusariam essa denominação ou não a aceitariam sem reservas, mas isso decorre de um mal-entendido: a metafísica não é uma discussão estéril sobre noções abstratas que escapam à experiência, mas um esforço vivo para abranger, a partir de dentro, a condição humana em sua totalidade.

(SARTRE, 1989, p. 164)

Se Eugénio de Andrade não vivera a guerra de perto como seu contemporâneo Tomaz Kim, que fora estudar na Inglaterra e, de acordo com João Gaspar Simões, concretizou em sua obra a visão apocalíptica da guerra, equacionada pelo problema da

\footnotetext{
${ }^{50}$ Jean-Paul Sartre. "Situação do escritor em 1947”. Que é literatura? São Paulo: Editora Ática, 1989, p. 146.
} 
responsabilidade do indivíduo perante os destinos coletivos do homem ${ }^{51}$, a poesia eugeniana também se inscreve nos extremos vividos no período e transita entre o que Sartre denominou de "absoluto metafísico e relatividade do fato histórico" (SARTRE, 2006, p. 159), polarizando-se entre os sentimentos de plenitude e de ausência, aspirando à reconciliação e afirmando-se como resistência à destruição e ao aniquilamento.

Ainda que Portugal não tenha visto de perto os bombardeios, sua população viveu a iminência da destruição, pois, até o final de 1943, o conflito ainda não se definira e a "neutralidade colaborante" de Salazar por pouco não sofrera a invasão alemã, que cruzava os Pireneus em junho de $1940^{52}$. A tortura e a opressão também eram cotidianas em Portugal sob a ditadura salazariana, e nesse contexto de guerra e totalitarismo a poesia surge como recuperação do humano, cooptando princípios das mais diversas tendências, tanto de elementos modernos como da poesia antiga, nomeadamente símbolos tradicionais, imagens arquetípicas, a visão mítica do mundo mas sempre reelaborando o mito para que nele pudesse conter uma reflexão sobre o seu próprio alcance e expressão na modernidade. À irreversibilidade do tempo histórico, portanto, apontada por Sartre na vivência da Geração de 30, Eugénio de Andrade responde com a reversibilidade do tempo poético, em que se procura a plenitude no trabalho com formações simbólicas tradicionais. O retorno à tradição pode, assim, ser visto como um ato de resistência, em que o poeta intenta entrar em contato com perspectivas e vivências anteriores ao presente de crise do homem moderno e anteriores também aos padrões burgueses e individualistas. Sua poesia oferece uma ordem diversa, em que a palavra procura restabelecer uma unidade entre homem, linguagem e mundo:

\section{Nocturno de Fão}

De palavra em palavra

a noite sobe

aos ramos mais altos

\footnotetext{
${ }^{51}$ Perspectiva histórica da literatura portuguesa (século XX). Porto: Brasília Editora, 1976, p. 386.

52 "O elemento determinantemente novo era, desde logo, a omnipresente ameaça da Alemanha hitleriana, com as suas divisões Panzer estacionadas nos Pirinéus, desde junho de 1940, a aguardarem luz verde para a 'Operação Félix' [invasão a Portugal]. Rodeada de uma aura de invencibilidade que só a resistência soviética de fins de 1941 começaria a questionar, a Alemanha ia crescendo de tom nas suas pressões sobre o governo de Lisboa, pressões que fez secundar, a partir de janeiro de 1941, com vários ataques à frota mercante e pesqueira portuguesa." José Mattoso. História de Portugal. Lisboa: Editorial Estampa, 1995 , p. 306.
} 
e canta

o êxtase do dia.

(ANDRADE, 1966, p. 224)

\subsection{Anos de "combustão verbal"}

“O acto poético é o empenho total do ser para a sua revelação. Este fogo de conhecimento que é também fogo de amor, em que o poeta se exalta e consome, é a sua moral. E não há outra" (ANDRADE, 1966, p. 9). Essa formulação feita por Eugénio de Andrade no pórtico de Poemas (1945-1965) inscreve sua poética na concepção de poesia que se afirma a partir dos anos 1940 em Portugal, período em que circulou a revista Cadernos de Poesia (1940-1953), para a qual também colaboraram, ao lado do poeta, Sophia de Mello Breyner Andresen, Tomaz Kim, Ruy Cinatti e Jorge de Sena.

Embora Sena contrarie certa leitura crítica que procurou agrupar escritores em torno de princípios estético-literários definidos pelos Cadernos de Poesia - segundo o autor, nada havia que pudesse irmaná-los ou aglutiná-los em um grupo - é inegável que os Cadernos contribuíram para divulgar o novo entendimento da poesia que se formava a partir da década de 1940, ainda que ele mesmo fosse assaz abrangente. Conforme admite o próprio Jorge de Sena ${ }^{53}$, poeta que colaborou ativamente na organização dos fascículos - publicados dessa maneira para iludir a censura do regime salazarista, que, no início da década de 1940, já não aprovava novos periódicos e submetia a rígido controle os já existentes -, os Cadernos concorreram para que se instituíssem novas perspectivas em relação à poesia portuguesa, subjugada até então pela "polêmica estéril" entre "presencistas" e "neorrealistas", "categorias cômodas para o culturalismo polémico e para a catalogação literária", para a qual "haverá evidentemente muitas poesias", conforme indicava a prosa de abertura da segunda série dos Cadernos, em $1951^{54}$.

\footnotetext{
${ }^{53}$ Em dois ensaios, Jorge de Sena oferece uma análise minuciosa sobre a revista: "Os Cadernos de Poesia". Estudos de Literatura Portuguesa I. Lisboa: Edições 70, 2001, pp. 261 a 267; e "Cadernos de Poesia". Estudos de Literatura Portuguesa III. Lisboa: Edições 70, 2001, pp. 203 a 205. Em "Eugénio de Andrade", Sena trata da relação entre o poeta e os Cadernos. Idem, pp. 169 a 171.

${ }^{54}$ Texto de abertura elaborado em conjunto pelos organizadores da segunda série: Ruy Cinatti, José Blanc de Portugal, José-Augusto França e Jorge de Sena, em "Os Cadernos de Poesia". Estudos de Literatura Portuguesa I. Jorge de Sena, Lisboa: Edições 70, 2001, p. 264. Conforme demonstra Sena, as três séries, a primeira publicada entre 1940-1942 e as duas últimas entre 1951 e 1952, reiteram os mesmos objetivos e princípios, embora seus idealizadores tenham se reorganizado entre uma série e outra. "Cadernos de
} 
Os Cadernos de Poesia procuravam divulgar uma produção bastante eclética, com o intuito de fazer sobressair, antes de tudo, o que havia de comum entre tanta diversidade, como traduzia o emblema "A Poesia é só uma" impresso no interior da capa que acompanhava cada edição. $\mathrm{O}$ que se solicitava, portanto, era o respeito à própria verdade da poesia e à essência do ímpeto poético, sempre livre do subjugo a filiações ou ideologias e do malogro dos critérios extraliterários, que reduziam a natureza do fenômeno poético, revelando-se incapazes de demonstrar que a poesia é "sempre muito mais", conforme defendiam seus principais teorizadores (ROSA, 1962, p. 21).

Desse modo, os Cadernos contribuíam para que se cumprisse um novo entendimento da poesia por parte do leitor, aberto às várias possibilidades que a poesia podia mobilizar, sem a necessidade de compreendê-la por meio de classificações ou relações que lhe tolhessem o caráter abrangente, conforme atesta, novamente, o texto que abre a segunda série: "[...] Para uma consciência que dialecticamente transcenda o momento que vive, não pode a poesia senão ser o que é: as obras significativas" ${ }^{\text {. }}$. Assim, os Cadernos propunham, desde seu início em 1940, um repositório antológico, publicando nomes de diversas tendências e idades, ligados tanto a Orpheu e a Presença - a exemplo de Luís de Montalvor e José Régio - quanto ao Neorrealismo - como José Gomes Ferreira - e ainda poetas estreantes que não pertenciam a nenhum movimento literário, como é o caso de Sophia de Mello Breyner Andresen e do próprio Eugénio de Andrade, o qual se dizia alheio a qualquer espírito de grupo ${ }^{56}$.

Embora se opusessem aos radicalismos e às categorias redutoras da poesia, os Cadernos não deixaram de cooptar, por outro lado, princípios defendidos tanto por autores de Presença quanto do Neorrealismo, como podemos verificar no mesmo texto de abertura da segunda série:

A expressão poética, com todos os seus ingredientes, recursos, apelos aos sentidos, resulta de um compromisso firmado entre um ser humano e o seu tempo, entre uma personalidade e uma consciência sensível do mundo, que mutuamente se definem ${ }^{57}$.

\footnotetext{
Poesia”. Estudos de Literatura Portuguesa III. Lisboa: Edições 70, 2001, p. 204.

${ }_{55}$ Texto de abertura da segunda série, em "Os Cadernos de Poesia". Estudos de Literatura Portuguesa I. Jorge de Sena. Lisboa: Edições 70, 2001, p. 264.

56 "Nunca fiz parte de nenhum grupo. Acaso ou desinteresse? Seja como for, é um espírito que me é alheio, esse de grupo." Eugénio de Andrade, na entrevista "Da palavra ao silêncio". Antologia Breve. Porto: Editorial Inova, 1972, p. 88

${ }^{57}$ Jorge de Sena em "Os Cadernos de Poesia". Estudos de Literatura Portuguesa I. Lisboa: Edições 70, 2001, p. 264.
} 
A "generosa exibição antológica" dos Cadernos, segundo expressão de Sena, não excluía nenhum autor, mas procurava, antes, salvaguardar a riqueza e a multiplicidade da poesia portuguesa, reunida por critérios de qualidade poética, independentemente das posições religiosas ou políticas de seus colaboradores. Requeriam uma plataforma ética antes de estética, por meio de um compromisso inseparável da consciência da dignidade humana (SENA, 2001, p. 267), ainda que livre de quaisquer idealismos, moral ou militância. Entendemos, por isso, que, mesmo não havendo um grupo em torno dos fascículos, nem orientações estéticas definidas, conforme defende Sena, é provável que os Cadernos tenham contribuído para fundar novas perspectivas para a poesia portuguesa.

Sena também critica a associação que frequentemente se estabelece entre Eugénio de Andrade e os Cadernos, em razão de o poeta não ter escrito em uma linguagem partidária, de intervencionismo sociopolítico, quando, de fato, sua contribuição poética se deu somente em um número da revista ${ }^{58}$, assim como muitos dos demais poetas que ali colaboraram. Porém acreditamos que a identificação do poeta com os Cadernos de Poesia não é infundada, já que, pelo fato de não ter se filiado a nenhum grupo e movimento - afirmando-se sempre à margem, sem deixar de catalisar em sua obra elementos das mais diversificadas tendências -, e tendo antes procurado, assim como muitos jovens de sua geração, um aprofundamento estético da linguagem, rumo a uma "remordenização dela, tal como fizeram também, por outras vias, os poetas ligados ao surrealismo" (SENA, 2001, p. 170), é possível constatar continuidades entre sua poesia e os empenhos de Cadernos de Poesia, definidos por Luís Adriano Carlos e Joana Matos Frias:

[...] Enquanto presencistas e neo-realistas reclamavam novos humanismos, os Cadernos vinham propor uma ética da comunicação estética capaz de reconhecer, sob as diferenças convencionais de superfície, a natureza da poesia e a poesia como natureza humana ou, numa fórmula de Jorge de Sena, como "expressão da variedade humana". Este radical sentimento estético do mundo e da vida iria unificar o percurso de toda uma geração que procurou integrar a consciência modernista da linguagem, menosprezada pelo NeoRealismo, numa consciência ética da poesia que os poetas de Orpheu

\footnotetext{
${ }^{58}$ Eugénio de Andrade publicou composições poéticas no n 5 da primeira série, em 1942, e depois contribuiu também, como afirma Sena, em 1953, para o $\mathrm{n}^{\circ} 13$ da terceira série, dedicada à memória de Teixeira de Pascoaes, mas dessa vez com "texto expressamente escrito", assim como António Pedro, Adolfo Casais Monteiro, Afonso Duarte, Eduardo Lourenço, Jacinto do Prado Coelho, Miguel Torga, José Régio, Óscar Lopes, Tomaz Kim, Sophia de Mello Breyner Andresen, José-Augusto França, Delfim Santos, Augusto Saraiva, etc. Idem, p. 266.
} 
jamais assumiram, por força do seu estoicismo abstrato e impassível perante os escombros da I Grande Guerra. ${ }^{59}$

A ligação entre Eugénio de Andrade e os Cadernos manifesta-se, em primeiro lugar, na defesa de uma poesia que pretende fundir ética e estética, e amalgamar, sem tomar partido, elementos das várias tendências da modernidade, evidenciando a pluralidade da poesia portuguesa, sempre em busca de uma expressão cada vez mais humana $^{60}$. A poesia de Eugénio de Andrade procurou também sagrar a atenção do público ao fenômeno poético, em conformidade com ideias presentes em ensaios publicados nos Cadernos, como "Contingências da Poesia", de João Pedro de Andrade, que apareceu no número 3 da primeira série, especificando os objetivos do "acto poético" e preconizando a arte como fim último, segundo aponta análise de Maria de Fátima Marinho Lisboa (1989) ${ }^{61}$ :

A separação da vida e da poesia imediatamente implica um apoucamento da primeira. Amputar da vida a poesia é conceber uma vida incompleta. [...] Poesia ao serviço da vida é uma fórmula acanhada e contraditória, em que um conceito total aparece submetido a um conceito parcial. [...] A classificação da poesia em social, metafísica, religiosa, mística ou subjectiva é inteiramente arbitrária. A raiz da poesia está na alma do poeta. Não é por um movimento voluntário e pré-determinado que ele canta este ou aquele motivo. Mas o poeta é um homem, que com a sua condição humana transporta crenças, dúvidas, ideais, certezas, e cujos entusiasmos, arroubos, desfalecimentos e lutas íntimas hão-de forçosamente vibrar na sua $\mathrm{voz}^{62}$.

\footnotetext{
${ }^{59}$ Texto de introdução de Cadernos de Poesia, reprodução fac-similar dirigida por Luís Adriano Carlos e Joana Matos Frias. Coleção Obras Clássicas da Literatura Portuguesa - Século XX. Porto: Campo das Letras, 2004, p. 10.

${ }^{60}$ Em trecho de uma das entrevistas reunidas em Rosto precário, Eugénio de Andrade é indagado sobre a "última geração de poetas" e o que o diferencia dos autores marcados pelo presencismo, neorrealismo e surrealismo, ao qual o poeta responde: "Confesso que tenho muita relutância em aceitar essas classificações. Os poetas de todos esses grupos dialogaram, foram sensíveis às posições várias uns dos outros, coexistiram num tempo sujo que a todos marcou. Como se sabe, alguns dos poetas mais lúdicos escreveram poemas de resistência, mais de um neo-realista foi fascinado pelo sortilégio do surrealismo, houve presencistas prolongados por neo-realistas, houve até quem começasse surrealista e acabasse neorealista. Muitos desses poetas foram contemporâneos uns dos outros, e as grandes diferenças que entre eles se possam encontrar terão sempre mais a ver com a qualidade de sua criação do que com os pressupostos teóricos de cada um". A posição de Eugénio de Andrade vai ao encontro das ideias defendidas pelos Cadernos de Poesia (em Rosto precário. Vila da Maia: Imprensa Nacional, 1980, pp. 334-335)

${ }^{61}$ A poesia portuguesa nos meados do século XX - rupturas e continuidades. Lisboa: Editorial Caminho, 1989 , p. 19.

${ }^{62}$ Citado por Fátima Marinho (Idem, Ibidem): Cadernos de Poesia. n 3, Lisboa, 1940, pp. 56-57.
} 
A poesia a partir de então tomava novos rumos: procurava evidenciar a especificidade da literatura, principalmente o papel da linguagem e sua dimensão simbólica e imaginativa. Em oposição às tendências do período, portanto, que se pautavam em torno da "querela" entre "arte pura", defendida pelos poetas de Presença, e "arte engajada", posição dos neorrealistas, essa nova geração de poetas, mais tarde associada também a tendências surrealistas, representou uma saída para a polêmica inaugurando um "novo ciclo de modernidade", que se fundamentava em um entendimento diverso da linguagem poética e de suas potencialidades intrínsecas, como se lê também em Gastão Cruz (1973) e Fernando Guimarães (2002), em seus estudos panorâmicos da poesia portuguesa ${ }^{63}$. Segundo Guimarães, praticamente todos os poetas das décadas de 1940 e 1950 pensaram de modo explícito ou implícito os problemas estruturais da linguagem poética. Por isso, as tantas "perplexidades reflexivas" dessa poesia e a ruptura com a tradição representativa, seja ela de ordem biográfica ou como retrato da personalidade do poeta, como queriam os poetas de Presença, seja de ordem sociopolítica, como a da literatura neorrealista.

De acordo com a nova perspectiva que se firmava, o poema não deveria carregar opiniões, crenças, ideias, mas sim tornar-se presente na exploração da linguagem ela própria, premissa fundamental para se compreender a condição humana de maneira talvez mais abrangente do que propunha a poesia de acento ideológico. O novo poema voltava-se, assim, para a realidade das palavras, em que se operavam aberturas, experimentações e renovações, possibilitando uma "espécie de nascimento"64 ao homem - ao encontro de si mesmo e do "verdadeiro real", para além da ótica social, já desgastada e deformante. Aos olhos dessa nova geração, somente como um ato em si poderia o poema ser fonte de conhecimento, expressão de um saber atuante tanto na realidade mais imediata - da vida política, histórica, social e individual do momento quanto no campo da existência mais ampla dos sentimentos, da psique e das significações míticas.

\footnotetext{
${ }^{63}$ Gastão Cruz. A poesia contemporânea hoje. Lisboa: Plátano Editora, 1973; Fernando Guimarães. A poesia contemporânea portuguesa. Vila Nova Famalicão: Quasi Edições, 2002; António José Saraiva e Óscar Lopes também procuraram demonstrar de que modo as tendências das décadas de 1940 e 1950 representavam uma contracorrente ao neorrealismo português, fundamentadas no princípio da autonomia da arte e da linguagem. História da Literatura Portuguesa. Porto: Porto Editora, 1955.

${ }^{64}$ Expressão de António Ramos Rosa. "Purificação no plano do ser e da linguagem". 21 ensaios sobre Eugénio de Andrade. Porto: Editorial Inova, 1971, p. 25.
} 
O fenômeno poético seria capaz de restituir ao homem a energia criadora, já desalentada pela excessiva racionalização e mecanização da vida moderna, e desse modo, ainda segundo esses autores, restaurar a grande aventura humana, traduzida no pleno exercício da liberdade e na perpétua procura de si mesma, circunstâncias capazes de levar o homem à transcendência de sua própria condição, cada vez mais frágil diante da vivência de crise e desagregação dos principais sistemas que constituem a sociedade e a cultura modernas.

Por conseguinte, os poetas pretendiam afirmar o valor histórico desta poesia na própria ruptura com a história, ou seja, na negação sistemática de todo o corpo de crenças e padrões que ditavam a experiência moderna, com o objetivo de instaurar no homem um solo novo, segundo afirma António Ramos Rosa, poeta que estreava na década de $1950^{65}$ :

A finalidade da poesia é estabelecer a integração imediata do homem no mundo através da combustão verbal, salvar o mundo e o homem no seu encontro e na sua unidade. Pela imaginação poética - e só por ela - todas as energias do universo ascendem à palavra [...]. A imagem poética moderna estabelece a unidade na multiplicidade, recupera a riqueza da percepção original nas suas várias significações, estabelece a identidade dos contrários, cria uma nova realidade, conservando, no entanto, cada termo concreto e independente [...]. A imagem poética cria o seu espaço, anulando a distância da significação representativa, impondo uma presença original. Palavra e objeto identificam-se. Nesse espaço, todos os encontros são possíveis e todo possível se torna real.

(ROSA, 1962, pp. 12, 13 e 15)

No poema "Espera", do primeiro livro da coletânea, Eugénio de Andrade aproxima elementos díspares ao longo de uma cadeia associativa de imagens que mimetiza o romper do discurso corrente para fazer nascer, na própria "mudez" das coisas, uma outra linguagem, mais profunda e mais totalizante. Esse poema apresenta, a nosso ver, uma espécie de súmula dos anseios principais dessa poesia, desdobrados e trabalhados em Poemas:

\footnotetext{
${ }^{65}$ António Ramos Rosa estreou como poeta em fins da década de 1950 (O grito claro, 1958) e, sob a influência marcante de poetas da década anterior, inclusive de Eugénio de Andrade, foi um dos principais teorizadores das novas visões que se formavam da poesia, sobretudo na esteira da "aventura surrealista" que se firmou em Portugal por volta de 1947. Cf. Poesia, liberdade livre. Lisboa: Livraria Morais Editora, 1962; e "Purificação no plano do ser e da linguagem". 21 ensaios sobre Eugénio de Andrade. Porto: Editorial Inova, 1971.
} 


\section{Espera}

Aqui onde o exílio

dói como agulhas fundas,

esperarei por ti

até que todas as coisas sejam mudas.

Até que uma pedra irrompa

E floresça.

Até que um pássaro me saia da garganta

E no silêncio desapareça.

(ANDRADE, 1966, p. 50)

O poema parte de uma situação inicial em que o sujeito lamenta o "exílio" de si mesmo e do mundo: "as coisas" ao redor se emudecem e o indivíduo enfrenta a condição dolorosa de isolamento e paralisia. Diante desse quadro, o sujeito poético procura pelo cantar - metaforizado na imagem "Até que um pássaro me saia da garganta" -, expressando esperança na chegada do "tu" e na linguagem poética como capazes de reinstituir a plenitude. Sua voz angustiada gradualmente consubstancia-se na linguagem do poema, posta em movimento, a tomar as rédeas na segunda estrofe, movendo os desejos, a percepção e a imaginação de modo a multiplicar metamorficamente as imagens.

O recurso da analogia e da aproximação de elementos díspares, como "pedra que floresce", também evoca o pensamento mágico e permite certo prolongamento mítico das palavras, restituindo a sensação de simultaneidade e de reversibilidade do tempo, por meio do nexo firmado entre coisas aparentemente longínquas. O cantar pretende reinstaurar a unidade perdida entre homem e mundo, mas a tentativa se revela frágil ao final do poema, com o retorno do "silêncio", destino que, embora bastante aspirado por essa poesia - a palavra poética em outro poema é referida como "morada do silêncio"66 -, aqui parece envolto em melancolia, o que poderia sugerir a temporariedade do canto e o retorno da condição de esterilidade inicial.

Nesse movimento circular, Eugénio de Andrade expõe ao leitor as etapas poéticas, a fim de incitá-lo a percorrer o espaço do poema e reconhecer suas forças latentes, as potencialidades infinitas do desejo e da imaginação que libertam o sujeito de sua existência confinada nos modos de vida e padrões sociais dominantes. O poeta

${ }^{66}$ Verso de Eugénio de Andrade citado por Luís Miguel Nava (1987, p. 51). 
procura revelar os materiais brutos do poético, aludidos pela metáfora da "pedra" que "irrompe" e "floresce", bem como as formas elementares do poema, refazendo os caminhos de sua própria gênese, desde suas motivações iniciais, como o impulso líricoamoroso, até o próprio trabalho das imagens.

\section{3 "Rostos do homem"}

Expressão de profundo lirismo, a poesia de Eugénio de Andrade mobiliza tradições de diversas fontes, não só de matrizes modernas, mas também de origens mais remotas, como a greco-romana, a lírica ibérica do tipo tradicional, a poesia oriental e outras tantas influências, ora apontadas pela crítica ${ }^{67}$, ora reconhecidas pelo próprio poeta, como podemos ler no prefácio de Poemas, em que diversos nomes são aproximados nos mesmos moldes do emblema "A Poesia é só uma" dos Cadernos de Poesia:

É contra a ausência do homem no homem que a palavra do poeta se insurge, é contra esta amputação no corpo vivo da vida que o poeta se rebela. [...] De Homero a S. Juan de la Cruz, de Virgílio a Alexandre Blok, de Li Po a William Blake, de Bashô a Cavafy, a ambição maior do fazer poético foi sempre a mesma: Ecce Homo, parece dizer cada poema. Eis o homem, eis o seu efêmero rosto feito de milhares e milhares de rostos [...] (ANDRADE, 1966, p. 10).

À procura de uma simplicidade assente em valores perenes afirmados por manifestações líricas de diversas épocas, evocados principalmente na contemplação do mundo elemental, no arraigamento à terra, na memória e raízes da infância, na fruição dos sentidos, na expressão de paixões humanas etc., a produção de Eugénio de Andrade resulta numa "poesia ao mesmo tempo retintamente nossa e de certo modo alheia" 68 . A frase é de José Gaspar Simões, crítico que aproxima o poeta de certa inclinação do "classicismo moderno", à linha de um Paul Éluard e de um Federico García Lorca.

\footnotetext{
${ }^{67}$ Transcrevemos, como exemplo, trecho bastante pertinente da apresentação crítica de Paula Morão sobre a obra eugeniana, em que a autora trata da "relaboração que Eugénio de Andrade opera das várias faces da tradição literária": "No enunciado de títulos que fizemos acima notará o leitor a presença dos nomes de alguns gêneros literários: canção, madrigal, litania, soneto, elegia, epitáfio; outros ainda se encontram na Obra Completa, como estribilho, haiku, glosa, alba, lamento, fábula, envio. Não quer isto dizer, como é óbvio, que se sigam as regras de uma retórica tradicional na composição poética. Mas o seu peso não poderia deixar de perpassar num autor que desde cedo se revelou um antologiador e tradutor atento e eclético, cuja memória da Literatura percorre os caminhos que vão de Safo a Lorca, de Camões a Ritsos ou Cavafy e aos autores portugueses que de Coimbra e do Porto se ocuparam." Poemas de Eugénio de Andrade. Col. Textos Literários. Lisboa: Seara Nova Editorial Comunicação, 1981, p. 34.

${ }^{68}$ Perspectiva histórica da poesia portuguesa (século XX). Porto: Brasília Editora, 1976, p. 403.
} 
Dessa maneira, sua obra vislumbra, de modo circunstancial, algo do "universal", pois encaminha o homem ao reconhecimento de si mesmo, "ao empenho total do ser para a sua revelação" (ANDRADE, 1966, p. 9).

Seu programa poético constitui-se de uma busca ontológica que se dá sobretudo no encontro do verdadeiro rosto humano, desfigurado, como ele diz, por uma cultura "mais interessada em ocultar ao homem o seu rosto do que trazê-lo à luz do dia" (ANDRADE, 1966, p. 9). Embora utilize vocábulos da tradição mística, como "fogo de conhecimento" e "revelação", sua poesia traça um caminho oposto ao da ascese metafísica, procurando o humanismo na materialidade do mundo e das paixões, recolhida de diversas fontes e transmutada para uma arte poética bastante original.

Porém, é preciso ressalvar que o diálogo de proximidade que a poesia de Eugénio de Andrade empreende com a tradição lírica, seja ela a mais remota, se realiza antes no chão de tensões e valores da modernidade. O poeta empreende a releitura e reinterpretação das fontes tradicionais, mas a partir de opções poéticas de matrizes modernas, a fim de efetuar sínteses inovadoras. Luís Miguel Nava, por exemplo, em resposta às repetidas associações que têm sido feitas pela crítica entre a poesia de Eugénio de Andrade e certa tradição poética da natureza - alinhada às cantigas de amigo - numa família ampla que passa por Camões e chega a Teixeira de Pascoaes, explica, em contribuição fundamental ao estudioso da obra eugeniana, a necessidade de situar essa poesia, antes de tudo, junto à moderna "explosão heteronímica" de Fernando Pessoa, a fim de se compreender as inovações de Eugénio de Andrade, geradas a partir da aliança que o poeta instala entre o mundo arcaico e a vivência do contemporâneo:

Depois dessa coisa incrível que entre nós deu pelo nome de Pessoa e de que tão a custo a nossa poesia ia tentando refazer-se, era anacrônica qualquer que fosse a escrita em cujo interior se não esboçasse uma reflexão sobre ela própria ${ }^{69}$.

Segundo Nava, Eugénio de Andrade atingiu o grau máximo de maturidade dentro da produção pós-pessoana, pois, ao contrário dos poetas de Presença e do Neorrealismo, percebeu que qualquer referência à natureza, depois do "abalo heteronímico", teria que incluir, por dentro, um questionamento dessa própria referência. Assim, Eugénio não toma a natureza por objeto, mas elabora, a partir dela,

${ }^{69}$ Luís Miguel Nava e Ángel Crespo. Apresentação de Eugénio de Andrade, o amigo mais íntimo do sol - Fotobiografia. Porto: Campo das Letras, 1998, p. 11. 
sua arte poética. O poema "Os frutos", em Ostinato rigore, expressa muito bem essa característica de sua poesia:

\section{Os frutos}

Assim eu queria o poema:

fremente de luz, áspero de terra,

rumoroso de águas e de vento.

(ANDRADE, 1966, p. 219)

Esse breve poema, como muitos outros da coletânea, oferece, a nosso ver, uma súmula da arte poética eugeniana por meio do encontro e da intersecção dos três termos mencionados no prefácio "Poética": "homem, terra e palavra"70. As unidades da palavra poética, desmembrada em "luz" (imagem) e "rumor" (som), revelam íntima ligação com os quatro elementos primordiais da natureza: "luz" (fogo), "terra", "água" e "vento" (ar). ${ }^{71} \mathrm{O}$ poema constitui-se da integração de todas as unidades originais e participa, dessa maneira, das "essências" de todas as coisas. O espasmo poético, "fremente de luz" e "rumoroso de águas e de vento", procura aquele gesto que é o começo absoluto de tudo, movimento de toda criação e de todo encontro. O fazer poético, portanto, decorre do retorno ao "ser" primordial, em que as essências dos

\footnotetext{
${ }^{70} \mathrm{Em}$ "Poética" Eugénio de Andrade afirma "fidelidade ao homem e à sua lúcida esperança de sê-lo inteiramente, fidelidade à terra onde mergulha as raízes mais fundas, fidelidade à palavra que no homem é capaz da verdade última do sangue, que é também verdade da alma" (ANDRADE, 1966, p. 11).

${ }^{71}$ No Brasil, a tese de doutoramento da professora Maria Lígia Martha Aiello A poesia de Eugénio de Andrade em tempo de metamorfose (Bauru: Faculdade do Sagrado Coração, 1985), oferece importantes subsídios à nossa pesquisa, por ter sido o primeiro estudo global desta "primeira fase" da poesia eugeniana, em que se inclui Poemas (1945 - 1965). Aiello analisou detidamente o caráter "elemental" dessa poesia, que, a partir dos quatro elementos míticos tradicionais - água, fogo, terra e ar -, empreende processos metamórficos a fim de criar novas realidades e aberturas para a palavra poética, remontando ao pensamento pré-científico do mundo antigo: "Cada composição relembra as metamorfoses de Homero, Hesíodo, Apuleio e todos os filósofos e poetas metafísicos pré-socráticos, que discutiam sobre a primordialidade da água, do ar, do fogo, da terra ou de um quinto elemento inefável, que seria infinitamente divisível ou não" (AIELLO, 1985, p. 16). A autora identifica certas mudanças no percurso poético de Poemas (1945-1965) e divide os livros da coletânea em fases, delimitadas conforme se acrescentavam novas estruturas e novos referentes no corpus poemático. $\mathrm{O}$ recorte que sugerimos também pretende contribuir para a investigação de um possível percurso poético nessas primeiras duas décadas da carreira do poeta; porém, nosso método de análise não consiste numa leitura sequencial, em que se propõe um levantamento das mudanças significativas de livro a livro - embora nossa proposta seja também apresentar um panorama das principais coordenadas poéticas em Poemas. Nosso foco principal pretende incidir, antes, em núcleos interpretativos, fundamentados na análise das imagens recorrentes e de procedimentos poéticos que percorrem a extensão dos livros da coletânea de maneira mais cíclica do que propriamente progressiva, ainda que tenhamos em vista apontar para a constituição de uma arte poética mais abrangente, desta que consideramos a primeira fase de sua obra.
} 
elementos, da palavra e do homem se interagem, pois o poema também apela aos sentidos e instintos humanos mais primitivos: "frutos" evocam o paladar, "fremente de luz" a visão, "áspero" o tato e "rumoroso" a audição. Ao despertar os sentidos geralmente adormecidos pela excessiva racionalização da vida moderna, o poema planeja resgatar ao homem a lembrança do primeiro contato com o mundo, reinstaurando o encanto perdido. Assim, o poema vibra aquele que parece ser o movimento inicial de tudo, "fremente de luz" e "rumoroso de água".

Contudo, o primeiro verso do poema revela também alguma hesitação no tom hipotético dado pelo verbo no pretérito imperfeito, "queria". O sujeito poético expõe seu esforço já sob a consciência, talvez, da fugacidade de tal reconciliação entre homem, linguagem e natureza primordial. O processo poético mimetiza o ciclo natural do "fruto": ser compacto, mas em constante transformação e abertura; síntese de todo princípio, mas que já reserva também o fim.

Desse modo, o poema apresenta, de maneira condensada, a tensão dialética que percorre e determina os núcleos identificados em cada um dos sete livros da coletânea, os quais pretendemos acompanhar a partir do próximo capítulo. 


\title{
3."DOS POEMAS (1945-1965) À IDEIA DE UMA ARTE POÉTICA"
}

\subsection{A palavra, a terra e o homem no prefácio "Poética"72}

\author{
E longamente fiquei até ouvir \\ o meu sangue jorrar na voz das fontes. \\ (Eugénio de Andrade, 1966, p. 47) \\ [...] Esse ser sedento de ser, que é o poeta, \\ tem a nostalgia da unidade, e o que procura é uma reconciliação. \\ (Eugénio de Andrade, 1966, p. 10)
}

Ao submeter as composições de Poemas (1945-1965) a minuciosa revisão, reedição e cortes, definindo o que seria uma primeira fase de sua poesia, Eugénio de Andrade escreveu, na ocasião da publicação da coletânea em 1966, o prefácio "Poética" leitor para uma dada condição de recepção dos poemas.

Nesse texto, Eugénio de Andrade registra uma espécie de concepção de sua poesia fundamentada na fidelidade a três princípios básicos: "homem", "terra" e "palavra" (1966, p.11), síntese que demonstra continuidades com as vontades modernizadoras manifestadas a partir da década de 1940, ao mesmo tempo que evidencia a ligação com elemento bastante tradicional da poesia portuguesa: o apego à terra.

Desse modo, a palavra do poeta pretende ser a palavra do homem, e, para isso, perfaz-se por meio de processos "modernizadores", que intentam decompor, na própria linguagem, a realidade preconcebida para ir ao encontro da "verdadeira vida" e com "esse animal triste que nos habita há milhares de anos, cujas possibilidades estamos tão longe de conhecer", conforme explica o poeta nesse seu texto de entrada (ANDRADE, 1966, p. 10). Assim, paradoxalmente, os recursos de modernização da palavra têm como fim resgatar tudo aquilo que é mais antigo no homem: os instintos "animais", os sentidos, a percepção e a memória ancestral do encanto primordial do homem com o

\footnotetext{
${ }^{72}$ O prefácio "Poética" encontra-se reproduzido na íntegra no anexo desta dissertação.

${ }^{73}$ Texto incluído também em Rosto precário, publicado na década de 1970, que reúne outras poéticas, como o texto "O sacrifício de Ifigênia" e o "Nascimento da música", e entrevistas com o poeta. O livro foi incluído em sua obra completa Eugénio de Andrade, poesia e prosa (1940-1979). Vila da Maia: Imprensa Nacional, 1980.
} 
mundo. Por meio da relação que se pretende simbiótica entre o "novo" e o "velho", Eugénio de Andrade reivindica a "universalidade" de sua poesia, defendida nesse texto "Poética". Assim, a terra, com suas tradições e paisagens, nos religa a uma memória da unidade há muito tempo perdida do "homem no homem". ${ }^{74}$ Ao longo do texto, o poeta enumera algumas das motivações, dos anseios e das características fundamentais de sua poesia, cujo projeto principal é o de reconciliação:

Palavra de aflição mesmo quando luminosa, de desejo apesar de serena, rumorosa até quando nos diz o seu silêncio, pois esse ser sedento de ser, que é o poeta, tem a nostalgia da unidade, e o que procura é uma reconciliação, uma suprema harmonia entre luz e sombra, presença e ausência, plenitude e carência.

(ANDRADE, 1966, p. 10)

O esforço afirmativo dessa poesia contra a ausência e a falta de unidade não pretende ocultar seus percalços: "sombra, aflição, silêncio, ausência e carência" também pertencem ao universo poético de Eugénio de Andrade e igualmente motivam a procura pelo poético. Assim, ao lado do efeito de plenitude e encantamento que a linguagem poética instaura, pressentimos a ameaça do vazio e da esterilidade.

Por conseguinte, se o poeta aponta para o que é mais antigo e universal no homem, ele também localiza seu tempo histórico e particular. Sua poesia expressa antes de tudo a dor e os anseios do "homem moderno". Embora a falta de unidade e de sentido não pertença exclusivamente à visão de mundo moderna, é nesse período histórico, entre os fins do século XVIII e XX, que a sensação de vazio e desencanto se intensifica. Entre as causas, o fracasso diante do transcendente, o quadro de instabilidade e crise institucional cada vez maior no transcorrer do século XX, em que se repensavam o estatuto da arte, da representação, do sujeito, dos valores tidos até então como imutáveis, dos modos e padrões de vida etc. Assim, as grandes transformações sociais e espirituais acarretaram uma "nova visão de mundo", ainda que

\footnotetext{
${ }^{74}$ Seria interessante ressaltar a circularidade entre os três elementos que Eugénio destaca como coordenadas de sua poética. Conforme reconhece Paula Morão em Poemas de Eugénio de Andrade: o homem, a terra, a palavra, tais premissas não representam "categorias estanques", mas "canais em permanente abertura". Assim, se acima optamos por partir de uma ênfase do elemento "palavra", a autora propõe uma análise que se inicia em "terra", mas cujos caminhos também se apresentam como circulares: "A lógica desta interpenetração é a que vem de a 'terra' ser a origem do 'homem', que a ela regressará inexoravelmente, e de a vida (quando ele se assume como poeta) se cifrar na explicitação desse ciclo pela "palavra"” (MORÃO, 1981, p. 16).
} 
velhas perspectivas não tenham sido descartadas. Nesse contexto, a "ausência do homem no homem" que Eugénio de Andrade denuncia em "Poética" é um fenômeno típico da sociedade moderna contra o qual sua poesia se insurge.

Portanto, o "mergulho" que essa poesia promove se caracteriza pela simultaneidade entre o "novo" e o "velho"; entre o "particular" e o "universal":

[...] Nesse mergulho do homem nas suas águas mais silenciadas, o que vem à tona é tanto uma singularidade como uma pluralidade. Mas, curiosamente, o espírito humano atenta mais facilmente nas diferenças que nas semelhanças, esquecendo-se, e é Goethe quem o lembra, que o particular e o universal coincidem, e assim a palavra do poeta, tão fiel ao homem, acaba por ser a palavra de escândalo no seio do próprio homem. Na verdade, ele nega onde outros afirmam, desoculta o que outros escondem, ousa amar o que outros nem sequer são capazes de imaginar.

(ANDRADE, 1966, p. 9)

O trecho acima afirma a "intersecção do espaço poético e ideológico das palavras" "75, que muito preocupou essa geração de escritores. Também apresenta continuidades com o emblema "A Poesia é só uma" dos Cadernos de Poesia, os quais, como vimos, a despeito dos rótulos que na época eram atribuídos à literatura, defendiam a especificidade e o caráter abrangente do objeto literário, tão "singular" quanto "universal".

A poesia, nesse sentido, pretende captar a "essência" ao mesmo tempo mutável e imutável do "ser". O "empenho total do ser" que caracteriza o "acto poético", como define Eugénio de Andrade no texto, aponta para a natureza abrangente e inexaurível tanto do homem como da poesia e do mundo fenomênico. A vida se pressente frágil e fugaz, e pelo mesmo motivo é também celebrada. Eugénio de Andrade afirma uma poética capaz de reconciliar uma série de vivências antagônicas e contraditórias em relação ao tempo, ao sujeito, ao amor, à poesia. Por conseguinte, a palavra é "total" quando atinge o grau máximo de abertura e abrangência.

A ênfase na palavra e no homem em "Poética" demonstra, pois, a adesão de Eugénio de Andrade ao projeto modernizador de seu tempo, que pretendia repensar a

\footnotetext{
${ }^{75}$ Expressão de Fernando Guimarães. A poesia contemporânea portuguesa. Vila Nova de Famalicão: Quasi Edições, 2002, p. 17.
} 
linguagem poética a fim de mantê-la em sua capacidade interventora. O recurso à expansão imagética, fruto do "imaginar" criador, era um dos principais meios em vigor durante a década de 1940 para se atingir a "combustão verbal" capaz de "estabelecer a integração do homem no mundo", por outra via que não a de uma ideologia, conforme teorizou, alguns anos mais tarde, António Ramos Rosa, poeta que estreou em fins de 1950 e que mais uma vez aqui reproduzimos:

Pela imaginação poética - e só por ela - todas as energias do universo ascendem à palavra, como afirma Gabriel Bounure. [...] O homem no homem, o homem no universo, a vida de novo na sua ardência primeira, o esplendor da criação, a aliança entre sonho e realidade, a identificação dos contrários, a comunhão fraterna - tudo se consubstancia neste sonho que não é sonho, pois que ele é a realidade primeira e a única realidade a conquistar.

(ROSA, 1962, p. 12)

Como vimos, imaginação e desejo eram vias de acesso propostas também pela arte surrealista à "energia criadora", capaz de conectar o poeta ao dom interior da linguagem a fim de que se produzisse uma "combustão verbal" que libertasse o homem de sua existência confinada e a ele revelasse seu "verdadeiro rosto" - conforme escreve Eugénio de Andrade - já desfigurado pela ação da cultura. A palavra, posta em movimento no "acto poético" - definido pelo poeta como "fogo de conhecimento que é também fogo de amor" (ANDRADE, 1966, p. 9) -, é gerada, portanto, pela combinação imaginação-desejo, ambos capacidades produtoras de imagens que respondem à tendência de "transformação radical ou metamorfose" inerente ao "homem autêntico", tanto quanto ao "poeta", segundo Ramos Rosa (ROSA,1962, p. 25).

Em alinhamento com os experimentalismos formais de outras manifestações de vanguarda do começo do século $\mathrm{XX}$, a arte surrealista mantinha o princípio de que o exercício da imagem providenciaria o exercício concreto da liberdade humana, pressuposto recuperado e difundido pelo movimento surrealista português e bastante praticado pelos poetas portugueses das décadas de 1940 e 1950, em abertura para a experimentação radical que viria acontecer na Poesia de 61 em Portugal.

Por outro lado, a inclusão do elemento terra como princípio básico de sua poesia traz, de certa forma, uma reorganização dessa visão, no cuidado de rejeitar qualquer tipo 
de tendência abstrata da imaginação e da produção de imagens, conforme expõe o próprio poeta, em trecho de entrevista incluída em Rosto precário:

Não é do português o gosto pela especulação abstrata, ou da religiosidade entranhada, ou da imaginação fecunda. O que é nosso sem fingimento move-se numa terra de sentidos despertos. Tudo o que em nós é voo, e sobe às vezes muito alto, tem no corpo o seu nascimento primeiro, e não se perde nunca o sabor das fontes. Aquilino usou, para nos caracterizar, de uma expressão brutal, mas certeira, o melhor do país cheira a estábulo. A frase tem uma abertura enorme, mas sempre no sentido da terra, dos instintos, do calor animal. É a partir do homem de carne e de sentido que ascendemos à brancura rarefeita de uma neve que sobre nós cai, nupcial ${ }^{76}$.

Para esse poeta que definiu nessa mesma entrevista sua poesia como uma mistura de "brutalidade e ternura", a pureza da "brancura" e da "neve nupcial", tão procurada em sua poesia, irradia no poema quando o estado de inocência é reinstaurado, quando o sentido usual da palavra se esvazia para que ela volte a colar-se à vivência da terra, do corpo, do campo, da natureza, do mundo animal, das substâncias elementares. E em contínua transcendência, possa experimentar novas disponibilidades de sentido, resgatando significações já esquecidas em nossa sociedade industrial e mecanizada, mas que ainda se encontram resguardadas numa espécie de memória primordial. Assim, Eugénio de Andrade afirma em seguida: "Eu creio que a plasticidade da minha poesia começa na palavra, sempre sensualmente muito apegada à matéria, e só depois se torna extensiva à imagem” (MEDINA, 1983, p. 70).

A palavra, portanto, igualmente irá valer-se da terra como material poético. Conforme aponta Maria Lígia Martha Aiello, o processo de metamorfose, muito frequente na poesia de Eugénio de Andrade, parte sempre dos quatro elementos fundamentais: terra, água, fogo e ar, remetendo ao pensamento pré-socrático e ao conceito grego da Physis: "O saber do ente na sua totalidade. A palavra physis, quando ligada ao mundo vegetal, significa, na voz ativa, 'produzir' e, na voz média, significa 'crescer'. O reino vegetal seria assim a origem de todas as coisas, que a partir daí se desenvolvem constantemente". ${ }^{77}$ Dentre os elementos primordiais, a terra, como indica Aiello, é a mais fecunda como "geratriz das metamorfoses" (AIELLO, 1985, p. 19).

\footnotetext{
76 Eugénio de Andrade. Poesia e prosa (1940- 1979). Vila da Maia: Imprensa Nacional, 1980, p. 304.

77 Maria Lígia Martha Aiello. A poesia de Eugénio de Andrade em tempo de metamorfose. Bauru: Faculdade do Sagrado Coração. 1985, p. 17. E também: “Physis' na língua grega designa o que é
} 
Portanto, ao recompor a ligação perdida entre palavra, homem e terra (ou "mundo" e "coisas"), o poeta se rebela contra a "amputação no corpo vivo da vida" (ANDRADE, 1966, p. 10), empreendida pela cultura. Seu canto clama por um retorno à plenitude adâmica, em que a linguagem estabelecia o encontro primordial entre o homem e as coisas, ainda que seu canto deixe entrever certa ausência. Afinal, conforme ressalvou Eduardo Lourenço, a palavra poética pode nos revelar, mais do que o paraíso, o abismo que nos separa dele e da Unidade. ${ }^{78}$

Dessa maneira, os três elementos distinguidos em "Poética" guardam, em sua poesia, uma relação de identidade e continuidade orgânica: um está em constante procura do outro, configurando um sistema poético bastante singular. Tal sistema organiza o mundo na própria linguagem e estabelece um diálogo fecundo de dupla mão: de um lado com a modernidade da década de 1940, recuperadora de alguns dos projetos das vanguardas e do modernismo do início do século, e de outro com as mais diversas tradições antigas - não só da lírica portuguesa, mas também da poesia meridional.

Com frequência, o poeta inclui em seus poemas paisagens da poesia clássica, recupera valores humanistas e a memória contida na própria linguagem, em que se deslocam as acepções usuais de nosso mundo contemporâneo. Sua poesia ainda resgata formas, símbolos e temas não só da poesia greco-romana, mas também da poesia oriental, da lírica trovadoresca, da Geração Espanhola de 27, da poesia de Camões, de Camilo Pessanha, de Fernando Pessoa, de certa tradição dos românticos alemães, de autores ingleses, etc. Influências ora apontadas pela crítica, ora aclamadas pelo próprio poeta:

A cal e os cardos dos meus versos tanto podem ser os do Alentejo como os de Epidauro; as oliveiras de Castelo Branco confundem-se na minha memória com as de Corfu ou as de Maiorca. Num só poema, às vezes num só verso, podem fundir-se várias imagens, algumas próximas, outras longínquas. No leito da poesia correm muitas vezes as águas da contradição ${ }^{79}$.

primário, fundamental e persistente. Os próprios deuses gregos não são entidades sobrenaturais, mas são compreendidos como parte integrante da natureza. Assim physis significa a totalidade de tudo o que é, podendo ser apreendida em todos os acontecimentos: a aurora, o crescimento das plantas, o nascimento de animais, os homens, os próprios deuses", idem, p. 18.

78 "A poesia de Eugénio de Andrade". 21 ensaios sobre Eugénio de Andrade. Porto: Inova, 1971, Col. Civilização Portuguesa, p. 40.

79 "Rosto precário". Eugénio de Andrade. Poesia e prosa (1940-1979). Vila da Maia: Imprensa Nacional, 1980, p. 326. 
Logo, ao dedicar atenção a esses três valores fundamentais à "poesia de sempre", Eugénio de Andrade aponta para o que é simultaneamente moderno e eterno em toda a poesia, reafirmando o lema "A poesia é só uma" dos Cadernos de Poesia. Sua poesia contém, assim, um grande conjunto de temas e elementos tradicionais, porém dispostos de maneira a se "modernizarem" no cerne do poema, compelidos pela própria linguagem à constante transmutação.

Palavra, terra e homem decompõem, de maneira aparentemente simples, o sistema complexo de sua poesia, em que uma multiplicidade de vozes e de elementos se encontram. Na conjugação dos três fundamentos de sua poesia, podemos distinguir ainda uma série de unidades menores que frequentemente são destacadas ao longo dos poemas da coletânea. Assim, temos que a palavra estruturalmente se desdobra em "imagem" (principalmente referida em termos de "luminosidade") e "som" ou "música" ("rumor”), e sua gênese será motivada pelo "amor", pelo "desejo" e pela "memória", nas condições ideais de "espera" e "entrega". Homem é aludido pela presença do "corpo", dos "sentidos", dos "sentimentos" ou "afetos", do "imaginar" (aqui como capacidade produtora de imagens), do "desejo", elementos esses que "dormem e sonham" no substrato da própria linguagem, em que se evoca também a "memória" e a "experiência", as quais logo remetem à terra, signo de toda origem, traduzida na materialidade da "natureza" e dos "elementos primordiais". Os elementos, por sua vez, em uma relação de circularidade, são o próprio corpo e a substância da palavra, aludida, por exemplo, pela metáfora dos "frutos", conforme veremos na análise do primeiro livro da coletânea, ou pela imagem da "ave", que aponta para a transitoriedade da linguagem poética.

Por conseguinte, a contínua metamorfose dos quatro elementos primordiais, como apontou Aiello, gera múltiplas e infinitas imagens que restabelecem a contiguidade entre todos os elementos evocados. O estado analógico que essa poesia mantém permite a "posse do mundo e de si mesmo" 80 e alarga o espaço em que se faz a poesia através do constante gerar de estruturas novas, causando um efeito de reversibilidade, em que tempos distintos convivem, e intensificando o efeito do "acto poético" - ou, como define Benedetto Croce, o processo de "revocação" da poesia:

\footnotetext{
${ }^{80}$ Expressão de Eduardo Lourenço. "A poesia de Eugénio de Andrade”. 21 ensaios sobre Eugénio de Andrade. Porto: Inova, 1971, p. 34.
} 
[...] Se a expressão poética renasce de tempos em tempos no "eu" que se modifica, ela igualmente renasce nos outros homens que, devido à humanidade comum, identificam-se com esse "eu" e são seus contemporâneos e seus pósteros através dos séculos. Isto é o eterno renascer; é a revocação da poesia. A revocação só pode efetuar-se como um novo percorrer do processo criativo da expressão. [...] Revocação que deve ser relacionada ao gênio-gosto, ou ao gênio que criou a expressão e que a recria perpetuamente. Esse gênio que a criou não é o gênio deste ou daquele indivíduo, mas [...] o gênio da humanidade. [...] Não é nem mais nem menos a capacidade de acompanhar a poesia, de viver com ela, de refazer o seu processo criativo. E, como tal, é sempre adquirida $\left[\ldots . .{ }^{81}\right.$

O conceito de "revocação" é amplo o suficiente para abarcar todo encontro que a poesia permite efetuar: a convivência entre os tempos, entre os homens, entre o indivíduo e seu tempo, entre memória e linguagem, entre o particular e o universal, entre tudo aquilo que envolve a escrita, incluindo a comoção e o lirismo pessoal do poeta, suas experiências e memória, seus princípios, teoréticas e conhecimento transfigurados em expressão poética. E também o ato de leitura, que não se constitui, segundo Croce, de uma mera recriação, embora participação criativa seja um pressuposto dela, mas de um verdadeiro estado de entrega e identificação com o "eu" que é simultaneamente do poeta e de todos os homens, um verdadeiro reconhecimento de si mesmo, uma chegada ao substrato humano comum - ainda que exija também uma adequação a certos meios históricos e sociais particulares para que a poesia possa de fato comunicar. $\mathrm{O}$ ato poético se torna, nesse sentido, instante que se alarga para reaver e conciliar todas as capacidades humanas unidas sem intervalo. O poema pode, assim, ocasionar a percepção da totalidade abrangente da existência, desmascarando, por outro lado, a incompletude do homem e da vida moderna.

Os três termos aparentemente simples apresentados por Eugénio de Andrade em "Poética" sugerem a rede complexa de problemas que a tradição da poética tem enfrentado, desde seus primórdios, acerca da natureza e função da poesia, do material e dos efeitos do poético, de suas relações com a tradição e com o "novo", principalmente motivado pelas transformações históricas e sociais. Tais termos e relações apresentados no prefácio serão objetos de indagações ao longo de cada um dos sete livros.

\footnotetext{
${ }^{81}$ A poesia - introdução à crítica e história da poesia e da literatura. Benedetto Croce. Trad. Flávio Loureiro Chaves. Porto Alegre: UFRGS, 1967, pp. 79 e 86.
} 


\subsection{O ciclo orgânico do "fruto"}

Canto porque o amor apetece.

(Eugénio de Andrade, 1966, p. 22)

A poesia seria cúmplice, desde o começo, desse sentimento que se chama amor.

Eu acho que é uma coisa perfeitamente lógica, natural, porque a poesia, se vocês olharem bem, ela é o amor entre os sons e os sentimentos.

(Paulo Leminski, 1999, p. 290)

Em Eugénio de Andrade, o amor coincide com a poesia ${ }^{82}$, na medida em que inspira e gera seu cantar. Dentro dos moldes da tradição que transformou "o amor em metáfora do canto" e "o canto uma imagem do amor" (KRISTEVA, 1988, p. 320) ${ }^{83}$ o poema de abertura de As mãos e os frutos (1945-1948), primeiro livro da coletânea, marca essa aproximação por meio de duas metáforas ou "signos carregados" para tomar emprestado a expressão de Nava:

Só as tuas mãos trazem os frutos.

Só elas despem a mágoa

destes olhos, choupos meus,

carregados de sombra e rasos de água.

Só elas são

estrelas penduradas nos meus dedos.

- Ó mãos da minha alma,

flores abertas aos meus segredos!

(ANDRADE, 1966, p. 17)

As "mãos" aludem ao estado de entrega do amante, e entrelaçadas às mãos do eu lírico, como "estrelas penduradas nos meus dedos", trazem os "frutos" de que se alimentará esta poesia, metáfora circunspecta que, como também apontou Vergílio Ferreira, poderia muito bem servir a toda arte poética eugeniana: "Fechado, uno, compacto, não há senão que saboreá-lo, admirá-lo, tocá-lo a dedos puros para o não conspurcar [...]. Tal poesia é toda ela uma sequência de metáforas, quando não é só uma

\footnotetext{
82 "Em Eugénio de Andrade, há uma rigorosa coincidência entre o amor e a poesia", expressão de Gastão Cruz, em "Função e justificação da metáfora na poesia de Eugénio de Andrade". 21 ensaios sobre Eugénio de Andrade. Coleção Civilização Portuguesa. Porto: Editorial Inova, 1971, p. 129.

${ }^{83}$ Julia Kristeva trata especificamente da tradição trovadoresca, mas também remonta brevemente à lírica grega: "Antes de ser uma arte de amar, ou antes porque o é, e ao mesmo tempo que o é, a cortesia é uma enunciação. [...] Primeiramente, como a lírica grega, esse discurso de amor é um canto", em "Os trovadores: do 'grande canto cortês' à narrativa alegórica". Histórias de amor. São Paulo: Paz e Terra, 1988, p. 314.
} 
metáfora". ${ }^{84}$ Desde o título ao poema de abertura do livro, "mãos" e "frutos" permanecem, assim, signos determinantes no decorrer de todo o volume. A centralidade das "mãos" reside, talvez, na mediação que elas realizam entre o poeta e o amante, entre o poeta e o mundo circundante, e entre o poeta e o ato da escrita. Quando unidas às mãos do amante, são referidas a uma espécie de luminosidade - "estrelas penduradas" nos dedos - que, como em muitos outros momentos da coletânea, poderia remeter ao poder genesíaco da escrita. As mãos surgem, portanto, como instrumentos tanto do amor quanto da escrita e são evocadas nesse poema de abertura como se cumprissem o canto anunciado, desperto pelo encontro amoroso.

Em conformidade com a grande tradição da poesia ocidental, o amor é celebrado em As mãos e os frutos em sua capacidade de "fecundar o deserto da existência" 85 . O amor despe a "mágoa dos olhos choupos" do sujeito, traz "os frutos" e inspira o canto, aberto à expressão da "alma" e de seus "segredos". Desde a tradição trovadoresca, o amor foi elevado à condição de primeiro grande tema da inspiração lírica e, a partir de então, o processo amoroso, juntamente com a descrição da elaboração da escrita poética, passou a ser frequentemente destrinçado no poema, aguçando-se a consciência da atividade artística e a descoberta e espiritualização do amor como fulcro da inspiração lírica, conforme explica Segismundo Spina em A lírica trovadoresca ${ }^{86}$. A tradição trovadoresca occitânica ou provençal, que se desenvolveu na região sul e meridional da França, sendo depois praticada também na Península Ibérica (embora com marcadas diferenças) ${ }^{87}$, a partir do século XII, pregava a vivência do joie dámour,

\footnotetext{
${ }^{84}$ Vergílio Ferreira em "Breve périplo vocabular da poesia de Eugénio de Andrade". 21 ensaios sobre Eugénio de Andrade. Porto: Editorial Inova, 1971, p. 438.

${ }^{85}$ Expressão de Alexandre Pinheiro Torres em "O conflito entre o instinto e a sociedade, em As mãos e os frutos de Eugénio de Andrade”. 21 ensaios sobre Eugénio de Andrade. Porto: Editorial Inova, 1971, p. 5. ${ }_{86}^{8}$ São Paulo: Edusp, 1996, p. 24.

${ }^{87}$ Maria Leonor Buescu explica algumas das inovações da poesia trovadoresca galego-portuguesa em relação à lírica occitânica: "Contudo, enraizando-se em Portugal, a poesia provençal modifica-se e nacionaliza-se: torna-se mais 'portuguesa' quer pela forma menos rígida, quer pelo conteúdo, menos convencional, em que o amor cortês se aproxima da paixão sentimental tão tipicamente lusitana. Mais do que decalcada do lirismo provençal, a cantiga de amor portuguesa é uma recriação original de que o próprio rei-trovador D. Dinis (1261-1325) se apercebe: 'Os provençais costumam trovar com perfeição e, dizem eles, com amor. Mas os que trovam no tempo da flor e não em outro não têm a paixão que eu tenho e me há-de matar... "”. Iniciação à literatura portuguesa. Lisboa: Plátano Editora, 1973, p.15. A “coita d'amor", ou sofrimento amoroso, seria uma particularidade da sensibilidade galego-portuguesa e como núcleo temático constituiu uma novidade para a poesia trovadoresca produzida em Portugal. Cf. também a descrição de João Gaspar Simões, em História da poesia portuguesa: “[...] Se é verdade que os poetas trovadorescos galego-portugueses se adaptaram a essa mestria no trovar, o certo é que não podem ter encontrado na cantiga de amor o modelo ideal para uma identificação profunda com a sensibilidade que dentro deles fremia insatisfeita. Os artifícios e as subtilezas da dialéctica amorosa implícita nesse gênero poético repeliam o que de mais instintivo e natural devia manifestar-se no temperamento amoroso da
} 
ou a "alegria da paixão amorosa", em todas as suas dimensões, com vistas a atingir o amour comblé, o "amor integral", aquele que envolve não só os sentidos, mas também a inteligência ou o espírito dos amantes, como revela o trecho do poema de Bernard de Ventadorn:

\author{
Chantars no pot gaire valer, \\ si d'ins dal cor no mou lo chans; \\ ni chans no pot dal cor mover, \\ si no i es fin'amors coraus. \\ Per so es mos chantars cabaus \\ qu'en joi d'amor ai et enten \\ la boch'e.ls olhs e.l cor e.l sen.
}

(Pouco valor tem o cantar se o canto não brota de dentro do coração; mas o canto não pode surgir de dentro dalma, se nele não existe um amor leal e cordial. Por isso é meu cantar perfeito, pois no gozo do amor eu tenho e emprego a boca, os olhos, o coração e a inteligência.) ${ }^{88}$

\title{
O “cantar perfeito" expressava o "amor integral”, tão nobre e espiritual quanto o
} fruir dos sentidos, de modo que o poeta só conseguiria manifestar verdadeiramente a “alma" se partisse do coração em direção à inteligência, aludida no poema pelas qualidades da "lealdade" e da "cordialidade". "Olhos", "boca", "coração" e "inteligência" formavam as etapas do processo amoroso, cuja trajetória hierárquica conduzia o amante ao reconhecimento da beleza e da perfeição, manifestações da divindade na terra ${ }^{89}$. Esse espírito analítico, portanto, em que se traçavam os estados

gente galego-portuguesa. [...] Bem certo que o sofrimento amoroso expresso nas cantigas de amor em que o namorado canta uma amante ideal inatingível muito naturalmente poderia encontrar acentos originais na lira dos trovadores galego-portugueses" (SIMÕES, 1985, p. 57).

${ }^{88}$ Poema transcrito e traduzido por Spina. Idem, p. 24.

${ }^{89}$ Faz-se necessário aqui uma nota sobre a complexidade da concepção amorosa na lírica trovadoresca, de cujas fontes emanou todo o lirismo europeu dos séculos posteriores (SPINA, 1996, p. 17). Aliás, seria interessante ressaltar o caráter sempre inesgotável do tema do amor, cujos primórdios, como bem apontou José Américo Motta Pessanha, ao tratar do amor em Platão, se perdem em tempos remotos: "O que dele temos, na verdade, é a série descontínua de falas ou variações na qual entramos sempre tardiamente: sequência fragmentada de múltiplos e heterogêneos discursos, esfacelada por falhas, hiatos, silêncio. Nunca um discurso inteiro e contínuo - mas retalhos dispersos, discursos díspares e descosidos", em "Platão: as várias faces do amor". Os sentidos da paixão. Org. Adauto Novaes. São Paulo: Funarte e Companhia da Letras, 1999, p. 77. Da mesma maneira, o amor, na lírica trovadoresca, é um tema depurado e múltiplo, tão "alegre" quanto "ideal", que envolve uma série de discursos e linguagens diferentes e expressa antagonismos fundamentais vividos na época entre "impulsos mundanos e transcendentes, sensuais e espirituais" (HAUSER, 1998, p. 209). Esses antagonismos, de inspiração platônica e cristã, receberam também influências da erótica ovidiana, dos cantos primaveris populares, da mítica folclórica da fertilidade, das carjas árabes, etc. Maurice de Gandillac aponta para a incorporação, por parte do "amor medieval", tanto da noção platônica do amor como Eros - filho da "Pobreza" e do "Expediente", que mediava os homens e os deuses, inspirando nos primeiros o desejo pela superação das condições de miséria e inferioridade - quanto da noção de Agape do Novo Testamento, amor como dom 
psicológicos do sujeito que ama, passou a ser manifestado na poesia portuguesa. $O$ processo amoroso era narrado em todas as suas etapas, em que os "olhos" veem e reconhecem a beleza. A "boca" fala ou canta" em expressão do enternecimento amoroso. E o "coração" 91 permite o liame do "corpo e da alma": a passagem à inteligência, que apreende o sentido maior da existência. $\mathrm{O}$ amor era, assim, visto como um exercício em que o amor espiritual e a Joie (alegria dos prazeres físicos) se justapunham, levando os amantes à entrega completa de si, ao caminho da espiritualização.

No poema de Eugénio de Andrade, o amor é motivação central da palavra, e o ponto de encontro entre o processo amoroso e o poético também é descrito desde sua origem. Porém, há uma inversão do modo concebido pela tradição neoplatônica ${ }^{92}$, pois,

inspirado, "graça que se precipita por pura condescendência sobre a criatura pecadora", em "O amor na Idade Média". O Desejo. Org. Adauto Novaes. São Paulo: Companhia das Letras, 1999, p. 197. Julia Kristeva também ressalta a ambiguidade do discurso amoroso trovadoresco: "A ambiguidade já notada em outros trovadores instala-se no vocabulário cortês, sempre erótico e ao mesmo tempo sentimental, mas vai tecer aqui o sentido profundo do estado amoroso enquanto tal. Não somente o concreto e o abstrato se superpõem [...] e as conotações eróticas infiltram a veneração frustrada da Dama [...], mas os pares de opostos fundam o texto desde o início.", em “Os trovadores: do 'grande canto cortês' à narrativa alegórica". Histórias de amor. Trad. Leda Tenório da Motta. Rio de Janeiro: Paz e Terra, 1988, p. 319.

90 Segundo José Américo Motta Pessanha, desde Platão que "amor" e "fala", ou "amor" e "discurso" ou "palavra" encontram-se intimamente ligados: "Há para Platão cumplicidade entre Logos e Eros". (PESSANHA, 1999, p. 77). Pessanha cita o exemplo do diálogo Crátilo, em que Sócrates aproxima "Eros", "herói" e "linguagem" através de uma explicação etimológica bastante "inspirada", em que se revela uma ligação subterrânea entre amor e fala: “[...] No fundo, a raiz do heroísmo é o amor, pois o herói é, ele mesmo, obra de Eros. Por dentro de 'Eros' e de 'herói' passa o significado de falar, questionar, dizer [pois o herói manifestava suas qualidades principalmente na fala, sendo ótimo orador e hábil questionador]. Por isso, Logos e Eros são inseparáveis. Por isso também é que em todos os seus tipos e níveis o amor é falante, discursante" (PESSANHA, 1999, p. 86).

${ }^{91} \mathrm{O}$ "coração", no poema de Bernard de Ventadorn, se oferece como ponto de intersecção entre corpo e espírito. Na acepção popular, conforme explica María Zambrano, o coração se apresenta como "espaço que dentro da pessoa se abre para acolher certas realidades", como "interioridade aberta", espaço de profundidade e nobreza, simultaneamente aberto ao exterior sem perder sua condição de interioridade e de intimidade. O "coração" pode também indicar, de acordo com a filósofa, aquele espaço íntimo em que se encontra a resolução de um conflito interior, de onde saem as grandes verdades e certezas, e por isso, une-se tanto ao corpo quanto à inteligência, pois seu ardor suscita o pensamento, ao mesmo tempo que se mantém intimamente agarrado às entranhas, "vivo a todo momento, oferecendo-se como pura chamada amorosa". A metáfora do coração, Lisboa: Assírio \& Alvim, 2000, p. 22.

92 Tal inversão, no entanto, não constitui novidade na poesia portuguesa, já que, desde Camões, encontramos expressões de extremo erotismo, enformadas em meio a uma "subtil dialética do amor e do desejo", conforme afirma Jorge de Sena: "Há que ter presente tudo isto para melhor se compreender como o chamado 'petrarquismo' de Camões tinha muitos antigos antepassados na literatura nacional em que se insere, exactamente como o 'platonismo camoniano' é menos uma ascensão à Suma Beleza, que uma sublimação cátara do desejo que tortura a "baixa e finita mente humana" e da donjuanesca insatisfação dos sentidos de um homem obsessivamente subjectivo, o que é, de resto, uma forma de interpretar, sócioliterariamente, a precessão plotiniana em Camões." Em “A poesia de Camões". Trinta anos de Camões (1948-1978). Vol. I. Lisboa: Edições 70, 1980, pp. 26 e 36. Porém, embora o elemento erótico não se restrinja à concepção moderna do amor, a poesia moderna promoveu, de maneira mais sistemática e programática, a inserção do corpo, de modo a embaralhar as tantas divisões e dualidades da cultura ocidental. O corpo constitui, assim, elemento fulcral da poesia eugeniana: origem e fim de todo o 
se nesse poema de abertura o ponto de partida do sentimento amoroso recai sobre as "mãos", ou seja, na fruição dos sentidos e do corpo, elas ainda permanecem como elemento fulcral de todo o processo, capazes de despir "a mágoa destes olhos choupos", "carregados de sombra e rasos de água". As "mãos" trazem a consumação amorosa e permitem ainda o primeiro estágio da escrita poética: "Mãos da minha alma, flores abertas aos meus segredos”. Há, portanto, a subversão da hierarquia neoplatônica à qual respondia a concepção amorosa tradicional, em que o entendimento, e não o corpo, cumpria a verdadeira vocação amorosa. ${ }^{93}$ Em Eugénio de Andrade, as “mãos" permitem a inserção do corpo, do tato e da fruição dos sentidos como realização máxima do amor, capaz de transformar o estado de espírito do sujeito. Os "frutos" também deslocam o sentido bíblico do pecado original, revalorizando o amor carnal e o desejo como fontes de plenitude para o homem em encontro com a "palavra" e com a "alma", conforme anunciara já Eugénio de Andrade em "Poética".

É importante aqui considerar que o próprio trovadorismo galego-português, embora assimilado do lirismo occitânico, apresentou, por sua vez, inúmeras inovações, entre elas a adesão ao tópico da "coita d'amor", ou sofrimento amoroso (conferir nota 6), tão presente na sensibilidade galego-portuguesa. Sobre esse tópico, Giuseppe Tavani fornece algumas características principais, em Trovadores e jograis: introdução à poesia medieval galego-portuguesa:

O campo sémico da "coita de amor", ainda que realizado no plano lexical por uma longa série de termos e expressões tópicas, é caracterizado por uma unidade e por uma coesão internas ainda mais sólidas do que as assinaladas para outros campos sémicos. Em suma, o motivo da "aflição do amante" gira em torno do termo coita, e engloba por um lado os instrumentos e as circunstâncias da sua manifestação, e por outro os resultados que dela derivam, segundo uma linha que parte dos olhos do poeta e da sua imprudente exposição

\footnotetext{
processo amoroso; local da máxima realização do amor e da palavra poética.

${ }_{93}$ Octavio Paz explica em A dupla chama. Amor e erotismo o sentido das etapas amorosas dentro dessa tradição influenciada pela concepção platônica: "Devemos a Platão a ideia do erotismo como um impulso vital que ascende, degrau por degrau, até a contemplação do bem supremo. Essa ideia contém outra: a da paulatina purificação da alma, que, a cada passo, distancia-se mais e mais da sexualidade, até que, no auge dessa ascensão, dela se despoja inteiramente." São Paulo: Editora Siciliano, 1994, p. 24. Na poesia de Eugénio de Andrade, o erotismo jamais desaparece do processo ou vivência amorosa. O impulso sexual e a fruição do corpo são caminhos para a experiência poética e a comunhão do sujeito com os elementos. Por outro lado, Eugénio de Andrade não nega a "alma", nem reduz o espírito humano às funções corporais, como é muito comum em nossa época, que minou o conceito de "alma" e com isso a noção de "pessoa", conforme indica ainda Paz: "A pessoa é um ser composto de uma alma e um corpo. [...] Há uma conexão íntima e casual, necessária, entre as noções de alma, pessoa, direitos humanos e amor". Idem, p. 115.
} 
à presença da dama, passa através das várias gradações do sofrimento e acaba no pranto e, mais frequentemente, na loucura e na morte por amor.

(TAVANI, 2002, p. 178)

O poema de abertura de As mãos e os frutos não trata de uma ausência ou recusa amorosa, como se fazia mais frequentemente na tradição das cantigas de amor galegoportuguesas. No entanto, a despeito da manifestação jubilante das "mãos" como veículo da realização amorosa, o poema sugere, por meio da presença dos "olhos" magoados, a existência anterior de um momento de profundo sofrimento amoroso, tal como comum no tópico da lírica trovadoresca portuguesa - sofrimento que volta a ser lamentado mais adiante, ao longo do livro. Esse poema de abertura toma, porém, uma direção diferente: a chegada das "mãos" do amado acaba por despir a "mágoa destes olhos, choupos meus".

Desse modo, se na tradição lírica medieval os "olhos" permitiam a contemplação do espírito rumo a um estado meditativo, que animava a inteligência para a apreensão total do amor, os "olhos" na poesia de Eugénio de Andrade são frequentemente aliados à "mágoa", à "tristeza" e ao ceticismo - conforme já acontecia na tradição galegoportuguesa -, expressando o estado doloroso do sujeito cindido, em face da sistemática separação entre corpo, consciência e natureza empreendida pela cultura. Os "olhos" poderiam manifestar, agora no caso mais específico da poesia eugeniana, o sofrimento, a solidão e a esterilidade suscitados pela excessiva racionalização da vida moderna, como podemos observar nos versos do poema 21 do mesmo livro, em que o amor não encontra mais a consumação esperada através de suas etapas, e a "mágoa" sobe "aos olhos" novamente:

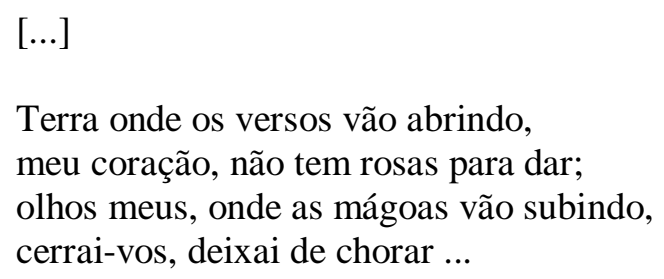

Terra onde os versos vão abrindo, meu coração, não tem rosas para dar; olhos meus, onde as mágoas vão subindo, cerrai-vos, deixai de chorar ...

(ANDRADE, 1966, p. 40)

Temos, assim, que os "olhos", em muitos momentos da obra eugeniana, expõem "toda a desgraça do olhar metafísico ocidental" $"$, em que sujeito e objeto se encontram

\footnotetext{
${ }^{94}$ Expressão de Leyla Perrone-Moisés, ao analisar a questão do olhar na obra de Fernando Pessoa.
} 
radicalmente cindidos, e o indivíduo isolado e amputado do "corpo vivo da vida" como disse o próprio poeta em seu texto de introdução (ANDRADE, 1966, p. 10) -, imerso numa existência vazia, autovigilante e solitária. Dessa maneira, na poesia eugeniana, o estado inteligível não é o fim que a poesia pretende atingir, como acontecia na lírica tradicional occitânica, mas a condição "doentia" anterior ao poema, em que o sujeito pensante sofre e anseia pelo encontro amoroso, pela possibilidade de reconciliação com o corpo, com a natureza, com a palavra e consigo mesmo.

O poema de abertura do livro, por conseguinte, ao descrever o início do ciclo amoroso e o despertar da palavra poética, também descreve o fim de um estágio anterior de dor e sofrimento do sujeito poético. Porém, ao longo do livro, esse mesmo ciclo amoroso encontra desgaste e o sujeito poético retorna à condição de "espera" daquele ritmo tanto amoroso quanto poético, como observamos no décimo primeiro poema:

Olhos postos na terra, tu virás

No ritmo da própria primavera,

E como as flores e os animais

Abrirás nas mãos de quem te espera.

(ANDRADE, 1966, p. 29)

Os "olhos" são lançados para baixo em atitude quase desesperada, "postos na terra", em posição que rejeita qualquer possibilidade de pensamento "alto" e especulativo, separado do corpo, em direção ao "mundo das ideias"95 ou em ascese metafísica. Os "olhos” procuram a materialidade da vida e dos sentidos, voltam-se para a "terra", "onde os versos vão abrindo", como indica o vigésimo primeiro poema. A palavra e o amor surgem como promessas, mais uma vez corporizadas em "mãos",

"Pensar é estar doente dos olhos". O olhar. (Org.) Adauto Novaes. São Paulo: Companhia das Letras, 1988, p. 343.

${ }^{95}$ Segundo José Américo Motta Pessanha, a partir de Platão substitui-se, na filosofia, o "eixo horizontalretroativo, típico do pensamento pré-socrático, pelo eixo ascensorial, verticalizante" (PESSANHA, 1999, p. 81), em que o pensamento adota novo roteiro: "A altura é o Oriente propriamente platônico. A operação do filósofo é então determinada como ascensão, como conversão, isto é, como movimento de se voltar para o princípio do alto, do qual ele procede, e de se determinar, de se preencher e de se conhecer graças a uma tal determinação" (Deleuze apud Pessanha, ibidem). O crítico explica que essa conversão ocorreu por diversas razões: religiosas, por influência da corrente "astral" órfico-pitagórica, que via a condição terrena do homem apenas como uma passagem purificadora rumo à "Ítaca celeste", e científicas, representadas pela vertente do pitagorismo, "que fazia da matemática a via ascensional de salvação da alma e da pólis, o caminho de retorno ao reino da claridade, da proporção, da harmonia, da justeza e da justiça" (idem, p. 82). A poesia de Eugénio de Andrade retoma o pensamento analógico e o "eixo horizontal-retroativo" do pensamento pré-socrático, ainda que também dialogue com a tradição platônica, principalmente no tratamento de temas, como pudemos observar. O pensamento pré-socrático, conforme Pessanha, é "mítico antes de ser filosófico: fabula, conta uma história, descreve uma gênese - do universo, de todos os seres - a partir de um começo, um princípio-início, uma arké” (idem, p. 81). 
etapa inicial e também final tanto do processo amoroso quanto do processo poético, instrumento que possibilita o encontro entre "homem, terra e palavra".

Mesmo que entre encontros e desencontros, a chegada do amado e o despertar do desejo ainda são celebrados nos poemas seguintes, por meio da movimentação de outros signos centrais nesse livro ${ }^{96}$, como o da "ave", a "renascer da morte":

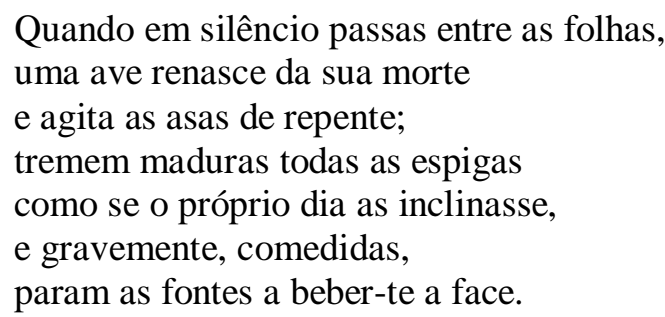

(ANDRADE, 1966, p. 19)

Comparado à força erótica do vento, cuja simbologia também remonta à lírica tradicional, o amado anima a paisagem, despertando a "ave" e desencadeando uma série de movimentos entre os elementos até impulsionar a mudança de ritmo da "fonte", que, por sua vez, em um gesto circular, colhe também a "face" do amado. Assim, em volta dos amantes e dos elementos da natureza circunda uma espécie de energia vital e unitiva que mimetiza o movimento cíclico do dia e da fonte. As imagens percorrem um fio analógico que mantém a circulação dessa energia por meio da transferência entre os signos. O poema evidencia a potência do amor e do desejo, forças que motivam as constantes transferências de um signo a outro e a proliferação de metáforas. Segundo Gastão Cruz, só o amor é capaz de "gerar essa indistinção máxima das coisas que alimenta a metáfora". Conforme explica o crítico, "perseguir uma imagem é sempre, para o autor de As mãos e os frutos, perseguir uma série de outras de que ela é metáfora ou que são metáfora dela" (CRUZ, 1971, p. 123).

A chegada do amado também é aludida por de uma "espécie de música"97 do vento nas folhas ou do ritmo da fonte (ainda que esta "música" também abarque o

\footnotetext{
${ }^{96}$ Embora a centralidade recaia em "mãos" e "frutos", presentes desde o título e o poema de abertura do livro, os signos "ave", "noite", "rio" e "fonte" também se repetem e percorrem núcleos expansivos, que, ainda que suscitem uma variedade de temas e assuntos, se encontram amarrados por um eixo comum: $o$ anúncio do "canto". No segundo livro da coletânea, Os amantes sem dinheiro, a "ave" constitui signo central, conforme analisamos na seção seguinte.

${ }^{97}$ Expressão de Óscar Lopes. Uma espécie de música - a poesia de Eugénio de Andrade. Porto: Campo das Letras, 2001. Muitos críticos assinalaram a correspondência entre música e poesia na obra de Eugénio de Andrade. Na ocasião da publicação de As mãos e os frutos, Vitorino Nemésio afirmou que o livro
} 
"silêncio" do amado e o "parar" da fonte). No emblemático segundo poema do livro, o "canto" também é desperto pelo amado e pressentido nos elementos: "Cantas. E fica a vida suspensa./ É como se um rio cantasse:/ em redor, é tudo teu;/ mas quando cessa o teu canto/ o silêncio é todo meu" (ANDRADE, 1966, p. 18). Tanto neste quanto no poema acima, os signos ficam a vibrar, em seu conjunto, contra o que pressentimos ser o silêncio anterior e posterior ao canto. O ritmo amoroso, que nasce do mover dos corpos, despertando o desejo, a alegria e os sentidos, vem confluir na "música" pressentida nos elementos da terra, nos frutos, nas aves, na água das fontes e dos rios. Encanta a linguagem, provoca o fluir contínuo de imagens, metaforizado neste segundo poema do livro pelo transcorrer do "rio", que, em todo o volume é comparado ao corpo do amado, como no verso "Impetuoso o teu corpo é como um rio / onde o meu se perde." (ANDRADE, 1966, p. 36), ou em "O seu corpo perfeito, linha a linha, / derramava-se no meu" (ANDRADE, 1966, p. 47).

No entanto, se o "canto" é aqui apenas apreendido, a partir do poema 6 ele passa a ser "fabricado" e evocado em primeira pessoa: "Não canto porque sonho. Canto porque és real. [...]/ Canto porque o amor apetece./ Porque o feno amadurece/ nos teus braços deslumbrados./ Porque o meu corpo estremece/ por vê-los nus e suados (ANDRADE, 1966, p. 22).

Do mesmo modo, o "fruto", antes recolhido nas mãos do amado, como no poema de abertura, surge, no poema 23, "Uma cerejeira em flor" (um dos poucos intitulados do livro), no mais pleno auge do processo de fabricação. Nesse poema, o "fruto", metáfora para a arte poética eugeniana, atinge o seu apogeu de plenitude e fertilidade:

deveria ser "folheado como uma partitura". No já citado "Uma espécie de música", talvez o mais penetrante ensaio sobre a poesia eugeniana, Óscar Lopes estuda as modulações rítmicas ditadas principalmente pelo que ele chama de "aceleração das metáforas" e processo de metamorfose, especialmente dos elementos fundamentais que os antigos distinguiam sob a forma de terra, água, ar e fogo - modos de transição que funcionam como "curvas de uma língua melódica": "E apetece logo caracterizar essa poesia como uma espécie de música, em que as próprias imagens, metáforas ou conotações verbais apenas entram como valores de composição, digamos que como notas integradas numa espécie de estruturas tonais, modais, seriais.” (LOPES, 2001, p. 63). Carlos Mendes Sousa também investiga em $O$ nascimento da música - a metáfora em Eugénio de Andrade as ocorrências dos termos "música", "cantar" e "canto" na obra eugeniana, e suas relações com a voz materna e o ímpeto erótico, embora o foco recaia sobre os livros posteriores. Coimbra: Livraria Almedina, 1992. 


\section{Uma cerejeira em flor}

Acordar - ser na manhã de abril a brancura desta cerejeira, arder das folhas à raiz, dar versos ou florir desta maneira.

Abrir os braços, acolher nos ramos o vento, a luz, o que quer que seja, sentir o tempo, fibra a fibra, a tecer o coração de uma cereja.

(ANDRADE, 1966, p. 42)

O que salta à vista neste poema é a fusão total - talvez semelhante àquela que o amor persegue - entre sujeito e objeto, corpo e mente, o agora e o sempre, as "mãos" e os "frutos". Obtém-se a almejada coincidência com a natureza: a "mão" dos primeiros poemas não só alcança como também se torna o próprio "fruto", porque, muito além de tocá-lo, lhe apreende a essência, participando da agoridade da vida que se percebe no “coração" da "cereja".

A predominância de sons abertos ao longo das estrofes, sobretudo da vogal "a", como em “acordar", “abril”, "brancura”, “arder”, “abrir”, “acolher” etc., produz o efeito geral de entrega e abertura - o sujeito abre os "braços" como a árvore alarga os ramos, para acolher os elementos e trabalhar o fruto - trabalho árduo que aqui também é intensificado pela repetição das combinações vibrantes de "abrir os braços" e "fibra a fibra", e depois pela aliteração no verso final "tecer o coração de uma cereja".

Por meio da relação metonímica, o poema compõe uma superimagem: a da árvore a fabricar o fruto, sobreposta à figura do poeta a erguer os braços ${ }^{98}$ e produzir versos. Ambas coincidem para gerar uma terceira relação de sentido: a imagem do próprio processo de composição da poética eugeniana, marcada pelos verbos "acordar", "ser", “arder", “dar", “florir", “abrir", “acolher", "sentir”, “tecer” - os quais possibilitam o cruzamento de campos semânticos referentes tanto ao homem, que "arde" e "sente", quanto à natureza, que "abre" o fruto e "floresce". Nesse poema, dá-se,

\footnotetext{
${ }^{98}$ Não podemos deixar de incluir a análise sutil e brilhante que Óscar Lopes faz dos "braços suspensos", imagem bastante recorrente na poesia eugeniana: " [...] Como se sabe, e por exemplo, a etimologia mostra, pensar é uma translação semântica de pesar (verbo), um conceito é algo de agarrado (em língua latina ou em alemão), e uma ideia, no seu grego originário, é algo que se vê. Ousar a metáfora de deixei no ar braços suspensos com a carga afectiva e semântica que adquire no contexto é, por isso, regressar a uma das fontes da função poética (por equivalência semântica) em dada fase importante na gênese das línguas modernas". Uma espécie de música. Porto: Campo das Letras, 2001, p. 128.
} 
portanto, o almejado encontro entre "homem", "terra" e "palavra" afirmado no prefácio "Poética", já que a superimagem final remete simultaneamente aos três universos propostos.

A identidade sonora entre "ser" e "CEReja", evocada também pela rima na segunda estrofe "seja"/ "cereja", aponta para a temática central desse poema que pretende revelar todo o empenho do ato poético para operar transformações e levar tanto o poeta, o poema, como o leitor a abandonarem o estado de inércia e dormência para o encontro com o "ser". Os verbos organizam-se no modo infinitivo: "acordar", "ser", etc., que, segundo Celso Cunha, é uma forma nominal caracterizada por não exprimir o tempo e o modo, ou seja, por evocar, antes, um estado, ou uma ação em curso: "O processo verbal em potência" (CUNHA, 1972, p. 330). Desse modo, os verbos no infinitivo, substantivados, definem a poética eugeniana em toda a sua busca e empenho. Revelam outra concepção do tempo, infinitamente em curso, como no verso: "O tempo a tecer o coração de uma cereja": infinita sucessão de instantes, mas que participam de modo global do ciclo da vida.

A realidade do "fruto" permite, assim, ao sujeito o despertar no seio do instante: "Coração inaudível de todas as coisas", como denominou Eduardo Lourenço, esfera "cujo centro está em toda parte e a circunferência em parte alguma" 99 . O instante é de difícil apreensão quando a vida se pauta pela lógica linear e progressista que determina os modos sociais modernos. No entanto, o instante somos nós mesmos: instaura a presença do "homem no homem" e permite vivenciar a realidade abrangente do mundo fenomênico. Ao ancorar-se no instante, as imagens do poema conseguem contornar a cisão que o tempo continuamente impõe. O homem desperta para o seu próprio ser através da vivência ontológica reinstaurada pelo próprio poema.

Nesse sentido, esse poema estabelece diálogo com diversas tradições. Por um lado, aproxima-se da visão atomista recuperada pelos epicuristas, em que o mundo é visto como um composto de unidades essenciais, gerado acidentalmente e de duração finita $^{100}$. De acordo com essa visão, é por meio da união e separação dos átomos que se dá a vida. Uma vez que a vida está em constante formação e transformação, a unidade,

\footnotetext{
${ }^{99}$ Expressão de Eduardo Lourenço em "Tempo e poesia”. Tempo e poesia. Lisboa: Gradiva, 2003, pp. 33 a 38.

${ }^{100}$ Cf. Julián Marías, História da filosofia. Porto: Edições Sousa \& Almeida, 1978, pp. 31 a 53; e Marilena Chaui, Introdução à história da filosofia. Vol 1. São Paulo: Companhia das Letras, 2002, pp. 119 a 129.
} 
por seu turno, é imutável. Assim, o "fruto", ou a "cereja", poderia ser lido como a unidade primordial: centro de convergência em que simultaneamente se pressente a origem e o fim dos tempos. O "tempo" "fibra a fibra" a tecer "o coração de uma cereja" nada mais é do que o trabalho da semente: fim do próprio fruto, mas também começo de outro, unidade primordial simultaneamente móvel e imóvel, "coração do instante" que avança em direção à morte ao mesmo tempo que a supera sempre ${ }^{101}$.

O gesto poético consagra, assim, o tempo de tudo, tempo único e arquetípico, presente absoluto que dissolve nossas ilusões de linearidade, pois isola o instante pleno da sucessão progressiva da história. $\mathrm{O}$ "coração da cereja" reenvia o sujeito à vivência simultânea de todas as coisas, alargando a percepção para a abrangência dos fenômenos.

O fenômeno poético, em suma, estabelece a relação de contiguidade entre todas as coisas, reunidas entre os três termos fundamentais almejados por essa poética: o poeta "arde" o poema "das folhas à raiz", "dá versos" como a árvore dá flor, "abre os braços" para acolher nos "ramos" o "vento e a luz".

A potência máxima do instante unifica tudo, mas também ocasiona o movimento de abertura inesgotável. O poema alcança a plenitude na própria provisoriedade da natureza, tão lamentada em outros poemas.

Em composições seguintes, o ciclo poético é aludido em termos de decadência, como nos versos do poema 34: "Como frutos de sombra sem sabor/ vamos caindo ao chão apodrecidos" (ANDRADE, 1966, p. 53). Ou no poema 33:

\begin{abstract}
A tua vida é uma história triste.
A minha é igual à tua.

Presas as mãos e preso o coração, enchemos de sombra a mesma rua.

A nossa casa é onde a neve aquece.

A nossa festa onde o luar acaba. Cada verso em nós próprios apodrece, cada jardim nos fecha a sua entrada.
\end{abstract}

(ANDRADE, 1966, p. 52)

\footnotetext{
${ }^{101}$ A "cerejeira" também remonta à simbologia oriental, em que a frágil flor representa a efemeridade da vida. A árvore na cultura japonesa associava-se à figura do samurai, cuja vida era tão breve quanto a flor que se desprendia. Pela cor e suculência, o fruto, por sua vez, evoca sensualidade, sendo comparado ao "primeiro gosto do amor". http://www.ehow.com/about_6507642_japanese-cherry-tree.html e http://www.britannica.com/EBchecked/topic/109522/cherry. Acessado em 7/ 12/ 2010.
} 
O sujeito lastima o retorno da "tristeza" e da condição de "sombra" anteriores à chegada do amante, cujas "mãos" no poema de abertura entrelaçavam "estrelas" nos dedos, mas que agora se fecham juntamente com o "coração", em interrupção do processo amoroso.

O amor não permite mais a condição de "entrega" em que se gerava o poema. Os versos "apodrecem" e a entrada ao "jardim" edênico, onde a "mão" alcançava o "fruto" do desejo e do conhecimento, é fechada. O instante de plenitude é breve, o amor e a poesia logo se esgotam.

Da mesma maneira, a "ave" e a "fonte" nem sempre encontram o fluir desejado, como no poema 5 do livro: "Nos teus dedos nasceram horizontes / e aves verdes vieram desvairadas / beber neles julgando serem fontes" (ANDRADE, 1966, p. 21). Se antes as mãos do amado traziam os frutos, no poema acima elas erguem "horizontes" que nem sempre se revelam férteis no encontro com a palavra poética, para a qual o voo do pássaro frequentemente aparece como metáfora. A cor verde das aves denota esperança; estas, porém, não encontram a fonte como no poema anterior - os termos "desvairadas" e "julgando" implicam equívoco e desilusão. No poema 16, os versos finais cantam o mesmo desencontro: "Suspensas as aves bebem o teu grito / e ficam cegas a tremer de frio" (ANDRADE, 1966, p. 34). No poema 24, a imagem do vento e da ave nas folhas do poema 3 transcrito acima é retomada. Porém, desta vez a energia circundante entre os elementos encontra-se já exaurida:

\begin{abstract}
Somos folhas breves onde dormem aves de silêncio e solidão.

Somos só folhas ou o seu rumor. Inseguros, incapazes de ser flor, até a brisa nos perturba e faz tremer. Por isso a cada gesto que fazemos cada ave se transforma noutro ser.
\end{abstract}

(ANDRADE, 1966, p. 43)

Se a movimentação final desse poema se assemelha ao "despertar da ave" e subsequente "agitar das asas" do poema 3, o voo aqui está envolto em tristeza. O sujeito lamenta a passagem do tempo. $\mathrm{O}$ canto de amor falha como alternativa à vivência estéril do homem moderno, incapaz de se reencontrar na unidade da natureza, "ser flor" ou fruto, como no poema "Uma cerejeira em flor". Tanto o amor quanto o fazer poético 
revelam-se efêmeros. A provisoriedade do instante aqui é trágica e dolorida, como revela a imagem final da dissolução dos gestos.

O tom trágico é constante na poesia de Eugénio de Andrade, prescrito por meio de signos obsessivos que expressam o esplendor do amor, da palavra e do ímpeto criador, para logo depois se esgotarem, revelando a insuficiência da linguagem poética. Como explica Octavio Paz em seu livro já citado, o amor, mesmo o mais feliz, é sempre uma experiência trágica, pois expõe os sujeitos ao tempo e a seus acidentes:

[...] A mudança, as paixões, a doença, a morte. Embora não nos salve do tempo, o entreabre para que, num relâmpago, apareça sua natureza contraditória, essa vivacidade que sem parar se anula e renasce e que, sempre e ao mesmo tempo, é agora e é nunca.

(PAZ, 1994, p. 101)

Ao fazer coincidir o amor e a poesia, Eugénio de Andrade expõe em termos trágicos o próprio alcance do fazer poético: pois é também a poesia que nos põe face a face com a morte. Também ela nos dá conta de nossa própria fragilidade. Tanto o amor quanto a poesia, se não permitem a aceitação da morte, ou se não a vencem, ao menos “integram a morte na vida", como tão bem disse Paz: "A luz é inseparável da sombra, o voo da queda" (PAZ, 1994, p. 133).

Contudo, em As mãos e os frutos, a arte poética eugeniana revela todo o seu ciclo constitutivo para também firmar, ao final desse primeiro volume, a vontade de perpetuar-se. No penúltimo poema do livro, Eugénio de Andrade canta:

Em cada fruto a morte amadurece,

deixando inteira, por legado, uma semente virgem que estremece logo que o vento a tenha desnudado.

(ANDRADE, 1966, p. 54)

Se pressentimos no decorrer do livro o lamento em relação ao esgotamento do amor, esse poema reafirma, por outro lado, a força erótica e o desejo como potências inesgotáveis geradoras do poético. A poesia é apresentada como possível resistência à 
morte, devido à sua capacidade de transformação, aqui ressaltada. ${ }^{102}$ De modo semelhante, no último poema do livro, embora prevaleça o tom trágico com que o sujeito isolado lamenta uma noite escura e "molhada" de lágrimas, a última estrofe reforça a mesma luz-esperança das "sementes": "Ó noite eterna e velada /, senhora da tristeza, sê alegria! / Vem de outra maneira ou vai-te embora, / e deixa romper o dia!" (ANDRADE, 1966, p. 56). ${ }^{103}$

Todo o livro As mãos e os frutos reunido poderia quase compor um longo e único poema, conforme comenta José Bento ${ }^{104}$. Com efeito, o mesmo ciclo do "fruto", evocado desde o poema de abertura, narra histórias de "amor" e "aventura poética" que se entrecruzam e se determinam ao longo de todo o livro. Do "germinar" ao lento processo de "maturação" do fruto, perseguimos também o movimento de instauração e perda do universo paradisíaco, em que o sujeito procurava vivenciar a plenitude do amor e da poesia, mas se deparava, ao mesmo tempo, com a brevidade de ambos perante as condições humanas mais duradouras de isolamento e ausência. Todavia, os últimos poemas do livro reafirmam novas esperanças ao desprenderem a "semente" do “fruto" já "apodrecido", apontando principalmente para a capacidade metamórfica dessa poesia.

Temos, em suma, que Eugénio de Andrade recorre à metáfora orgânica do "fruto" para definir sua arte poética nesse primeiro livro. Conforme observamos, o

\footnotetext{
102 "Resistir" não implica vencer aqueles que são talvez os maiores enigmas do homem: a morte e o tempo, mas oferecer, através do empenho poético, alternativas para encará-los de frente, como escreveu Octavio Paz em seu livro já citado: "Somos tempo e não podemos nos abstrair de seu domínio. Podemos transfigurá-lo, não negá-lo nem destruí-lo. Isso é o que fizeram os grandes artistas, os poetas, os filósofos, os cientistas e alguns homens de ação. O amor também é uma resposta: por ser temporal, o amor é simultaneamente consciência da morte e tentativa de fazer do instante uma eternidade." (PAZ, 1993, p. 189). Por conseguinte, a afirmação de Óscar Lopes de que a poesia eugeniana ofereceria a negação da morte, já que ela nem sequer a encara ou a reconhece ao se fazer "contra a evidência quotidiana da morte, da extinção de outros corpos degradados, contra a antecipação da própria extinção do sujeito" (LOPES, 2001, p. 120), parece-nos, talvez, excessiva, ainda que em outro trecho ele atenue a afirmação: "[...] A plenitude é vibratória, contém sinusoidalmente o seu oposto, e se consegue através de um trabalho exercido sobre aquilo que não está consumado, sobre aquilo que não satisfaz, e é quase tudo" (Idem, p. 151). Assim, nessa poesia cada celebração do instante condensa uma atitude dialética em relação à passagem do tempo. Se os poemas, por um lado, enaltecem em seu próprio tecido a impermanência da vida, por outro, revelam nossos mais profundos medos diante de toda mudança.

${ }^{103}$ Trataremos mais especificamente da relação entre a escrita eugeniana e os signos "noite" e "dia" na análise do quinto livro da coletânea, Coração do dia.

104 "Mais do que um livro de poemas chamarei a As mãos e os frutos um poema: sucessivos movimentos unificados por uma procura apaixonada da linguagem que os transfigure, uma contemplação tão longa que se vai desdobrando em sucessivas visões, um conhecimento de tudo, ora extasiado e jubiloso, ora reflectido e melancólico, que penetra a noite e a morte." Em "Poemas de Eugénio de Andrade". 21 ensaios sobre Eugénio de Andrade. Porto: Editorial Inova, 1971, p. 309.
} 
poema "Uma cerejeira em flor" aproxima metonimicamente a figura do poeta à imagem da árvore da cerejeira, a erguer seus "braços" como "ramos", dar "versos ou florir", e em uníssono, sentir seu coração bater ("tempo fibra a fibra") no fruto da cereja. Ditado pelo tempo natural está também, portanto, o lento trabalho do poeta, de "florir" e "dar frutos" como a cerejeira. O poema alude às motivações do poético, metaforicamente expressas como "vento, luz, o que quer que seja", bem como expõe suas estruturas: "folhas, flor, fruto, raiz".

Se, desde os primórdios da poética ocidental, a tendência estrutural esteve presente na abordagem da literatura, como explica Dolezel, ao remeter o modelo mereológico $^{105}$ à Poética de Aristóteles, foi durante o período do Romantismo que o modelo orgânico se estabilizou, oriundo da filosofia e das ciências naturais. Como um trabalho importante e de grande influência, Dolezel cita a morfologia de Goethe das ciências naturais ${ }^{106}$ - e só posteriormente aplicada à poética. De acordo com o crítico, a morfologia de Goethe representou uma tentativa consistente de compreender a natureza viva tanto em sua abundante variedade quanto em sua unidade estrutural (1990, p. 102). Em seu modelo, a metamorfose é a força motora de qualquer mutação estrutural na natureza, geradora da "variedade individual dentro do proto-tipo invariante" (1990, p. 100). Assim, Goethe estabelece seu sistema a partir de três conceitos básicos: estrutura, proto-tipo e metamorfose: a vida da natureza consistiria, assim, "na decomposição da unidade e na unificação das partes divididas; [...] uma eterna sístole e diástole, uma eterna síncrese e diacrese; a inspiração e a expiração do mundo no qual vivemos, elaboramos e existimos" (DOLEZEL, 1990, p. 96).

Se antes a estrutura era definida como um conceito estático, fechado, fixo em seu caráter, a partir do modelo morfológico de Goethe ela adquire dinamismo. Mais

\footnotetext{
${ }^{105}$ A mereologia constitui-se como um ramo da lógica e da filosofia que estuda a relação entre as partes e o todo. Por "modelo mereológico" entende-se a "expressão teórica" do "conceito de literatura como estrutura", tão antiga quanto o envolvimento do Ocidente com a literatura, conforme explica Dolezel, sendo a sua primeira versão o modelo aristotélico da tragédia, que seguia os postulados gerais da teoria aristotélica da ciência (DOLEZEL,1990, p. 18).

${ }^{106}$ Durante a juventude, Goethe dedicou-se ao estudo da medicina e das ciências naturais na Universidade de Leipzig, e ao longo de toda a vida, manteve, paralelamente à atividade literária, pesquisas científicas, aprofundando seus conhecimentos de mineralogia, anatomia e botânica. Em 1786, Goethe realizou uma longa peregrinação pela Itália, dando início a uma extensa coleta de dados sobre botânica. Conforme descreve Alberto Martins, foi no ano de 1787, durante a viagem, que Goethe teve, nos jardins das plantas de Palermo, a intuição da Urpflanze: a "planta original". Após o retorno à Alemanha, entre 1788 e 1789 , o autor se dedica à escrita do ensaio "Metamorfose das plantas". Em 1816, publica a primeira edição de Viagem à Itália e lança a revista Zur Naturwissenschaft überhaupt, besonders zur Morphologie, na qual publica muitos ensaios científicos. Introdução de Viagem à Itália (1786-1788). Trad. Sérgio Tellaroli. São Paulo: Companhia das Letras, 1999.
} 
tarde aplicado à poética por Humboldt, o modelo orgânico aproximou a metamorfose ao processo da imaginação, que transforma a natureza ao transpô-la para a poesia:

A partir do material da natureza, a imaginação do poeta "constrói (erzeugt)" um objeto "ideal" 107 e dota-o de propriedades que podem corresponder, mas não necessariamente, às propriedades desse material da natureza. No final, o "domínio da fantasia" construído é contrastado não só com o "domínio da realidade", mas também com o domínio dos conceitos. Este caráter específico das obras de arte é reforçado.

(DOLEZEL, 1990, p. 110).

Assim, Humboldt declarava que enquanto no domínio da realidade há um aglomerado de objetos não estruturados, o domínio da imaginação é articulado por construtos holísticos, inter-relacionados, que só poderiam ser analisados e compreendidos por meio de um modelo mereológico, que conseguiria apreender tanto a individualidade artística de uma obra quanto sua forma proto-típica.

A ideia de que a obra é "um todo vivo" permaneceu ativa durante o Romantismo, só vindo a ser questionada no século $\mathrm{XX}$, com a instituição do modelo semiótico, que coincidiu com o surgimento da linguística como disciplina, e reconheceu, segundo o crítico, a natureza metafórica da representação orgânica. ${ }^{108}$

Porém, a concepção orgânica sobreviveu como uma espécie de intertexto recuperado pelos formalistas russos, que, de acordo com Dolezel, representaram "o culminar da poética morfológica do século XIX [...] e, simultaneamente, o desenrolar dos princípios teóricos fundamentais do estruturalismo do século XX” (1990, p. 201). Os formalistas russos estabeleceram uma morfologia dos proto-tipos, executando o projeto inicial de Goethe de transpor seus achados para o estudo da poética. ${ }^{109}$

Eugénio de Andrade recupera a metáfora orgânica para definir sua poética, não só pelo fato de arquitetá-la em correspondência com o processo de maturação do fruto, mas também por remeter a uma rede complexa de unidades poéticas organicamente estruturadas, procurando distinguir suas principais motivações, estruturas e forças

\footnotetext{
${ }^{107}$ Dolezel faz uma ressalva quanto ao termo "ideal": utilizado por Humboldt para designar construtos mentais e não no sentido de "natureza idealizada" (1990, p. 110).

${ }^{108}$ Segundo Dolezel, reconheceu-se que os sistemas de significação operam de maneira diferente dos sistemas biológicos, já que os signos são representações. Embora os postulados da mereologia fossem incorporados pelo modelo semiótico, o modelo orgânico foi relegado a segundo plano dentro do estudo da poética (1990, p. 159).

${ }^{109}$ Referência, sobretudo, ao trabalho de Vladimir Propp.
} 
motoras. Assim como o fruto que trabalha a semente, sua poética também almeja transfigurar o elemento transitório em energia permanente.

A ênfase que Eugénio de Andrade procura dar, dessa maneira, é no caráter de constante alteração das unidades poéticas, pertencentes a um domínio essencialmente instável, delineado por constantes deslocações dentro de uma complexa rede de referenciais. O modelo orgânico pode oferecer, assim, a vantagem de dar a conhecer os constituintes mínimos e as forças germinadoras do poético, os quais, em constante transformação, nos conduzem ao horizonte infinito de novas substâncias.

Dessa maneira, embora a força-formante do amor e do fazer poético em As mãos e os frutos se esgote e seja lamentada de maneira bastante trágica, a incessante procura pelo poético mantém-se, como podemos ler não só na metáfora da semente, mas também nos versos do poema 30: "Onde me levas, rio que cantei / esperança destes olhos que molhei [...] / Não quero que conduzas ao silêncio / de uma noite maior e mais completa [...] / Canção: vai para além de quanto escrevo / e rasga esta sombra que me cerca." (ANDRADE, 1966, p. 49), assim como nos versos finais do livro, já transcritos acima: "Ó noite eterna e velada, [...] / Vem de outra maneira ou vai-te embora, /e deixa romper o dia!” (ANDRADE, 1966, p. 56). Nos livros seguintes, essa procura será marcada por meio de novos referentes e mecanismos.

\title{
3.3 O tempo puro das "aves"
}

\author{
O amorl é uma ave a tremer \\ nas mãos de uma criança. \\ (Eugénio de Andrade, 1966, p. 74) \\ O poema é, ele também, como o Pássaro \\ que vibra na eternidade cantante. \\ (Gaston Bachelard, 1990, p. 80)
}

Em Os amantes sem dinheiro (1947-1949), segundo livro da coletânea, alguns dos signos presentes em As mãos e os frutos surgem redispostos em novos núcleos significativos. Assim, o "ciclo do fruto" é logo evocado no poema de abertura do livro: 


\section{Conselho}

Sê paciente; espera

que a palavra amadureça

e se desprenda como um fruto

ao passar o vento que a mereça.

(ANDRADE, 1966, p. 63)

Em contraste com a exaltação do poema de abertura do livro anterior, em que o eu lírico estendia as mãos em atitude quase desesperada para colher os "frutos" nos dedos do amado, a poética desse segundo livro é aqui estabelecida em termos de "espera" e "entrega": condições para que a palavra se desprenda e, como o "fruto", realize a promessa de amor e de poesia. A ênfase recai sobre seu curso de "amadurecimento", ou seja, diante da passagem do tempo, aconselha-se "paciência" para que o poeta possa perscrutar o lento trabalho da palavra. Nesse segundo livro, portanto, serão distinguidos e explorados os processos constitutivos ligados, principalmente, ao papel do tempo e da memória no fazer poético. ${ }^{110}$

Desse modo, se o amado trazia os "frutos" e a entrada para o jardim paradisíaco no livro anterior, nesse volume o acesso ao "jardim do poema" associa-se também ao ato de rememorar:

\section{Imagem}

A lembrança do dia é leve de se ter: garganta de um jardim, só aroma ao descer.

(ANDRADE, 1966, p. 73)

Ou como também no poema "Improviso para uma fonte", quinto do livro: "Boca da terra. / Ao longe pressentida / mas discreta. /A quem te procura / entregas-te aberta." (ANDRADE, 1966, p. 68)

A partir do prefácio, no qual o poeta dedica o livro à mãe, ${ }^{111}$ notamos a ênfase

\footnotetext{
${ }^{110}$ Em As mãos e os frutos, a "espera" também é marcada em diversos momentos, como no quarto poema do livro: "Somos como árvores/ quando o desejo é morto. [...] / Só então, belos e despidos, / ficamos longamente à sua espera" (1966, p. 20), ou no poema "Espera": "Aqui onde o exílio / dói como agulhas fundas, / esperarei por ti” (1966, p. 50). No entanto, a espera é, nesse primeiro livro, sempre melancólica e angustiante, vivida como desgaste da relação amorosa. Em Os amantes sem dinheiro, por outro lado, o processo de espera é examinado sob outra perspectiva, em direta associação com a memória e o processo poético. O sujeito solicita a si mesmo, portanto, "paciência", no poema de abertura do livro.

${ }^{111}$ Escrito em prosa poética e autobiográfica, o prefácio explora a relação com a figura materna e o trecho
} 
sobre as lembranças da infância e o propósito de investigar a relação com a figura materna e com os primeiros ímpetos poéticos. Dessa maneira, o prefácio narra como se deu o nascimento da palavra desde a primeira infância em que o poeta vivia na "casa do Adro" e na "casa da Eira" ${ }^{112}$ :

É todo um mundo confuso, de penetração difícil, tanto mais difícil quanto mais pretendo pô-lo claro, transparente. Não sei se houve primeiro lágrimas ou o som do harmónio. Em todo o caso lembro-me de duas casas - uma na Eira, outra no Adro. Sei que as lágrimas e as estrelas eram na casa da Eira e a música do harmónio na casa do Adro.

(ANDRADE, 1966, p. 59).

Se no primeiro livro eram as mãos do amado que traziam "estrelas" penduradas nos dedos, imagem luminosa vinculada ao fazer poético, neste prefácio ela reaparece ligada às lembranças da infância. Assim, em cada casa, o menino experimentou origens possíveis para a palavra poética: na primeira encontrou a música (o "som do harmónio" e o "cantar da mãe", como mencionado em outro trecho do prefácio), e na segunda se deparou com as "lágrimas" de separação em relação à mãe, metaforizadas em "estrelas":

Ó mãe, mãe... Mas a mãe não vinha. Não havia mãe. Havia só a porta fechada - Ó mãe, mãe... - E a casa deserta. Pelas frinchas largas da porta via a manhã lá fora. Era uma manhã de sol quente, talvez de julho, talvez de agosto. Devia haver medas de pão na eira em frente. Mas os meus olhos mal viam, estavam rasos de água e de angústia. Ó mãe, mãe ... - E de repente, na manhã clara, começaram a cair estrelas pequeninas, estrelas verdes, vermelhas, estrelas de oiro. As lágrimas caíram-me pela cara - Ó mãe, mãe... [...] E ninguém me abriu a porta para apanhar as estrelas. Nem mesmo tu, mãe, que a essas horas andavas a ganhar o pão para a boca daquele que hoje te oferece esses versos.

(ANDRADE, 1966, p. 61).

final apresenta-lhe dedicatória: "E ninguém me abriu a porta para apanhar as estrelas. Nem mesmo tu, mãe, que a essas horas andavas a ganhar o pão para a boca daquele que hoje te oferece estes versos" (ANDRADE, 1966, p. 62). A dedicatória lança mão da imagem sugestiva da mãe a alimentar a "boca" que produz os versos, ou seja, aponta para a correlação entre a figura materna e a poesia, trabalhada ao longo de todo o volume.

112 Eduardo Lourenço aproximou o signo da "casa" - que aparece repetidamente na obra de Eugénio de Andrade - do lugar de sua aventura poética (1971, p. 46), como denota o poema "Metamorfoses da casa", de Ostinato rigore: "Ergue-se aérea pedra por pedra / a casa que só tenho no poema. / A casa dorme, sonha no vento / a delícia súbita de ser mastro. / [...] Ah, um dia a casa será bosque, / à sua sombra encontrarei a fonte / onde um rumor é só silêncio" (ANDRADE, 1966, p. 222). 
A partir do prefácio, a origem da palavra poética será referida por todo o livro em termos de luminosidade: "manhã clara", "estrelas de oiro", "manhã feliz e descuidada", "manhãs mais limpas", "lume”, "no teu rosto começa a madrugada", "luz abrindo", "ardor do sol", "luz tropeçando nas esquinas"; "olhos de oiro"; "milagre de cada dia escorrendo pelos telhados". Outras vezes, a origem da palavra será referida em termos de música, como "som do harmónio", "ciganos a cantar", "assobio", "uma mulher a cantar", "rumor", "melodia distante mas segura”, "noites rumorosas de águas matinais".

Eis as unidades elementares, luz (imagem) e som, que, durante a gênese da palavra, se encontram ainda apartadas. No prefácio do livro, o poeta distingue as unidades no momento imediatamente anterior à união vigorosa que ambas realizam para formar o substancial de sua poesia. Em composições seguintes, observamos esse mesmo movimento reverso, em que o poema se desdobra à origem a fim de distinguir as suas unidades elementares e talvez investigar, como pretendemos demonstrar, certas representações da memória, em suas ligações com o fazer poético.

Desse modo, a sensação de perda em relação à mãe é já marcada no prefácio e se tornará uma constante no transcorrer de todo o livro, assim como a referência à "pobreza", que nesse texto de entrada é sugerida pela descrição da "arca velha" como tudo aquilo que mãe e filho tinham, a exalar "um cheiro forte" de "frutos naturais que a terra dá" (ANDRADE, 1966, p. 60). Se a pobreza é material, como também indica a expressão "sem dinheiro" do título do livro, a vida simples do campo, arraigada à terra, representa, em contrapartida, uma fonte infindável de riquezas para o ser e para a poesia, ainda que toda a plenitude seja pressentida no tempo provisório da natureza. Por conseguinte, o sujeito se encontra constantemente rodeado pela sensação de falta e de ausência - sobretudo da figura materna nesse segundo livro. Mas é essa profunda condição de falta e de fragilidade que operará o "milagre" de sua poesia, em que as "lágrimas" e a "angústia dos olhos rasos de água" são transubstanciadas na "manhã clara" e na luz das "estrelas de oiro", erguidas pela irrupção da poesia. A palavra querendo nascer é, pois, um momento difícil, um "rumor" que ainda é silêncio, emergindo de conflitos longamente sentidos pelo poeta, entre plenitude e ausência, entre o indizível e o dizível. 
No poema homônimo ao livro, imediatamente posterior a "Conselho", encontramos novamente alusões às condições ideais para que a palavra nasça:

\section{Os amantes sem dinheiro}

Tinham o rosto aberto a quem passava.

Tinham lendas e mitos e frio no coração.

Tinham jardins onde a lua passeava

de mãos dadas com a água

e um anjo de pedra por irmão.

Tinham como toda a gente

o milagre de cada dia

escorrendo pelos telhados,

e olhos de oiro

onde ardiam

os sonhos mais tresmalhados.

Tinham fome e sede como os bichos, e silêncio

à roda dos seus passos.

Mas a cada gesto que faziam

um pássaro nascia dos seus dedos

e deslumbrado penetrava nos espaços.

(ANDRADE, 1966, p. 64)

O primeiro verso ("Tinham o rosto aberto a quem passava") repete os estados de "entrega" e de "espera" determinados pelo poema de abertura do livro, como condições para uma poética de Os amantes sem dinheiro. O verbo indicador de posse "tinham", no começo de cada verso, assinala o acúmulo das descobertas e dos sonhos, e prescreve o tom de plenitude vivida pelos amantes do poema. As circunstâncias para que a palavra "amadureça" e "se desprenda" estão presentes: "rosto aberto", "lendas e mitos", jardim paradisíaco onde tudo se une em elo mágico: "a lua passeava de mãos dadas com a água", "anjo de pedra por irmão". Novamente, na contramão do que comumente se toma como miséria ou privação, como indicam a expressão "sem dinheiro" do título e os versos "fome e sede como os bichos" e "silêncio à roda de seus passos", o poema revela a imensa riqueza que rodeia os amantes, reconhecendo no amor e no elo com a natureza a origem de toda verdadeira abastança - do mesmo modo que a "arca velha" da mãe e do menino era, no prefácio, comparada a um tesouro. Logo, é desse universo 
de encantamento e união com a natureza que desponta a poesia, metaforizada no poema pela imagem do "pássaro" a se levantar dos "dedos".

A entrega é total e sua realização, tanto no amor quanto na poesia, é violenta e causa, ao final do poema, desestruturação e abertura. A imagem do pássaro poderia aludir à substancialidade da poesia, mas também à sua natureza transitória e metamórfica. A palavra amanhece, mas também já parte. O amor é pleno, ainda que fugaz. O tempo despede-se, mas o céu aberto pelo poema aspira talvez à permanência. O espaço alargado instaura o mistério da palavra e o mistério de nós mesmos, pois nos remete a um sentido mítico, de memória primordial e nostalgia da unidade.

Roberto Calasso, em referência ao culto da forma - ainda que praticado muito posteriormente no Ocidente ${ }^{113}$ - narra, em A literatura e os deuses, um mito oriental pertencente ao Satapatha Brahmana que traça um movimento semelhante ao da ave nesse poema de Eugênio de Andrade. Os risi, videntes védicos que compuseram os Rigveda, contam no mito que os deuses eram gratos aos metros por estes tê-los envolvido em seu manto e os protegido contra o fogo. Gayatri, o mais eficaz dos metros, transformou-se em pássaro e subiu aos céus para roubar a soma, substância da imortalidade, e trazê-la aos deuses. Desde então, para os homens, aos quais sempre é mister imitar os deuses, os metros são mensageiros que transportam os sacrifícios aos deuses e sobem aos céus para alcançar a fonte da imortalidade. (CALASSO, 2004, p. 105)

Uma leitura possível para "ave"" seria a de que ela é uma representação arquetípica da forma "absoluta": aquela que introduz o gesto original de a toda poesia,

113 Roberto Calasso refere-se à tradição do culto da forma no Ocidente, que remonta aos poetas românticos alemães, entre eles Schlegel, Novalis, Heine e Hölderlin; incluindo nomes como o de Coleridge e também dos franceses Mallarmé, Baudelaire e Verlaine. Sobre essa tradição, Roberto Calasso trabalhou a definição de seu conceito de "literatura absoluta": "Literatura porque se trata de um saber que se declara e se pretende inacessível por outra via que não seja a da composição literária; absoluta porque é um saber que corresponde à busca de um absoluto - e, por isso, não pode comprometer nada menos do que o todo; e, ao mesmo tempo, é algo de ab-solutum -, "dissolvido" de qualquer vínculo de obediência ou pertença, de qualquer funcionalidade a respeito do corpo social". A literatura e os deuses. São Paulo: Companhia das Letras, 2004, p. 120. Embora o conceito implique dificuldades na sua compreensão histórica, o autor observa que, desde 1798, data da revista Anthenaeum, para a qual contribuíram autores como Schlegel e Novalis, até 1898, ano da morte de Mallarmé, a "literatura absoluta" manifestou-se em todas as suas características, e, a partir de então, "por todo um outro século, iriam se entrelaçar e hibridar inúmeras ramificações, repercussões e extensões a novos ambientes" (2004, p. 121).

${ }^{114} \mathrm{O}$ voo final da ave dissolve o esquema estrófico do poema e a palavra poética é posta em liberdade, lançando-se para além do jugo da frase, sempre a serviço de uma dada unidade de sentido. Desse modo, em máxima abertura imagética, multiplicam-se as potencialidades de sentido, já que a palavra recupera seu estado ambíguo original. Por isso, qualquer investida interpretativa para a "ave" nesse poema corre o risco de reduzir sua pluralidade essencial. No entanto, traçamos aqui algumas possibilidades, sem deixar 
ao mesmo tempo que expressa o gesto singular de cada poema. Pássaro a voar em direção a um horizonte em expansão poderia figurar o abrir para o absoluto que qualquer estrutura rítmica aspira, tanto na poesia quanto nos rituais antigos, em que o ritmo, a dança e a reza ensaiavam a re-ligação do homem com o Universo.

A “ave” é signo central, não só em termos quantitativos - do total de vinte e três poemas, ela é a imagem que mais aparece, distribuída em oito composições na extensão de todo o volume ${ }^{115}$-, mas também pela relevância dentro daquele que identificamos como núcleo decisivo do livro: a relação com o passado e com a figura da mãe.

Ainda que esse poema principal não se refira diretamente ao problema da relação materna, o tratamento que ele reserva ao amor repercute, de certo modo, o universo de plenitude (e ausência já pressentida) que o menino conhecera na infância, como pudemos analisar no prefácio desse segundo livro. Em primeiro lugar, o título do poema e o verso já referido "tinham fome e sede como os bichos" remetem à condição de pobreza também descrita no prefácio, em que mãe e filho habitavam, como vimos, "casitas" ("onde eu e a mãe começámos a ser um do outro") "mais pequenas ainda do que certas salas de brinquedos que os meninos ricos têm na cidade" (ANDRADE, 1966, p. 59). Da "arca" velha, único pertence onde "arrumam os pobres tudo o que têm", o menino retira um harmónio: "E então o que aconteceu foi maravilhoso: de dentro saiu um som bonito, mais bonito ainda do que a voz da minha mãe”. (ANDRADE, 1966, p. 60) É também da arca que o menino sentia um cheiro forte de "frutos naturais": elemento vinculado, assim como a música do harmônio, à poética eugeniana.

De maneira análoga, no poema "Os amantes sem dinheiro", se a ligação com a natureza é tudo que os amantes ("como toda a gente") possuem, é dessa aparente

de considerar que a poesia eugeniana faz coincidir, na própria palavra poética, todo o teor referencial com investidas críticas. Assim, mesmo quando uma imagem reflete sobre si mesma, quando ela é consciência do canto, jamais deixa de remeter a significados particulares ou referenciais, já que toda palavra também é sempre histórica e relativa.

${ }^{115}$ A "ave" aparece nos seguintes poemas do livro: 2, 9, 11, 13, 15, 17, 19 e 20. Em virtude de sua recorrência em toda a poesia de Eugénio de Andrade, João de Mancelos escreveu: "Mais do que qualquer outro poeta português, este é o escritor das aves. [...] De ramo em ramo, de canto em canto, de poema em poema, estes pássaros personificam qualidades, muitas vezes nobres, e assumem diversos cambiantes de pureza e desejo. $\mathrm{O}$ autor lê, na migração das aves, um reflexo da efemeridade, ou um desafio à morte, pela renovação da natureza; equipara o canto do pardal e de outros pássaros à palavra renovadora do poeta; aprecia a sabedoria da águia, cegonha e falcão; compraz-se com a beleza dos cisnes; deleita-se com o canto do melro". "Notas para o canto das aves em Eugénio de Andrade e em três poetas clássicos ingleses". Em $O$ marulhar de versos antigos - a intertextualidade em Eugénio de Andrade. Lisboa: Edições Colibri, 2009, p. 16. No presente livro, a ave, algumas vezes, assume a forma de uma "gaivota", como veremos adiante. Talvez por seu canto aflito, a gaivota encontra-se, mais frequentemente, rodeada de melancolia, em associação ao que parece ser lembranças tristes. 
pobreza que se desprende "o milagre de cada dia" a fabricar "os sonhos mais tresmalhados" e os "gestos" que impulsionam "aves" a tomar o espaço. A ação conjunta desse gesto amoroso, lido como motivação do poético, pode abarcar tanto a relação entre os "amantes" (de cujos dedos entrelaçados nasciam "estrelas" no primeiro livro), quanto a relação com a mãe (também geradora de "estrelas", como vimos no prefácio). ${ }^{116}$ Assim, ainda que esse poema possa ser compreendido como uma forçaforma singular e autônoma, e não demande necessariamente que seja inserido dentro dos núcleos trabalhados por Eugénio de Andrade, fica claro que a relação eu-tu nessa poesia é, de modo geral, bastante complexa, principalmente quando correlacionada ao problema do fazer poético, como parece ser o caso nesse poema. A clave amorosa na poesia eugeniana frequentemente compreende o problema do poético e remete a uma teia de motivações que o poeta desfibra no percurso dos poemas a fim de pensar o próprio trabalho.

É nesse sentido que o signo da "ave" se torna bastante significativo nesse livro, já que, como o "fruto" ou as "mãos" no livro anterior, é elemento de mediação das profundas contradições vividas por essa poesia: entre o universo de plenitude e falta, entre o passado e o presente, entre o dizível e o indizível, entre a origem e o próprio alcance da palavra poética. Já no primeiro livro, As mãos e os frutos, como vimos, a "ave" figurava o canto amoroso, desde o esplendor da chegada do amado, em que ela renascia da "morte" e "agitava" "as asas de repente" (1966, p. 19), até o engano e a frustração das "aves verdes desvairadas" a rondar os dedos do amado (1966, p. 21), “suspensas, cegas a tremer de frio" (1966, p. 34). Nesse segundo livro, a "ave" também remete à palavra poética, mas seu voo desliza agora por novas redes de sentido, já que a poética eugeniana procura abordar novos dilemas. Inserida agora em um núcleo poético diferente, que procura abordar o problema da figura materna como influência sobre o cantar eugeniano, a "ave" parece narrar uma espécie de transferência, ou seja, possibilita a permuta no jogo de influências determinantes dessa poesia, rasurando o

\footnotetext{
116 Os "olhos de oiro" do poema também lembram as "estrelas de oiro" ou "lágrimas pela cara" do prefácio, assim como o verso "milagre de cada dia escorrendo pelos telhados" sugere analogia com "De repente, na manhã clara, começaram a cair estrelas pequeninas" que o menino presenciara na "casa da Eira" (ANDRADE, 1966, pp. 61 e 62). Em El agua y los suenõs, Gaston Bachelard faz uma aproximação bastante pertinente para compreendermos o tratamento abrangente dado pela poesia eugeniana ao amor: "Todas las formas de amor reciben um componente del amor por uma madre". México, D.F.: FCE, 2005, p. 152; o filósofo ainda reconhece no sentimento da natureza o amor filial: "Comenzamos por amar la naturaleza sin conocerla, sin verla bien, realizando en las cosas un amor que está fundado en otra parte. Y si el sentimiento por la naturaleza es tan durable en ciertas almas es porque, en su forma original, está en el origen de todos los sentimientos. Es el sentimiento filial” (BACHELARD, 2005, p. 151).
} 
"retrato" que a mãe e o filho guardavam do passado, como veremos adiante. É mediadora, portanto, de uma profunda transformação na poética eugeniana.

Assim, ela reserva alto grau de ambiguidade: por um lado, é uma imagem que sugere instabilidade e imprevisibilidade, cujo voo desintegra o instante paradisíaco vivido pelo eu lírico, sugerindo a passagem do tempo, como também no poema "Quase nada", 11 do livro: "O amor / é uma ave a tremer / nas mãos de uma criança. Serve-se de palavras / por ignorar / que as manhãs mais limpas / não têm voz" (ANDRADE, 1966, p. 74), em que novamente se coloca o problema da fragilidade do amor e da palavra poética. E por outro, amplia as disponibilidades de sentido, por meio da suspensão da sintaxe linear ${ }^{117}$ e da desarticulação dos versos, criando uma espécie de intervalo, espaço de criação que se propõe ao leitor. Ao ocasionar abertura, sugere a máxima realização da poesia, movimentando e projetando suas unidades essenciais ao infinito.

Através de sua natureza imprecisa e nebulosa, que parece condensar uma série de associações e conteúdos subliminares, os quais poderiam remontar a significações míticas presentes na constituição e memória da própria linguagem, a imagem da ave estimula a fantasia mitopoética, e o gesto dos amantes acima parece imitar o gesto arquetípico de criação que todo mito esboça. ${ }^{118}$ Ao desarticular-se do verso, o voo da ave no poema "Os amantes sem dinheiro" estimula no leitor uma dada sensibilidade, um modo de "apreensão mental" que se distancia da lógica discursiva, em que os conceitos se concatenam de modo coordenado, em direção a um sistema fechado de concepção sintética. ${ }^{119}$ A imagem, ao se desprender, reclama autonomia, demandando uma atenção

\footnotetext{
${ }^{117}$ Sobre esse verso, escreveu Eucanaã Ferraz: “Também aqui há leveza e o desdobramento de um corpo noutro corpo. Também aqui há a abertura para um processo inconcluso e plural. $\mathrm{O}$ que chamei de porosidade é essa capacidade de penetração, de desdobramento, de movimento, de ascensão e voo. Aeração da escrita: que se abre em elipses tão sutis que mal percebemos o vazio (o silêncio, o ar) entre um e outro signo, uma e outra significação. [...] Sua leveza, repito, está em grande parte nesta capacidade de abolir a lógica (e a física e a química...) convencional, ao insuflar no espaço fronteiriço entre os seres e o ar os fizesses livres para uma nova articulação, para uma nova sintaxe, compreendida então como um posicionamento ontológico para além de linguístico, e físico, para além de ontológico". "Eugénio: animal amoroso". Revista Relâmpago, n. 15, 10/2004, p. 29.

${ }^{118} \mathrm{Na}$ definição de Mircea Eliade, o mito sempre narra um evento primordial, proclamando o advento de uma nova situação cósmica. Portanto, o mito é sempre a história de uma criação: "It is always, therefore, a story of a "creation""; "Herein resides the great secret of myths: they incite man to create". "The prestige of the cosmogonic myth". Em Myth: critical concepts in literary and cultural studies, edited by Robert A. Segal. Vol. IV, New York: Routledge, 2007, pp. 14 e 19. André Jolles também define o mito como potência criadora: "Mito é criação. [...] O mito é o lugar onde o objeto se cria a partir de uma pergunta e de uma resposta; por outras palavras: o mito é o lugar onde, a partir da sua natureza profunda, um objeto se converte em criação". Formas simples. São Paulo: Cultrix, 1976, p. 91.

119 Sobre as relações entre linguagem e mito e o modo de operação do pensamento mítico em
} 
mais concentrada à sua natureza e potencialidade de significação. Ao isolar-se do poema e ao dar-se a conhecer, a "ave" permite, assim, a intensificação da percepção original $^{120}$, pois encaminha um regresso à origem de sua própria enformação simbólica.

Se pensada sob o signo da Fênix, ser duplamente fabuloso, como designa Gaston Bachelard, que se inflama em seu próprio fogo e renasce de suas próprias cinzas, a "ave" de Eugénio de Andrade também se definiria como "uma imagem tornada verbo", suscitando uma multiplicidade de sentidos e fazendo renascer o canto do silêncio a cada novo gesto (BACHELARD, 1990 p. 73). Segundo o crítico, na poesia moderna, encontramos diversas "fềnix implícitas" como essa, que não queima como a ave do mito, mas que, rodeada de luz no poema, também se dissolve como o fogo, marcando um instante do universo: "A Fênix é um ser do universo. [...] É a mestra dos instantes mágicos da vida e da morte" (BACHELARD, 1990, p. 61). Contudo, Bachelard adverte que uma versão moderna da Fênix não deve ser lida apenas como um pastiche do mito, já que o poeta sempre reencontra, de modo novo, os poderes lendários: "Estamos numa época em que o poético suplanta a tradição mítica, em que a poesia não tem mais a necessidade da tela dos mitos para bordar as imagens de seus poemas". ${ }^{121}$

contraposição ao pensar discursivo, Ernst Cassirer escreveu: “[...] Aqui as coisas não são tomadas pelo que significam mediatamente, mas por sua aparência imediata, sendo apreendidas e corporificadas como pura atualidade. É fácil ver que esta espécie de corporificação deve gerar uma posição básica, em face da palavra, de seu teor e de sua força, inteiramente diversa da adotada em relação ao pensamento discursivo. Para este, a palavra é essencialmente um veículo a serviço da tarefa principal a que esta forma de pensamento se propõe, ou seja, o estabelecimento de uma relação entre o conteúdo intuitivo, singular e momentaneamente presente, e outros que lhe "correspondem" de um modo direto, ou de alguma outra maneira, ou que se conectam com ele segundo uma lei determinada de coordenação. O sentido do pensamento discursivo desabrocha na confecção e expressão de semelhantes relações. Assim concebido, surge como algo essencialmente ideal, como um "signo" ou símbolo, cujo conteúdo não é discernível verdadeiramente em um estar-aí (Dasein) substancial próprio, mas, antes, nas relações de pensamento que institui. Pois a palavra, como se fosse uma estrutura de outra ordem, de uma nova dimensão intelectual, interpõe-se, por assim dizer, entre os diferentes conteúdos perceptivos, tais como se impõem à consciência no seu imediato aqui e agora [...]". Linguagem e mito. São Paulo: Perspectiva, 2009, p. 74.

120 "Há um reino do espírito no qual a palavra não só conserva seu poder figurador original, como, dentro deste, o renova constantemente; nele, experimenta uma espécie de palingenesia permanente, de renascimento a um tempo sensorial e espiritual. Esta regeneração efetua-se quando ela se transforma em expressão artística. Aqui torna a partilhar da plenitude da vida, porém, se trata não mais da vida miticamente presa e sim esteticamente liberada" (CASSIRER, 2009, p. 115).

${ }^{121}$ Fragmentos de uma poética do fogo. São Paulo: Editora Brasiliense, 1990, p. 85. Bachelard cita LéviStrauss ao tratar da questão da apreensão do mito na poesia moderna: "Claude Lévi-Strauss, numa visão profunda, defende a tese de que um mito é o conjunto de suas variantes, que uma nova variante faz imediatamente corpo com o mito. Essa incorporação de uma variante singular à imagem central da Fênix é ainda mais surpreendente. A Fênix é uma soma de valores poéticos, jogo de múltiplas correspondências: fogo, bálsamo, canto, vida, nascimento, morte" (1990, p. 85). 
Clemens Lugowski ${ }^{122}$, no entanto, chama a atenção para o fato de que os aspectos formais no poema mantêm viva a memória do mito, ainda que a poesia e a literatura no período moderno já não tratem mais de assuntos míticos, como de deuses ou de forças sagradas:

[...] Enquanto a vitalidade original do mito desvaneceu, os remanescentes do pensamento mítico permanecem nas estruturas estéticas. O caráter meramente formal da presença mítica e sua discrepância em relação à vida largamente desmitificada são as razões para a rápida desintegração do análogo mítico na história moderna da narrativa. No entanto, limitada à esfera estética, a estrutura mítica determina os contornos básicos do mundo poético, de maneira análoga ao modo com que os "conteúdos" míticos determinavam a semântica das imagens no mundo antigo. Uma perspectiva que percebe o mundo em grande parte como uma entidade abrangente e coerente sobrevive anonimamente nas formas supraindividuais. Os escritores, as obras e os círculos de leitores estão unidos na aceitação mútua dos gestos formais que correspondem àquela imagem do mundo, criando, por conseguinte, um senso de propósito comum.

(LUGOWSKY, 1990, p. 13) $)^{123}$

A visão mítica, assente na ideia totalizante do mundo e dos seres, permanece nas formas estéticas e no modus operandi do pensar metafórico, simbólico ou imagético do fazer poético. ${ }^{124}$ A imagem instável da ave procura fazer sobressair a natureza

\footnotetext{
${ }^{122}$ Assim como Ernst Cassirer, André Jolles, e mais tarde Heinz Schlaffer e Clemens Lugoswki, buscou o entendimento das formas artísticas com base em seu relacionamento com as formas primárias do mito. Embora tenha tratado mais especificamente das formas narrativas, seu trabalho também lança luz na relação entre poesia e mito. Cf. Form, Individuality and the Novel. Trad. por John Dixon Halliday. Oklahoma: University Press, 1990.

${ }^{123}$ Tradução nossa. "[...] While the original vitality of myth has faded, the remnants of mythic thought have gone over into aesthetics structures. The merely formal character of the mythic presence and its discrepancy vis-à-vis a large de-mythologized life are the reasons for the rapid disintegration (Zerrüttung) of the mythic analogue in the modern history of narrative. However, limited to the aesthetic sphere the mythic structure manages to determine the basic contours of poetic world pictures in a similar way to how mythic 'content' used to determine the semantics of the archaic world picture. A perspective that perceives the world largely as an all-embracing, coherent entity exists anonymously in supraindividual formal areas. Writers, works of literature and the circle of readers are united in the mutual acceptance of the formal gestures that correspond to that world image, thereby creating a sense of common purpose" (LUGOWSKY, 1990, p. 13).

${ }^{124}$ Sobre o pensar metafórico: "Se a antiga retórica já reconhecia como um dos principais tipos de metáfora a substituição do gênero pela espécie e da parte pelo todo, ou vice-versa, agora se faz tanto mais visível até que ponto tal classe de metáfora decorre diretamente da essencialidade espiritual do mito. [...] Para o mito se trata de algo muito diferente e muito além de uma simples 'substituição'; que aquilo que, para a nossa reflexão subsequente, parece ser mera transferência, constitui, para o pensar mítico, na realidade, uma autêntica e imediata identidade" (CASSIRER, 2009, p. 111). Northrop Frye também distinguiu as relações de analogia e de identidade como principais elementos tanto do mito quanto da poesia, as quais aparecem nas figuras de linguagem mais comuns, como a símile e a metáfora. Fábulas de
} 
específica e artificial da poesia, que impõe ao leitor o ajuste imediato a convenções poéticas desligadas do pensamento lógico-cientificista dominante no período moderno. $\mathrm{O}$ fato de que o leitor geralmente adere prontamente e com naturalidade a essas convenções revela que a poesia exige que se adote uma dada atitude não muito distante daquela que envolvia a imaginação mítica e o senso de comunidade do homem antigo. A "ave" em movimento, portanto, desmancha e recompõe o corpo do poema, desdobrando as formas poéticas para que nelas se experimente aquilo que por nós hoje é apenas pressentido.

Conforme discorre Octavio Paz: "Nem todos os mitos são poemas, mas todo poema é mito" 125 , ou seja, todo poema é "recriação arquetípica do tempo arquetípico", invocando e convocando o tempo original: "O mito é uma realidade flutuante, sempre disposta a se encarnar e voltar a ser.” (PAZ, 1982, p. 76). Contudo, esteticamente alienada da mitologia e da religião, que no passado supostamente (segundo a perspectiva da reflexão moderna sobre o passado mítico) integravam-se mais imediatamente à arte, a poesia moderna encontra-se, pela primeira vez, "sob um céu descoberto": “[...] A oposição entre o espírito moderno e a poesia inicia como um acordo. Com a mesma decisão do pensamento filosófico, a poesia tenta fundar a palavra poética no próprio homem. O poeta não vê em suas imagens a revelação de um poder estranho" (PAZ, 1982, p. 285).

Desse modo, se, por um lado, as formas estéticas possuem ressonância mítica, por outro, desligadas no período moderno de uma dada imagem do mundo, elas emancipam-se em palavras de negação. O poema moderno é duplamente negativo, tanto na forma como na consciência da contingência da forma. É só por meio dessa necessária consciência que se pode ampliar o processo de criação (e também de recriação, que constitui toda leitura). Ainda segundo Paz, se a gesta da poesia ocidental, desde o romantismo alemão, foi a de suas rupturas e reconciliações com o movimento revolucionário (PAZ, 1982, p. 311), a poesia moderna caracteriza-se, consequentemente, pela tentativa de reconciliação entre poema e ato, "palavra viva e palavra vivida, criação da comunidade e comunidade criadora" (PAZ, 1982, p. 309). Depreende-se daí toda a sua tendência crítica e necessidade de investigar o processo de

identidade: estudos de mitologia poética. Trad. Sandra Vasconcelos. São Paulo: Nova Alexandria, 2000, p. 42.

${ }^{125}$ O arco e a lira. Rio de Janeiro: Nova Fronteira, 1982, p. 77. 
criação: "O poema é um espaço vazio mas carregado de iminência. Ainda não é a presença: é um conjunto de signos que procuram seu significado e não significam outra coisa além de ser procura" (PAZ, 1982, p. 322).

Perdendo-se a transcendência do significado, a poesia pôde abrir-se a contingentes. O poema moderno abre-se em direção ao infinito (Paz, 1982, p. 332). A negação da poesia é também exaltação do ato poético, celebração do homem e da possibilidade (o homem moderno passa a ser visto em termos de possibilidade):

Assim, esse poema que nega a possibilidade de dizer algo absoluto, consagração da impotência da palavra, é ao mesmo tempo o arquétipo do poema futuro e a afirmação plena da soberania da palavra. Não diz nada e é a linguagem em totalidade. Autor e leitor de si mesmo, negação do ato de escrever e escritura que renasce continuamente de sua própria anulação.

(PAZ, 1982, p. 334)

O ser, o mundo e as essências não são mais algo dado, mas algo que é feito. $\mathrm{O}$ poema torna-se, por conseguinte, o lugar simultaneamente esvaziado e pleno que possibilita ao homem a conquista de seu ser, a realização de suas potencialidades e a transcendência de sua condição. Portanto, se o pendor mítico de imagens como a da "ave" pode revelar num vislumbre a unidade primordial do ser, essa revelação é igualmente criação de nós mesmos. O poema é homem, tempo e espaço fabricando-se.

Nesse sentido, a realidade sensorial do "voo" permite vivenciar um novo modelo de temporalidade, em que tanto a figuração espacial quanto a temporal se distanciam da usual noção de linearidade, atualizando-se em uma nova esfera onde passado, presente e futuro se encontram, mesmo que para serem captados como eterna fluidez e movimento. Por isso, a "ave" revela-se tão paradoxal: de um lado aponta para a desintegração e perda da cena paradisíaca e de outro possibilita a abertura para uma nova vivência do espaço e do tempo, como que a alargar a presença reversível do instante. Desse modo, a "ave" desponta como elemento mediador entre as oposições apresentadas pelo poema em relação à vivência do tempo. ${ }^{126}$

\footnotetext{
${ }^{126}$ Os elementos estruturais do mito, tais como descritos por Lévi-Strauss, em "The structural study of myth" (Myth - critival concepts in literary and cultural studies. London/NY: Routledge, 2007, pp.161 à 180), guardam semelhanças estruturais com o signo da ave no poema acima, e também com a própria disposição rotatória dos demais signos que analisamos na poesia eugeniana: "[...] Myth, like the rest of language, is made up of constituent units. [...] The true constituent units of a myth are not the isolated relations but bundles of such relations and it is only as bundles that these relations can be put to use and combined so as to produce a meaning" (p. 165). ("O mito, como toda linguagem, é formado de unidades
} 
O trabalho contínuo de transubstanciação que a poesia eugeniana realiza da própria sensação de perda do instante - frequentemente agregada à dor da separação da mãe - revela-se em imagens fugidias e evanescentes como essa (bem como os "sonhos tresmalhados" do poema), ou como, por exemplo, as "pedras" lançadas ao horizonte em "Abril", poema imediatamente posterior a "Os amantes sem dinheiro", no qual novamente encontramos uma criança em meio às primeiras descobertas:

\begin{abstract}
Abril
Brinca a manhã feliz e descuidada, como só a manhã pode brincar, nas curvas longas desta estrada onde os ciganos passam a cantar.

Abril anda à solta nos pinhais coroado de rosas e de cio, e num salto brusco, sem deixar sinais, rasga o céu azul num assobio.

Surge uma criança de olhos vegetais, carregados de espanto e de alegria, e atira pedras às curvas mais distantes - onde a voz dos ciganos se perdia.
\end{abstract}

(ANDRADE, 1966, p. 66)

Embora o cenário seja de infância e de êxtase paradisíaco, em que a própria manhã de "Abril" brinca junto à criança, enleada aos elementos da paisagem "no cio", há o contraponto da fugacidade do tempo. A estrada impõe a movimentação do espaço e nela "ciganos" passam a cantar, cujas vozes já se perdem na "curva". "Ciganos", sem

constituintes. [...] As verdadeiras unidades constituintes de um mito não se traduzem pelas relações isoladas, mas pelos agrupamentos de tais relações, e é somente nesses agrupamentos que as relações podem ser postas em prática, ou combinadas para gerarem sentido". Tradução nossa). Ao analisar os constituintes do mito, Strauss verifica que as relações contraditórias entre eles são superadas, ou melhor, substituídas pela afirmação de novos elementos que imediatamente fazem com que essas relações se tornem idênticas ou se autocontradigam. Assim, o mito procura lidar com os termos conflitantes, de modo a buscar uma mediação, uma transição. $\mathrm{O}$ mito trabalha sobre o elemento da constante permuta entre os pares contraditórios: "[...] Mythical thought always works from the awareness of oppositions towards their progressive mediation. [...] Thus we may have mediations of the first order, of the second order, and so on, where each term gives birth to the next by a double process of opposition and correlation" (p. 175). (“O pensamento mítico sempre se estrutura na consciência das oposições a caminho de suas progressivas mediações. [...] Assim, podemos ter mediações de primeira ordem, de segunda ordem, e assim por diante, em que cada termo gera o próximo através de um processo duplo de oposição e correlação". Tradução nossa). Os elementos mediatores nos mitos sempre retêm, portanto, algo da dualidade anterior e um caráter nomeadamente ambíguo. Embora já libertos da rigidez da estrutura mítica, a "ave" e os demais signos analisados parecem reservar traços dessas "formas simples", já que também possuem feições conflitantes e organizam-se em um regime de constante permuta. 
morada permanente, são passageiros como as "aves" e, no poema, produzem música que se confunde com imagem, já que o menino lança pedras ao espaço como se pudesse, literalmente, enxergar o som subindo aos ares. Música e imagem são novamente distinguidas como unidades essenciais da poesia e, desintegradas aqui, operam, assim como a "ave" no poema anterior, um retorno à enformação básica da palavra poética, permitindo que o leitor tenha acesso à emoção pura, à intuição, a uma dada excitação espiritual ou percepção sensorial que estão na base de qualquer formação simbólica. ${ }^{127}$

Desse modo, o poema poderia sugerir a visão do menino-poeta diante da descoberta de sua vocação, que atira pedras à música-imagem, como se pudesse tocá-la, e vislumbra um horizonte em ascensão, desmanchando a plenitude de "abril à solta nos pinhais".

Dentre todas essas imagens fluidas e recorrentes, a "ave", sendo o elemento nuclear nesse livro, encaminha, assim como o "fruto" no volume anterior, a uma visão da concepção poética eugeniana. Se considerarmos a themata da arte poética tal como listada por Lubomir Dolezel ${ }^{128}$, a "ave" oferece uma reflexão bastante vasta sobre os domínios e alcances da linguagem poética, além de apontar para o problema da criatividade, já que ela frequentemente se associa à mãe, figura identificada, desde o prefácio, como principal motivação do poético nesse segundo livro da coletânea. ${ }^{129}$

No quarto poema do livro, "Canção para minha mãe", em que a figura materna é diretamente nomeada, encontramos novamente a imagem de um pássaro, porém ligado agora a uma cena de outono e esterilidade - ainda que a criança apareça juntando os cabelos destrançados da mãe, triste a cantar. Dos braços dessa mulher escorriam "frutos maduros de outono" e "águas mortas de abandono": "Era o tempo das gaivotas / mas o

\footnotetext{
${ }^{127}$ É como se pudéssemos apreender "o momento em que a linguagem quer ser escrita", segundo os ensinamentos de Gaston Bachelard: "Consigo entrever os germes da ontologia poética em cada imagem literária um pouco nova” (BACHELARD, 1990, p. 34).

${ }^{128}$ A título de retomada, transcrevemos novamente a themata fundamental da poética ocidental descrita por Dolezel: o conceito de literatura como estrutura; o problema da relação entre arte poética e mundo; o problema da criatividade poética e a reflexão sobre a linguagem (DOLEZEL, 1990, p. 21).

${ }^{129}$ Gostaríamos de acrescentar que, do total de vinte e três poemas em Os amantes sem dinheiro, quinze (ou $65 \%$ ) possuem títulos que remetem à questão da arte poética. Alguns deles refletem a situação da escrita propriamente dita, como "Improviso na madrugada"; outros afirmam uma espécie de programa, como "Conselho" ou "Improviso para uma fonte"; e outros ainda enumeram formas e temas poéticos, como "Canção breve", "Madrigal”, Canção para minha mãe", "Imagem", "Rumor", "Elegia", "Apenas um rumor", "Quase nada", "Poema à mãe", "Soneto", "Outro poema para o meu amor doente" e "Ode a Guillaume Apollinaire".
} 
mar tinha secado", e depois: "Gaivotas não as havia / e o mar tinha secado." (1966, p. 67). ${ }^{130}$

O ambiente de esterilidade e ceticismo também está presente em "Apenas um rumor", poema 20, em que a "palavra" é equiparada ao "rumor" de um bando de "gaivotas":

\section{Apenas um rumor}

... E no teu rosto aberto sobre o mar cada palavra era apenas o rumor de um bando de gaivotas a passar.

(ANDRADE, 1966, p. 88)

A expressão adverbial "apenas" denota a fragilidade e talvez a impermanência do canto e do instante pleno. Esse poemeto assemelha-se aos versos do poema 19, intitulado "Outro poema para o meu amor doente": "Outono - pássaro de melancolia/ num céu sem cor que não promete nada" (1966, p. 87), em que o "céu", como o "mar" do poema acima, afigura-se como espaço de abertura, mas que, desta vez, não encontra o fluir expansivo da "ave".

Em "Canção breve", encontramos uma referência indireta aos "gestos" do poema "Os amantes sem dinheiro", agora inseridos no contexto de um amor triste e antigo, que poderia muito bem incluir a relação materna:

Tudo me prende à terra onde me dei $[\ldots]$

Tudo me prende do mesmo triste amor que há em saber que a vida pouco dura, e nela ponho a esperança ou o calor de uns dedos com restos de ternura.

Dizem que há outros céus e outras luas e outros olhos densos de alegria, mas eu sou destas casas, destas ruas, deste amor a escorrer melancolia.

(ANDRADE, 1966, p. 71)

\footnotetext{
${ }^{130} \mathrm{O}$ primeiro par de versos que transcrevemos acima encontra-se, no poema, entre parênteses, assim como a quinta estrofe: "(Uma criança juntava/ o cabelo destrançado"). Os dois pares parecem revelar cenas mais esperançosas dentro do quadro de esterilidade e tristeza em que se situa a figura da mãe, o que poderia sugerir a voz ou a perspectiva do menino.
} 
"Amor a escorrer melancolia" lembra a imagem da mulher triste de "Canção para minha mãe", de cujos cabelos, braços e pernas também escorriam, como vimos, elementos melancólicos, como "frutos de outono" e "águas mortas de abandono". Os "dedos com restos de ternura" e o "triste amor que há em saber que a vida pouco dura" trazem à cena a imagem do pássaro a nascer dos dedos dos amantes e a sensação de passagem e transformação que o poema "Os amantes sem dinheiro" suscita, de modo que, tanto naquele quanto neste poema, a figura materna permanece como elemento fulcral, mesmo quando não nomeada.

Do mesmo modo, "Elegia", poema 13, parece se dirigir à mãe e às lembranças desse amor doído, já que estabelece diálogo direto com "Poema à mãe", 15 do livro:

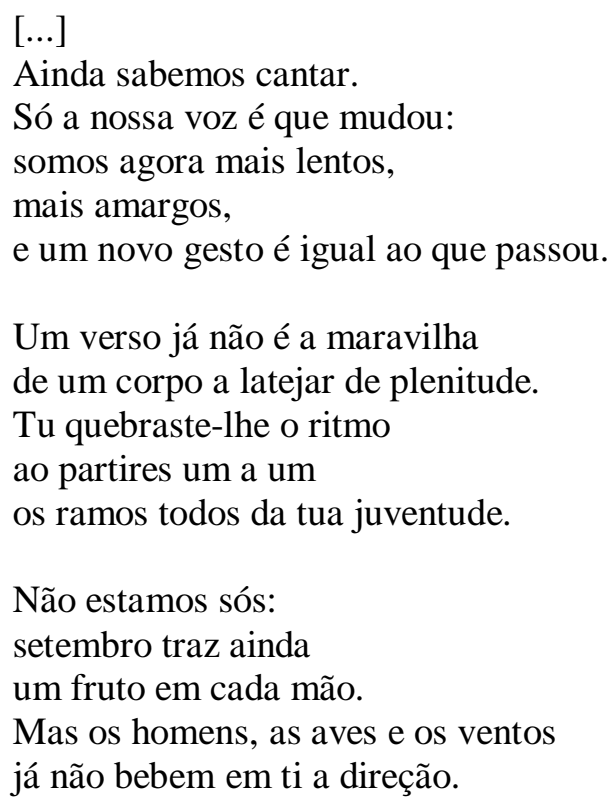

(ANDRADE, 1966, p. 77)

Novamente há alusões aos "gestos", porém aqui acompanhados de ceticismo e melancolia. As "aves" reaparecem, assim como os "ventos" e os "frutos" do poema de abertura do livro ("Conselho"), entretanto, já deslocados do antigo e prometido furor poético, apontando agora para os desgastes dos mecanismos outrora associados à plenitude na infância e à relação materna: "Os homens, as aves e os ventos/ já não bebem em ti a direção".

O primeiro verso do trecho selecionado acima também poderia sugerir relações com a mãe do poema, frequentemente associada à "primeira música" que tanto motiva a gênese de sua poesia. Contudo, as condições favoráveis à poesia agora são descritas em 
termos de cansaço e esgotamento. Há uma mudança de direção dos mecanismos de inspiração. A "mãe" não provê mais o "fruto", embora ele ainda esteja presente em "cada mão". Há uma certa "quebra de ritmo" e quebra dos "ramos da juventude" que oferecem agora ao eu lírico uma reflexão dolorida sobre os efeitos da velhice, do esquecimento, da distância natural entre mãe e filho.

Em "Poema à mãe", 15 do livro, as queixas sobre a relação viciada entre mãe e filho são explícitas: o sujeito lamenta o esquecimento por parte de ambos, em que talvez haja se perdido o conhecimento do "verdadeiro ser" que os dois experimentaram intensamente durante o período pleno de descobertas e encantos. Esse conhecimento profundo e rico já não cabe mais na imagem rígida e intacta de um "retrato":

\section{Poema à mãe}

No mais fundo de ti, eu sei que te traí, mãe!

Tudo porque já não sou o retrato adormecido no fundo dos teus olhos!

Tudo porque tu ignoras que há leitos onde o frio não se demora e noite rumorosas de águas matinais!

Por isso, às vezes as palavras que te digo são duras, mãe,

e o nosso amor é infeliz.

Tudo porque perdi as rosas brancas que apertava junto ao coração no retrato da moldura!

Se soubesses como ainda amo as rosas, talvez não enchesses as horas de pesadelos ...

Mas tu esqueceste muita coisa!

Esqueceste que as minhas pernas cresceram, que todo meu corpo cresceu, e até o meu coração ficou enorme, mãe!

Olha, queres ouvir-me?: às vezes ainda sou o retrato que adormeceu nos teus olhos;

ainda aperto contra o coração rosas tão brancas 
como as que tens na moldura;

ainda oiço a tua voz:

Era uma vez uma princesa

no meio de um laranjal...

Mas - tu sabes! - a noite é enorme

e todo meu corpo cresceu...

Eu saí da moldura,

dei às aves os meus olhos a beber.

Não me esqueci de nada, mãe.

Guardo a tua voz dentro de mim.

E deixo-te as rosas...

Boa noite. Eu vou com as aves!

(ANDRADE, 1966, p. 81)

O ciclo está gasto, o eu lírico lamenta a mudança, ainda que, no fundo, continue o mesmo menino que "ama as rosas brancas", signo de pureza que remete à inocência da infância ${ }^{131}$. Ele ainda ouve a "voz", o cantar da mãe, mas o presente é distinto e requer novos gestos. O sujeito então se despede e, em um ato de transfiguração de signos do passado, ou de rasura do "retrato", permuta "as rosas brancas" por "aves". Eis dois signos que se associam tanto à relação materna, como vimos, quanto ao cantar poético ${ }^{132}$, sempre vinculado à questão da memória neste livro. $^{133}$

${ }^{131}$ Além das pétalas macias, a "rosa" possui, por outro lado, espinhos: simbologia que aponta para a ambiguidade do amor materno. As rosas brancas também evocam uma imagem fúnebre, que simbolicamente poderia relacionar-se com o problema do retrato, já que este só pode guardar uma imagem "morta" do passado, intacta e impossível de ser atualizada. Para salvar a sua própria poesia, fadada ao ciclo vicioso, ao ramerrão à aridez, o poeta decide romper com o passado morto despedindo-se da mãe, figura que constantemente tenta emoldurar o filho em suas imagens fixas do passado. O poema põe em movimento (atualizando, assim) a significação das "rosas brancas", que agora já perdem a carga de inocência e pureza, outrora atribuídas pela mãe ao menino e também à vivência do poético.

${ }^{132}$ No sétimo poema do livro, intitulado "Retrato", o sujeito observa uma fotografia e vislumbra uma "luz abrindo", "uma madrugada" que nasce do rosto retratado, indo de "rosa em rosa", "transparente e molhada". A intensa luminosidade, aliada à "melodia / distante mas segura", poderia sugerir o irromper da palavra poética, associada aqui às "rosas brancas" (ANDRADE, 1966, p. 70). Citamos também um verso de Ostinato rigore, último livro da coletânea, em que a relação entre a rosa branca e a palavra poética é mais uma vez estabelecida: "Sê tu a palavra, / branca rosa brava" (ANDRADE, 1966, p. 210).

${ }^{133}$ Embora pertencente à fase posterior da obra de Eugénio de Andrade, transcrevemos aqui trechos de um poema bastante significativo, do livro Branco no branco (1984), em que se expressa mais uma vez a oposição entre "rosas brancas" e "aves", sobretudo em relação ao problema materno: "[...] Suportas mal o ar, dividido / entre a fidelidade que deves / à terra da tua mãe e ao quase branco / azul onde a ave se perde". Poesia. $2^{\mathrm{a}}$ ed. revista e acrescentada. Posfácio de Arnaldo Saraiva. Porto: Fundação Eugénio de Andrade, 2005, p. 353. À respeito da tensão entre a questão materna e a linguagem, Carlos Mendes de Sousa realizou um extenso trabalho, já citado no capítulo anterior, em que se debruça sobre a metáfora materna na poesia eugeniana. Acrescentamos aqui um trecho significativo do primeiro capítulo, "Metáfora, o lugar da mãe", que ilumina o trajeto interpretativo que ora traçamos sobre a relação entre a 
A memória é referida por meio de um paradoxo: de um lado é representada por retratos, recordações rígidas e imóveis que mal interferem no presente; e de outro por certas imagens "móveis" do passado, como as "aves" a se desprenderem dos gestos, capazes de evocar certa lembrança do poético, da vivência da totalidade dos elementos, da movimentação da palavra, cuja natureza metamórfica atualiza a experiência e supera a corrosão do tempo, apreendendo a multiplicidade da vida. Assim, por meio de um signo concreto como "aves", a poesia eugeniana sugere o abstrato material da memória em suspensão, capaz de ser mobilizado pelo fazer poético. Nesse espaço silencioso e confuso "voam" imagens e sons primitivos que segredam os primeiros milagres. No impreciso ponto de encontro entre o presente e o passado acham-se as aves suspensas de outrora, vigiando a promessa de um dia se realizarem.

Ao despedir-se da mãe e dizer que segue "com as aves", o eu lírico toma a determinação de sair da "moldura" do retrato para transfigurar-se em canto. Afirma a sua vocação de poeta e opta pelo caminho incerto e instável das "aves", porém de imensurável libertação.

Por conseguinte, na imagem que a mãe tem do filho já não cabe o erotismo de "leitos onde o frio não se demora", tanto quanto a perda da juventude da mãe se tornou insuportável ao filho (como o verso "tu quebraste [...] os ramos todos da tua juventude" do poema anterior também sugere). Contudo, tal esquecimento (tanto da mãe que esquece que o filho cresceu quanto do filho que também esquece que ela envelheceu) é superado pelo canto: "Queres ouvir-me? / Às vezes ainda sou o retrato [...] / ainda aperto contra o coração rosas tão brancas [...] / ainda oiço a tua voz. / Não me esqueci de nada mãe".

O eu lírico simbolicamente mata a mãe, deixando-lhe as "rosas brancas", como em um ritual fúnebre, mas somente para poder rememorar e recriar tudo de novo no espaço do poema. Na permuta das "rosas brancas" por "aves", o canto atualiza a rica experiência do passado, mobilizando a memória, que oferece resistência à implacabilidade do tempo quando vivida de maneira a atuar sobre o presente. Assim, o canto pretende reconfigurar o passado e atribuir-lhe novos sentidos pertencentes à vida adulta, de modo a manter-lhe a potência criadora.

\footnotetext{
"rosa branca" e a "ave": "Entenda-se, aqui, na questão do materno, a essencial questão da língua. Onde infinitamente ocorre o interdito. No rompê-lo está a própria origem da escrita, o próprio nascimento do escritor - 'o verdadeiro incesto é incesto com a língua materna. É preciso que a língua, como a mãe, permaneça interdita" (SOUSA, 1992, p. 11).
} 
Em Eugénio de Andrade, as representações da memória confundem-se com as representações da palavra poética, o que evidencia a conexão profunda entre o processo de rememoração e o fazer poético. A palavra depende da plenitude vivida pelo sujeito, que, motivado pelo amor e pela entrega, colhe os registros de um presente absoluto. A memória preserva os instantes ontológicos - pois é a memória que constitui o ser - , e o germe da palavra nasce para o poeta: levanta voo como aves, penetra os espaços, assim como a "luz", "o rumor", "o canto dos ciganos" sumindo ao longe. Das imagens revisitadas pelo sujeito poético depreendem-se elementos fugazes, que partem do momento registrado para penetrar em uma espécie de hiato que a memória produz na relação entre o passado e o presente.

É a consciência do próprio ato poético que estabelece a união ontológica entre os tempos de outrora e os tempos recentes, para que o sujeito instaure o sentido de sua própria existência. A confecção da poesia é feita a partir dessas correspondências estabelecidas pelo sujeito poético, que, ao atuar sobre as memórias, resgata esses elementos transitórios como elos entre o passado e o presente, e reconstitui, em seu cantar, a unidade perdida, experimentada na infância.

Desse modo, a palavra poética marca essa ausência, ao mesmo tempo que refaz o passado paradisíaco: preenche e produz ausência, sempre. Eugénio de Andrade firma a sua vocação de poeta ao reconstituir-se como sujeito liberto da mãe e ao tomar consciência do próprio ato do fazer poético, o qual demanda mobilização da memória e atuação sobre ela. É para esse novo espaço de consciência que segue o poeta em perpétua busca de sua própria sentença: "Boa noite. Eu vou com as aves!”.

Mas se as aves sugerem esse desprendimento, nos poemas seguintes, como no 17 e no 23 , encontramos certa hesitação. No primeiro, intitulado "Rumor", temos:

\section{Rumor}

Acorda-me um rumor de ave.

Talvez seja a tarde a querer voar.

A levantar do chão qualquer coisa que vive, e é como um perdão que não tive.

Talvez nada. 
Ou só um olhar

que na tarde fechada

é ave.

Mas não pode voar.

(ANDRADE, 1966, p. 85)

A "ave" pretende afirmar-se como um "perdão que não tive", podendo se referir novamente ao ressentimento materno. Mas não alcança a libertação prometida de "Boa noite. Eu vou com as aves".

No último poema do livro, "Adeus", encontramos nova despedida, porém enleada à desesperança: “[...] O passado é inútil como um trapo. / E já te disse: as palavras estão gastas. / Adeus" (ANDRADE, 1966, p. 91). Mais uma vez é reforçada a vontade de manter o curso de sua poesia em movimento, como se assim ela pudesse adquirir o abandono das aves em metamorfose: valendo das lembranças, mas em constante trabalho de transmutação.

O livro expõe, portanto, ciclos em que o sujeito investiga o passado, sobretudo nos pontos em que ele configura uma identidade poética. Nesse sentido, a figura materna é peça principal, que aparece desde o prefácio, como aquela que inspirou no filho o dom das palavras e a necessidade de desfrutar o mundo. Com a passagem do tempo, no entanto, o sujeito lamenta o desgaste dessa relação, sobretudo como influência sobre o cantar poético. Certos poemas irão, assim, demonstrar esforços para transfigurar a ausência e a angústia, principalmente com o propósito de renovar os processos constituintes da poesia e mantê-los atuantes, acima da própria corrosão do tempo. Com isso, aspira-se a uma unidade mítica que, se antes era contemplada no arquétipo da mãe, topos da união com o cosmos e da comunhão primordial com o mundo, com o desgaste da relação, passa a ser realizada pela atividade poética. A mãe torna-se, desse modo, um empecilho para o retorno da união entre sujeito e mundo, e para o fluir da palavra poética. Ao manter o "retrato" antigo do filho, impede toda transformação. A “ave" possibilita, portanto, o nascimento de uma nova identidade do poeta, que vence a culpa através da vontade afirmadora da poesia, procurando o retorno à unidade perdida. Ao mesmo tempo, porém, há o reconhecimento crítico e doloroso de que toda unidade só pode ser provisória. 


\subsection{O "navio" cortante} Um pássaro e um navio são a mesma coisa
quando te procuro de rosto cravado na luz.

(Eugénio de Andrade, 1966, p. 114)

Antes que a morte se aproxime, procuro-te. Nas ruas, nos barcos, na cama. (Eugénio de Andrade, 1966, p. 114)

O compromisso do poeta é com o amor e o acto um acto livre no tempo-único. (A. M. Lisboa, 1950) $)^{134}$

As palavras interditas (1950-1951) localizam-se, temporalmente, em um período conturbado da história portuguesa, em que o regime ditatorial, instaurado desde $1926^{135}$, sofria redefinições após o desfecho da Segunda Guerra Mundial (1939-1945). Na contramão das ideias democráticas e anti-imperialistas difundidas no Ocidente a partir da vitória dos Aliados, percebia-se, em Portugal, a instalação de uma autocracia cada vez mais rígida, com o propósito de manter as políticas totalitárias e a "integridade africana", conforme explica a historiadora portuguesa Adelaide Ginga Tchen, que escreveu sobre o contexto histórico, político e artístico desse período no país. A autora demonstra que a "democracia orgânica" de António Oliveira Salazar, resultante das acomodações do pós-guerra, já entrava em crise nos anos 1950:

A oposição ao salazarismo crescia e o armistício trouxe uma aurora de expectativa, um cheiro de liberdade, acreditando muitos que a maré de vitória dos aliados, que deitara por terra os fascismos europeus, se estenderia a Portugal. A possibilidade de mudança seria traída pelo próprio desenvolvimento da conjuntura política euro-atlântica, cujos interesses permitirão a Salazar manter-se no poder e prolongar o regime durante praticamente mais três décadas. ${ }^{136}$

Sem entrarem na discussão política diretamente, quer dizer, sem nomearem nenhum partido ou grupo de oposição, As palavras interditas expressam de modo

\footnotetext{
134 "Erro Próprio". Poesia de António Maria Lisboa. Lisboa: Assírio \&Alvim, 1980, p. 81

${ }^{135}$ O regime ditatorial português é fundado com o golpe militar de 28 de maio de 1926. António Oliveira Salazar, um professor de Economia, é nomeado ministro das Finanças em 1928. Com o êxito da sua "Reforma Orçamental", Salazar adquire popularidade e em 1932 assume a chefia do governo, fundando o "Estado Novo", respaldado na aprovação de uma nova Constituição, que havia sido criada no modelo do Estado corporativo de Mussolini. O regime se estende até a morte de Salazar em 1970. Cf. The Making of Portuguese Democracy. Kenneth Maxwell. Cambridge: University Press, 1995, pp. 7 a 29; e "O Estado Novo: Salazarismo, Fascismo e Europa". Luís Reis Torgal. História de Portugal. Org. José Tengarrinha. São Paulo: Editora da Unesp, 2001, pp. 391 a 415.

${ }^{136}$ A aventura surrealista: o movimento em Portugal do casulo à transfiguração. Lisboa: Edições Colibri, 2001, p. 54.
} 
contundente a atmosfera de pessimismo e desilusão que pairava em Portugal no início da década de 1950, principalmente após a tentativa frustrada de eleições ${ }^{137}$ e a consequente manutenção do governo autoritário e conservador de Salazar. O título do livro parece aludir, de modo mais direto, ao problema da censura ${ }^{138}$, que desde os anos 1930 se tornara mais acirrada, principalmente no campo literário, como explica Tchen.

Assim, em referência a tudo aquilo que não pode ser dito no país no momento, sob um regime violento e autoritário, a escrita eugeniana se escreve, neste livro, pela negativa e pela ausência. Aponta para um cenário devastado, fragmentado, despido de humanidade. Sem levantar bandeiras políticas, sua poesia demonstra a necessidade da ação por meio da expressão do amor, tornado cada vez mais improvável no contexto totalitário, em que os afetos são controlados, e as relações sociais rigorosamente

${ }^{137}$ Conforme explica Ana Sofia Ferreira: “O Estado Novo, apesar de ser uma ditadura, consagrou, na Constituição, a realização de eleições presidenciais, legislativas e para as Juntas de Freguesia, uma vez que só o voto popular podia fornecer a legitimação interna e externa de que necessitava. Todavia, os resultados eleitorais sempre foram controlados de modo a garantir a vitória do candidato ou da lista da União Nacional e todas as eleições foram fraudulentas. As eleições presidenciais de 1949 e 1958 foram dois desses momentos importantes para Portugal, em que o povo teria podido votar e decidir o futuro do país, mas em que a opressão, a censura, a violência e a fraude marcaram a campanha eleitoral e determinaram a votação, garantindo a vitória dos candidatos da Situação e a derrota dos da Oposição, apesar destes terem, inequivocamente, o apoio da maioria da população". Em "As eleições no Estado Novo: as eleições presidenciais de 1949 e 1958". Revista da Faculdade de Letras -HISTÓRIA, Porto, III Série. Vol. 7, 2006, pp. 197 à 212. http://ler.letras.up.pt/uploads/ficheiros/3412.pdf. Embora as sessões de propaganda tenham sido autorizadas, Norton de Matos, candidato da oposição, viu-se obrigado a desistir da candidatura nas vésperas da eleição, após uma onda de prisões de oposicionistas e também de operários, segundo também informa Daniel Bastos: "Para tal em muito contribuiu a mordaça salazarista e as medidas repressivas e violentas da censura e da PIDE [...]. Deste modo, estavam abertas as portas da vitória ao marechal Carmona, que dentro deste clima obliterado foi empossado para novo mandato, que durou até 1951, altura em que veio a falecer." Desde 1926 o general Óscar Carmona era sucessivamente reeleito para o cargo de presidente. "Para uma história das eleições presidenciais de 1949 e 1958 na Vila de Fafe". http://www.museu-emigrantes.org/ARTIGO-EleiçõesPresidenciaisnaViladeFafe(1949-58).pdf (acesso 15/08/2012, 15:53) p. 9.

${ }^{138}$ Tchen traça um panorama da censura durante a ditadura e identifica o momento em que ela se tornou mais rígida, ainda na década de 1930: “Já quando da Guerra Civil em Espanha, a política externa adoptada por Salazar tinha desencadeado reações de protesto por parte de vários intelectuais que se manifestaram a favor dos republicanos contra a violência franquista e o apoio a esta por parte de Salazar, o que originou em termos internos um apertar da censura e da coacção policial, particularmente no campo literário. Com a Segunda Guerra Mundial, a tentativa de impedir em Portugal a entrada de informação considerada subversiva que pudesse pôr em causa a estabilidade do regime e a verdade estabelecida tem uma forte repercussão nas liberdades cada vez mais restringidas pela ditadura. Assim, nota Carlos Reis: 'o que foi a actividade mutiladora e repressiva da censura sabem-no bem escritores, artistas e cineastas, jornalistas e ensaístas e todos os que, por desenvolverem uma actividade intelectual, tiveram de sujeitarse a procedimentos selectivos de ordem ideológica e política, que não de natureza estética'. Se até o Verão de 1940 Portugal se resguardara fechado em si próprio, mas já assente em terreno minado, a partir de então, a redoma não resistirá aos estrondos, e os sintomas de crise, de progressiva desagregação econômica e política da base social de apoio construída pelo regime nos anos 30, agudizam-se a partir de 1943, com a vaga de agitação social e política e o fragoroso impacte da queda de Mussolini, num ambiente dominado pela expectativa da inelutável derrota do Eixo. Os novos ventos de guerra sopravam mais fortes, e as notícias que traziam uma realidade bem diferente da propagandeada pelo regime não passavam desapercebidos aos espíritos atentos e pensadores, que se avivavam perante os problemas". (TCHEN, 2001, p. 53) 
dirigidas $^{139}$. Portanto, ainda que pelo avesso, pelo silêncio e pelos caminhos instáveis do não dito, a poesia eugeniana se empenha em dizer um amor proibido. ${ }^{140}$

Na ocasião da escrita e da publicação de As palavras interditas, o cenário literário agitava-se também por conta da "revolta surrealista", que tendo começado tardiamente em Portugal, por volta de 1947, encontra seu apogeu na virada para a década de 1950:

Se a transição da década de 1940 para 50 foi palco de acesas reflexões e polémicas sobre o presente e o futuro do homem e da arte em Portugal, o surrealismo ocupou aí lugar de destaque, responsável que foi na abertura de portas à criatividade artística e literária, com soluções de vanguarda, muito no esteio da publicação órphica de 1915: destruiu, subverteu e transgrediu... criando.

(TCHEN, 2001, p. 144)

\begin{abstract}
139 "A acção propagandística focada na doutrinação sistemática e tentacular sobre a sociedade civil com o objetivo de tornar o Estado em essência totalizante das relações sociais teve um aparente sucesso imediato, contudo, a penetração empreendida no campo dos artistas e pensadores revelar-se-ia insuficiente". (TCHEN, 2001, p. 49)

${ }^{140}$ Embora Eugénio de Andrade tenha se mantido discreto em relação às suas opções sexuais, num empenho contínuo para separar vida e obra, e sendo muitas vezes criticado por isso, há momentos em As palavras interditas em que o eu lírico parece se dirigir, amorosamente, a um interlocutor masculino, ainda que tal leitura, por demasiado indireta, possa ser contestada. A sensação de que o sujeito poético está a falar de um segredo se confirma, principalmente, no poema "Rosto afogado", antepenúltimo do livro, conforme veremos adiante. Esse problema central de um segredo ou amor proibido parece estar associado às "palavras interditas" do título, já que, como se sabe: "No Estado Novo podia-se ser homossexual, mas não se podia dizer", conforme o relato do jornalista São José de Almeida: "Como era ser homossexual no Estado Novo? Como era viver no reino do não dito e do semipermitido? As respostas encontradas pela Pública - com a ajuda de estudiosos e de homossexuais que viveram sob estes anos de chumbo, alguns dos quais ainda hoje aceitam apenas falar sob anonimato - revelam um quadro repressivo feroz para a generalidade dos homossexuais apanhados pelas rusgas da polícia e uma permissividade calada, que ignora, ou finge que não existe, a prática por uma elite que, pelo seu estatuto social, está acima da moral e sobretudo da lei. [...] 'A homossexualidade era o segredo que toda a gente sabia. E, como toda a gente sabia, ninguém dizia', afirma António Fernando Cascais, professor universitário e um dos mais antigos activistas da defesa dos direitos dos homossexuais em Portugal". Jornal Público, 28 de maio de 2012, http://www.publico.pt/Sociedade/o-estado-novo-dizia-que-nao-havia-homossexuais-mas-perseguiaos-

1392257. Outra evidência importante, encontramos no texto "Sem abrigo para tanto amor", em que Eugénio de Andrade narra sua relação com a poesia ainda na infância e na adolescência. O poeta deixa claro a associação que encontrou, desde cedo, entre identidade poética e libertação sexual, a despeito de todo silêncio e tabu: "Com Ciúme de António Botto voltei a sentir a terra faltar-me debaixo dos pés. Pedi explicações: que significava aquilo de um homem escrever poemas de amor para outro homem? Estavam todos a jantar: pai, mãe, filho e irmã. Olharam uns para os outros, ninguém disse nada. No fim da refeição, o engenheiro, já só comigo, disse-me que não havia nada a explicar, desde que o mundo era mundo, sempre houvera homens que amaram outros homens, e alguns tinham necessidade de o afirmar". Poesia e prosa. Vol. II. Lisboa: Limiar, 1990, p. 280. No entanto, tal precariedade do amor e da expressão humana no contexto do regime totalitário português, tal como denunciada por Eugénio de Andrade em As palavras interditas, pode ser lida em um âmbito mais universal, ou seja, a ausência ou o controlo dos afetos é algo que atingia a todos de maneira estrutural, e não só os homossexuais. Como é sabido, a censura portuguesa proibia manifestações de caráter "subversivo", incluindo não só escritos que fizessem alusões críticas ao regime ou à segurança do Estado, ou que elogiassem a revolução e as ideias comunistas, mas também aqueles que tivessem conteúdo erótico e pornográfico. Proibia-se qualquer demonstração de sexualidade; qualquer "ousadia" que expressasse os desejos, o erotismo, o corpo.
\end{abstract}


Embora não tenha participado do movimento, Eugénio de Andrade, como também os poetas de sua geração, foi fortemente influenciado pelas criações surrealistas $^{141}$, e podemos apontar nesse terceiro livro da coletânea certas consonâncias com a concepção poética surrealista, sobretudo na intersecção entre ética e estética, na vontade de ação política, no compromisso com o amor e com a libertação ${ }^{142}$ semelhança que se dá, antes de tudo, na atitude perante a realidade, e não propriamente em termos estilísticos, já que a linguagem de As palavras interditas é predominantemente discursiva e descritiva, afastando-se, de maneira ainda mais intensa do que nos demais livros da coletânea, da proposta surrealista de dar vazão aos desejos inconscientes por meio do entrechoque de imagens, em busca de uma linguagem que possibilitasse maior experimentação e abertura.

Mais próximos em data do segundo movimento surrealista português ${ }^{143}$, centrado na figura de Mário Cesariny ${ }^{144}$, que, em oposição "moral e teórica” ao Grupo Surrealista de Lisboa, funda "Os Surrealistas" em 1949, As palavras interditas captam e exprimem a mesma atmosfera de desilusão e desesperança que pairava em Portugal, tornada pública, inúmeras vezes, na voz e nos pedidos de urgência dos membros desse

\footnotetext{
${ }^{141}$ Eugénio de Andrade costumava citar Paul Éluard entre suas influências mais marcantes, como lemos no trecho: "Os grandes encontros são sempre encontros de juventude: Pessanha, Pessoa, Rimbaud, Lorca, Rilke e Éluard. [...] Foram estes, e não outros, por maiores que sejam, os poetas que encontrei na hora em que mais os necessitava". Entrevista "Da palavra ao silêncio". Eugénio de Andrade poesia e prosa (19401979). Vila da Maia: Imprensa Nacional, 1980, p. 307.

${ }_{142}$ A concepção de "ação" poética diferenciava-se da posição mais corrente tal como defendida pelos escritores neorrealistas, conforme explica Fernando J.B. Martinho, em Tendências dominantes da poesia portuguesa da década de 50. Lisboa: Edições Colibri, 1996, p. 65: "A poesia não é, pois, segundo Pedro Oom, uma 'técnica'; apresenta-se-lhe, antes, como um 'meio de conhecimento e acção' [...]. Dos 'frutos' do 'meio de conhecimento e acção' que a poesia é, não interessa se 'bons', se 'maus', 'só o poeta os aproveita'. A acção transformadora da poesia defendida pelo realismo social, por exemplo, é assim posta em questão. Ao mesmo tempo, porém, Pedro Oom encara a poesia como 'acção'. Em que sentido o faz? No sentido de uma acção que diz respeito apenas àqueles que possam sentir-lhes os efeitos? As palavras de Pedro Oom não parecem autorizar outra interpretação: só o poeta aproveita dos frutos do conhecimento poético, da acção poética, mais ninguém. E a convicção de que as consequências do acto poético se situam num plano estritamente individual leva-o a proclamar 'a inutilidade dos esforços para ligar o poeta a qualquer filosofia, política ou teologia'. [...] É em nome da radical singularidade do poeta que Pedro Oom sustenta tal posição. [...] Na poética de Pedro Oom, a rebeldia do poeta está para além da sua vontade, é como que parte da sua natureza, existe apesar dele: 'o poeta é rebelde sem premeditação, demolidor de tudo e de si próprio". Em As palavras interditas encontramos também essa valorização da solidão e da liberdade individual, conforme veremos adiante.

${ }^{143}$ A primeira geração surrealista abrange, segundo a caracterização histórico-literária elaborada pelos próprios artistas surrealistas e assumida pela crítica, em dois "movimentos", formados pelo "Grupo de Lisboa" e os "Os Surrealistas". Houve, a partir de 1955, uma segunda geração surrealista a qual pertenciam artistas e escritores frequentadores do Café Gelo em Lisboa.

${ }^{144}$ A primeira publicação de Mário Cesariny, em 1950, próximo, portanto, da data de publicação de As palavras interditas, foi subsidiada por Eugénio de Andrade, o que demonstra a proximidade e a afinidade entre os dois poetas. Cf. A intervenção surrealista. Mário Cesariny. Lisboa: Assírio \& Alvim, 1997.
} 
"grupo dissidente" 145 . Notam-se, entre as diversas declarações, leituras públicas e manifestos, apelos paralelos ao que encontramos, obsessivamente, em As palavras interditas, principalmente na procura da sutil "relação de liberdade entre o indivíduo e o coletivo":

Há verdadeiramente em todos estes esforços isolados um ponto único: o esforço vital para aperfeiçoar a poesia que tende a transformar a sociedade fechada em sociedade aberta. [...] O conceito, se há algum válido, de Poesia, e não Liberdade tal como nos é definida pelos racionalistas como possibilidade de Escolha através da Razão, mas como explosão acontecida no mais profundo do Ser. ${ }^{146}$

Em reação aos inúmeros reveses políticos e históricos, a poesia dos anos 1950 pretendia se erguer em defesa das liberdades individuais, dos afetos, do amor, da imaginação, do desejo: "Nós reduziremos a arte à sua expressão mais simples, que é o amor - evidência surrealista" ${ }^{147}$. Encontramos apelo semelhante em As palavras interditas: "A cidade onde te amei foi decepada / e não posso abolir as sentinelas do medo. / Mas também não posso deixar de te querer / com beijos e relâmpagos [...]" (ANDRADE, 1966, p. 111).

E, principalmente a partir de 1951, ano em que "Os Surrealistas" já se dispersavam, percebe-se o tom ainda maior de pessimismo e descrença nas declarações de alguns escritores e intelectuais da época:

Ninguém nesse ambiente chega a mais do que agir nas suspeitas das suas próprias energias, sem saber como e onde o medo se alastrou como trincheira e onde se domiciliou, muitas vezes até dignamente, mas tomado pelo vírus da frustração. O surrealismo foi aliás incompetente para usar de seu instrumento de ironia e transgressão da burguesia contra o status montado pelo atraso do país e a mediocridade das instituições sociais, com a apatia da população.

\footnotetext{
${ }^{145}$ Citamos como exemplo a frase do manifesto inaugural Erro próprio, elaborado em 1949 e, segundo Tchen,tornado um dos mais importantes documentos teóricos do surrealismo português: "Uma mudança de rumo em Todos e em tudo não pode deixar de começar em nós individualmente. 'Até que ponto pode chegar um homem desesperado quando o ar é um vómito e nós seres abjectos?'” (LISBOA, 1980, p. 81)

${ }^{146}$ Afixação Proibida - um cadavre-exquis composto por António Maria Lisboa e Mário Cesariny e apresentado na primeira comunicação do grupo, em 6 de Maio de 1949 (TCHEN, 2001, p. 113). Tal proposta de ação pretendia se afastar, contudo, da interpretação neorrealista da realidade, como declarava outro documento produzido pelo grupo: "Qualquer espécie de realismo socialista com todo o seu cortejo de estéticas, literaturas e políticas de partido, é tão prejudicial à liberdade do Homem como uma ditadura fascista, apenas conseguindo pôr no lugar de Deus um outro Deus igualmente absurdo", em "Comunicado pelos surrealistas". M.H. Leiria, A. do Cruzeiro Seixas; e João Artur da Silva, enviado a Taylor em 24/4/50, citado por Tchen (2001, p. 126).

147 "Subscrito por M. H. Leiria, M. Cesariny de Vasconcelos, C. Eurico da Costa e Artur do Cruzeiro Seixas, este texto exalta, mais uma vez o poder da imaginação e importância de sua aplicação ao real" (TCHEN, 2001, p. 128).
} 
Salvo o PC, mesmo estruturado por honra-da-firma internacional, não havia nenhum túnel em que valesse a pena enfiar o pescoço e ocultar a alma. Só então a clandestinidade, que respeitei sempre nos que a assumem, mas cedo vi nela um processo de temerária praticabilidade, em que muito se corrompe, porque a verdade, de qualquer maneira, adiada, permite que nela se instalem quebras de sigilo em briga com as necessidades de estratégia interna que causam também dúvidas, desconfianças e traições táctitas. ${ }^{148}$

Alguns dos poetas surrealistas, como Pedro Oom e António Maria Lisboa, já haviam alertado para o perigo de o movimento se reduzir a um conjunto de técnicas, convenções e procedimentos estéticos, defendendo, assim, uma "posição abjeccionista", em que o escritor exigisse para si o estatuto de "insubmissão permanente ante os conceitos, regras, e princípios estabelecidos" ${ }^{149}$. Será esse o contexto que prepara, a partir de 1955, o surgimento de uma segunda geração surrealista, formada por artistas que se encontravam no chamado Café Gelo em Lisboa. Conforme explica Fernando J. B. Martinho, essa geração estava ligada àquilo que Mário Cesariny identificava como “abjeccionismo conjuntural": experiência trágica da vida e da arte; expressão de inclinações negativistas, autodestrutivas e niilistas (MARTINHO, 1996, p. 80). Como exemplo mais elucidativo, o crítico cita o livro de António José Forte, Quarenta noites de insônia..., que estampava na capa as palavras de Pedro Oom, "o que pode fazer um homem desesperado quando o ar é um vómito e nós seres abjectos", adotadas como lema por muitos artistas da geração.

Embora publicado alguns anos antes do surgimento dessa segunda geração, o terceiro livro da coletânea de Poemas também capta e exprime essa "consciência da abjecção", que será mais claramente articulada pelos artistas do Café Gelo. Sobretudo porque também procura se definir pela negativa e pela clandestinidade, rejeitando os valores morais e sociais, e recusando a "condição mais comum", segundo mais tarde declararia Manuel de Castro: "Nós os intocáveis, os imundos, recusamos / nossa condição comum”, ou Alexandre O’Neill em "Um adeus português”: “[...] um país onde os homens são só até o joelho". ${ }^{150}$ Como veremos na análise dos poemas abaixo, a conjuntura social é retratada com realismo: o cenário é devastador. A realidade

\footnotetext{
${ }^{148}$ Mário Cesariny, entrevista em Jornal da Letras, agosto, 1982, pp. 3 a 16. Ver também carta de M.H. Leiria a C. Eurico da Costa: "[...] Nós, se quisermos seguir, teremos que combater acompanhados por todos os que por, ânsia, e desejo, também querem como nós, livrar-se da opressão que diariamente nos é posta nos olhos, na boca, no sexo, no corpo todo" (TCHEN, 2011, p. 140).

${ }_{149}$ Pedro Oom, citado por Fernando J.B. Martinho, 1996, p. 64.

${ }^{150}$ Versos citados por Fernando J.B. Martinho, 1996, pp. 50 e 80.
} 
histórica, situada no Portugal da ditadura e da censura, revela-se "abjecta". Contudo, percebe-se ainda uma aposta na capacidade de resistência da linguagem e na exaltação do amor. Identificamos, por conseguinte, o movimento constante de revisão da poética eugeniana, que, mesmo pelo revés e pela tangente de um dizer "interdito", procura afirmar os poemas como um "ato" poético.

Nesse sentido, muitas composições de As palavras interditas encenam a situação de escrita. Com grande frequência encontramos aludida, de um modo ou de outro, a figura do poeta em ação, às vezes em linguagem mais ou menos literal, como em: "É a hora de fazer milagres: / posso ressuscitar os mortos e trazê-los / a este quarto branco e despovoado, / onde entro sempre pela primeira vez, / para falarmos das grandes searas de trigo" ("Os olhos rasos de água", 1966, p. 115), ou em: "Neste quarto, agora habitado pelo vento; / [...] Aqui estou, alto como o trigo" ("Elegia e destruição", 1966, p. 111); e outras vezes, a cena realista dilui-se no fluxo metafórico do poema:

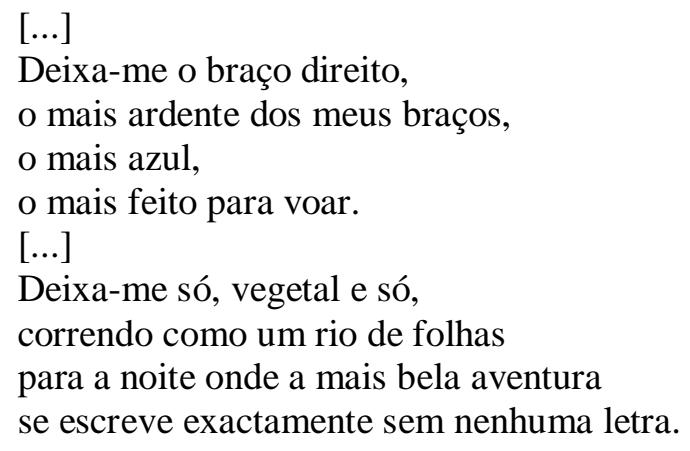

(ANDRADE, "Vegetal e só", 1966, p. 109)

Em certas ocasiões, o poeta reflete sobre o ato poético com voz lúcida e consciente: "Por isso escrevo esta elegia, / como quem oferece a luz dos olhos" (1966, p. 119); em outras, convoca à cena da escrita alucinações, sonhos, fantasmas pessoais: "Como se houvesse uma tempestade / escurecendo os teus cabelos" (1966, p. 100).

Em um livro cujo título aponta para a imposição de um obstáculo à escrita, como é o caso de As palavras interditas, é significativo o fato de o ato poético ser obsessivamente reiterado. Conforme discorre Rosa Maria Martelo:

As cenas de escrita nunca são inocentes. [...] Elas indiciam sempre uma poética e também uma ética da escrita. Com efeito, a questão de onde e como se escreve não é inócua nem destituída de sentido, 
sobretudo quando o acto da escrita é tematizado num poema. Faz parte da dimensão meta-reflexiva da poesia de tradição moderna a apropriação das cenas de escrita como um dos tópicos através dos quais a poesia se dobra sobre si mesma e a si mesma se mostra, pensa e analisa [...]. E não é por acaso que uso aqui a palavra cena, com tudo quanto ela tem de alusão ao teatro, pois a especularidade da escrita que absorve o acto de escrever, ou que o figura, tem algo de cenografia, de uma ceno-grafia. Quando um poema se transforma em cena de escrita, o que nos é dado ver é sempre a poética que lhe está subjacente $[\ldots]^{151}$

Embora, talvez, não possamos falar de um contexto propriamente metalinguístico na poesia eugeniana - já que o tema da palavra é geralmente apresentado em condição de coincidência com outros temas, como temos visto, confundindo-se, principalmente, com a expressão amorosa -, o ato da escrita surge, nesse volume, dramatizado. A situação da escrita é frequentemente encenada, por onde se explicita a vontade de dizer, a vontade de romper com o contexto opressor e a proposta de reconquistar algo que à primeira vista parece já derrotado.

Desse modo, podemos falar de um "cenário" que ronda quase todo o conjunto dos poemas: uma "cidade bombardeada", feita de "pedra escura", "ruas álgidas" em que "ondas de sombra quebram nas esquinas", "montes de carvão", "vendedores ambulantes", "cigarros e gente sem destino", "arcos e arcos de solidão", e o "tempo a

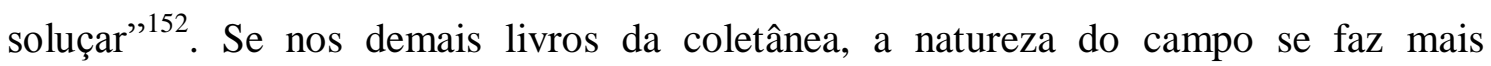
presente, nesse livro encontramos caracterizado, de maneira predominante, o espaço urbano: local em que as diferenças são mais latentes, em que as trocas e as intercomunicações culturais, sociais, políticas são possíveis, e onde há, portanto, maior resistência à ideologia fascista, assente, sobretudo, no sentimento patriótico de unidade. $^{153}$

151 "Cenas de escrita (alguns exemplos)". A forma informe: leituras de poesia. Lisboa: Assírio \& Alvim, 2010 , p. 323.

152 "Cidade bombardeada", "pedra escura" e o verso "ondas de sombra quebram nas esquinas" pertencem ao primeiro poema, na página 98. "Ruas álgidas" é trecho do prefácio, na página 97. "Vendedores ambulantes" e "cigarros e gente sem destino" encontram-se na página 117. "Montes de carvão", "arcos e arcos de solidão" e "tempo a soluçar" estão, respectivamente, nas páginas 108, 103 e 112.

${ }_{153}$ "[...] A ideologia fascista apresentava uma solução monopartidária, em que a ordem económica e social era dominada por um governo forte ao serviço da nação. As estruturas tradicionais e conservadoras eram fortalecidas em prol da valorização das tradições e da raça, promovendo-se um sentimento de unidade em que as diferenças eram ultrapassadas pelo patriotismo comum. Foi essencialmente nos países onde se implantaram regimes fascistas, como na Espanha de Franco, na Itália de Mussolini ou na Alemanha de Hitler, bem como nos estados por esses subjugados, que o surrealismo encontrou maior oposição" (TCHEN, 2001, p. 40). A poesia eugeniana, de maneira semelhante ao que Tchen aponta como 
Os fragmentos ou ruínas da cidade concorrem com as marcas da ausência de um "personagem" que partira recentemente e a quem ainda se procura obsessivamente. Diante desse quadro, a voz lírica se autoconvoca, em primeira pessoa, a atravessar o cenário de devastação para penetrar a solidão de seu quarto branco e buscar, na escrita, uma cena de reencontro. É através desse ato principal que a escrita eugeniana se autoencena nesse livro, repetindo-se sob diversos ângulos e exibindo, ainda que às vezes discretamente, os rastros de seu esforço ao longo dos quatorze poemas.

Assim, logo na primeira linha do prefácio, "Primeiramente", há o contorno de uma ausência, de uma fissura:

\begin{abstract}
Acordo sem o contorno do teu rosto na minha almofada, sem o teu peito liso e claro como um dia de vento, e começo a erguer a madrugada apenas com as duas mãos que me deixaste, hesitante nos gestos, porque os meus olhos partiram nos teus.

E é assim que a noite chega, e dentro dela te procuro, encostado ao teu nome, pelas ruas álgidas onde tu não passas, com a solidão aberta nos dedos como um cravo.

Meu amor, amor de uma breve madrugada de bandeiras, arranco a tua boca da minha e desfolho-a lentamente, até que outra boca - e sempre a tua boca! - comece de novo a nascer na minha boca.

Que posso eu fazer senão escutar o coração inseguro dos pássaros, encostar a minha face ao rosto lunar dos bêbados e perguntar o que aconteceu...
\end{abstract}

(ANDRADE, 1966, p. 97)

O prefácio evoca uma imagem comum na poesia eugeniana, desde o poema de abertura de As mãos e os frutos, em que os "olhos" e as "mãos" dos amantes se entrelaçavam em "estrelas penduradas nos meus dedos". Porém, agora, os mesmos signos compõem uma imagem despedaçada: os "olhos" partiram; restaram apenas "duas mãos", "gestos hesitantes" e "a solidão aberta nos dedos como um cravo".

Ainda assim, o eu lírico apresenta seu projeto de persistir no que poderia ser o trabalho poético de "erguer a madrugada" com apenas "as duas mãos que me deixaste" a fim de suplantar o isolamento e a ausência deixados pela partida recente de um "tu". A solidão é, portanto, anunciada como foco de resistência, começo possível de toda palavra poética e o modo encontrado pelo sujeito para lidar com a derrota do contexto histórico em Portugal.

característica da poesia surrealista, se debruça, em As palavras interditas, sobre tudo aquilo que se constitui como diferença em uma sociedade que se quer homogênia e conservadora. 
Conforme assinala María Zambrano, "escrever é defender a solidão em que se está" ${ }^{154}$ : ação que nasce de um "isolamento comunicável" em que o sujeito toma distância das coisas concretas para poder ver, entre elas, as relações. No caso de $A s$ palavras interditas, escrever na intimidade do quarto ou do ambiente interior, como parece ser este, descrito no prefácio, é defender a posição de um "isolamento comunicativo" que faça frente à impossibilidade geral de comunicação no contexto totalitário português. Ou seja, é defender a liberdade da solidão contra a ordem coletiva, opressora e censuradora do regime. Por conseguinte, escrever é também defender o "silêncio" e o "interdito", quase sempre vencidos pela "fala oficial" e ideológica, mais a favor das circunstâncias e dos interesses imediatos:

\begin{abstract}
Falamos porque algo nos compele e a ordem que nos é dada vem de fora, de uma armadilha em que as circunstâncias pretendem caçar-nos, e a palavra livra-nos dela. Pela palavra tornamo-nos livres, livres do momento, da circunstância assediante e instantânea. Mas a palavra não nos recolhe, nem, portanto, nos cria e, pelo contrário, o muito uso que dela fazemos produz sempre uma desagregação; vencemos pela palavra o momento e depois somos vencidos por ele, pela sucessão dos momentos que vão levando consigo o nosso ataque sem nos deixar responder. [...] Escreve-se para reconquistar a derrota sofrida sempre que falamos longamente. E a vitória somente pode dar-se ali onde se sofreu a derrota, nas mesmas palavras. Estas mesmas palavras terão agora, no escrever, uma função diferente; não estarão ao serviço do momento opressor.
\end{abstract}

(ZAMBRANO, 2000, p. 37)

Nas mesmas "palavras interditas" 155 que o título do livro evoca se posiciona agora o sujeito poético, a procurar, através da escrita, pelo "nome" do amado. Como é constante nessa poesia, esse prefácio também se fundamenta no desejo erótico e na

154 "Porque se escreve". A metáfora do coração. Lisboa: Assírio \& Alvim, 2000, p. 37.

${ }^{155}$ Evocamos aqui também a reflexão de Maurice Blanchot sobre a relação entre solidão e escrita. Tal reflexão pode ajudar-nos a compreender melhor o imperativo histórico do debruçar-se do sujeito poético eugeniano sobre as "palavras interditas": "A solidão que acontece ao escritor por força da obra revela-se nisto: escrever é agora o interminável, o incessante. O escritor já não pertence ao domínio magistral em que exprimir-se significa exprimir a exatidão e a certeza das coisas e dos valores segundo o sentido dos seus limites. O que se escreve entrega aquele que deve escrever a uma afirmação sobre a qual ele carece de autoridade, que é ela própria sem consistência, que nada afirma, que não é o repouso, a dignidade do silêncio, pois ela é o que ainda fala quando tudo foi dito, o que não precede a palavra, porquanto, na verdade, impede-a de ser palavra iniciadora, tal como lhe retira o direito e o poder de interromper-se. [...] [Escrever] É, além disso, retirar a palavra do curso do mundo, desinvesti-la do que faz dela um poder pelo qual, se eu falo, é o mundo que se fala, é o dia que se identifica pelo trabalho, a ação e o tempo. [...] O escritor pertence a uma linguagem que ninguém fala, que não se dirige a ninguém, que não tem centro, que nada revela.[...] Escrever é entregar-se ao fascínio da ausência do tempo. Neste ponto, estamos abordando, sem dúvida, a essência da solidão”. O espaço literário. Rio de Janeiro: Rocco, 1987, pp. 16, 17 e 20. 
vontade de coincidência. No entanto, o amor de que tratará As palavras interditas é apresentado como uma força ainda mais subversiva, por ser declarado como um "segredo" - embora, admita-se aqui, a afirmação de Octavio Paz de que todo amor apresenta uma ruptura, uma violação da ordem social, "um desafio aos costumes e às instituições da comunidade. É uma paixão que, ao unir os amantes, os separa da sociedade" (PAZ, 1994, p. 103). ${ }^{156}$

A imagem erótica seguinte poderia aludir tanto à celebração do encontro amoroso quanto à origem do canto: "arranco a tua boca da minha e desfolho-a lentamente, até que outra boca - e sempre a tua boca! - comece de novo a nascer na minha boca". O último trecho estabelece as coordenadas desse terceiro livro, cuja poesia persiste no espírito de busca e transformação, e faz sobressair agora, como nunca, o tom de inquirição, principalmente por deter-se aqui nas próprias marcas da ausência, no espaço vazio e fragmentado em que o sujeito se encontra, hesitante, mas esperançoso quanto ao poder unitivo e reconciliador da linguagem. As imagens finais "coração inseguro dos pássaros" e "rosto lunar dos bêbados" descrevem movimentos oscilantes, de perambulação.

Pelo ambiente despedaçado, lança-se a poesia, encenando seu próprio esforço desesperado, à procura pelo "rosto" e pelo "nome" do amado. Nesse sentido, o signo mais trabalhado nesse livro é o do "navio" ou "barco"157 à deriva na cidade, flutuante entre as duas "margens nuas": de um lado, o ambiente noturno e desumanizado da cidade, do outro, a procura pelo encontro privado entre os amantes:

\section{As palavras interditas}

Os navios existem, e existe o teu rosto encostado ao rosto dos navios. Sem nenhum destino flutuam nas cidades, partem no vento, regressam nos rios.

\footnotetext{
156 A referência ao "peito liso e claro" no prefácio acima poderia sugerir a figura de um amante masculino, embora tal leitura resulte em uma interpretação muito subjetiva, já que a descrição é insuficiente para tal caracterização. No entanto, defendemos que, pela da questão do "interdito" e da referência a um "segredo", como veremos mais adiante, o amor aqui tratado parece ser entre dois homens, ou seja, um amor não permitido socialmente. No entanto, a denúncia que As palavras interditas fazem em relação à supressão geral do amor e dos afetos em um contexto totalitário se estende a qualquer amor universal e verdadeiro. Cf. Nota 140.

${ }^{157}$ Em um total de quatorze poemas, o "navio" ou o "barco" aparecem em oito: "As palavras interditas", "Litania", "Canção", "Viagem", "Não é verdade", "Procuro-te”, "Os olhos rasos de água" e "Rosto afogado". Algumas vezes, mesmo quando não diretamente nomeados, são sugeridos por palavras que pertencem ao mesmo campo semântico, como os verbos "singrar" em "Adeus" e "flutuar" em "Postscriptum", e o vocábulo "mar" em "Mar, mar e mar".
} 
$\mathrm{Na}$ areia branca, onde o tempo começa, uma criança passa de costas para o mar. Anoitece. Não há dúvida, anoitece. É preciso partir, é preciso ficar.

Os hospitais cobrem-se de cinza. Ondas de sombra quebram nas esquinas. Amo-te... E entram pela janela as primeiras luzes das colinas.

As palavras que te enviam são interditas até, meu amor, pelo halo das searas; se alguma regressasse, nem já reconhecia o teu nome nas suas curvas claras.

Dói-me esta água, este ar que se respira, dói-me esta solidão de pedra escura, estas mãos nocturnas onde aperto Os meus dias quebrados na cintura.

E a noite cresce apaixonadamente. Nas suas margens nuas, desoladas, cada homem tem apenas para dar um horizonte de cidades bombardeadas.

(ANDRADE, 1966, p. 98)

A confirmação de que "os navios existem" surge como um contraponto ao sentimento de fragmentação do presente: o "navio" parece ser a única coisa que "existe" e que possui inteireza em meio às ruínas de uma cidade que lembra a "terra desolada" do cenário do pós-guerra, em que "hospitais" se cobrem de "cinzas" e "ondas de sombra". O ar é pesado, a "noite cresce" e encobre certas imagens luminosas que, em sequências fragmentadas, se apresentam ao longo dos versos: "areia branca", "primeiras luzes das colinas", "halo das searas"158 "curvas claras". Esses estilhaços de "luz" aos

\footnotetext{
158 "Seara" poderia fazer uma alusão indireta ao grupo dos "poetas militantes" que se dispunham contra o fascismo salazarista, já que Nova Seara era o nome da revista fundada em 1921, em Lisboa, pelo "Grupo da Biblioteca Nacional", formado por intelectuais como Jaime Cortesão, Raul Proença, Raul Brandão, Aquilino Ribeiro, Câmara Reis e Augusto Casimiro. Conforme explica Raquel S. Madanêlo Souza: "Essa publicação tinha como foco principal a promoção de uma reforma da mentalidade portuguesa, através da crítica e análise da situação educacional, política, econômica e social do país; da proposição de soluções para essas questões relacionadas à crise nacional e de uma tentativa de ação reformadora, de caráter pedagógico-doutrinário. [...] O objetivo do grupo seareiro seria o de transformar os intelectuais em membros ativos no processo de reestruturação da pátria: 'Serão poetas militantes, críticos militantes, economistas e pedagogos militantes. [...] Muito tempo passaram já os homens de elite isolados do povo, fora das realidades sociais, muito para além do plano e do movimento em que se tece o futuro do mundo'. Por esse breve trecho do editorial é possível perceber que o uso repetido do adjetivo 'militante', para caracterizar seja economistas, seja pedagogos, seja os poetas, revela o peso da ideia de 'ação' no programa de reforma proposto naquele momento. E essa mesma ação, quando pensada em relação ao campo literário, nesse contexto, implica a entrada em uma temática fundamental do campo da estética: a
} 
poucos se extinguem nas "mãos nocturnas" e na "solidão de pedra escura": "Anoitece.

Não há dúvida, anoitece”.

O "navio" é um signo que possui a inteireza de um símbolo ou de uma metáfora $^{159}$, em meio a outros elementos espedaçados da paisagem, que funcionam como espécies de "alegorias" modo, apresentando-se como um veículo de fuga, de exílio, de saída de um país tornado inabitável, o "navio" evoca um espaço de maior inteireza, em que talvez seja possível experimentar uma realidade alternativa à desolação do entorno ${ }^{161}$. No entanto, está "à deriva", "sem destino", levando encostado ao seu o "rosto do amado", flutuando e "regressando" nos rios, e apresentando-se, portanto, como veículo de separação dos amantes. Dessa maneira, associado a uma vida clandestina, de fuga, exílio ou mesmo saída para a guerra, o "navio" se distancia da visão idílica geralmente evocada, ou da imagem gloriosa da nação. ${ }^{162}$ À deriva, ele permanece no centro de uma imagem

chamada função da arte". Em "Raul Brandão na revista Seara Nova". Revista Crioula. N. 2, São Paulo, novembro, 2007. No poema acima, o verso "As palavras que te enviam são interditas/até, meu amor, pelo halo das searas" poderia fazer alusão às notícias sufocadas, à inutilidade das palavras, mesmo da poesia engajada e militante dos neorrealistas.

${ }^{159}$ Na definição de Rosa Maria Martelo, o "símbolo" ou a "metáfora", apesar das diferenças, revelam, ambos, certa "essência" capaz de conter em si mesma a parte e o todo da substância que representa, estabelecendo, por isso, uma relação de unidade com o mundo. Cf. nota 160.

${ }^{160}$ Rosa Maria Martelo discorre sobre a diferença entre o símbolo e a metáfora, de um lado, e a alegoria, de outro: "Próprio do símbolo, como atesta a etimologia, é o lance simultâneo, o lançar conjuntamente, de que a metáfora guarda, identicamente, a valorização da produtividade que decorre da intersecção de dois reinos diferenciados, mas unidos num terceiro; próprio da alegoria é o lance que se faz em vez de, e por conseguinte, no reconhecimento de nesse movimento haver sempre uma vertente de perda, uma dimensão que não comparece". Vidro do mesmo vidro. Porto: Campo das Letras, 2007, p. 96. Martelo abraça a "reapreciação" da alegoria (desvalorizada pela tradição crítica desde o Romantismo) por parte de Walter Benjamin e mais tarde por Paul de Man e Craig Owens. Esses autores foram responsáveis por investigar a alegoria não mais como uma figura de linguagem meramente ornamental e estilística, mas como um "formante de uma relação com o mundo e, por conseguinte, também uma condição da apresentação dessa relação" (MARTELO, 2007, p. 89). Nessa perspectiva, o "olhar do alegorista" expressaria a experiência de perda irredimível em relação ao tempo: ao debruçar-se sobre a própria "fissura", sobre a separação em si mesma, manifestaria a perda e a "distância de sua própria origem", estabelecendo "a sua linguagem no vazio dessa diferença temporal" (MARTELO, 2007, p. 96). Em As palavras interditas, a alegoria é a figura mais frequentemente empregada na descrição da paisagem urbana, no centro da qual habita o sujeito incompleto e angustiado, à procura de uma unidade reveladora do ser. Por outro lado, o signo central do "navio" mantém a inteireza de um símbolo ou de uma metáfora - embora encene, à deriva, a impossibilidade do encontro esperado com outros constituintes imagéticos, permanecendo no centro de uma imagem fragmentada do mundo.

${ }^{161}$ Sobre este poema, Eduardo Prado Coelho escreveu: "O navio dentro da cidade parece transmitir uma relação de um lugar de resistência frente à ruína e a opressão: navios que, atravessando o desespero, a ditadura e a morte, permitem a passagem dos passageiros clandestinos que a eles se encostam e das mensagens que eles enviam, palavras interditas - notícias de bloqueio". "Relatório duma leitura da poesia de Eugénio de Andrade, e do prazer que ela provoca no leitor". 21 ensaios sobre Eugénio de Andrade. Porto: Editorial Inova, 1971, p. 74.

${ }^{162}$ Conforme demonstra João Adolfo Hansen, a viagem do "navio" por mar é um lugar comum alegórico, como na Ode XIV de Horácio, em que o "navio" alegoriza Roma: "É lugar comum muito usual o da 
fragmentada do mundo. No vaivém indeterminado, entremeio entre o "claro" e o "escuro" frequentemente contrastados no poema ${ }^{163}$, se posiciona a voz lírica: "É preciso partir, é preciso ficar".

Uma poesia que se caracteriza pela autovigilância e capacidade de transformação, que pretende afirmar-se contra a ausência, resistir à opressão humana e à "amputação do corpo e da vida", conforme declarado em "Poética", propõe também aqui a procura pelo "verdadeiro rosto humano". Porém, como demonstra esse poema, divide-se entre a vontade do "sim" e o sentimento de negação que habita os "dias quebrados na cintura" e o "horizonte de cidades bombardeadas". Ao pronunciar "Amote", "as primeiras luzes da colina" entram pela janela, mas vagueiam sem destino, sem conseguir se consubstanciar em palavra poética, e o "nome" do amado perde-se nas "curvas claras".

A distância de toda origem é anunciada na imagem: "Na areia branca, onde o tempo começa, / uma criança passa de costas para o mar" ${ }^{164}$, cujos constituintes, que formariam uma unidade arquetípica, se desagregam, mimetizando a profunda dissolução do mundo e do sujeito. O signo "criança" também tem a espessura simbólica de um "navio"; porém, do mesmo modo que este flutua sem destino, ela caminha "de costas" para outros referentes, retrocedendo o processo de encontro e realização da imagem poética. O mesmo signo também aparece em outros poemas, como "criança cega / aos tropeções dentro de ti", "criança adormecida" e "sem nenhuma criança acordada" 165.

Por conseguinte, o "navio" a flutuar pela cidade, em alguns poemas, "barco perto, distante, perdido" (1966, p. 102), associa-se, por um lado, à errância urbana e à

travessia por mar, ilustrado pela ode de Horácio, também significando o destino pessoal ou o ato mesmo de compor um poema". Alegoria. São Paulo: Hedra/Editora da Unicamp, 2006, p. 32. Em As palavras interditas, o "navio" é recuperado alegoricamente para significar os destinos da nação portuguesa, tendo, desde os descobrimentos, se tornado uma das imagens mais carregadas no imaginário português. No entanto, o sentido de "alegoria" que evocamos e que mais se expressa em As palavras interditas é aquele re-significado por Baudelaire, o qual Walter Benjamin definiu como "destruição do orgânico e extinção da aparência": fragmentos e ruínas daquilo que outrora salvaguardava o mito. Assim, em contraste com os demais elementos da paisagem, preferimos chamar de "símbolo" o "navio" do poema "As palavras interditas", embora ele certamente possua a inteireza da "alegoria" como entendida pelos antigos: figura ornamental, que não se distinguia do símbolo na tradição greco-latina, medieval e renascentista, conforme explica Hansen (HANSEN, 2006, p. 15). Para evitar confusão, portanto, estamos denominando o "navio" de "símbolo", em contraste com os demais elementos fragmentados da paisagem, lidos como "alegorias modernas".

${ }^{163}$ Contrastes marcados ao longo de todo o poema: "ondas de sombra" X "primeiras luzes das colinas"; "anoitece" x "areias brancas"/ "halo das searas"; "água” x "pedra"; "mãos nocturnas" x "dias quebrados na cintura"; partir x ficar; partir x regressar, unidade x ruína; "mar" x "cidade".

${ }^{164} \mathrm{~A}$ imagem aqui poderia também se referir à recusa da juventude de seguir pelo mar, associado no imaginário português à saída para a guerra ou para as colônias, a serviço da nação.

165 Respectivamente: p. 100, p. 101 e p. 109. 
experiência do não lugar, em As palavras interditas, mas também sugere, por outro lado, um espaço de resistência, em que é possível navegar, ainda que sem destino. Ora comparado ao corpo do amado que parte, como em "Reconheço o teu corpo [...]/ flutuando sem limites na espessura / da noite" $\left(1966\right.$, p. 123) ${ }^{166}$, ora equiparado à palavra poética ou a um "pássaro", como em "Um pássaro e um navio são a mesma coisa / quando te procuro de rosto cravado na luz" (1966, p. 114), o "navio" faz-se presente em muitos poemas do livro que se demoram sobre o movimento de partida e separação, como sugerem os títulos de certas composições: "Viagem", "Mar, mar e mar", "Adeus"; ou os versos "amor de uma viagem nocturna", "A minha morte é este vaguear contigo", "onda e outra onda e outra / desfaz o seu corpo azul contra o meu corpo". ${ }^{167}$ Em poemas como “Adeus", "Litania" ou "Viagem", a lenta movimentação de partida é anunciada: por vezes, a voz lírica parece entoar do próprio "navio" que parte, outras vezes da praia onde o sujeito vê o navio seguir seu rumo.

Em alguns momentos, essa "viagem escura" do "navio" coincide claramente com o destino do país, como no sétimo poema, "Não é verdade", em que o eu lírico "sonha" o "país crescendo em liberdade / aureolado de trigo e alegria", em meio à realidade de desolação, opressão e morte, que ameaçam penetrar, inclusive, os únicos espaços de resistência: "a morte passeia nos quartos, ronda as esquinas, entra nos navios". Diríamos que esse verso sugere a presença do que poderia ser os órgãos de vigilância política ${ }^{168}$, talvez frequentes no Portugal da década de 1950, a censurar e

\footnotetext{
${ }^{166}$ Ou no belo poema, "Litania", terceiro do livro, em que se dá o procurado encontro com o corpo do amado através da escrita: "Iluminou-se o teu corpo na noite, / o teu corpo, mar azul de ser tão branco, / caminhando ao meu encontro / [...] Meu amor!, / amor de uma viagem nocturna / no colo das andorinhas, /iluminou-se o teu corpo na noite! Iluminou-se com a palavra exacta / que muda os cavalos em rios, /os rios em aves, / as aves na tua boa! / [...] Iluminou-se o teu corpo, / o teu corpo, / irreal como um barco, /perto, distante, perdido, [...]" (ANDRADE, 1966, p. 101). Tanto a imagem do navio quanto o verso "no colo das andorinhas" admitem uma leitura intertextual com Anthony and Cleopatra, de William Shakespeare. Na tragédia, algumas andorinhas fazem ninho na vela do barco de Cleópatra pouco antes da última batalha em que Octávio César derrota Marco Antônio. O sinal é interpretado como mau agouro pelos tripulantes. Ao decidir seguir cegamente o barco de sua amada, que já navegava para longe da batalha, Marco Antônio perde a guerra e a posse do Império Romano. Seu amor por Cleópatra torna-se emblemático em As palavras interditas, por se opor, de maneira trágica, a Roma e suas pressões políticas. Cf. Antony and Cleopatra. London: the Arden Shakespeare. 2006, p. 203. Embora não tenha se referido nem a esse verso nem ao terceiro livro de Poemas, João de Mancelos foi o autor que nos chamou a atenção para a relação entre as "andorinhas" eugenianas e a peça de Shakespeare ao mencionar o poema "Estas areias" do livro Memória doutro rio, de Eugénio de Andrade. Ali, o poeta tece uma dedicatória aos dias de verão, ao primeiro amor, aos gatos, ao avô, etc., e à andorinha de Shakespeare: "A uma andorinha, a todas as andorinhas que, / no dizer de Shakespeare, fizeram ninhos nas naves / de Cleópatra”. Mancelos interpreta a referência a essas aves como "um artifício poético destinado a vincar a efemeridade de todos os momentos agradáveis". O marulhar de versos antigos. Lisboa: Edições Colibri, 2009, pp. 20 e 21.

${ }^{167}$ Respectivamente: dos poemas "Litania", p. 101; "Rosto afogado", p. 117; e "Mar, mar e mar", p. 120.

168 Mais adiante, na nota 172, explicamos mais detalhadamente a relação que estabelecemos entre a
} 
reprimir qualquer comportamento considerado suspeito ou subversivo: "Não é verdade tanta rosa decepada, / tanta ponte de fumo, tanta roupa escura, / tanto relógio, tanta pomba assassinada!” (1966, p. 108). Além do tempo linearmente marcado (representação opressora da "morte"), o "relógio" também poderia remeter à presença de uma ordem controladora, talvez vestida de farda ("roupa escura") a suprimir qualquer gesto de doçura ("rosa decepada") e liberdade ("pomba assassinada"). E a reprimir, principalmente, este amor tido como proibido: "Não quero para mim tanto veneno, / [...] nem olhos pintados onde morre o dia, / nem beijos de lágrimas no meu cabelo!"169 (ANDRADE, 1966, p. 108).

Porém, ao fim do poema, ao contrário de "As palavras interditas", em que o tom cético prevalece, a escrita surge como esperança: "Amanhece..., um galo risca o silêncio / desenhando o teu rosto nos telhados. / Eu falo do jardim onde começa / um dia claro de amantes enlaçados" (ANDRADE, 1966, p. 108). Tanto o "sonho" quanto o "dizer do poeta" afirmam a força do amor e do erotismo contra a dura realidade histórica.

De modo semelhante, em diversos poemas do livro a voz lírica se lamenta, tomada por medo, desespero e tristeza. No entanto, revela, ainda que por meio de fragmentos luminosos, confiança na capacidade de resistência da escrita, como nestes trechos de "Elegia e destruição", nono poema do livro:

$$
[\ldots]
$$

Trouxe comigo um cheiro a resina.

Trouxe também os juncos vermelhos ${ }^{170}$

\begin{abstract}
poesia de As palavras interditas e o problema da ditadura em Portugal.
${ }^{169}$ Esses versos finais estabelecem, mais uma vez, a comparação entre o amor cantado em As palavras interditas e a paixão trágica entre Cleópatra e Marco Antônio (cf. nota 166), já que parecem fazer referência ao desfecho da peça, em que Cleópatra decide se envenenar com a picada de uma serpente após a derrota e a morte de Marco Antônio. Seu corpo é encontrado ao lado de duas criadas, que também levam picadas. Uma delas ainda está viva e chora, trançando o diadema de Cleópatra.

${ }^{170}$ A expressão "juncos vermelhos", assim como "no colo das andorinhas" referida acima, traz à escrita eugeniana elementos intertextuais, nesse caso da poesia oriental (Cf. http://www.capparelli.com.br/libai.php sobre a poesia de Li Bai, acesso em 1/11/2011) presentes também em diversos momentos de sua poesia, como no poema "Nocturno", de As mãos e os frutos, quase um haicai: "Coaxar de rãs é toda melodia / que a noite tem no seio / - versos dos charcos / e dos juncos podres, / casualmente, com luar no meio" (ANDRADE, 1966, p. 45). O recurso à intertextualidade também é outra maneira de encenar a escrita, já que cada associação faz lembrar ao leitor que todo texto pressupõe uma escolha, um lugar, uma perspectiva. No exemplo de "Nocturno", o poeta assenta o espaço do poema ("versos dos charcos") na relação intertextual, e no poema analisado acima, refere-se aos elementos "trazidos" de leituras anteriores à cena da escrita. Ou seja, ambos remetem ao processo contínuo e de certo modo infinito da escritura, posicionado entre aquilo que Fernando Guimarães denominou "possibilidade e necessidade" de sentido: "É certo que a linguagem de um poema não se limita a ser um sistema de signos; mas importa notar que o conhecimento que essa linguagem vem potenciar está menos relacionada com a presença de um leitor e mais com uma situação de leitura ou, se se preferir, com o desenvolvimento de uma ordem interpretativa derivada de uma expressão simbólica
\end{abstract}


que ladeiam a orla do silêncio, neste quarto, agora habitado pelo vento; e ainda um olhar húmido onde os pássaros perpetuam o céu.

\title{
$[\ldots]$
}

A cidade onde te amei foi decepada e não posso abolir as sentinelas do medo.

Mas também não posso deixar de te querer com beijos e relâmpagos, com sonhos que tropeçam nas paredes e se alimentam só de água pisada, enquanto o tempo persiste em soluçar.

Que me quereis verdes sombras da lua na minha cama onde adormece o frio?

Aqui estou, alto como o trigo, sangrando nas pétalas do dia, e sem receio de que aos nossos gritos ainda chamem brisa...

(ANDRADE,1966, p.111)

A equação difícil entre um real que se pressente em dissolução e a vontade afirmadora da poesia volta a ser apresentada em "Viagem", poema emblemático do livro, em que a palavra é finalmente assumida do alto do "navio", onde se encontram os amantes a perambular pela cidade desolada, singrando o frágil equilíbrio entre os contrastes. Da mesma maneira que no poema de abertura acima, alude-se às "palavras interditas":

\author{
Viagem \\ Iremos juntos separados, \\ as palavras mordidas uma a uma, \\ taciturnas, cintilantes \\ - ó meu amor, constelação de bruma!, \\ ombro dos meus braços hesitantes! \\ Esquecidos, lembrados, repetidos \\ na boca dos amantes que se beijam \\ no alto dos navios;
}

que se apresenta finalmente referida ao texto. Por isso a leitura está condicionada pela necessidade da escrita. As leituras de um texto podem conduzir a várias interpretações, as quais permitem a actualização ou a totalização do texto em que se torna compossível o encontro dessas múltiplas interpretações. A escrita tende para este momento de totalização. Encontra-se aí o suporte de uma sobredeterminação de leituras. Dir-se-ia, pois, que a relação que se estabelece em literatura entre necessidade e possibilidade fica repartida entre dois momentos que são, respectivamente, a escrita e a leitura". Fernando Guimarães. "Leitura: entre a necessidade e a possibilidade". A obra de arte e o seu mundo. Vila Nova de Famalicão: Edições Quase, 2007, p. 34. 
desfeitos ambos, ambos inteiros, no rastro dos peixes luminosos, afogados na voz dos marinheiros.

(ANDRADE, 1966, p. 106)

Há uma série de paradoxos reunidos cujo efeito maior é de cisão: compõem uma espécie de intervalo angustiante, de "hiato", cujo centro é representado pelo "alto dos navios" em que se encontram os amantes. A despeito das rimas regulares, o ritmo geral do poema é truncado, obtido pela enumeração de palavras pertencentes a campos semânticos opostos, bem como por repetições como "desfeitos ambos, ambos inteiros", em que a palavra "ambos" alonga o espaço do meio entre as antinomias apresentadas e entre os amantes; intervalo entre o "vaivém" do "navio" que não parte, mas também não permanece; campo entre o claro e o escuro das palavras "taciturnas" e "cintilantes"; "esquecidas" e "lembradas"; "hesitantes". Assim seguem os amantes, "juntos separados", já desfeitos e afogados "na voz dos marinheiros".

O "navio" nesse poema, assim como em "Não é verdade", também parece acenar para o destino da pátria, que conduz os amantes pelo "não governo" de suas próprias vidas. As "palavras mordidas" no poema evocam "as palavras interditas" do título do livro, as quais, a um só tempo, poderiam se reportar à posição de "entremeio" vivida pelo sujeito (palavras "ditas" "entre" alguma coisa), e também à condição de "interdição" da livre expressão, instituída pela política opressora de Salazar, instaurada a partir dos anos 1930.

Como já referido, portanto, o livro expõe a experiência de aniquilação do indivíduo vivida no rastro da Segunda Guerra Mundial e da manutenção do Estado totalitário em Portugal. A voz dos amantes "afoga-se" na voz coletiva e opressora dos "marinheiros", que poderia aludir aos homens do Estado, aos militares no poder e às forças maiores que sobrepujavam as vontades, os desejos e a liberdade dos indivíduos, interferindo também na própria relação amorosa. Assim, o erotismo é explicitado como resistência em diversos momentos do livro, como em: "se preferes, a tua boca clara singrando largamente no meu peito" (1966, p. 100), e nas imagens fálicas como a do "trigo" e das "espadas": "Dificilmente esqueço a rua onde encontrei / os teus olhos imensos, trespassados / pelo fulgor secreto das espadas" (1966, p. 111); “Aqui estou, 
alto como o trigo" (1966, p. 112). ${ }^{171}$

No décimo primeiro poema do livro, "Os olhos rasos de água", há o lamento nos versos iniciais que poderia ser lido nesse mesmo sentido: o eu lírico alude à coibição geral do amor e da poesia por uma sociedade conservadora, organizada em rígidos moldes de comportamento e padrões de vida:

\section{Os olhos rasos de água}

Cansado de ser homem durante o dia inteiro chego à noite com os olhos rasos de água.

Posso então deitar-me ao pé do teu retrato, entrar dentro de ti como num bosque.

É a hora de fazer milagres:

posso ressuscitar os mortos e trazê-los a este quarto branco e despovoado, onde entro sempre pela primeira vez, para falarmos das grandes searas de trigo afogadas na luz do amanhecer.

Posso prometer uma viagem ao Paraíso a quem se estender ao pé de mim, ou deixar uma lágrima nos meus olhos ser toda a nostalgia das areias.

É a hora de adormecer na tua boca.

Como um marinheiro no barco naufragado, o vento na margem das espigas.

(ANDRADE, 1966, p. 116)

O primeiro verso "Cansado de ser homem durante o dia inteiro" remete ao mundo para além do ambiente privado do "quarto branco e despovoado", onde o eu lírico estuda o retrato do amado. Representa assim o espaço coletivo do "dia", do ser social, do ambiente de trabalho, onde se espera certo comportamento masculino tradicional, em uma sociedade organizada nos moldes conservadores e patriarcais como a portuguesa, em que não cabem as paixões e os desejos - ainda mais se homossexuais,

\footnotetext{
${ }^{171}$ Embora em As mãos e os frutos não haja alusão direta a um segredo, como ocorre em As palavras interditas, Alexandre Pinheiro Torres destaca a coincidência, nesse livro, entre a chegada da noite e a chegada do amado: a noite é o momento em que o amante eugeniano descobre a única viabilidade para o seu amor, o que sugere um amor proibido, apartado dos olhos do "dia" e dos outros homens, em "O conflito entre instinto e sociedade", em "As mãos e os frutos de Eugénio de Andrade". 21 ensaios sobre Eugénio de Andrade. Porto: Editorial Inova, 1971, p. 9.
} 
se tomarmos em conta a biografia do poeta. ${ }^{172}$ Aqui, vale a pena mencionar, ainda que brevemente, um trecho do quinto poema do livro, "Retrato com sombra", em que encontramos outra referência ao que parece ser a mesma fotografia, observada com nostalgia e tristeza por se reconhecer, naquela imagem, apenas o "rosto" social do amado, distanciado de sua face mais verdadeira e mais ignorada pelo restante dos homens:

\author{
$[\ldots]$ \\ Falta aqui tudo que amámos juntos, \\ o teu sorriso com as ruas dentro, \\ o secreto rumor das tuas veias \\ abrindo sulcos de luz e de palavras \\ no rosto da noite inesperada. \\ Falta sobretudo à roda dos teus olhos \\ a pura ressonância da alegria. \\ Lembro- me de uma noite em que ficamos nus \\ para embalar um beijo ou uma lágrima, \\ [...] \\ Tu não eras ainda este perfil \\ com uma rosa de cinza na mão direita. \\ $\mathrm{Eu}$ andava dentro de ti \\ como um pequeno rio de sol \\ dentro da semente, \\ porque nós - é preciso dizê-lo! - \\ tínhamos nascido um dentro do outro
}

\footnotetext{
${ }^{172}$ Sobre a questão da repressão do desejo, tão discutida em As palavras interditas, evocamos o conceito de "agenciamento do desejo" que Gilles Deleuze expõe em "Désir et plaisir". Magazine Littéraire, Paris, n. 325, oct, 1994, pp. 57 à 65 . Conforme o filósofo, esta é uma estratégia básica empreendida por todo corpo social e nada tem a ver com as noções de "repressão" ou "ideologia", com as quais viemos trabalhando na análise de alguns poemas deste livro, escrito em plena ditadura salazarista. Deleuze defende o primado do desejo em qualquer organização social, já que é através de seu agenciamento que o corpo social dissemina suas formações ou dispositivos de poder. É também o desejo que realiza aquilo que Deleuze denomina "pontos de fuga" (ou "movimentos de desterritorialização", definidos pelo crítico como determinações coletivas históricas, como as que ocorreram durante o século XI na Europa, por exemplo: as últimas invasões germânicas, as pilhagens, a desterritorialização da Igreja, as migrações camponesas, as transformações da cidade, da moeda, da condição feminina com os temas do amor cortês, etc.), sobre os quais os dispositivos de poder vão atuar e atar. Portanto, Deleuze rejeita o conceito de "resistência", já que as chamadas "linhas de fuga" precedem os dispositivos de poder, surgidos como estratégias de controle e agenciamento do desejo. Sendo assim, "o poder é uma afecção do desejo". Essa explicação de Deleuze nos ajuda a enxergar, de maneira mais complexa, a dolorosa vivência histórica em As palavras interditas, já que esses "agenciadores de poder" não pertencem, necessariamente, a modos concretos de controle, como os órgãos e instituições do Estado totalitário, mas podem existir, sobretudo, como "fantasmas", como define Deleuze, "como coisas vergonhosas", travestidas de normalizações, padrões de comportamento e disciplinas. Assim, o verso "Cansado de ser homem o dia inteiro" constitui um desabafo que transcende o problema da repressão histórica vivido por Portugal durante o regime do Estado Novo, embora também possa aludir a ele diretamente. Do mesmo modo, a questão do homossexualismo se oferece apenas como um ponto de partida para a defesa da libertação e da fruição do desejo que a poesia eugeniana pretende a todo instante levar a cabo. É nesse contexto que inserimos também o verso do poema "Não é verdade", analisado no corpo do texto acima, em que o eu lírico "sonha" o "país crescendo em liberdade / aureolado de trigo e alegria". "Trigo", como temos ressaltado, é uma imagem bastante recorrente e relacionada com a emergência da sexualidade.
} 
naquela noite.

$[\ldots]$

(ANDRADE, 1966, p. 104)

O desabafo "é preciso dizê-lo!", contra a "morte", a "sombra" e a "rosa de cinza na mão direita" (curiosamente semelhante às "rosas brancas" do retrato do menino que a mãe observava em Os amantes sem dinheiro), também ecoa na resolução final do poema, ao revelar o verdadeiro rosto do amado por meio da escrita: "Esse é o teu rosto verdadeiro; aquele rosto que vou juntando ao teu retrato [...] / recortando aqui, /colando ali, até que uma fonte rasgue a tua boca / e a noite fique transbordante de água" (1966, p. 105). "Boca", assim como "fonte", é signo que remete ao canto. Associada à figura do amado, como frequentemente ocorre nesse livro, poderia sugerir também o encorajamento de sua autoexpressão (como no verso "é preciso dizê-lo") e a libertação das "palavras interditas", por intermédio tanto do encontro amoroso como do fazer poético.

Voltando ao poema anterior, "Os olhos rasos de água", observamos que a escrita consegue penetrar o "retrato" para além das aparências, adentrar no "rosto" como em um "bosque", em que se entra para "falar" das "grandes searas de trigo" - imagem recorrente, tradicionalmente ligada à fecundidade ${ }^{173}$, bem como a imagem erótica do verso final: "o vento na margem das espigas" "174. O fazer poético promete uma "viagem ao Paraíso" e sorve a "nostalgia das areias". Porém, a "boca" do amado, desígnio do canto e da expressão dos amantes, revela-se distante e abstrata: nela, o sujeito só pode existir como um "marinheiro num barco naufragado". Tem-se, portanto, apenas um fragmento dessa vivência de plenitude procurada: "o vento na margem das espigas".

No poema seguinte, o "navio" também aparece naufragado, e o "rosto" do amado, tão procurado no transcorrer do livro, encontra-se "afogado":

\section{Rosto afogado}

Para sempre um luar de naufrágio anunciará a aurora fria.

\footnotetext{
${ }^{173}$ Dicionário de Símbolos. Jean Chevalier e Alain Gheerbrant. Rio de Janeiro: José Olympio Editora, 1999, p. 906.

${ }^{174} \mathrm{O}$ poema inteiro celebra o erotismo entre os amantes através de imagens explicitamente sexuais, como "Entrar dentro de ti como num bosque", "É a hora de adormecer na tua boca", "O vento na margem das espigas", etc.
} 
Para sempre o teu rosto afogado, entre retratos e vendedores ambulantes, entre cigarros e gente sem destino, flutuará rodeado de escamas cintilantes. $[\ldots]$

A minha morte é este vaguear contigo na parte mais débil do meu corpo, com uma espinha de silêncio atravessada na garganta.

$[\ldots]$

Quem me dirá que não é verdade o teu rosto afogado, o teu rosto perdido, de sombra em sombra, nas ruas da cidade?

Ninguém te conheceu!

Ninguém viu romper a luz na tua cama!

Ninguém sabe, ai!, ninguém, que o teu corpo, continente selvagem, se desvelava por uma pedra branca atirada contra o nevoeiro!

Por isso escrevo essa elegia como quem oferece a luz dos olhos; por isso canto o teu rosto afogado como quem canta um funeral de espigas.

(ANDRADE, 1966, p. 117)

O verso "Ninguém sabe, ai!, ninguém" parece remeter a um amor secreto. Mais uma vez, aflige-se pelo verdadeiro "rosto" do amante, afogado na brutalidade histórica e social ("retratos"; "gente sem destino"). A vivência luminosa do amor e da poesia só pode se apresentar como fragmentos, "escamas cintilantes" na cidade "despedaçada" entre a banalidade do comércio, de "cigarros" e da "gente sem destino". O vaguear da poesia não trouxe reconciliação, mas sim o sentimento de morte, de aniquilação e dissolução, como "A minha morte é este vaguear contigo" e "Não sei se te procuro ou se me esqueço". Talvez nem a potência da poesia - geralmente creditada pela poética eugeniana como hábil em questionar o estatuto do real e dos modos de vida que nos limitam a uma concepção finita de nossas possibilidades - teve força de desmentir a realidade trágica apresentada ao sujeito, desesperado nesse poema.

Como temos observado, a poesia eugeniana faz sobressair, nesse livro, sua face negativista, manifestada também nas formas poemáticas e nas mudanças de estilo em 
relação aos livros anteriores: sobretudo pela predominância do narrativismo ${ }^{175}$ sobre a tendência epigramática comum em sua poesia, e por certa "intenção alegórica", ou certa "presença do fragmentário" a que nos referimos anteriormente em nota, tal como definida por Rosa Maria Martelo (a partir dos estudos de Walter Benjamin sobre a obra de Baudelaire $)^{176}$, em que o "olhar do alegorista" expressaria a experiência de perda irredimível em relação ao tempo: ao debruçar-se sobre a própria "fissura", sobre a separação em si mesma, manifestaria a perda e a "distância de sua própria origem", estabelecendo "a sua linguagem no vazio dessa diferença temporal" (MARTELO, 2007, p. 96). Desse modo, segundo a autora, a expressão alegórica favorece a contemplação de um fragmento do mundo presente e pobre, sob a "possibilidade de surpreender alguma beleza num mundo reificado e virtualizado, do qual nem sequer a poesia parece poder libertar-se inteiramente" (MARTELO, 2007, p. 100).

No entanto, diante de tantos destroços e desencontros, em que por vezes se declara falência, como no verso "com uma espinha de silêncio / atravessada na garganta" do poema "Rosto afogado" acima, o gesto principal dessa poesia continua sendo o de busca. Pois, ainda no dizer de Martelo, "se assim não fosse, não seria poesia" (MARTELO, 2007, p. 105). Nesse sentido, os dois últimos poemas do livro, "Mar, mar e mar" e "Post-scriptum", evocam o tom de esperança e encanto que pressentimos em poemas como "Litania", terceiro de As palavras interditas, em que se dava, através da escrita, o almejado encontro com o corpo do amado: ${ }^{177}$

\footnotetext{
Post- scriptum

Agora regresso à tua claridade.

Reconheço o teu corpo, arquitetura de terra ardente e lua inviolada, flutuando sem limites na espessura da noite cheirando a madrugada.
}

\footnotetext{
${ }^{175}$ Tal tendência já se faz presente em Os amantes sem dinheiro, embora em meio a outros poemas mais condensados, como é comum em toda a sua obra. Em As palavras interditas todos os poemas são predominantemente longos e discursivos.

${ }^{176}$ Da obra de Benjamin, a autora cita, principalmente, "Parque Central". A modernidade. Edição e tradução de João Barrento. Lisboa: Assírio \& Alvim, 2006; e Origem do drama trágico alemão. Edição e tradução de João Barrento. Lisboa: Assírio \& Alvim, 2004.

${ }^{177}$ Reproduzimos alguns dos versos principais do poema, já transcritos na nota 7: "Iluminou-se o teu corpo na noite, / o teu corpo, mar azul de ser tão branco, / caminhando ao meu encontro / [...] Meu amor!,/ amor de uma viagem nocturna/ no colo das andorinhas, /iluminou-se o teu corpo na noite!/ Iluminou-se com a palavra exacta/ que muda os cavalos em rios, /os rios em aves, / as aves na tua boca!/ [...] Iluminou-se o teu corpo, / o teu corpo, / irreal como um barco, /perto, distante, perdido, [...]" (ANDRADE, 1966, p. 101).
} 
Acordastes na aurora - a boca rumorosa

de um desejo confuso de açucenas;

rosa aberta na brisa ou nas areias,

alta e branca, branca apenas,

e mar ao fundo, o mar das minhas veias.

Estás de pé na orla dos meus versos

ainda quente dos beijos que te dei;

tão jovem!, e mais que jovem, sem mágoa!,

como no tempo em que tinha medo

que tropeçasses numa gota de água.

(ANDRADE, 1966, p. 123)

Os termos "aurora", "areia", "mar ao fundo" e "de pé na orla dos meus versos" fazem lembrar aquela primeira imagem despedaçada do poema de abertura, "As palavras interditas", em que uma criança caminhava na areia branca, de costas para o mar. A "criança" se repete logo em seguida, como vimos, no segundo poema: "criança cega / aos tropeções dentro de ti” (1966, p. 100); versos que, por sua vez, também encontram ressonância no poema acima: "como no tempo em que tinha medo / que tropeçasses numa gota de água". Contudo, há uma mudança essencial: no centro da imagem retomada dá-se, finalmente, o encontro almejado. Não há mais ninguém a caminhar contra o mar, nem a "tropeçar em uma gota de água", como dantes. O amado agora "acorda" na "aurora", com a "boca" finalmente "rumorosa de desejos"; "flutua" na "claridade" e na "espessura" do "mar": levanta-se na "orla dos meus versos".

Em “Mar, mar e mar”, a voz lírica se indaga sobre este lugar de reencontro:

\section{Mar, mar e mar}

Tu perguntas e eu não sei, eu também não sei o que é o mar.

É talvez uma lágrima caída dos meus olhos ao reler uma carta, quando é de noite, sublinhando certas palavras, melancólico.

Os teus dentes, talvez os teus dentes miúdos, brancos dentes, sejam o mar, um mar pequeno e meu,

afável, diáfano,

e contudo só música distante.

É evidente que minha mãe me chama quando uma onda e outra onda e outra desfaz o seu corpo azul contra o meu corpo. Então o mar é carícia, 
asa pura,

luz molhada onde desperta

meu coração recente.

Ás vezes o mar é uma figura branca

cintilando entre os rochedos.

Não sei se fita a água

ou se procura

um beijo entre conchas transparentes.

Não!, o mar não é nardo nem açucena.

É um adolescente morto

de lábios abertos aos lábios da espuma!

É sangue,

sangue onde a luz se esconde

para amar outra luz ou as areias.

Um pedaço de lua insiste,

insiste e sobe lenta arrastando a noite.

Os cabelos de minha mãe desprendem-se,

espalham-se na água,

alisados por uma brisa

que nasce exactamente no meu coração.

O mar volta a ser pequeno e meu,

anêmona perfeita, repetida.

Eu também não sei o que é o mar.

Aguardo a manhã, impaciente,

os pés descalços e leves...

(ANDRADE, 1966, p. 120)

O vaivém do "mar" (“onda e outra onda e outra"), mimetizado em As palavras interditas desde o perambular do "coração inseguro dos pássaros" e do "rosto lunar dos bêbados" do prefácio, até o "navio à deriva", "barco perto, distante, perdido" ao longo do livro, revela-se, aqui, como o espaço incerto do poema: "só música distante", "asa pura", "luz molhada onde desperta / meu coração recente", "figura branca cintilando entre os rochedos". Este último verso se assemelha a "Iluminou-se o teu corpo na noite, / o teu corpo, mar azul de ser tão branco, / caminhando ao meu encontro", de "Litania" (1966, p. 101), em que mais uma vez temos a presença do corpo do amado "caminhando" na "orla dos versos", e o "mar" como uma presença "branca": talvez a sugerir a indagação luminosa que todo papel branco apresenta ao poema, vazio onde tudo começa (ou onde tudo cessa para poder começar) e onde se roça apenas algumas respostas: "talvez uma lágrima caída dos meus olhos ao reler uma carta"; "talvez os teus dentes miúdos"; "carícia"; chamar da mãe. 
O poeta enumera as motivações do poético que desde o primeiro texto da coletânea Poemas conhecemos: a relação com o encontro amoroso, com as memórias (aqui representadas pelas "cartas" e em outros tantos poemas, pelos "retratos") e com a figura materna. Relação com a palavra, tanto vibrada em leituras, como a da "carta" do amado, quanto recolhida em suas unidades essenciais: "luz molhada" (imagem), "música distante" (som), "concha transparente".

Se, em Os amantes sem dinheiro, o sujeito poético se despedira da "mãe" e das "rosas brancas", evocando novos rumos e novos constituintes para sua poesia - as "rosas" agora aparecem nas mãos de um amor declaradamente proibido (em "Postscriptum" analisado acima, a "boca" do amado é referida como "rosa aberta nos areais, alta e branca, branca apenas", perdendo a cor "cinza" com a qual aparecia em "Retrato com sombra") - sua escrita em As palavras interditas encena-se entre ruínas para recompor-se, por fim, no "mar": substrato arquetípico, emblema para uma arte poética em constante fluir e transformação. Assim, tudo aquilo que a poesia eugeniana procurou assimilar deságua agora nas "ondas", libertando-se de antigos fantasmas, como o da "mãe", cujos cabelos se "desprendem" e se "espalham" na "água" (outrora trançados pelo menino em Os amantes sem dinheiro). O poeta atua sobre as "águas" da memória nas quais também imergem, junto da "mãe", a figura do amado ("adolescente morto") -, para que sua poesia possa seguir seu curso e "amar outra luz ou as areias". Por conseguinte, as ondas volvem-se em nova procura, afirmada obstinadamente: "não sei se fita a água ou se procura um beijo entre conchas transparentes".

Nesse sentido, o mar (ou o poema) oferece o desaguar do tempo em reencontro com a unidade arquetípica: "anémona perfeita, repetida", em cujas areias tocam os pés do poeta, "descalços e leves", como daquela "criança" perseguida, avistada do "navio" ou da margem bombardeada de As palavras interditas.

\subsection{A sempiterna "chama"}

Que seja fogo e suba ao cume das águas seminais e duras, e cante, invada, inunde 
Toda operação poética é, segundo Octavio Paz, uma inversão ou conversão do fluir temporal: "O poema não detém o tempo: o contradiz e o transfigura" (PAZ, 1984, p.11). Donde se desprende a relação paradoxal entre poesia e história ${ }^{178}$, latente em todos os períodos e sociedades, e agravada na modernidade ${ }^{179}$. É nesse caráter de confronto, de certo modo ambíguo, que lemos a exaltação da juventude e do tempo presente em Até amanhã (1951-1956), quarto volume da coletânea. Poesia do sim e canto de esperança, o livro propõe reconstruir o "horizonte bombardeado" e irradiar o presente instantâneo do corpo. Contra o "ódio", a "crueldade", a "tristeza" e a "solidão", os poemas conclamam, no erotismo, um caminho para o reencontro (ou para o "reinventar") de "velhas verdades", proferidas sem receio de pieguismo: "amor", "bondade", "alegria", "juventude", "divino":

\section{Urgentemente}

É urgente o amor.

É urgente um barco no mar.

É urgente destruir certas palavras, ódio, solidão e crueldade, alguns lamentos, muitas espadas.

É urgente inventar alegria, multiplicar os beijos, as searas, é urgente descobrir rosas e rios e manhãs claras.

Cai o silêncio nos ombros e a luz impura, até doer.

É urgente o amor, é urgente permanecer.

(ANDRADE, 1966, p. 139, décimo poema do livro)

\footnotetext{
178 "O poema é um objeto feito de linguagem, dos ritmos, das crenças e das obsessões deste ou daquele poeta, desta ou daquela sociedade. É o produto de uma história e de uma sociedade, mas o seu modo de ser histórico é contraditório. O poema é uma máquina que produz anti-história, ainda que o poeta não tenha essa intenção". Os filhos do barro. Rio de Janeiro: Editora Nova Fronteira, 1984, p. 11.

179 "O sentimento e a consciência da discórdia entre sociedade e poesia converteram-se, a partir do romantismo, no tema central, muitas vezes secreto, de nossa poesia. [...] Desde sua origem, a poesia moderna tem sido uma reação diante, para e contra a modernidade: a Ilustração, a razão crítica, o liberalismo, o positivismo e o marxismo. Daí a ambiguidade de suas relações - quase sempre iniciadas com uma adesão entusiasta, seguida de um brusco rompimento - com os movimentos revolucionários da modernidade, da Revolução francesa à russa" (PAZ, 1984, pp. 11 e 12).
} 
Desde o primeiro livro de Poemas, como temos observado, a poesia eugeniana escreve o corpo, o encontro das palavras com as "mãos", os "olhos", a "boca", o "peito liso e claro" do amado. Neste quarto livro da coletânea, o corpo permanece como manancial de imagens e sentimentos, no entanto, sua "juventude"180 agora surge sob a consciência mais dolorosa da aproximação da velhice. O tema, já conhecido do leitor familiarizado com essa obra ${ }^{181}$, é mais amplo do que a real decrepitude do corpo frente à passagem do tempo. Na leitura que fazemos do conjunto dos poemas do livro, o "envelhecimento" também se estende ao desgaste da própria palavra poética diante das rápidas transformações dos valores e modos de vida na sociedade moderna. Traduz, como admitiria mais particularmente o poema acima, sob o lamento da "luz impura sobre os ombros", inquietações políticas frente ao sentimento geral de saturação e privação da vida, ou diante mesmo da violência do Estado totalitário, como parece sugerir também o poema "Frente a frente", décimo segundo do livro:

\section{Frente a frente}

Nada podeis contra o amor.

Contra a cor da folhagem,

contra a carícia da espuma,

\footnotetext{
${ }^{180}$ Não é a primeira vez, em Poemas, que a "juventude" é convocada como um valor positivo, associado à poética eugeniana. Em As mãos e os frutos, ao lamentar o desgaste do amor e da palavra poética, os versos do poema 34 afirmam: "Passamos pelas coisas sem as ver, / gastos como animais envelhecidos (1966, p. 53). Em Os amantes sem dinheiro, o poema "Elegia", que poderia se dirigir à figura materna, exprime: "Um verso já não é a maravilha, / de um corpo a latejar de plenitude. / Tu quebraste-lhe o ritmo / ao partires um a um/os ramos todos da tua juventude" (1966, p. 77). Em As palavras interditas a "juventude" do corpo amado também é celebrada: "Oh, a carícia da terra, / a juventude suspensa, / a fugitiva voz da água entre o azul / de um prado ou de um corpo estendido!” (1966, p. 113). Contudo, se ela aparece mais esporadicamente nos livros anteriores, neste volume recebe ênfase dentro de um projeto poético revisionista e de resistência, conforme veremos adiante.

${ }^{181}$ É sabido o desgosto que o poeta nutria pela velhice, e a crítica reconhece traços mais visíveis desse sentimento sobretudo a partir de Memória doutro rio, livro de 1978. Conforme salienta António Manuel Ferreira, em "Eugénio de Andrade, figuras de melancolia" (A luz de saturno, figurações da velhice. Aveiro: UA Editora, 2005): “O corpo erótico é sempre juvenil; na erótica eugeniana não há lugar para o corpo envelhecido. Em entrevista a Helena Vaz da Silva, o poeta manifesta, de forma inequívoca, a sua visão repulsiva da velhice, 'uma coisa horrível', entendida como a 'ruína do corpo, o peso sobre os outros, o desamparo.' Esta visão desapiedada é compreensível e inteiramente pertinente numa poesia que reafirma, em múltiplos passos, a centralidade do corpo como lugar da pátria e da casa. [...] Consequentemente, envelhecer significa ir ficando sem pátria e sem casa, porque paralelamente à ruína física também a poesia vai ficando diferente: a decrepitude do desejo torna as palavras ariscas e indomáveis." (2005, p. 55). A deserção de Eros, relacionada, como observa o crítico, ao envelhecimento, contamina esta poesia, profundamente alicerçada no desejo. O tema da velhice, se depreendido como biografema torna-se, por conseguinte, cada vez mais visível na fase posterior da poesia eugeniana. No entanto, se encarada como um problema poético, como também sugere Ferreira, a velhice aparece, associada ao desgaste do amor e da palavra, desde o primeiro livro As mãos e os frutos. Em Até amanhã, encontramos o clamor, quase desesperado, à "juventude", lido como afirmação do corpo e do tempo presente: temas que repercutem no problema da palavra e de sua efetividade histórica.
} 
contra a luz, nada podeis.

Podeis dar-nos a morte,

a mais vil, isso podeis

- e é tão pouco!

(ANDRADE, 1966, p. 141)

Ambos os poemas procuram reverter o fluxo histórico-temporal ao fundarem-se na intensidade do presente instantâneo do corpo e da palavra poética, como indica, por exemplo, o caráter inaugurador do trecho: "É urgente inventar alegria, / multiplicar os beijos, as searas, / é urgente descobrir rosas e rios/ e manhãs claras". Nesse sentido, a escrita eugeniana se posiciona contra o desconhecimento dos sentidos do corpo, tomado apenas como instrumento de trabalho (ou de culto estético plastificado) em nossa sociedade, destinado a um envelhecimento precoce e a uma "morte vill". A alienação do corpo, providenciada também pela moral religiosa conservadora, dominante durante os anos de ditadura em Portugal, contribui, como podemos supor, para o aniquilamento geral do humano, tal como pressentido pelo sujeito moderno. A "juventude" comparece, desse modo, em sua instância crítica, como uma espécie de afronta ao medo, ao desespero, e sobretudo à dúvida, que assolavam o sujeito em As palavras interditas. Afirma-se o erotismo contra a mutilação sistemática do corpo e do homem; a alegria contra o ódio e a tristeza; a juventude contra o conformismo a um mundo caduco; e a palavra como último grito de permanência:

\section{Juventude}

Sim, eu conheço, eu amo ainda esse rumor abrindo, luz molhada, rosa branca! Não, não é solidão, nem frio, nem boca aprisionada. Não é pedra nem espessura. É juventude. Juventude ou claridade. É um azul puríssimo, propagado, isento de peso e crueldade.

(ANDRADE, 1966, p. 129, segundo poema do livro)

Um novo "sim" é dado à palavra, e suas representações, já conhecidas dentro do universo eugeniano, são evocadas, tanto no "barco no mar" do poema "Urgentemente" mais acima quanto no "rumor abrindo", "luz" e "rosa branca" deste poema - signos 
esses que também nos levam, por outro lado, a outras redes de sentidos e associações dentro dessa poesia, seja da relação do sujeito com o amado, seja do tema do passado, da figura materna, etc. Na obra de Eugénio de Andrade, como temos demonstrado, tudo se agrega: para falar de amor, de memória, de experiência, é preciso também falar de poesia. E, acima de tudo, "pensar" a poesia a fim de erguer suas potencialidades estéticas frente à saturação geral da linguagem ou das formas poéticas, tão pressentida e lamentada pelo sujeito eugeniano.

Por outro lado, o poema também rejeita imagens ou ideias obsessivas que percorriam os livros anteriores, como a "pedra", que no poema "Exílio", de As mãos e os frutos, se metamorfoseava em "pássaro" com o esforço do canto. Ou a "solidão", o "frio" e a "boca aprisionada" de As palavras interditas, associados ao desespero e ao agrilhoamento do sujeito, como vimos na análise deste terceiro livro. A "espessura" ou o "peso" são contrabalançados com imagens de leveza, mobilidade e abertura, como "luz", "claridade", "azul puríssimo", "rumor abrindo". ${ }^{182}$

Desse modo, embora se reporte a um repositório imagético conhecido, trazendo à baila velhas representações que o sujeito ora rejeita, ora declara "amar ainda" a despeito do seu desgaste, o poema assinala a procura de novas relações dentro dessa poética, novos "nomes" para sua contínua busca: "juventude", capaz de "gritar" contra o cansaço e o abatimento, despertar o corpo e os sentidos, revivescer a palavra poética, celebrada tanto no "sim" que abre o poema como no "azul puríssimo, propagado" que o encerra, dissipando o cenário de ruínas do livro anterior.

Para compor uma erótica, a poética eugeniana se vale de seu léxico circunscrito, movimentado por entre uma complexa rede metamórfica, cuja inspiração principal é o “corpo" e seus domínios: "terra”, “boca”, "rosto", “mãos”, “dedos”, “sangue”, "água”; em direção ao campo do maravilhoso, da quintessência, da venturosa unidade reconciliada, cujos signos etéreos da "luz", do "fogo", do "voo" e do "anjo" parecem evocar. Dentro dessa constelação de signos, identificamos a "luz" ou a claridade em

\footnotetext{
${ }^{182}$ Uma das características mais marcantes do discurso literário é o fato de ele se impor como diferença em face da tendência geral de homogeneização da cultura e da sociedade. Nesse sentido, não é incomum que o escritor procure imagens de "leveza" para contrapor ao "peso do mundo", conforme esclarece Italo Calvino, que logo descobriu, como escritor, o abismo que havia entre seu estilo ágil, impetuoso e o "pesadume, a inércia, a opacidade do mundo": peso resultante da "intricada rede de constrições públicas e privadas [que] acaba por aprisionar cada existência em suas malhas cada vez mais cerradas". Seis propostas para o próximo milênio. Trad. Ivo Barroso. São Paulo: Companhia das Letras, 1991. Assim, temos que apenas a "vivacidade e a mobilidade da inteligência" escapam à condenação: qualidades aplicadas à composição das obras de arte, como aponta o crítico: "salto ágil e imprevisto" de sobrelevar o peso do mundo (1991, p. 24).
} 
geral (“amanhecer”, "rumor branco", "manhã clara”, "manhã de oiro”, "lume”, "raio de sol", "relâmpago") como signo central do livro - referido também em seu elemento primitivo, como "chama" ou "fogo" 183 -, por promover, conforme veremos ao longo dos poemas, a aspirada reconciliação entre domínios tradicionalmente representados em oposição no Ocidente, como, por exemplo, corpo e alma.

Como ponto de partida da perscruta erótica, o poema de abertura do livro exalta, mais uma vez, a realidade das "mãos":

\section{Coração habitado}

Aqui estão as mãos.

São os mais belos sinais da terra.

Os anjos nascem aqui:

frescos, matinais, quase de orvalho,

de coração alegre e povoado.

Ponho nelas a minha boca, respiro o sangue, o seu rumor branco, aqueço-as por dentro, abandonadas nas minhas, as pequenas mãos do mundo.

Alguns pensam que são as mãos de Deus; - eu sei que são as mãos dum homem, trémulas barcaças onde a água, a tristeza e as quatro estações penetram, indiferentemente.

Não lhes toquem: são amor e bondade. Mais ainda: cheiram a madressilva! São o primeiro homem, a primeira mulher. E amanhece.

(ANDRADE, 1966, p. 127)

${ }^{183}$ A "luz" e suas fulgurações próximas aparecem em quase todos os vinte poemas do livro. Só não estão presentes em dois poemas (embora a cor branca apareça discretamente em um deles), ou seja, dez por cento do total. O "fogo" ou "chama" surge, explicitamente, em quatro poemas: "Metamorfoses da palavra", "Serenata", "Matinal" e "Retrato". A "luz" é uma constante na poesia eugeniana, associada aos princípios definidores de um projeto estético, como observa Carlos Mendes de Sousa: "O que decerto passaria pela constatação de uma aguda consciência da modernidade que esta poética comporta. Na senda de uma (moderna) tradição que faz esplender o poema em si mesmo como entidade autônoma em que, como bem disse Eduardo Lourenço, a 'imediata fulgurância da palavra será perseguida pelo Poeta, com Ostinato rigore, até a última assimilação e habitação do mundo como Palavra"” (SOUSA, 1992, p. 106). Mendes Sousa também reconhece maior ênfase sobre a "luz" em Até amanhã e aproxima este livro do poeta, pela mesma razão, a Branco no branco, publicado em 1984: "O mais marcado traço de união que me faz aproximar os dois livros é essa simbólica vizinhança: de uma simultaneamente outra e mesma luz" (SOUSA, 1992, p. 106). 
Para falar de um coração pleno e "habitado", o poema parte das "mãos", dispostas em uma imagem totalizante que tanto poderia se referir às mãos dos amantes: "Aqueço-as por dentro, abandonadas/ nas minhas, as pequenas mãos do mundo", como poderiam também aludir às próprias mãos do poeta a recolher metaforicamente as "mãos do mundo" no ato criador da escrita. Debaixo delas nascem "anjos de orvalho", "de coração alegre e povoado" e "rumor branco" - expressão que mais uma vez reúne "som" e "luz", lidos como unidades elementares da palavra.

Nesse sentido, são as mãos que narram o decorrer do poema, que só emerge por intermédio de seu ato bondoso e amoroso. Esse é um poema-ato por excelência, pois se movimenta em torno do próprio gesto que o originou - gesto que se multiplica a cada vez que o poema é lido e que inaugura aquela realidade que as palavras abrem, onde habitam "o primeiro homem" e a "primeira mulher". O poema clama por um retorno à plenitude adâmica, em que a linguagem estabelecia o encontro primordial entre o homem e as coisas. Conforme Eduardo Lourenço, o fazer poético de Eugénio de Andrade é "posse do mundo e de si mesmo"; é cantar paradisíaco que devolve ao homem seu próprio lugar, anterior à separação do mundo e de si mesmo provocada pela linguagem. ${ }^{184}$ Eugénio de Andrade renomeia as coisas para instituir o estado puro em que elas nos apareceram pela primeira vez, quer dizer, "instaura o anel mágico da antiga aliança sem palavras entre o homem e as coisas" (LOURENÇO, 1971, p. 40). Assim, as palavras que nascem "debaixo das mãos" são puras como os "anjos" e como o "orvalho", e a alegria e a plenitude que despertam contrastam com o estado do próprio criador, cujas mãos, "trêmulas barcaças" 185 , revelam fragilidade e tristeza quanto à "indiferença" da morte: esta que faz pulsar o tempo a "penetrar as quatro estações" e a envelhecer o corpo. Desse modo, a par da celebração do "dom divino" das mãos, que despertam "anjos", mensageiros dos deuses, há a triste constatação de sua fragilidade diante da vida e da passagem do tempo. Ainda que o poema desperte o milagre do mundo em sua própria criação, há o tom melancólico que subsiste no ato terno de

\footnotetext{
184 “A poesia de Eugénio de Andrade”. 21 ensaios sobre Eugénio de Andrade. Porto: Inova, 1971, p. 34. ${ }^{185}$ Ao referir-se às "mãos", engajadas no ato da escrita, como "trêmulas barcaças", Eugénio de Andrade compara o ato poético ao vaguear hesitante do "barco", figura central do livro anterior. António Manuel Ferreira, por exemplo, diz que "a relação do poeta com sua poesia nunca foi inteiramente pacífica" (FERREIRA, 2005, p. 58); nesse sentido, a figura do barco à deriva, tal como propomos, traduz muito bem esse pensar tortuoso de sua poética, que, mesmo em um livro tão afirmativo quanto Até amanhã, expõe também suas dúvidas e fragilidades.
} 
voltar-se para as próprias mãos, as quais, à primeira vista, parecem "as mãos de Deus", mas logo se revelam humanas, mortais, envelhecidas.

Eugénio de Andrade procura por respostas na relação de transparência entre poesia e mundo, na "pureza" de tema e palavra, na musicalidade e materialidade edênica, alinhando-se àquilo que Lourenço denomina "navegação autônoma no interior da realidade poética concebida e praticada como mundo substancial e subsistente" (1971, p. 52). É para essa realidade autônoma que o poema "Coração habitado" apela, principalmente através do movimento de ascese que o último verso traça: "E amanhece". Há um alargamento final no horizonte imagético do poema, radiado de máxima luminosidade e esperança, cujo efeito é de renascimento para o "dia", instante mais novo e puro.

Ao desdobrar o ato poético, Eugénio de Andrade também procura evidenciar os modos pelos quais a própria linguagem é capaz de promover o encontro com o "maravilhoso", irrompendo novas realidades para além do cansaço habitual e angustiante. Certos signos centrais, como as "mãos", proliferam uma série de imagens díspares que são aproximadas no poema, em que "mãos" se tornam sinais da "terra" e de "anjos", onde correm "sangue" e "rumor branco". Unem-se, desse modo, o concreto e o abstrato, o dizível e o indizível, o imanente e o absoluto, ou o mundo exterior e a subjetividade humana. As imagens modulam-se em apelo para os diversos sentidos: "respiro o sangue", “cheiram a madressilva", "amanhece".

A essa percepção vital e vivência epifânica na poesia, Eduardo Lourenço chamou de "Angelismo", devido, principalmente, ao longo cortejo de anjos e "mensageiros dos deuses" que aparece na poesia portuguesa do século $\mathrm{XX}^{186}$, como neste e em vários outros poemas de Eugénio de Andrade, a evocar a "palavra celebrante" ou o "sim original da existência", concebidos em tempos mais remotos e mais poéticos. Na poesia eugeniana, essa "condição angélica" se manifestaria não só através da figura de "anjos" (recorrente em Até amanhã) e "deuses dançantes", mas

\footnotetext{
186 Para o crítico português, boa parcela desse "metaforismo angélico" descende diretamente de Rilke, poeta bastante lido e traduzido em Portugal a partir da década de 1940. No entanto, é possível inserir o "angelismo" da poesia moderna contemporânea dentro de uma tradição mais ampla, anterior à irrupção de Rilke: "Foi sem dúvida porque a palavra poética contemporânea se concebeu como palavra sem interlocutor que o Anjo como presença interrogante, e a quem se interroga, surgiu no horizonte imagético de várias gerações separadas por gostos e ideias aparentemente inconciliáveis". Em "Angelismo e poesia”. Tempo e poesia. Lisboa: Gradiva, 2003, p. 120.
} 
também em motivos que evocam a inocência da "fonte", da "água”, do "pássaro" e dos elementos primordiais:

[...] Absorção sem resíduo do verbo natural ou transcendente na palavra poética. [...] Toda a poesia dos últimos 25 anos é uma glosa desta visão angélica da Palavra ou da Palavra como Anjo. [...] Nunca se visionara com tanta eficácia o poema como duplo mágico do mundo, sua habitação, tanto como secreto e íntimo pulsar. Às palavras, ou à Palavra que como poema as convoca para existir, o Poeta confere os dons que a Teologia reserva aos anjos, mediadores resplandecentes de um excesso de realidade que contemplada nos destruiria e é nesse poder e na sua encarnação que reside o puro angelismo poético.

(LOURENÇO, 2003, pp. 127 e 129)

A vivência do transcendente reside, dessa maneira, no "excesso de realidade" resplandecente que o poeta entrevê ao romper, na própria linguagem, com os grilhões impostos ao homem. Dessa forma, o ato poético adquire o caráter de "operação vital", ${ }^{187}$ no sentido de resistir à ausência do homem no homem e transcender os limites da vida social e histórica para uma vivência mais abrangente do mundo fenomênico e das capacidades humanas. Assim, apesar do movimento de ascese e abertura da linguagem, "os anjos" permanecem, essencialmente, "sinais da terra": o sagrado se manifesta na própria vida corpórea; as "mãos" não revelam "Deus", mas o verdadeiro homem, em seu esplendor como também em toda a sua fragilidade. ${ }^{188}$

Nessa perspectiva, o "corpo", tanto quanto a palavra, permite o contato com os sentidos, o mover dos desejos e da imaginação, conduzindo o homem a uma vida mais criativa e mais plena de suas possibilidades. No poema "Apenas um corpo"189, quinto

\footnotetext{
187 Expressão de Marcel Raymond. De Baudelaire ao surrealismo. São Paulo: Edusp, 1997, p. 12.

${ }^{188}$ O poema "Quase madrigal", oitavo do livro, afirma, em termos semelhantes, a perspectiva imanentista desta poesia: "Os anjos que prometes são apenas / o rosto triste dos dias desolados. Eu não prometo nada, sou alegria. / Aceito os anjos nos beijos que me dás, / pondo rosas nos teus dedos descuidados. (ANDRADE, 1966, p. 136) Os “anjos” de Eugénio de Andrade não são promessas de um mundo futuro, como na tradição cristã, mas manifestações da vida corpórea. Do mesmo modo, se dá a aparição de "deuses" na sua poesia, conforme explica Pedro Eiras em "O regresso dos deuses - sobre a poesia de Eugénio de Andrade” (Revista Relâmpago. N. 15, Ano VIII, 10/2004): o paraíso na poesia eugeniana é humano. "O poema define o paraíso a partir de um tempo vivido" (2004, p. 91). Os deuses aparecem como configurações da matéria, como "acontecimento de linguagem" e "acontecimentos do mundo natural” (2004, p. 92).

${ }^{189}$ O vocábulo "apenas" percorre inúmeros versos e títulos de poemas da coletânea, como neste "Apenas um corpo", ou em "Apenas um rumor", bem como suas expressões irmãs: "Quase nada", "Talvez nada", "Nem sequer", "Não é nada meu amor", "Foi apenas um dia que passou”, ou em títulos como "Quase madrigal", "Quase nada" e "Quase um haikai". Essas locuções adverbiais de dúvida ou intensidade geralmente ressaltam o caráter de hesitação dessa poesia perante a expressão encontrada, ou perante o material poético potencial, o que revela, como já foi dito, a relação conflituosa entre o poeta e sua poesia. Porém, essas expressões também se imbuem de certa ambiguidade ao apontar, de modo irônico, para a
} 
do livro, o ato erótico poderia ser comparado ao poder demiúrgico da escrita: ambos são divinizados por providenciar ao homem o ímpeto criador e uma visão mais abrangente da realidade.

\section{Apenas um corpo}

Respira. Um corpo horizontal, tangível, respira.

Um corpo nu, divino,

respira, ondula, infatigável.

Amorosamente toco o que resta dos deuses.

As mãos seguem a inclinação

do peito e tremem,

pesadas de desejo.

Um rio interior aguarda.

Aguarda um relâmpago,

um raio de sol,

outro corpo.

Se encosto o ouvido à sua nudez,

uma música sobe,

ergue-se do sangue,

prolonga outra música.

Um novo corpo nasce,

nasce dessa música que não cessa,

desse bosque rumoroso de luz,

debaixo do meu corpo desvelado.

(ANDRADE, 1966, p. 133)

A experiência do ato amoroso permite o nascimento de uma "música" a prolongar "outra música" como se outro "corpo" nascesse, o que poderia sugerir não só o nascimento do poema (“outra música”, "outro corpo”), mas também o gesto genesíaco que se dá a partir de toda movimentação da matéria e perpetuação da energia vital. Ao mimetizar a mobilidade da natureza, a metamorfose poética procura conduzir-nos à vivência da permanência e do infinito. Dessa maneira, a palavra poética, em constante transformação e abertura, capta, na brevidade das substâncias, a própria "eternidade", ou seja, o perpétuo refazer-se do "imediato", "substância impossível" tanto para os

própria escassez que se transforma em poesia: um aparentemente pouco que é muito, como no título "Os amantes sem dinheiro", em que a plenitude é alcançada na simplicidade dos elementos da natureza e do amor, expressos também por uma linguagem cada vez mais "pura" e despida. Este parece ser o caso de "Apenas um corpo": aparentemente desprovido de sutilezas, mas que, como demonstra o poema, contém resquícios do que outrora se chamou de presença divina. 
mortais quanto para os imortais, como dizia Hölderlin ${ }^{190}$, e por isso identificada como "puro divino", como aquilo que está "por detrás dos deuses", sendo nada mais do que a “intensa sensação de estar vivo". O encontro com "Deus" dá-se, portanto, na imanência da vida, no corpo, no homem, na terra e no ato de criação. Tanto neste quanto no poema "Coração habitado", há certa inversão, ou imersão "do divino no natural e do natural no divino", para utilizar a expressão de Lourenço.

O impulso vital do ato erótico, relacionado aos elementos próximos do "fogo", como "raio de sol", "relâmpago" e "luz" (que, na simbologia tradicional, também estão associados ao sagrado, à presença divina), acarreta um movimento de abertura marcadamente ascensional ao final do poema ("uma música sobe, ergue-se do sangue", "bosque rumoroso de luz"), em que os elementos etéreos do som e da luz ficam a prolongar a comunicação entre domínios tradicionalmente separados pela excessiva racionalização de nossa cultura ocidental. Assim, o "corpo" revela-se ambíguo como o "fogo": é matéria e ardor, tanto quanto é etéreo, dinâmico, sublime. Sua energia solar pode abarcar, por um lado, o campo dos instintos e das paixões, e por outro, as sutilezas do intelecto. ${ }^{191}$ Dentro da simbologia tradicional, o "fogo" é um signo contraditório e por isso também totalizante: remete a esferas psíquicas radicalmente opostas pela tradição greco-cristã, como razão e revelação, ou razão e inspiração ${ }^{192}$. Evoca o poder de criação e transformação da natureza, mas também a força destruidora de desencadeamento dos elementos. É símbolo das paixões devoradoras, mas pode também

\footnotetext{
${ }^{190}$ Citado por Roberto Calasso. A literatura e os deuses. São Paulo: Companhia das Letras, 2004, p. 34.

191 Fragmentos de uma poética do fogo. São Paulo: Editora Brasiliense, 1990, p. 97. Gaston Bachelard explica, entre outras, a acepção do "fogo" sob o signo de Prometeu, herói grego que roubou o fogo dos deuses para oferecer aos homens e por isso foi submetido ao suplício de ter o fígado diariamente devorado por uma águia. Conforme o filósofo, o "fogo" proteico vincula-se ao trabalho intelectual do espírito, à aquisição de conhecimentos e à "aceleração do saber", em que nos elevamos acima de nós mesmos e acima da natureza comum. Por isso, o "fogo" associa-se aí também à desobediência construtiva e ao sofrimento acarretado por um espírito dado à especulação filosófica. Assim, o fogo prometeico surge em suas mais diversas faces na história da cultura ocidental como racionalidade crítica que necessariamente destrói o próprio pensamento anterior, como união da rebelião, esclarecimento, criatividade. O "fogo" na poesia eugeniana também recupera essa acepção, como veremos na análise do próximo poema. Em "Apenas um corpo", ele associa-se, sob o signo de "relâmpago", ao campo dos instintos, bem como à matéria mais sutil, ligada à música, aos sentidos e ao intelecto.

192 Octavio Paz explica essa contradição basilar do pensamento ocidental: "A dupla herança do monoteísmo judaico e da filosofia pagã constitui a dicotomia cristã. A ideia grega do ser - em qualquer de suas versões, [...] - é irredutível à ideia judaica de um Deus único, pessoal e criador do universo. Esta oposição foi o tema central da filosofia cristã desde os Padres da Igreja. [...] A modernidade é a consequência dessa contradição, dessa disputa entre razão e revelação [...]. A modernidade se inicia quando a consciência da oposição entre Deus e o Ser, razão e revelação, se mostra de fato insolúvel" (PAZ, 1984, pp. 45 - 46).
} 
significar pureza e depuração. ${ }^{193}$ Conforme Gaston Bachelard, em A chama de uma vela, a linguagem do fogo nunca é dual, pois não traduz simplesmente o material em espiritual e vice-versa. Antes instaura, em cada uma de suas imagens, a vivência da unidade: a "chama" testemunha um mundo em ignição, dirigido para a transformação:

O sonhador vê nela seu próprio ser e seu próprio vir a ser. Na chama o espaço mexe, o tempo se agita. Tudo treme quando a luz treme. A mutação do fogo não é a mais dramática e a mais viva das mutações? $\mathrm{O}$ mundo anda depressa se for imaginado em fogo. Assim o filósofo pode sonhar tudo - violência e paz - quando sonha com o mundo diante da vela.

(BACHELARD, 1989, pp. 37-38)

No quadro da poética eugeniana, a "chama" é essencialmente criadora, embora não deixe também de recuperar a vasta memória das contradições cósmicas do "fogo". Como temos visto desde o primeiro livro de Poemas, a "luz", ma4, máxima transubstanciação do fogo, aproxima-se do poder genesíaco da palavra. Figura o excesso de realidade e é metáfora da transformação de toda expressão poética. Em Até amanhã, há uma verdadeira cosmogonia da luz: desde seu elemento mais primitivo até a energia transubstanciada nas diversas manifestações de claridade. Em todas as suas etapas, a luz participa no trabalho de abertura da linguagem ${ }^{195}$. Em diversos momentos, como no sexto e no décimo terceiro poemas do livro, que transcrevemos abaixo, compõe-se uma verdadeira "poética do fogo":

\section{Metamorfoses da palavra}

A palavra nasceu:

nos lábios cintila.

\footnotetext{
193 "The meanings of fire are not manifold but sometimes ambiguous. It is warm but it also burns; it can illuminate but also dazzle and blind the eye. It brings life and death, is found on earth, in heaven and in hell." ("Os sentidos do fogo não são múltiplos, mas, às vezes, ambíguos. O fogo aquece, mas também queima; pode iluminar, mas também ofusca e cega. Traz vida e morte; é encontrado tanto na terra e no céu, quanto no inferno." Tradução nossa). A dictionary of literary symbols. Michael Farber. Cambridge: University Press, 1999, pp. 72 e 74.

${ }^{194}$ Sobre a "luz" em relação à "chama", Bachelard discorre: "Para um pensador da chama [...], os fatos devem abrir um horizonte de valores. O valor a conquistar aqui é a luz. A luz é então uma supervalorização do fogo. [...] A iluminação é realmente uma conquista" (BACHELARD, 1989, pp. 3334).

195 Desde a literatura romântica, a própria arte passou a ocupar o lugar do poder divino, e o signo da "chama" deslocou alguns de seus significados mais tradicionais, passando a evocar, além da aspiração religiosa, a aspiração artística e erótica, e a vontade de transformação do eu lírico. Cf. Metzler Lexikon literarischer symbole. Org. Günter Butzer e Joachim Jacob. Stuttgart: J.B. Metzler, 2008, pp. 101 a 103.
} 
Carícia ou aroma,

mal poisa nos dedos.

De ramo em ramo voa,

na luz se derrama.

A morte não existe:

Tudo é canto ou chama.

(ANDRADE, 1966, p. 134)

Breve, fugidia, a palavra eugeniana nasce do corpo, dos "lábios", dos "dedos", para esvaecer-se em "fogo", "chama" ou "luz que se derrama", traçando novo movimento de ascese, a recuperar, de certa maneira, a vivência do absoluto - ainda que revertida para uma perspectiva imanentista. Assim, desde sua primeira manifestação, a palavra é luminosa e se expande gradualmente, envolvendo os sentidos, como o tato (“carícia”), o paladar ("lábios”), o olfato (“aroma”) e a visão (“cintilar”), em comunhão com os elementos. No cume, o "canto" final da palavra ao infinito é descrito em termos de "chama": fusão metafísica do instante ampliado, linguagem absoluta, ascensão do ser: "Parece que um tempo cósmico vem aqui ampliar o tempo subalterno, esse tempo que encadeia e não produz. O poema eleva-se a um nível de acontecimento do universo para conhecer o instante de um clarão" (BACHELARD, 1990, p. 57).

Segundo Bachelard, toda "poética do fogo" alimenta a fantasia da altura ${ }^{196}$, pois é sempre no alto que o "fogo" se torna "luz": espaço-instante em que pressentimos a comunicação entre o real e o irreal, ser e não-ser, vida e morte:

[...] A chama é precária e vacilante. Essa luz, um sopro a aniquila; uma faísca a reacende. A chama é nascimento e morte fáceis. Vida e morte aqui podem ser justapostos. [...] Os jogos de pensamento dos filósofos levando suas dialéticas do ser e do nada num tom de simples lógica tornam-se, diante da luz que nasce e que morre, dramaticamente concretos.

\footnotetext{
196 "Entre as fantasias que nos aliviam, bem eficazes e simples são as da altura. Todos os objetos retos e em pé designam um zênite. Uma forma reta e de pé se lança e nos leva em sua verticalidade. Conquistar um pico real continua sendo uma proeza esportiva. O sonho vai mais alto, ele nos leva para além da verticalidade. [...] As fantasias da altura alimentam nosso instinto de verticalidade, instinto recalcado pelas obrigações da vida comum, da vida vulgarmente horizontal. A fantasia verticalizante é a mais libertadora das fantasias. [...] Os sonhos com o acima fazem esquecer, suprimir os do embaixo. Vivendo no zênite do objeto em pé, acumulando as fantasias de verticalidade, conhecemos uma transcendência do ser. As imagens da verticalidade fazem-no entrar no reino dos valores. Comungar por meio da imaginação com a verticalidade de um objeto reto é receber o benefício de forças ascensionais, é participar do fogo escondido que habita as formas belas, as formas seguras de sua verticalidade" (BACHELARD, 1989, pp. 59 e 60$)$.
} 
A poesia ultrapassa a dialética entre vida e morte, cinde os contrários, afirma uma eternidade que vive no instante breve da chama volante. É, pois, na eternidade do "fogo" que a poética eugeniana encontra relação com a "juventude": instante da palavra que anula a passagem do tempo e dissolve a sensação de envelhecimento, ainda que somente em movimento, como ser em combustão: “[Para o sonhador] a chama é o símbolo de um ser absorvido por sua transformação. A chama é um ser-em-mutação, uma mutação-em-ser" (BACHELARD, 1989, p. 41). ${ }^{197}$

Nesse mesmo contexto, o poema "Matinal", tornado epígrafe para a nossa análise deste quarto volume, também ergue o canto, a perseguir, na imagem renovadora do "fogo", a purificação e a "juventude":

\section{Matinal \\ Que seja fogo e suba ao cume das águas seminais e duras, e cante, invada, inunde - juventude, juventude!}

(ANDRADE, 1966, p. 142)

A estrofe final de "Urgentemente", primeiro poema transcrito acima, lamentava uma certa "luz impura", imbuída de dor e silêncio: "Cai o silêncio nos ombros e a luz/ impura, até doer. / É urgente o amor, é urgente/ permanecer”. Em direção contrária à queda dessa "luz impura" sobre os ombros, associada ao peso, ao cansaço habitual, e à sensação de morte, o eu lírico mobiliza, mais uma vez em "Matinal", a força ascencional da palavra poética.

O poder renovador do "fogo" pode despertar os saberes adormecidos do corpo, reanimar os sentidos para o reencontro do homem com o mundo. Até mesmo no alto do cume, o "fogo" não se desprende dos elementos terrenos: é "água" a "cantar" e a "inundar", e essa reconciliação da palavra poética recebe aqui o nome de "juventude", assim como na primeira estrofe do poema "Serenata", sétimo do livro, ela é chamada de "bondade": "Venho ao teu encontro a procurar / bondade, um céu de camponeses, / altas

${ }^{197}$ Conforme citado anteriormente, estamos inserindo em nossa análise reflexões de Gaston Bachelard acerca do fogo presentes em duas obras: Fragmentos de uma poética do fogo, editada em 1990, e A chama de uma vela, editada em 1989. 
árvores onde o sol e a chuva / adormecem na mesma folha [...]" (ANDRADE, 1966, p. $135)$.

No cume, "fogo" e "água", "sol" e "chuva" reconciliam-se no corpo de uma "folha". Todo o tempo e as estações do ano estão contidos no instante da "folha", breve como o "fogo", instável como o "pássaro" sobre a árvore, ou nas mãos dos amantes, mutável como o "fruto". Os signos constantes da poesia eugeniana transferem-se de poema a poema para despertar, a cada vez, a sensação de novo instante. Neste quarto livro da coletânea, participam de um projeto poético essencialmente revisionista. É nesse sentido que evocamos o tom de revisitação de "Até amanhã", terceiro poema do livro e talvez o principal, por levar o mesmo título:

\author{
Até amanhã \\ Sei agora como nasceu a alegria, \\ como nasce o vento entre barcos de papel, \\ como nasce a água ou o amor \\ quando a juventude não é uma lágrima. \\ É primeiro só um rumor de espuma \\ à roda do corpo que desperta, \\ sílaba espessa, beijo acumulado, \\ amanhecer de pássaros no sangue. \\ É repentinamente um grito, \\ um grito apertado nos dentes, \\ galopes de cavalos num horizonte \\ onde o mar é diurno e sem palavras. \\ Falei de tudo quanto amei. \\ De coisas que te dou \\ para que tu as ame comigo: \\ a juventude, o vento e as areias ... \\ (ANDRADE, 1966, p. 130)
}

Sustido por estrofes mais ou menos regulares, pelo contraste entre sílabas tônicas e átonas, e pela repetição de alguns sons, o ritmo de "Até amanhã" - a sugerir, talvez, proximidade semântica com o título do poema - tende à dilatação. Na primeira estrofe, a repetição assonante da vogal aberta "a" propaga a melodia entre "agora", "nassceu”, “a a alegria”, “nassce”, "bạrco", "pappel”, “água”, “amor”, "lágrima”, cujo efeito sonoro vem concordar com o sentido de apresentação ou de inauguração que a repetição do verbo "nascer" invoca. Ou seja, além da noção de abertura e entrega que a vogal "a" 
propõe ${ }^{198}$, sua repetição, ressaltada através do contraste com vogais mais fechadas ou átonas, resulta no tom exultante da estrofe, como um grito ou exclamação de júbilo a se propagar, distribuindo-se também pelas sílabas alongadas ou simetricamente acentuadas tanto no interior como no final de cada verso: "nasceu-alegria", "vento-papel”, "águaamor", "juventude-lágrima". Desse modo, a vogal "a" na primeira estrofe marca a entrada e a aparição da palavra poética: o poema dá-se a ver, revela-se, oferece seu espaço ampliado. No som largo da vogal cabem todos os gestos de entrega e de acolhimento. A palavra inaugura, afirma, abre-se, presentifica.

Como manifestação reflexiva, o poema põe em evidência as origens e as motivações da palavra poética, e relata, por meio de expressões narrativas, como "primeiro" e "repentinamente", seu processo imanente, fazendo coincidir amor e poesia, corpo e palavra, criação e crítica, desde o passado dessa poética, como em "Falei de tudo quanto amei”, até as possibilidades do futuro, conforme expresso no título. Nesse sentido, as anáforas "como nasce", na primeira estrofe, e "É", na segunda e na terceira, funcionam como tentativas definidoras de uma poética que se pretende essencialmente revisionista neste poema, a enumerar as etapas de seu percurso, desde suas principais forças-motoras, como a potência do desejo, evocada em imagens de intensa carga sexual: "vento", “água”, “espuma à roda do corpo", "beijo", "golpes de cavalos”, até as aspirações de transcendência da palavra e do ser: "amanhecer", "pássaros", "horizonte", "mar diurno".

As imagens vão conquistando movimento, e a essa dinâmica subjaz a ideia de poesia como instauração de uma nova realidade ${ }^{199}$, autônoma e vigorosa, como

\footnotetext{
${ }^{198}$ No capítulo "O som no signo" (O ser e o tempo da poesia. São Paulo: Editora Cultrix, 1977, pp. 40 a 44), Alfredo Bosi explica que embora a "substância da expressão" possa ser hoje considerada arbitrária, cada signo traz marcas ou vestígios da relação outrora mais profunda entre "o corpo do homem que fala e o mundo de que fala". O exercício poético, portanto, trabalharia esse caráter expressivo dos sons, já que sua atividade não se dissociou da experiência do corpo e dos afetos. Assim, Bosi utiliza os experimentos e a teoria do linguista Edward Sapir para justificar a sensação de amplitude que a vogal "a" nos evoca: "No caso de /a/, a língua se abaixa de maneira considerável, em comparação com o /i/, e também se retrai. Em outros termos, a coluna do ar em vibração passa agora por uma câmera de ressonância muito mais larga. Esta explicação cinestésica é tão simples quanto a acústica, e na realidade quer dizer apenas que um gesto com amplitude espacial simboliza a referência do 'grande' em melhores condições do que um gesto espacialmente restrito".

199 Octavio Paz rastreia, desde os primórdios do que se costumou denominar "idade moderna", o desenvolvimento histórico de uma das ideias mais basilares na literatura moderna, tão cara ao nosso entendimento da poesia eugeniana (sobretudo da coletânea de Poemas), como produção poética das décadas de 1940 e 1950 em Portugal: a questão da "autonomia" da arte: “[...] Os valores artísticos se separaram dos valores religiosos. A literatura conquistou sua autonomia: o poético, o artístico e o belo converteram-se em valores próprios e sem referência a outros valores. A autonomia dos valores artísticos levou à concepção da arte como objeto e esta concepção, por sua vez, conduziu a uma dupla invenção: o
} 
sugerem o "vento" a nascer entre "barcos de papel"200 e a "sílaba espessa" a se formar entre o "rumor da espuma" e o "corpo" que desperta. "Barco" e "rumor", assim como "pássaros" no final da segunda estrofe, são signos reflexivos, tal como temos proposto. Todos participam do movimento que se escreve ao longo do poema, no início mais lento: "vento", "água”, "espuma”, mas que logo se torna mais rápido e mais intenso, até o disparo fulminante (tanto sonoro quanto imagético) da terceira estrofe. A aliteração das consoantes contínuas " $r$ " e "s" contribui, desde a primeira estrofe, para a dilatação gradual do ritmo, mimetizando o "rumor" inicial da palavra em formação. Ou seja, aponta para uma dada movimentação sonora do encontro das substâncias, evocando a ideia de fermentação e de fervor crescente: "sílaba espessa", "amanhecer de pássaros no sangue"; até a disparada de "grito", "galope de cavalo", "horizonte", em que as consoantes "g" e "l”, assim como a sílaba alongada de "horizonte", dão fluidez ao andamento do ritmo, a desaguar na imagem final "mar sem palavras".

Ao mapear o corpo como espaço de origem, através de "espuma", "beijo", "sangue" e "dente", o poema percorre a trajetória expansiva do processo poético, desde a ligação com a matéria ("sílaba espessa") e o andamento do discurso ("galopes de cavalo"), aliado ao impulso do desejo, até a rarefação da palavra e a expansão do ser ("amanhecer de pássaros", "horizonte", "mar diurno").

Como ondas que se formam lentamente e desmoronam no refluxo silencioso, o movimento que deságua no "mar diurno e sem palavras" é cíclico: figura o retorno ao silêncio anterior e posterior ao "grito". O "mar", assim como o "vento" e as "areias", recupera aquela imagem nostálgica de As palavras interditas: "Na areia branca, onde o tempo começa..."201 (ANDRADE, 1966, p. 98). O debruçar-se sobre o instante

museu e a crítica de arte. No campo da literatura, a modernidade se expressou como culto ao 'objeto' literário: poema, romance, drama. A tendência iniciou-se na Renascença e acentuou-se no século XVII, mas apenas na idade moderna os poetas se aperceberam da natureza vertiginosa e contraditória desta ideia: escrever um poema é construir uma realidade à parte e autossuficiente. Introduz-se assim a noção da crítica 'dentro' da criação poética” (PAZ, 1984, p. 53).

200 A imagem do "vento" entre "barcos de papel" é sugestiva. Poderia remeter à realidade autônoma e arrebatadora que o poeta consegue fabricar na aparente fragilidade do "papel" em que escreve. Mas também parece comparar a atividade do poeta a brincadeiras infantis, em que a fantasia é capaz de criar mares, tempestades e aventuras a partir de simples barcos de papel em poças d'água ou riachos.

${ }^{201}$ Com seu vaivém incerto, o "mar" é uma constante nesta poesia, conforme vimos na análise de $A s$ palavras interditas. Figura todo o princípio, como também se oferece como silêncio ulterior ao canto. Em "Na orla do mar", décimo quarto de Até amanhã, o poema se escreve na "orla", ao encontro do "rumor" do vento. A palavra nascida reconcilia "corpo" e "alma": "Na orla do mar, / no rumor do vento, / onde esteve a linha / pura do teu rosto / ou só pensamento /- e mora, secreto, / intenso, solar, / todo o meu desejo - / aí vou colher / a rosa e a palma. / Onde a pedra é flor, / onde o corpo é alma" (ANDRADE, 1966, p. 143). João de Mancelos inseriu esse poema de Eugénio de Andrade em seu ensaio comparativo 
absoluto $^{202}$ é simultaneamente um retorno às origens: "Falei de tudo quanto amei", e vir a ser sempre contínuo da palavra amorosa: "para que tu as ames comigo", reavivada a cada leitura, sempre "jovem" e "pura”. É tanto uma imagem instantânea quanto movimento a se estender no tempo.

O último verso lança palavras expectantes: na intersecção entre autor e leitor, elas buscam realizar-se como consciência coletiva e como participação histórica. $\mathrm{O}$ futuro depende de quem canta e de quem lê. A palavra-advento de "Até amanhã" oferece o primeiro impulso: golpe de "pássaros", "galopar de cavalos”, “amanhecer".

De modo implícito ou explícito, o poema moderno é crítico de si mesmo: a um só gesto se escreve e examina; evidencia sua condição, liberta do jugo da filosofia, da religião e da mitologia:

Diversamente das sagradas escrituras, a escritura poética é a revelação de si que o homem faz a si. Dessa circunstância procede o fato de a poesia moderna ser também teoria da poesia. Movido pela necessidade de fundar sua atividade em princípios que a filosofia lhe recusa e que a teologia só lhe concede em parte, o poeta desdobra-se em crítico.

(PAZ, 1982, p. 285)

Segundo explica o escritor mexicano, ao ruir a antiga imagem do mundo, em que o "ser" e as "essências" eram explicadas e interpretadas como algo dado, o homem moderno percebeu-se, pela primeira vez, como "possibilidade". Atentou-se para a natureza móvel do "ser": não mais algo dado, mas algo que se cria e se constrói a todo instante. Nesse contexto, o poema moderno, mesmo quando expõe temas e situações variados, nunca mais se desviou de seu propósito de revelar ao homem sua nova condição: "A revelação de nossa condição é igualmente criação de nós mesmos [...]. Nossa condição original é essencialmente algo que está sempre se fazendo a si mesmo" (PAZ, 1982, p. 191).

Do mesmo modo, no emblemático "Até amanhã”, ainda que o sujeito se debruce liricamente sobre as memórias de um tempo de "juventude", o poema procura, a um só

"O avesso da alma: a dignificação do corpo em Eugénio de Andrade e em Walt Whitman", para demonstrar a procura pela unidade e reconciliação do corpo com o espírito presente na obra de Eugénio de Andrade, leitor de Walt Whitman: "À maneira de Whitman e dos transcendentalistas, também Eugénio rejeita o dualismo e defende a necessidade de compreender a pessoa como um ser holístico" (2009, p. 63). ${ }^{202}$ Note-se que o primeiro som marcado é o da vogal aberta de "agora", a abrir o poema. 
tempo, refazer-se como nova possibilidade. O sujeito espera poder reencontrar na linguagem a "juventude" que já se perdeu no curso do tempo histórico. O poema reverte o rumo, tenta esvaziar os espaços saturados e compor uma nova imagem onde o homem possa vivenciar o livre mover do desejo e da imaginação: fluxo do ser em perpétua construção. "Até amanhã" exalta e oferece os espaços retrocedidos da imagem para que nela o homem possa habitar novamente e inventar um novo futuro.

Em "Signos em rotação", Octavio Paz explica que o grande problema da poesia moderna ${ }^{203}$ é duplo: "poetizar a vida social, e socializar a palavra poética". Ou seja, transformar a sociedade em comunidade criadora, em "poema vivo", e o poema em vida social, em "imagem encarnada" (PAZ, 1982, p. 310): "O poeta não se limita a descobrir o presente, desperta o futuro, conduz o presente ao encontro do que vem" ${ }^{\text {204 }}$. Assim, diante da perda da harmonia cósmica, em que se deslocaram o centro do mundo e Deus, a vontade humana desponta como força-motora da existência e do mundo. E subjugada a ela surge a técnica: "vocabulário universal", como define Paz, composto de signos ativos que procuram interferir e moldar o mundo, não mais visto como figura, mas como algo mais ou menos maleável à vontade humana. Os signos da técnica constituem-se, portanto, como um "repertório de significados temporários e variáveis", sempre em movimento, em direção à realidade inexplorada:

A técnica liberta a imaginação de toda mitologia e coloca-a frente ao desconhecido. Faz com que ela se defronte consigo mesma e, diante da ausência de toda imagem de mundo, leva-a a se configurar. Essa configuração é o poema. Fixado no informe, tal como os signos da técnica, e como eles em busca de um significado incessantemente elusivo, o poema é um espaço vazio mas carregado de iminência. Ainda não é a presença: é um conjunto de signos que procuram seu significado e que não significam outra coisa além de ser procura.

(PAZ, 1982, p. 322)

\footnotetext{
203 Em "Sinos em rotação", texto escrito na década de 1950, Octavio Paz define a poesia moderna nos seguintes termos: "A poesia moderna, como prosódia e escritura, inicia-se com o verso livre e o poema em prosa. Un coup de dés [de Mallarmé] encerra esse período e abre outro, que mal começamos a explorar" (PAZ, 1984, p. 360).

${ }^{204}$ Sobre o veio utópico da poesia moderna, Octavio Paz discorre: "Nascidos quase ao mesmo tempo, o pensamento poético moderno e o movimento revolucionário se encontram, ao fím de século e meio de querelas e alianças efêmeras, diante da mesma paisagem: um espaço entulhado de objetos, mas desabitado de futuro" (PAZ, 1982, p. 314). Porém, como enfatiza o crítico, a aliança entre a poesia moderna e o movimento revolucionário nem sempre se manteve firme: "A gesta da poesia ocidental, desde o Romantismo alemão, foi a de suas rupturas com o movimento revolucionário" (PAZ, 1982, p. 311).
} 
Como composição representativa desse novo modo de ser poético, Paz cita $U n$ coup de dês, de Mallarmé, escrito em 1897, que, como crítica, demonstrava que o projeto idealista de fazer do poema o duplo do universo tornara-se absurdo. No entanto, segundo o escritor mexicano, ao conter sua própria negação e dela fazer seu ponto de partida, o poema acabou por se resolver como única possibilidade, mesmo que momentânea, de dizer o absoluto: “A impossibilidade de escrever um poema absoluto em condições também absolutas, [...] graças à crítica, à negação, converte-se na possibilidade, agora e aqui, de escrever um poema aberto em direção ao infinito" (PAZ, 1982, p. 332). O poema define-se como uma "conta em formação", uma "constelação errante": "um punhado de signos que se desenham, se desfazem e voltam a desenhar" (PAZ, 1982, p. 334). Desse modo, o legado de Mallarmé é uma "forma": a própria forma da possibilidade, o "agora em perpétua rotação". Como "mito da forma", o ato poético torna-se uma cerimônia, ou a dramatização de uma nova consciência:

[...] Consciência de ser um equilíbrio instável flutuando em pleno infinito, um acidente entre as inumeráveis possibilidades de energia. Escritura num espaço cambiante, palavra no ar ou na página, cerimônia: o poema é um conjunto de signos que buscam um significado.

(PAZ, 1982, p. 345)

Também a poesia de Eugénio de Andrade se escreve na rotação dos signos, conforme vimos desde o primeiro livro de Poemas, na perpétua metamorfose dos elementos, no duplo movimento de separação e reunião, no "pegar e largar" 205 de cada signo.

Não obstante as diferenças, é possível estabelecer a relação entre a herança de Mallarmé e a poesia eugeniana, como fez também Rosa Maria Martelo, em Vidro do mesmo vidro ${ }^{206}$, que apontou em Eugénio de Andrade, entre outros poetas de sua geração, como Sophia de Mello Breyner Andresen, Jorge de Sena e Carlos de Oliveira, referência determinante para os autores portugueses da década de 1960, ao antecipar a

${ }^{205}$ Tradução e uso livres do conceito de leixa pren ("deixa-prende" ou "larga e retoma"): recurso formal utilizado nas cantigas galego-portuguesas (muito comparado aos movimentos da dança), em que o poeta iniciava a última estrofe reproduzindo o último verso da estrofe anterior, segundo Segismundo Spina. $A$ lírica trovadoresca. São Paulo: Edusp, 1996, p. 388. Eugénio de Andrade também parece utilizar tal recurso na "rotação dos signos": "larga e retoma" os signos, constantemente.

${ }^{206}$ MARTELO, Rosa Maria. Vidro do mesmo vidro. Porto: Campo das Letras, 2007, pp. 11 a 51. 
vontade de reatar vínculos com a linhagem "textualista" 207 das poéticas do fím do século XIX e início do XX, como as do simbolismo - em especial alinhamento com a poesia de Mallarmé -, do modernismo e das vanguardas. Assim, de acordo com Martelo, a poesia eugeniana procurou dar continuidade aos conseguimentos estéticos das primeiras vanguardas, em busca de uma linguagem "mais livre e criativa", que "significava a possibilidade de conquistar também uma experiência mais livre no plano da construção da subjectividade e no plano do conhecimento do mundo" (MARTELO, 2007, p. 13). Dessa maneira, já se faz possível detectar em seus poemas a reabilitação de certos procedimentos, levados a efeito de modo ainda mais radical pela Poesia de 61, em que se privilegiam a interioridade da palavra, como a exploração da metáfora e do símbolo, o entrechoque de imagens, o "adensamento do significante" etc. ${ }^{208} \mathrm{Em}$ estratégia de resistência, essa tendência tentaria desestabilizar os poderes instituídos e as visões de mundo já cristalizadas na própria linguagem, afirmando a autonomia da obra e da palavra como capazes de apresentar ao homem moderno uma realidade alternativa à vivência de perda e fragmentação, fazendo "coincidir a poesia e o poema" e promovendo a "completa integração da experiência da poesia no espaço do poema, [e] a identificação do poético com a experiência da língua e da textualidade" (MARTELO, 2007, p. 37). Eugénio de Andrade pertenceria, portanto, a uma certa tradição "mais afirmativa" na poesia portuguesa, que procura instaurar aquilo que a autora denomina "condição ontológica do texto", em que a própria linguagem seria capaz de restituir e "presentificar" a unidade já perdida para o homem moderno. ${ }^{209}$

\footnotetext{
207 "De certa forma, o que assim se manifestava era uma profunda consciencialização de que a poesia 'só tem sentido se a máquina de expressão preceder e arrastar os conteúdos', para usar uma expressão deleuziana que dialoga de forma extremamente produtiva com a relação, que então se estabelece, entre o pensamento estruturalista, a redescoberta do formalismo russo e a revisitação das poéticas simbolista e modernista" (MARTELO, 2007, p. 12). Importante lembrar que essa religação é realizada em "condição de devir", como explica a autora, não sendo uma "figura de repetição, embora desenhe uma continuidade" (MARTELO, 2007, p. 17).

${ }^{208}$ Ao oferecer-se como espaço de experimentação, essa "tendência mais textualista" colaborava na invenção de "uma língua outra", que, segundo Martelo, pretendia desequilibrar o sistema homogêneo da linguagem comum e romper com a relação referencial entre palavra e mundo. Porém, embora recuse mecanismos referenciais, ela não oferece, de maneira alguma, uma linguagem intransitiva, fechada em si, pois, se desde Baudelaire, "o real se tornou problemático", como demonstra a autora, é natural que a poesia manifestasse desconfiança ante os efeitos de realismo e tentasse se articular com essa "profunda experiência de crise", buscando novos modos de expressão, mas sem que isso significasse fuga ou afastamento da realidade.

${ }^{209}$ Rosa Maria Martelo procura descrever, em termos de "deslocamentos" e "tensões", os diálogos estabelecidos entre as poéticas da segunda metade do século XX em Portugal e a tradição do modernismo. A autora rejeita o termo "ruptura", comumente utilizado para caracterizar certas tendências da poesia dos anos 60, e aponta continuidades, fundamentadas, por sua vez, na árvore genealógica que Eduardo Lourenço traça em Os filhos de Álvaros de Campos: "Cesário, Pessanha, Sá-Carneiro, Pessoa são quatro
} 
Além das características apontadas por Martelo, também identificamos, na poesia eugeniana, a constante transição entre os signos, ou o movimento de "rotação" assinalado por Paz, que se inaugura na poesia moderna a partir de Mallarmé. No caminho em contínuo fazer-se e desfazer-se, sua poesia investiga todos os princípios e se desdobra a cada exame. Nesse percurso, nada é permanente: sua arte poética vai se definindo no movimento ondulatório dos signos, no ciclo aberto do "fruto", no expandir da "ave", no flutuar do "barco", na frágil ascensão do "fogo", etc. A permuta entre os signos formula uma "poética do instante": em cada recomeço procura-se a plenitude da palavra, mesmo que na própria instabilidade dos elementos.

No entanto, é esse mesmo ímpeto de mudança que constitui, por sua vez, a fonte de angústia e de frustração que encontramos repetidamente expressos no decorrer dos poemas eugenianos. Ainda que estruturalmente se fundamente na mobilidade entre os signos, sua poesia lamenta a mudança, a constante flutuação do desejo, o desgaste da palavra, as relações instáveis. A mudança também é fonte de inquietação para o sujeito moderno: desencadeia a sensação de esvaziamento e dissolução. O excesso de possibilidades sempre renovadas de escolha acaba condenando o homem à decrepitude do desejo e à estagnação. O mundo, a cidade, os valores, os bens de consumo, a vontade, as relações humanas ficam a envelhecer diante da monotonia da mudança. Walter Benjamin denominou o tempo entediante da mercadoria e da produção em massa de "eterno retorno do mesmo": descompasso entre o desenvolvimento da técnica e a ordem social que não acompanha as transformações. $\mathrm{O}$ indivíduo é constantemente acometido pelo cansaço da procura pela "novidade", que tão logo encontrada, torna-se velha e desgastada. $^{210}$

figuras essenciais da construção de uma poesia de Modernidade em Portugal; Sophia, Cesariny, Eugénio, e depois Ramos Rosa, alguns dos protagonistas do reatar desse fio." (2007, p. 25) Desse modo, em continuidade com a poesia dos anos 40, a poética dominante na poesia de 60 teria procurado reativar a vertente mais radical da tradição modernista; ao passo que a geração seguinte mostrou-se mais interessada em recuperar a "tradição baudelairiana" (2007, p. 41), com a qual Martelo identifica o tom cético e desesperançoso, o constante interrogar-se sobre si mesmo, a consciência da fragilidade da poesia, de sua ineficácia e inutilidade, dentro do que ela chama de "tendência alegórica", estudada principalmente por Walter Benjamin, Paul de Man e Craig Owens (2007, p. 37). A menos que o método escolhido de ordenar a poesia portuguesa "entre deslocamentos e tensões" dê conta de descrever poéticas mais híbridas, não se faz necessário afirmar aqui que a poesia eugeniana também se modula entre a consciência de crise e fragilidade da palavra poética, trabalhando certa dimensão de dúvida e hesitação - embora tais aspectos talvez apareçam de maneira mais destacada na poesia da geração de 70 e 80, conforme aponta Martelo.

210 Cf. Kátia Muricy. "Benjamin: política e paixão". Os sentidos da paixão. São Paulo: Funarte/Companhia das Letras, 2006, pp. 497 a 508. 
Diante deste quadro, a poesia moderna movimenta-se de modo paradoxal. Ainda segundo Paz, ela exalta a mudança, intenta a ruptura em busca da palavra nova capaz de dizer o homem novo. Ao celebrar a mudança e utilizar as potencialidades da técnica, afirma o princípio da modernidade. Porém, sendo crítica de si mesma, já que, diante das novas exigências, precisou refletir sobre seus próprios processos, a poesia moderna também é uma “apaixonada negação da modernidade” (PAZ, 1984, p. 53).

Uma das formas de ruptura com a modernidade, ou alternativa ao mover incessante do tempo histórico, presente na poesia eugeniana, como temos demonstrado, é o regresso ao passado, o retorno à unidade da natureza, em que se recupera a memória mítica das palavras e a concepção de outro tempo. Contudo, conforme assinala Paz, a busca do elo com o passado na poesia moderna não representa um regresso ao tempo cíclico dos astros, nem constitui uma fuga em relação ao presente, mas significa, antes, a tentativa de inserção do homem na história:

\begin{abstract}
A nostalgia moderna de um tempo original e de um homem reconciliado com a natureza expressa uma atitude nova. Ainda que postule, como os pagãos, a existência de uma idade de ouro anterior à história, não insere essa idade em uma visão cíclica do tempo; o regresso à idade feliz não será a consequência da revolução dos astros, mas da revolução dos homens. Na verdade, o passado não volta: os homens, por um ato voluntário e deliberado, inventaram-no e instalaram-no na história. O passado revolucionário é uma forma que o futuro assume, o seu disfarce. [...] O tema da instauração de outra sociedade é um tema revolucionário, que insere o tempo do princípio no futuro; [...].
\end{abstract}

(PAZ, 1984, pp. 56 e 58)

O retorno à origem deixa entrever qualquer novo princípio. A poesia eugeniana ensaia, frequentemente, o gesto de recomeço. Como vimos no poema acima, na tentativa de recompor uma imagem arquetípica, em busca do "mar diurno e sem palavras”, Eugénio de Andrade procura aprofundar a percepção e alargar a sensação do instante, em resistência, pois, à sucessão linear do tempo histórico, que trabalha sobre o princípio da separação. No poema “Até amanhã”, tudo está em junção: o corpo é continuidade do "horizonte". A palavra roça a "espuma" do mar e o "grito" é também silêncio. Através do recurso da analogia, o poema consegue restituir a sensação de simultaneidade: na imagem procurada habita uma porção de tempos em "encontro e em 
confronto". ${ }^{211}$ As imagens em anelo suscitam forças heterogêneas em equilíbrio, redes de afeto e desejo.

No entanto, diríamos que o título do poema poderia evocar aquela pergunta que tanto assola o poeta moderno: como fazer perdurar, Até amanhã, a imagem do homem reencontrado? Como permanecer entre ruínas, combater o constante envelhecimento e manter acesa a esperança? Ainda que o poema "Até amanhã" repouse na simultaneidade da imagem e no presente instantâneo do corpo, tudo está em movimento de expansão: a poesia também é encadeamento, discurso, articulação. Conforme bem demonstra "Poesia e resistência" de Alfredo Bosi: embora a poesia moderna tenha desconfiado da representação e da relação referencial entre linguagem e mundo, toda palavra poética também compõe, ondula e desdobra redes de sentido, isto é, "a realidade paciente do conceito" (BOSI, 1977, p. 22). Ou seja, trabalha e depende do encadeamento lógico do discurso, ainda que dele procure se libertar. Assim, se neste poema, a palavra consegue o efeito de rarefação - recurso que liberta a imaginação e nos dá a sensação de transcendência - em outros poemas, tal como "Canção", último do livro, o sujeito eugeniano volta a expressar a frustração diante de qualquer coisa não conseguida:

\section{Canção}

Tu eras neve.

Branca neve acariciada.

Lágrima e jasmim

no limiar da madrugada.

Tu eras água.

Água do mar se te beijava.

Alta torre, alma, navio,

adeus que não começa nem acaba.

Eras o fruto

nos meus dedos a tremer.

Podíamos cantar

ou voar, podíamos morrer.

Mas do nome

que maio decorou,

\footnotetext{
${ }^{211}$ Expressão de Alfredo Bosi, empregada para explicar o complexo jogo temporal que habita a poesia, em que se "encontram e se confrontam" tanto os tempos descontínuos, díspares da experiência históricosocial, quanto o "tempo relâmpago" da figura, ou o tempo ondeante e cíclico da expressão sonora, etc.: "É nessa altura que se defrontam os tempos: o tempo corpóreo, inconsciente, cicloide, ondulatório, figural, da frase concreta; e o tempo 'quebrado' de histórias sociais afetadas pela divisão do trabalho e do poder, mas já capazes de criticar o poder, a divisão, a reificação” (BOSI, 1977, p. 118).
} 
nem a cor

nem o gosto me ficou.

(ANDRADE, 1966, p. 150)

Esse último poema parece, novamente, dialogar com poemas precedentes, recuperando certas cenas de escrita, como a "neve" que aparecia também em "Adeus" de As palavras interditas (1966, p. 100), lida como indagação da página branca, bem como o espaço intermediário do "navio" deste mesmo livro, a percorrer novamente o "adeus que não começa nem acaba" - verso acima que ecoa o trecho "iremos juntos separados" e a imagem dos "braços hesitantes" de "Viagem" (1966, p. 106), poema do mesmo livro anterior. Retoma também, através do trecho "Tu eras água./ Água do mar se te beijava", a "orla dos meus versos", do poema "Post-scriptum", último de As palavras interditas, em que o corpo amado "flutuava sem limites" no mar, "ainda quente dos beijos que te dei" (1966, p. 123). E, por fim, evoca o "fruto nos dedos a tremer" de As mãos e os frutos, bem como a cena final dos pássaros, do poema homônimo ao segundo livro, “Os amantes sem dinheiro" (1966, p. 64), em: "podíamos cantar ou voar, podíamos morrer”.

Percorre-se, nas três primeiras estrofes, a trajetória dialética dessa poética, movida entre tensões: ora triste e pesarosa como a "lágrima" e o "adeus que não começa nem acaba", ora pura como a "neve" no "limiar da madrugada", e amorosa: "água do mar se te beijava", etc. As imagens que conhecemos de outros poemas são nomeadas em pequenas variações dentro da complexa rede imagética dessa poesia. Em todas essas situações, fala-se do repouso (instável) de cada uma das imagens conseguido na própria mutabilidade do tempo: "neve acariciada", "água do mar", "frutos nos dedos" - ainda que a "tremer", prestes a "morrer", no "limiar da madrugada" e na inconstância do “mar”. Embora frágeis e instáveis, elas evocam uma pluralidade de afetos e uma energia contagiante que se depreende da multiplicação constante das imagens. Assim, se elas expressam a iminência da mudança, também apresentam novas alternativas de experienciar a realidade, principalmente através daquilo que Octavio Paz denominou "outridade" 212 : na relação com o outro, seja com o "tu", seja com o mundo fenomênico, pode o ser transcender, e a palavra recomeçar.

\footnotetext{
${ }^{212}$ Definida como a experiência tanto do "amor, da imagem, da Aparição" (1982, p. 162), a "outridade" é um fenômeno que se dá quando o sujeito consegue "perder-se no Outro": "Cair, perder-se, ser um com o Outro. Esvaziar-se. Não ser Nada - ser tudo: ser. Força de gravidade da morte, esquecimento de si,
} 
Mas, a despeito do encontro e da intensidade do instante, a estrofe final apresenta uma brusca interrupção no processo de intersecção entre as imagens, anunciada em tom desesperançado. O "nome" apreendido em "Maio" - mês primaveril no hemisfério norte: tempo de recomeço, como prenunciava "Até amanhã" -, não perdurou. A memória não pode mais resgatá-lo e a "juventude" se quebrou. Tudo, mais uma vez, envelheceu.

Nesse corte abrupto caberia o conflito denominado por Bosi entre a "visão fulmínea da imagem instantânea" e a "potência expansiva do discurso", latente no poema moderno:

Nos percursos da imagem, por mais que se evite a distância não se consegue nunca suprimi-la. A fusão, que se deseja e não se alcança produz um desconforto que semelha a angústia do cão mal amado pelo dono que, no entanto, não sai nunca da sua frente. A imagem, fantasma, ora dói, ora consola, persegue sempre, não se dá jamais de todo.

(BOSI, 1977, p. 15)

Embora radicada na experiência do corpo e dos afetos, e às andanças do "devaneio pré-onírico", segundo Bosi, cada palavra é ainda um processo novo e "transubjetivo de expressão", ou seja, assenta-se também na experiência cultural: é sempre uma palavra "articulada": "A superfície da palavra é uma cadeia sonora. A matéria verbal se enlaça com a matéria significada por meio de uma série de articulações fônicas que compõem um código novo" (BOSI, 1977, p. 21). Dentro dessa série de encadeamentos, a imagem já não é a mimese inicial, mas constitui-se como diferença. A linguagem é simultaneamente "sequência e estrutura", "movimento e forma", "curso e recorrência" (BOSI, 1977, p. 25):

Sem a potência discursiva do discurso, que tudo permeia, a imagem, absoluta, poderia dar a sensação de algo empedrado: o meio do caminho o meio do caminho o meio do caminho a selva a selva a selva. Mas na corrente do texto nada existe de já feito, tudo está-se

abdicação e simultaneamente repentino se dar conta de que essa Presença estranha somos nós também. Isso que me repele, me atrai. Esse outro é também eu. [...] A experiência do Outro culmina na experiência da Unidade. Os dois movimentos contrários [de repulsa e fascinação] se implicam. Atirando-se para trás já se dá o salto para adiante. O precipitar-se no Outro apresenta-se como um regresso a algo de que fomos arrancados. Cessa a dualidade, estamos na outra margem. Demos o salto mortal. Reconciliamos conosco. [...] No encontro amoroso, na imagem poética e na teofania, conjugam-se sede e satisfação: somos simultaneamente fruto e boca, numa unidade indivisível" (1982, pp. 160, 161 e 165). Rompe-se a dualidade entre o sujeito e o objeto. 
fazendo. Abre-se em cada imagem um vazio - cheio de desejo ou de espera - que reclama a plenitude da relação.

(BOSI, p. 1977, p. 34)

Temos assim que a tensão entre "atomização" e "infinitude", apontada por Bosi, é concomitante à relação paradoxal entre o poema moderno e a história. A vontade de retração da linguagem como resistência ao fluir incessante e aniquilante do tempo e também do discurso histórico, com seus mecanismos predominantemente racionais, esbarra em uma dificuldade de ordem natural da própria linguagem: corpo vivo, tão subjetivo quão social.

O silêncio e o esvaziamento procurados no isolamento de uma dada imagem instantânea ou na própria rarefação da linguagem - silêncio do "mar diurno e sem palavras" do poema acima -, em que se busca talvez cessar e reverter o sentido usual e histórico, pode também, por seu turno, dissipar-se até a própria morte da mensagem, como afirma Bosi (1977, p. 107). O silêncio, gesto de recomeço tão procurado pela poesia moderna, é simultaneamente fértil e estéril. Por um lado, emana sentidos latentes, ainda não pronunciáveis, mas pressentidos em sua capacidade de transcender a realidade conhecida. Mas por outro, incorre também no risco de dissipar-se ou de ruir em mera tautologia. $^{213}$

Desse modo, a hesitação e a angústia constituem, na poesia eugeniana, mecanismos críticos. Manifestam incertezas diante da própria potencialidade afirmativa da linguagem. Não raro, portanto, que aos momentos de fulguração da palavra se suceda a sombra de seu esgotamento iminente, como podemos ver no último poema de um

\footnotetext{
${ }^{213}$ Octavio Paz chama a atenção para algo semelhante quando trata da tensão entre "analogia" e "ironia" na poesia moderna: a primeira como "crença na correspondência entre todos os seres e os mundos" (PAZ, 1984, p. 79), em que se procura, na intersecção das imagens, um modo de resistência ao mecanismo racional predominante no pensamento moderno; e a segunda como reconhecimento da insuficiência de tal procedimento: "A ironia nega que o universo é uma escrita. A palavra poética acaba em uivo ou em silêncio" (PAZ, 1984, p. 100). Na poesia eugeniana, o reconhecimento crítico não se reveste propriamente do tom irônico, mas se dá como expressão direta de dúvida dolorosa e frustração. Citamos também, desta vez mais especificamente sobre a poesia de Eugénio de Andrade, o trecho de Eucanãa Ferraz em "Eugénio: animal amoroso" (Revista Relâmpago. № 15. Lisboa: Assírio \& Alvim, 10/2004), que sublinha a tensão entre a "vigília crítica" e a aspiração de "adormecer" na inconsciência da natureza: "O relaxamento, a um passo do cancelamento das vontades racionais do sujeito, seria um patamar superior de criação, no qual o poema estaria pronto para receber (para ser) o esplendor da natureza" (2004, p. 17). Porém, conforme explica o crítico, o "adormecer" da completa entrega também oferece risco, já que prejudica o estado de vigília, a qual toda criação exige. Através desse conflito, o poeta postula que toda escrita é fracasso, já que nela se instala a consciência da "descontinuidade entre poema e natureza" (FERRAZ, 2004, p. 19). O repousar na imagem comparar-se-ia à entrega total à natureza apontada por Ferraz, sempre perseguida, nem sempre concedida.
} 
livro tão afirmativo quanto Até amanhã. A última estrofe de "Canção" faz vibrar a voz do sujeito eugeniano, entoada pelo verbo em primeira pessoa, "nem o gosto me ficou". Pela relação metonímica entre "cor", "gosto" e a estação primaveril de "Maio", sabemos que o "nome" é também a "palavra" sob o signo do "fruto", tão evocado por Eugénio de Andrade, e que, mais uma vez, perece nas mãos vazias e solitárias do indivíduo.

\subsection{As “águas" diurnas}

Que cheiro doce e fresco, por entre a chuva, me traz o sol (Eugénio de Andrade, 1966, p. 168)

Se levarmos em conta a dinâmica entre os elementos "noite" e "dia" na poética eugeniana desde As mãos e os frutos, cujos últimos versos suplicavam:

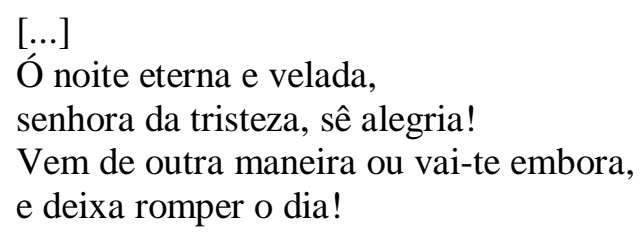

(ANDRADE, 1966, p. 56)

Ou como exposta em "Nocturno de Fão" - poema citado com certa frequência, de Ostinato rigore: "De palavra em palavra / a noite sobe / aos ramos mais altos / e canta / o êxtase do dia" (1966, p. 224) -, temos que todo o esforço de transfiguração do fazer poético eugeniano é metaforizado na movimentação entre noite/dia, por vezes acompanhada dos pares outono/verão, ausência/plenitude, tristeza/alegria, chuva/sol (como na epígrafe acima), etc. No entanto, não convém tomar esses pares como polos positivos e negativos. A "noite", embora muitas vezes lamentada em sua escuridão e isolamento, decorrente da ausência ou da perda do amado, é também celebrada como palco da escrita eugeniana ${ }^{214}$, onde o poeta trabalha para romper o "dia": "Que palavra

${ }^{214}$ Susan Stewart, em Poetry and the fate of the senses, argumenta que, sendo a atividade poética aquela
que promove o reconhecimento, através dos sentidos, do mundo ao redor tido anteriormente como 
abre a noite à mais pura madrugada?” (1966, p. 51), verso também do primeiro livro. Desse modo, o penúltimo verso do trecho acima, escolhido de As mãos e os frutos, "Vem de outra maneira ou vai-te embora", sugere que a "noite" pode ser também fecunda. Como local da "solidão-a-dois", onde se dá o encontro amoroso ${ }^{215}$, a "noite" é por vezes descrita em termos de plenitude e alegria: "Noite onde a mais bela aventura se escreve exactamente sem nenhuma letra", de As palavras interditas, (1966, p. 110); ou em "Noite transfigurada" do primeiro livro: "Criança adormecida, ó minha noite, / noite perfeita e embalada [...] / ó noite rumorosa como as fontes, / pura alucinação da madrugada" (1966, p. 23) - embora a plenitude amorosa venha mais frequentemente acompanhada do termo "madrugada" do que propriamente "noite", o que implica já a intersecção com o "dia", pela aproximação da alvorada e a iminência da luz.

Se o "amanhecer" constitui o horizonte perseguido pela poesia, em que a virada da luz correspondesse a uma intencionalidade poética na obra de Eugénio de Andrade $^{216}$, em certos poemas de As palavras interditas, no entanto, o "dia" não traz a "perfeição" esperada (uma dada "revelação", relacionada, talvez, à apuração dos

inarticulado, ela representa, por essa razão, uma tentativa de soprepor a "escuridão" e o oblívio: "It will be the argument of this book that the cultural, or form-giving, work of poetry is to counter the oblivion of darkness. [...] To make something where and when before there was nothing". ("O argumento deste livro será o de que o trabalho enformador e cultural da poesia se constitui como oposição à escuridão e o esquecimento. [...] Com o propósito de construir algo no instante e no lugar onde antes nada havia." Tradução nossa). Chicago: University Press, 2002, pp. 2 e 3. De acordo com a autora, não é tanto pela associação à morte ou ao perigo que a escuridão da noite nos apavora - já que a morte não pode ser imaginada senão como o fim do imaginar, o que tornaria a noite apenas um véu entre os mundos, e não um objeto de grande medo em si mesmo. A noite nos causa terror porque apresenta uma contração daquilo que a mente retém como imagem do humano: "It erases and mutes the limits of our being - not as an expansion, but rather as a contraction, of whatever the mind can hold as an image of the human. It is unbearable, this loneliness of the mind working on its own to maintain the outline, the figure, of the person" (2002, p. 2).

${ }_{215}$ Alexandre Pinheiro Torres menciona uma dada aspiração desta poesia para abandonar o topos instintivo e individual da noite a fim de permitir a passagem para uma vida mais diurna e "apolínea". De acordo com o crítico, "a madrugada, a aurora, o dia, com efeito, apontam para um mundo onde existem os outros homens, tantas vezes hostis. Mas ela é símbolo também [principalmente dentro de um vocabulário standard do neo-realismo português, herdado, em larga medida, do romantismo oitocentista, segundo Torres] da presença dos outros homens, da acção, da necessidade de um determinado tipo de intervenção política". Desse modo, a passagem da noite para o dia poderia referir-se à passagem "do instinto à sociedade" ao qual o amante eugeniano cederia por um "imperativo histórico", em "O conflito entre o instinto e a sociedade em As mãos e os frutos de Eugénio de Andrade". 21 ensaios sobre Eugénio de Andrade. Porto: Editorial Inova, 1971, pp. 11 e 18. Dessa maneira, o crítico aproxima esse primeiro livro de Eugénio de Andrade da produção neorrealista: embora o poeta nunca tenha pertencido ao movimento, sua poesia também o teria tornado "bem irmão espiritual dos poetas de raiz socialista da geração de 40 ". Idem, p. 18.

${ }^{216}$ Óscar Lopes apontou para o "movimento ascensional" da poética eugeniana, associado também a esse fator de transfiguração a que aludimos: "Estou de facto em crer que todos os poemas de Eugénio de Andrade supõem a consciência de uma iluminação, de um movimento ascencional, de qualquer gradação fundamentalmente ascendente [...]. E (vitória decisiva) até a morte [...]". Em "Morte e ressurreição dos mitos na poesia de Eugénio de Andrade". Uma espécie de música. Porto: Campo das Letras, 2001, p. 34. 
sentidos e ao aprofundamento do instante poético, jamais dissociados da noção de laboração e rigor), transcorrendo-se, antes, de modo incessante, e subjugado ao fluir sem sentido do tempo histórico: "Foi apenas mais um dia que passou / entre arcos e arcos de solidão" (1966, p. 103); "Que morte é a sombra deste retrato, onde eu assisto ao dobrar dos dias, órfão de ti” (1966, p. 104); “Aqui estou, alto como o trigo, / sangrando nas pétalas do dia" (1966, p. 112); e finalmente: "cansado de ser homem durante o dia inteiro" (1966, p. 115).

Em Os amantes sem dinheiro, livro em que a escrita eugeniana se debruça sobre as memórias e a influência materna, a "noite" aparece em apenas dois poemas, como em: "a noite é enorme e todo o meu corpo cresceu", de "Poema à mãe" (1966, p. 83), e "meu coração escreve na noite como quem chora", de "Choro" (1966, p. 86). Em ambas as situações, a "noite" insere-se na descrição do momento presente de um sujeito triste e isolado que tenta rememorar as "manhãs de oiro" da infância, evocadas repetidamente desde o prefácio do livro. Assim como o "outono" em oposição ao "verão", a "noite" do presente contrasta com o "dia" pleno do passado ${ }^{217}$. Conforme vimos na análise deste livro, a escrita eugeniana se autoexamina a fim de interferir e operar como mediação entre tempos radicalmente cindidos (como "noite" e "dia"), rompendo com a rigidez do passado para movimentar-se e alargar a percepção do tempo presente, à procura, talvez, de uma "noite" mais auspiciosa: "Boa noite. Eu vou com as aves!" (1966, p. 83).

Em Coração do dia (1956-1958), livro breve, composto de apenas treze poemas e dedicado à mãe do poeta ${ }^{218}$, a escrita eugeniana propõe, de maneira semelhante, penetrar o "dia ensolarado" e o "verão quente" do passado. A "noite", por sua vez, também aparece mais frequentemente como local de enunciação do sujeito isolado. Em alguns momentos, no entanto, depreende-se, de seu cenário melancólico, certo contraste, contraponto nem sempre encarado negativamente, a sugerir alguma riqueza escondida, passível de ser trabalhada pelo poeta. ${ }^{219}$ Um exemplo é o penúltimo poema, "Canto rouco", que, como muitos do livro, se dirige à figura materna. O sujeito evoca

\footnotetext{
${ }^{217}$ A "tarde" também é descrita em Os amantes sem dinheiro como um período decadente, se comparada à "manhã" primeva, mais pura e plena. Contudo, em outros momentos, a melancolia vespertina também aparece como algo passível de ser transmutado pela escrita. Cf. o poema "Rumor", 1966, p. 85.

${ }^{218}$ A mãe de Eugénio de Andrade faleceu em 14 de março de 1956. A dedicatória, "À memória de minha Mãe", abre o quinto livro da coletânea.

${ }^{219}$ Como sugere Óscar Lopes em "A mãe d'água, ou a poesia de Eugénio", “o 'oiro' nesta poesia" (elemento associado à luz, ao dia, ao verão) "está sempre em acorde (ainda que não o diga) com certa melancolia" (LOPES, 2001, p. 40).
} 
uma "noite" triste do passado, mas que, não obstante, é lembrada com ternura e saudade:

\section{Canto rouco}

Antes que perca a memória

das pedras do adro, antes do corpo ser um só e quebrado ramo sem água, devolvei-me o canto rouco e desamparado do harmónio na noite.

Mãe!, desamparado na noite.

(ANDRADE, 1966, p. 170)

Ao recuperar certos elementos presentes no prefácio de Os amantes sem dinheiro, que descrevia a "casa da Eira" e a "casa do Adro", esta última associada à "música do harmónio" que a mãe sacava de um velho baú para cantar ao filho, "Canto rouco" também convoca momentos recordados de comunhão materna. Ao momento estéril do presente (por pouco, um "ramo sem água"), em que o sujeito se sente cindido e abandonado (quase "um só corpo" e "quebrado"), pretende-se justapor uma "noite" do passado, ainda que, ela também, melancólica.

A primeira menção de "desamparado" é atribuída, juntamente com o adjetivo "rouco", ao soar do "harmónio" naquela "noite", reportando-se à figura triste da mãe, assim descrita também em alguns poemas de Os amantes sem dinheiro. ${ }^{220}$ Porém, a repetição do termo no último verso, "desamparado na noite", descolado do corpo principal do poema, parece remeter à voz do sujeito no tempo presente, que lamenta seu

\footnotetext{
${ }^{220}$ Como, por exemplo, no poema "Canção para minha mãe", que descreve uma mulher a "cantar de cabelo despenteado", por cujas pernas escorriam "águas mortas de abandono", e pelos braços "frutos maduros de outono" (ANDRADE,1966, p. 67). Como é comum encontrar mencionado nas biografias de Eugénio de Andrade, a mãe do poeta parece ter sofrido bastante durante a gravidez e a primeira infância do poeta, ao ver-se sozinha e sem recursos para cuidar do filho, principalmente em uma sociedade conservadora como era a portuguesa na primeira metade do século XX. Cf. Introdução à Poesia de Eugénio de Andrade. Arnaldo Saraiva. Porto: Fundação Eugénio de Andrade, 1995. Óscar Lopes, sobre essa figura, também afirma: "Muito nova ainda quando o poeta nasceu, animou uma comunicação dual muito complexa e uma inserção muito íntima do poeta na sua infância rural." (LOPES, 2001, p. 88). Eugénio de Andrade nunca estabeleceu relações com o pai, e alguns de seus textos, conforme ainda Lopes, se inserem "no epicentro da tensão irresolvida com a figura paterna, portador da Lei de muitos interditos, e também de uma sociedade de exploração de que a ligação mãe-filho, e mãe-terra se constituem em núcleo de resistência e contrapólo edénico" ( LOPES, 2001, p. 136).
} 
próprio estado atual, também "descolado" do universo de comunhão de outrora, entregue ao esquecimento ou ao aniquilamento gradual na escuridão de uma "noite" infértil e sem canto. Assim, embora também triste, a "noite" pretérita do harmónio revela-se fecunda para o canto eugeniano.

Nesse mesmo contexto de um sujeito isolado que invoca o canto, inserimos o primeiro poema do livro, cujo título, "Introdução ao canto", exprime agora mais explicitamente sua condição de poema de abertura. Nele, identificamos um certo tom que se move, por um lado, entre o desespero e a exasperação, produzido principalmente pela repetição imperativa "Ergue-te" e pela locução adverbial "ao menos"; mas que, por outro, propõe também uma suave e terna exaltação, como sugerem as expressões “fragrância”, “jasmim”, "primavera”, etc.:

\section{Introdução ao canto}

Ergue-te de mim, pura chama do meu canto. Luz terrestre, fragrância.

Ergue-te, jasmim!

Ergue-te, e aquece a cal e a pedra, as mãos e a alma. Inunda, reina, e amanhece.

Ao menos tu sê ave, primavera excessiva! Ergue-te de mim: canta, delira, arde!

(ANDRADE, 1966, p. 153)

Há ecos, neste poema, do livro anterior, Até amanhã, não só no modo afirmativo com que o sujeito convoca o canto para "aquecer a cal e a pedra", mas também na escolha das imagens: o canto é equiparado à "chama", à "luz terrestre", ao "ardor" e ao "amanhecer". O movimento buscado é ascensional. Por outro lado, ou a um só tempo, o canto também "inunda" como a "água", expandindo-se em direção horizontal e "terrestre", aliciando, assim, uma série de oposições, como corpo ("mãos") e "alma", "fogo" e "água", "pedra" e "ave", etc. Além disso, através da enumeração cruzada de palavras pertencentes a campos semânticos diferentes, o poema opera como uma composição sinestésica, em que a "fragrância” ou um “jasmim” podem iluminar, 
"arder", "aquecer" voar ou "inundar". Nesse sentido, o imperativo do último verso, "delira", é significativo: o "canto", assim como o delírio e o sonho, desordena os elementos sistematicamente separados pela razão. Aproxima o sujeito do corpo, "aquece" o cotidiano arrefecido pelos modos de organização excessivamente racionalizados da vida moderna. $\mathrm{O}$ tom que oscila entre o desespero e a exaltação nos revela a voz de um sujeito cindido a quem, talvez, já tenha se tornado insuportável pensar, raciocinar, remoer - habitar um mundo onde o conhecimento obtido através do exercício dos sentidos, da imaginação, da percepção do mundo natural e do sonho, e principalmente da prática da poesia já tenha se tornado "inútil" ${ }^{221}$. Por essa razão, o verso "ao menos tu sê ave" nos apresenta, em um relance trágico, a intimidade triste e desiludida desse sujeito, cuja voz precipita-se do contexto afirmativo do poema, e também do projeto eugeniano mais geral de erguer a linguagem para além do sujeito, em sua ânsia de encontro e transcendência.

A "água", neste quinto livro da coletânea, é identificada como signo central ${ }^{222}$, ao redor do qual se reúnem as aspirações de vida e fecundidade de um sujeito silenciado pela dor e pelo abandono. Uma das acepções mais recorrentes desse elemento simbólico na literatura é aquela que se relaciona com o inconsciente e com o sonho. ${ }^{223} \mathrm{Na}$ poesia eugeniana, a simbologia tradicional da água sobrevive, como percebemos acontecer também com os outros signos recorrentes. No entanto, especialmente neste livro

\footnotetext{
221 "A poesia é um alimento que a burguesia - como classe - tem sido incapaz de digerir". Octavio Paz. $O$ arco e a lira. Rio de Janeiro: Nova Fronteira, 1982, p. 48.

${ }^{222} \mathrm{Em}$ um total de treze poemas, a "água" é o elemento recorrente em dez deles, ou seja, em quase oitenta por cento das composições do livro. Nota-se que a "fonte", tão presente nos livros anteriores, não aparece em Coração do dia, estando a "água" mais ligada à densa correnteza do "rio" (poemas 4, 6 e 8 ) e do "mar a pique" (poemas $7,8,13$ ) - embora o "orvalho", elemento que aproximamos à realidade primeva da "fonte", também apareça três vezes (poemas 2, 4 e 9). Verbos como "inundar" (poema 1) e "navegar" (poema 2), assim como o signo do "barco" (poemas 2 e 6), também participam na composição de uma imagética mais caudalosa da(s) "água(s)" neste livro. Em sua instância mais melancólica, apontamos a "chuva" (poema 11), a "lágrima" e os "olhos molhados" (poemas 5,6 e 8).

${ }^{223}$ Conforme nos ensina o dicionário de símbolos Metzler Lexikon literarischer symbole (Org. Günter Butzer e Joachim Jacob. Stuttgart: J.B. Metzler, 2008, pp. 414 e 415), já Goethe constatara, em sua dinâmica elementar, que "a alma do homem" se assemelha à água. Para Jung, no contexto da interpretação dos sonhos a água é símbolo central da profusão desordenada do inconsciente. Mesmo parada, como o espelho d'água no mito de Narciso, encontramos a projeção clássica do inconsciente. A "água", por sua fluidez e constância, constitui uma das substâncias mais essenciais do sonho, que sem cessar "transforma a substância do ser". No livro já citado, Óscar Lopes retoma essa linha interpretativa da "água" e suas relações com forças inconscientes: "Não é necessário recorrer a uma hermenêutica de psicanálise, de mitologia comparada ou do tipo da de G. Bachelard para reconhecer que sobretudo as palavras mais comuns como água chegaram, sem grande investimento afectivo, a significar uma dada coisa a partir de múltiplas imagens infantis (ou "primitivas") designatoriamente mais difusas e carregadas de afectividade, alvejadas por impulsos primários que sentimos deslaçarem-se de novo (decerto modificados) em estado de relaxe intelectual e prático, liberação poética ou plástica, sonho, devaneio" (LOPES, 2001, p. 142).
} 
dedicado à mãe, em que figura como signo central, a "água" indigita significações mais particulares dentro da arte poética eugeniana, associando-se ao tema da memória, da infância, do afeto maternal e de suas relações específicas com o "canto".

Segundo Óscar Lopes em “A mãe d'água”, a "água” é uma das imagens mais "plurissignificativas" e "plurivalentes" da poesia eugeniana ${ }^{224}$, que, "como elemento mítico primordial, tanto tem interessado à teoria psicanalítica, e a que, de qualquer modo, despercebidamente associamos tantas das nossas experiências mais difíceis de exprimir, portanto de apreender" (LOPES, 2001, p. 44). Uma das instâncias mais examinadas pela crítica psicanalítica é o caráter feminino e maternal do elemento "água" 225 , e algumas de suas contribuições são pertinentes para a nossa leitura deste quinto livro da coletânea. No entanto, dado a variedade de significações que a imagem da "água" pode suscitar nesta poesia, tentaremos nos deter, conforme o recorte proposto, nas relações deste signo com o "canto" e com a arte poética eugeniana.

Em A água e os sonhos, Gaston Bachelard afirma, de modo sugestivo para a análise desse signo, que em todo elemento líquido da poesia, seja no emprego das imagens aquáticas, seja na utilização das vogais líquidas, por exemplo, subsiste o próprio "desejo caudaloso" de linguagem ${ }^{226}$. Em uma relação de continuidade, aproxima a "palavra da água" da "palavra humana":

\footnotetext{
224 “Água, ou (e algo diversamente) águas, plural de ressonância bíblica, têm em Eugénio de Andrade, muito de princípio vital, erótico, seminal; podem ser matinais ou anoitecidas, e neste último caso dir-se-ia imagem da diluição na morte, mais ou menos à vista; podem estar ocultas, por pudor ou repressão, mas também romper, falicamente nuas e/ou duras, se não mesmo tresmalhadas, sentimo-las felizes, mas também em demência; como acontece com a mãe das Musas helênicas, Mnemósine, é de águas que brota a memória (memória atávica, memória da espécie, que os mortos afogaram no curso do Letes, ao descer aos Infernos); é na água que navegam as palavras, a poesia; nada surpreende que aquosa seja também a imagem da música, do sonho, do sono profundo, e do próprio ser 'sem memória', portanto da morte" (LOPES, 2001, p. 44).

${ }^{225} \mathrm{Em}$ A água e os sonhos, Gaston Bachelard cita como exemplo o trabalho de Marie Bonaparte sobre a obra de Edgar Allan Poe, em que a crítica analisa a adesão do autor a certos "quadros imaginários relacionados com as recordações da infância", aproximando o sentimento da natureza do amor filial. Um dos elementos examinados é o "mar", definido como um dos maiores e mais constantes símbolos maternais, cujo canto profundo pode nos fazer lembrar da voz maternal. Ao lado do "mar", Bachelard ainda cita a "água" dos "rios" e dos "lagos" como "metáforas lácteas" dentro da dinâmica da imaginação criadora: "[...] Toda água é um leite. Mais exatamente, toda bebida feliz é um leite materno". Nesse contexto, a "boca" e os "lábios", tão recorrentes também na poesia eugeniana, pertenceriam, conforme Bachelard, ao "terreno da primeira felicidade positiva e precisa, o terreno da sensualidade permitida". $A$ água e os sonhos - ensaio sobre a imaginação da matéria. São Paulo: Martins Fontes, 2002, pp. 121 e 122. Mais especificamente sobre a poesia de Eugénio de Andrade, Óscar Lopes e principalmente Carlos Mendes de Sousa também se debruçaram sobre a metáfora materna da água. Cf. nota 18.

${ }^{226}$ Após citar como exemplo um hino do Rig Veda, que relaciona, em duas linhas, o "mar" e a "língua" ("assim como o mar está sempre inchado de água, assim a língua está incessantemente cheia de saliva"), Bachelard afirma: "A liquidez é um princípio de linguagem; [...] A liquidez é, ao nosso ver, o próprio desejo de linguagem. A linguagem quer fluir. [...] A água é a senhora da linguagem fluida, da linguagem
} 
[...] A linguagem das águas é uma realidade poética direta, que os regatos e os rios sonorizam com estranha fidelidade as paisagens mudas, que as águas ruidosas ensinam os pássaros e os homens a cantar, a falar, a repetir, e que há, em suma, uma continuidade entre a palavra da água e a palavra humana.

(BACHELARD, 2002, p. 17) 227

$\mathrm{Na}$ poesia eugeniana, desde os primeiros poemas da coletânea, em que o universo de solidão e tristeza do eu lírico é interrompido pela chegada do amado ${ }^{228}$, observamos o elemento "água" associado ao "canto" ou a uma "espécie de música" (para empregar a expressão de Óscar Lopes ${ }^{229}$ ), nascida do ritmo amoroso e dos elementos em anelo, que encanta a linguagem, provoca o fluir contínuo de imagens, metaforizado, muito frequentemente, pelo transcorrer do "rio". O "rio" é, ao longo de todo As mãos e os frutos, por exemplo, comparado ao corpo do amado, como no verso "Impetuoso o teu corpo é como um rio / onde o meu se perde." (ANDRADE, 1966, p. 36), ou em "O seu corpo perfeito, linha a linha, / derramava-se no meu” (ANDRADE, 1966, p. 47). A chegada do amado, portanto, também referida de modo sugestivo em "Brotou água onde tudo era secura" (ANDRADE, 1966, p. 31), define-se como a pulsação original de todo encontro e convergência dos elementos: "Nas tuas mãos / estavam os montes os rios / e as nuvens." (ANDRADE, 1966, p. 38); "Por isso, rio foi o nome que lhe dei. / E nele o céu fica mais perto." (ANDRADE, 1966, p. 36). É esse ritmo que faz nascer a poesia, correspondência traçada em versos como: "Para ti rasguei ribeiros / e dei às romãs a cor do lume" (ANDRADE, 1966, p. 25).

sem brusquidão, da linguagem contínua, continuada, da linguagem que abranda o ritmo, que proporciona uma matéria uniforme a ritmos diferentes" (BACHELARD, 2002, pp. 194 e 193).

227 "Nossa tese não se detém nas lições da poesia imitativa. [...] [Mas a] essa preparação dinâmica que produz a audição ativa, a audição que faz falar, que faz mover, que faz ver. [...] Âmbito da imaginação criadora: a imaginação pela palavra, a imaginação pelo falar, a imaginação que desfruta muscularmente do falar, que fala com volubilidade e que aumenta o volume psíquico do ser. Esta imaginação sabe bem que o rio é uma palavra sem pontuação [...]” (BACHELARD, 2002, pp. 194 e 195).

${ }_{228}$ No segundo poema de As mãos e os frutos, o "rio" faz coincidir o ritmo amoroso e o poético, figurando, principalmente, como metáfora para a poesia: "Cantas. E fica a vida suspensa. / É como se um rio cantasse: / Em redor, é tudo teu; / Mas quando cessa o teu canto / O silêncio é todo meu (ANDRADE, 1966, p. 18). Porém, como já prenunciado nesse mesmo poema, o fluxo caudaloso ameaça, constantemente, derramar-se no silêncio, como podemos ver também no poema 30, um dos últimos desse mesmo livro: "Onde me levas, rio que cantei, esperança desses olhos que molhei / [...] Onde me levas?, que me custa tanto! / Não quero que conduzas ao silêncio / de uma noite maior e mais completa" (ANDRADE, 1966, p. 49). Desde o primeiro livro da coletânea, o cantar eugeniano manifesta, de maneira bastante dolorosa, a tensão íntima entre música e silêncio.

${ }^{229}$ Expressão emprestada do livro de ensaios, já citado e bastante conhecido, de Óscar Lopes, sobre a poesia eugeniana (2001). 
Em Coração do dia, a "secura", dentro do cenário atual de solidão do sujeito, identifica-se, da mesma maneira, com o silêncio ou ausência do canto. Por conseguinte, é possível estabelecer uma correspondência, ainda que às vezes indireta, entre o anseio pela "água" e a evocação de uma espécie de "ritmo" poético ou "música" longínqua ${ }^{230}$, a sobrepor a ausência e o silêncio estéril:

\author{
Sem ti \\ E de súbito desaba o silêncio. \\ É um silêncio sem ti, \\ sem álamos, \\ sem luas.
}

Só nas minhas mãos oiço a música das tuas.

(ANDRADE, 1966, p. 156)

Como é frequente nessa poesia, temos neste que é o terceiro poema do livro, as "mãos" solitárias do poeta a acessar as mãos de um "tu" que agora poderia ser a figura materna, que outrora tocava o harmônio, produzindo aquela "música" que tanto motivou o "rumor secreto" de seu canto, já arrefecido no presente da enunciação. Essa "música" da memória, em outros poemas mais diretamente comparada ao elemento "água", contrasta, pois, com o silêncio do presente, escuro, árido, excludente: "sem álamos", "sem luas", "sem ti”, em que a repetição de consoantes líquidas evoca o ritmo distante, ao passo que a repetição das sibilantes poderia remeter a uma ideia de secura, esterilidade. Assim, diante da sensação de perecimento geral, há qualquer coisa que ainda resiste no íntimo do sujeito, associada às lembranças de um tempo em que havia conhecimento e profundo envolvimento com a mãe, com o "outro", com o mundo.

\footnotetext{
${ }^{230}$ Carlos Mendes de Sousa (O nascimento da música. Coimbra: Livraria Almedina, 1992), ao analisar e comparar certos elementos do prefácio de Os amantes sem dinheiro sob o título Chuva sobre o rosto (antologia publicada em 1976, para a qual o próprio Eugénio de Andrade reuniu um conjunto de poemas dedicado à mãe), também se refere à interação mãe e filho, geradora de um "nascimento da música", "o que equivalerá a dizer, o nascer do poema" (SOUSA, 1992, p. 31). Sousa compara o termo "chuva" do título, presente também em um dos mais significativos poemas da antologia, às "lágrimas de oiro" que caíam no rosto do menino, no prefácio indicado: "Agora é o rosto materno que se recorta sob uma idêntica luz metafórica: pode, por semelhança, ler-se a chuva como lágrimas" (SOUSA, 1992, p. 32). Tal equivalência pode também ser compreendida dentro do regime de significações imposto pelo signo da "água", intimamente ligado à "música" do passado, compartilhada por mãe e fillho.
} 
Caracterizada pelo dialogismo e pela procura daquilo que Octavio Paz denomina "outridade",231, a poesia eugeniana é pautada pelo anseio do encontro. Neste quinto livro da coletânea, o "tu" a que ela frequentemente interroga parece se referir mais diretamente, salvo raras exceções, à memória da mãe, como assinala a dedicatória. Já falecida durante a feitura e a publicação do livro, os ensinamentos que tanto iniciaram o menino na poesia tornam-se cada vez mais distanciados no tempo; e a esse esquecimento soma-se a vivência dolorosa de um cotidiano que não se renova.

Conforme assinalamos na leitura de Os amantes sem dinheiro, a relação "eu-tu" na poesia eugeniana é bastante complexa, principalmente por sua abrangência e obliquidade $^{232}$. Mesmo nos momentos em que o "tu" se refere diretamente ao amante, encontramos ecos da relação materna, como já observado na análise de um dos poemas principais do livro, “Os amantes sem dinheiro" (1966, p. 64), e também nos versos de "Retrato com sombra", de As palavras interditas, em que o sujeito, ao aludir à ausência do amado, diz sentir-se "órfão de ti” (1966, p. 104). ${ }^{233}$ Neste mesmo livro, há uma comparação mais explícita no poema "Mar mar e mar": "É evidente que minha mãe me chama / quando uma onda e outra onda e outra / desfaz o seu corpo azul contra o meu corpo" (1966, p. 121): a figura da mãe, do amante e do próprio mar confluem na referência ao "outro". As relações referenciais se cruzam e o resultado constitui aquilo que Óscar Lopes denominou "interpelação constante": o "tu", por sua obliquidade, surge como proposta de comunhão entre poeta e leitor, a se dirigir a um "tu" que "guarda essencialmente a inacessibilidade". (LOPES, 2001, p. 90). Seja na relação com a mãe, seja com o amante, a solidão do sujeito fica sempre ressaltada. Afirma-se, com

\footnotetext{
${ }^{231}$ Sobre a "outridade", ou a experiência do outro, Paz discorre nos seguintes termos: "Assombro, estupefação, alegria, a gama das sensações ante o Outro é muito rica. [...] O Outro nos repele: abismo, serpente, delícia, monstro belo e atroz. E a essa repulsa segue-se o movimento contrário - não podemos tirar os olhos da Presença, nos inclinamos para o fundo do precipício. Repulsa e fascinação. E depois a vertigem: cair, perder-se, ser um com o Outro. Esvaziar-se. Não ser nada - ser tudo: ser. Força de gravidade da morte, esquecimento de si, abdicação, e simultaneamente repentino se dar conta de que essa Presença estranha somos nós também. Isso que me repele, me atrai. Esse outro é também eu. [...] A experiência do outro culmina na experiência da Unidade. [...] O precipitar-se no Outro apresenta-se como um regresso a algo de que fomos arrancados. Cessa a dualidade, estamos na outra margem. Demos o salto mortal. Reconciliamo-nos conosco" (PAZ, 1982, p. 160).

${ }^{232}$ Como esclarece Óscar Lopes, a relação eu-tu na poesia se movimenta de modo diverso da fala comum, em que tais pronomes podem ser substituídos por nomes próprios: "Em poesia lírica, as duas pessoas singulares e básicas da enunciação não são tradutíveis, nem descritíveis, e vivem da tensão em que reciprocamente se definem" (LOPES, 2001, p. 88).

${ }_{233}$ Segundo Bachelard, "Todas as formas de amor recebem um componente do amor por uma mãe" (BACHELARD, 2002, p. 119). Repetimos aqui essa afirmação, já inserida na análise de Os amantes sem dinheiro, por conta de sua pertinência na compreensão do tratamento abrangente dado pela poesia eugeniana ao amor.
} 
isso, a constante procura e desejo por um objeto, por um "tu", pelo "outro", em que o "ser" "sedento de ser", como já afirmava o poeta no prefácio "Poética" (ANDRADE, 1966, p. 10), pode se revelar e transcender. ${ }^{234}$

Em Coração do dia, as distâncias que marcam a estruturação do eixo eu-tu se alargam e se intensificam. Diante da morte da mãe, a escrita eugeniana procura recuperar o elo que se pressente em dissolução. ${ }^{235}$ Em “As palavras", arte-poética e segundo poema do livro, Eugénio de Andrade mais uma vez expõe suas concepções sobre a linguagem e pousa, ao final do poema, a pergunta que parece nortear todo o livro:

\section{As palavras}

São como um cristal, as palavras.

Algumas, um punhal, um incêndio.

Outras, orvalho apenas.

Secretas vêm, cheias de memória.

Inseguras navegam;

barcos ou beijos, as águas estremecem.

Desamparadas, inocentes, leves.

Tecidas são de luz

e são a noite.

E mesmo pálidas

verdes paraísos lembram ainda.

Quem as escuta? Quem

as recolhe, assim,

cruéis, desfeitas,

nas suas conchas puras?

(ANDRADE, 1966, p. 154)

\footnotetext{
${ }^{234} \mathrm{O}$ já referido estudo de Carlos Mendes de Sousa sobre a metáfora materna em Eugénio de Andrade, e por isso, crucial para nossa análise de Coração do dia, indica dois eixos de metaforização na poesia eugeniana: "mãe e desejo" (SOUSA, 1992, p. 26). A esse processo, aproximamos também a configuração enunciativa desta poesia, que, como demonstra Óscar Lopes, obliquamente circunda também o eixo desejo-mãe. Assim, tanto a produção metafórica quanto o esquema enunciativo nesta poesia participam dos mecanismos referenciais propositalmente difusos, que fazem sobressair, antes de tudo, a instabilidade das significações e o movimento de perpétua busca da poesia.

${ }^{235}$ Mais uma vez citamos Carlos Mendes de Sousa, que, embora não trate especificamente de Coração do dia, faz uma afirmação, bastante significativa para a nossa análise, acerca da configuração do "imaginário de raízes maternas" eugeniano: "É sobretudo pela ausência que vemos definir-se o mundo da mãe. Pela ausência e por essa ânsia recuperadora da fruição e aconchego ('doçura') através da qual a criança acede ao mundo, e em particular, ao mundo do desejo" (SOUSA, 1992, p. 32).
} 
Pautada pela transparência da relação com o mundo, Eugénio de Andrade formula sua teoria da linguagem, em que a palavra surge como "cristal" ou "orvalho", a recompor a realidade em sua mais verdadeira pureza: "verdes pássaros lembram ainda". No entanto, não se perde, com isso, sua efetividade histórica, nem sua tendência para o combate, como evidenciam os epítetos "punhal" e "incêndio". Assim, Eugénio de Andrade não só reflete a respeito das potencialidades estéticas como também oferece uma defesa de sua concepção poética, perseguindo um dado modo de organização da experiência.

A segunda estrofe também medita sobre o fenômeno poético e a criação artística, principalmente através do verso "as águas estremecem", que poderia remeter tanto ao processos da memória ("secretas vêm, cheias de memória") que subjazem à escrita, quanto aos caminhos de hesitação e dúvida que a palavra eugeniana percorre (“Inseguras navegam”). O verso também propõe, principalmente pelo emprego do verbo "estremecer", a ideia da escrita como abalo, capaz de despertar as experiências mais "secretas" e profundas do sonho e do inconsciente.

Através do verbo "tecer", na terceira estrofe, que expressa a aguçada consciência artesanal de Eugénio de Andrade, expõem-se as contradições que envolvem a construção do poema: as palavras são tecidas de "luz"; porém, são também a "noite"; "desamparadas", mas "leves"; tão "inocentes" quanto "pálidas" - adjetivo que denota certa tristeza. Dos signos reflexivos, ora móveis e fugazes, como "barco" e "beijo", ora mais duradouros e estáveis, como "cristal" e "punhal", desponta o substancial dessa arte-poética: "desfazer" as palavras em suas "conchas puras". As "conchas" imitam o barulho do "mar": imagem arquetípica que tantas vezes aparece nessa poesia, associada, conforme vimos, a uma dada "música" (que também é "silêncio") primordial; para onde confluem e desaguam as "águas" em todos os seus estágios. No entanto, pergunta-se: "Quem as escuta?"

No artigo já citado, Óscar Lopes examina o esquema enunciativo de Coração do dia e o define como - pela primeira vez na poesia eugeniana - "suplicante" do sujeito poético em relação ao "tu" objeto de desejo. ${ }^{236}$ Segundo explica o crítico, a indagação

\footnotetext{
${ }^{236}$ Anteriormente, o esquema enunciativo se estruturava, segundo Lopes, como "alocução simplesmente assertiva" (LOPES, 2001, p. 85). Em Coração do dia, o crítico também nota que o poeta principia, ocasionalmente, a dirigir-se a si próprio como tu (idem).
} 
pelo interlocutor, agora explícita neste quinto livro da coletânea, empurra o eixo eu-tu para os limites do "drama enunciativo":

[...] O que nestes poemas mais impressiona é o facto de a segunda pessoa ser levada até ao limite do drama afinal inerente a toda comunicação humana afectiva. É que o eixo eu-tu funciona poeticamente, como vimos, de modo a descolar permanentemente os seus dois polos: não prescinde do aqui e agora de cada leitura, mas insere essas coordenadas da enunciação reiterada (do seu acto reiterado de enunciar) no movimento geral de translação, ou metáfora. E, como a poesia é verdade, acabamos por dar conta da precariedade de qualquer minha representação de $t i$ (de qualquer interlocutor), e de mim (de qualquer loquente). Por isso é lícito tomar à letra, e não como apóstrofe, as alocuções do poeta à sua interlocutora, factualmente morta. [...] Essa interpelação profunda pode assumir a proposta de comunhão poeta-leitor no dirigir-se a um $t u$ que, de pessoa humana, guarda essencialmente a inacessibilidade - a inacessibilidade de algo que em particular nos perturba como poço sem fundo de uma referência à procura de objecto.

(LOPES, 2001, pp. 88 e 89)

Embora a questão transcenda a relação materna, como demonstra Lopes, já que o eixo eu-tu, assim como a movimentação dos signos e das metáforas, permanece em “interpelação constante", evidenciando a precariedade da representação e a instabilidade dos significados, a indagação mais direta pelo tu exprime um novo abalo, sem precedentes nos livros anteriores, que parece ser motivado, pelo menos em uma primeira instância, pela morte da mãe, tema principal do livro. O abalo é transposto para o pensar de sua poética, que agora se pergunta sobre o problema da recepção de sua arte e sobre a possibilidade de a poesia perdurar diante de um "tu" cada vez mais oblíquo e distante. ${ }^{237}$

\footnotetext{
${ }^{237}$ Lubomir Dolezel não inclui, dentro da themata fundamental da poética (A poética ocidental - tradição e inovação. Lisboa: Fundação Calouste Gulbenkian, 1990), o problema mais específico da "recepção" da literatura. Contudo, podemos associá-lo ao tema mais amplo da relação entre literatura e mundo, que abriga, segundo Dolezel, a questão central da referencialidade poética. Como se sabe, os autores românticos foram os primeiros a propor a revisão das poéticas e dos preceitos clássicos em torno da arte, e a deslocar o foco da relação de imitação entre obra e natureza, para se concentrarem na tríade artista, obra e natureza, alterando, assim, o estatuto da arte e a situação do poeta (familiares até os dias de hoje). Durante o século XX, na esteira dessas profundas transformações, deslocou-se o foco tradicionalmente dirigido à produção para se investigar também a recepção da obra, em que o leitor passou a ser encarado como agente participativo na composição de sentido e na promoção da efetividade histórica da literatura. Embora tal afirmação necessite maior investigação dos desenvolvimentos desse ponto no decorrer da história da literatura, é certo que a indagação sobre o interlocutor e sobre o alcance geral da literatura tornou-se cada vez mais comum na literatura moderna, até a culminação, na década de 1960, de um grupo de pensadores e professores de universidades alemãs, entre eles Hans Robert Jauss, Harald Weinrich e Wolfgang Iser, que desenvolveu uma série de estudos, a que denominamos, ao conjunto, "estética da
} 
Os poemas "Pequena elegia de setembro", oitavo do livro, e "Entre março e abril”, décimo primeiro, propõem interrogações semelhantes. O primeiro é dirigido à mãe. De maneira nostálgica, o sujeito descreve a imagem da mãe, agora separada do menino: "Estás sentada no jardim, / as mãos no regaço cheias de doçura, / os olhos pousados nas últimas rosas / dos grandes e calmos dias de setembro." (ANDRADE, 1966, p. 164). ${ }^{238}$ Mais uma vez, pergunta-se pela "música" de outrora, neste poema diretamente comparada ao mover das "águas" e a um secreto e longínquo "bosque": "Que música escutas tão atentamente / que não dás por mim? / Que bosque, ou rio, ou mar?" E na penúltima estrofe, impõe-se novamente aquela que parece ser a grande pergunta do livro:

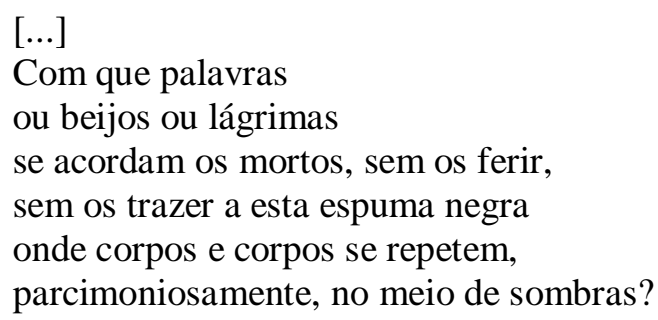

(ANDRADE, 1966, p. 165)

Propõe-se retomar o elo, ainda que precário. Da mesma maneira, a última estrofe do poema 11 ecoa, principalmente através da correlação visual entre "conchas" e "mãos", a pergunta final de "As palavras", "Quem as recolhe [...] nas suas conchas puras?":

$$
\begin{aligned}
& \text { [...] } \\
& \text { Fréseas, } \\
& \text { ó pura memória } \\
& \text { de ter cantado!, } \\
& \text { pálidas, fragrantes, } \\
& \text { entre chuva e sol } \\
& \text { e chuva } \\
& \text { - que mãos vos colhem, } \\
& \text { agora que estão mortas } \\
& \text { as mãos que foram minhas?! }
\end{aligned}
$$

recepção". Sobre essa corrente teórica dentro dos estudos de investigação literária, conferir A literatura e o leitor - textos de estética da recepção. Luiz Costa Lima. São Paulo: Paz e terra, 2002.

${ }^{238}$ Mais uma vez aparece, nesta poesia, o signo da "rosa", lido como metáfora do amor materno. Carlos Mendes de Sousa analisou mais detidamente essa metáfora em seu trabalho, dedicado à relação materna na poesia eugeniana: "Por um lado a consciência de uma necessária separação, por outro lado o desejo de permanecer. As rosas (ou a sua perda) metaforizam as razões da tristeza da mãe; conflito que o poeta procura, de algum modo, resolver, também aqui, pela associação à "voz" da mãe - equivalência em que o guardar da voz corresponde a uma superior experiência ontologizante: preservar a mãe na música do poema" (SOUSA, 1992, p. 70). 
Carlos Mendes de Sousa identifica na "chuva" a metaforização da ausência materna, e aqui valeria a pena transpor um trecho de sua análise sobre um poema ${ }^{239}$ significativo de Chuva sobre o rosto, antologia de poemas eugenianos dedicados à mãe, publicada em 1976, em que a "chuva" figura como elemento central:

Quer se veja o rosto de uma mulher olhando a chuva, quer o rosto da mulher que chora ${ }^{240}$, em qualquer dos enunciados parafrásticos se poderão desenvolver traços dessa figuração melancólica: ou o cenário sombrio, lugar de tristeza, ou, a própria dor, a mágoa, a angústia. A presença da chuva, que irrompe no começo do poema, desencadeia a lembrança, traz consigo a memória da mãe ausente (cuja figura no universo afectivo da rememoração aparece como indissociável desse mesmo cair das águas). Temos, então, a chuva como metaforização da ausência. [...] Com o desaparecimento da simbólica fonte de vida se instaura a crise; tudo é tomado por uma tristeza absoluta: a terra aparece então a reflectir essa dor no sinal da chuva que sobre ela cai incessante, como que o reflexo do próprio rosto sombrio. O poema devolve-nos ainda uma reflexão sobre a passagem do tempo; este agudiza a dor (a mãe está morta, já não ouve a chuva cair) mas a chuva continuará caindo. O dia chuvoso é tempo de evocação (remete para um passado habitado) mas abre-se, simultaneamente, ao enunciar de novos dias (“outra vez a chuva...”), onde se abrirá a possibilidade de recuperar a habitabilidade...

(SOUSA,1992, pp. 33 e 35)

Embora em uma perspectiva mais melancólica, a "chuva", assim como a "lágrima", participa, do mesmo modo, do universo evocado pela águas (ou música das águas) que em outros poemas do livro assume a figura do "rio" ou do "mar". O elo entre mãe e filho constitui-se de um ritmo que permanece nos elementos da natureza, a despeito da ausência materna. Conforme afirma Bachelard, na psique humana, o sentimento da natureza está profundamente assente no amor filial, origem de todo sentimento: "A natureza, começamos por amá-la sem conhecê-la, sem vê-la bem,

\footnotetext{
${ }^{239}$ Transcrevemos aqui o poema "A casa na chuva", de Eugénio de Andrade: "A chuva, outra vez a chuva sobre as oliveiras. / Não sei por que voltou esta tarde / se minha mãe já se foi embora, / já não vem à varanda para a ver cair, / já não levanta os olhos da costura / para perguntar: Ouves? / Oiç̧o, mãe, é outra vez a chuva, / a chuva sobre o teu rosto" (ANDRADE, 1976).

${ }^{240}$ Mais uma vez, Sousa demonstra a equivalência entre "chuva" e "lágrima". No poema "Lágrima", quinto de Coração do dia, Eugénio de Andrade estabelece a relação entre os dois termos e a "água mais pura do dia": signos que remetem ao jogo de significações centrais de sua poética, seja da memória, da relação materna, seja da melancolia do presente: "Dos olhos me cais, / redonda formosura. / Quase fruto ou lua, / cais desamparada. / Regressas à água / mais pura do dia, / obscuro alimento / de altas açucenas. / Breve arquitetura / da melancolia. / Lágrima apenas" (ANDRADE, 1966, p. 159).
} 
realizando nas coisas um amor que se fundamenta alhures" (BACHELARD, 2002, p. 119).

Contudo, em poesia, os sentimentos, como o amor filial, não são transpostos em estado puro, e no caso de Coração do dia, se o amor materno é constantemente evocado, é também na relação com o fazer poético que ele se desenvolve como eixo temático. Em Os amantes sem dinheiro, tal tendência já se verificava: vimos que o sujeito poético eugeniano rasurava o "retrato" do passado com o fim de forjar uma identidade poética, mais livre das fixações e dos anseios maternos. Neste quinto livro da coletânea, dá-se uma nova reflexão sobre a constituição do amor materno dentro da arte poética eugeniana, sobretudo por meio da tentativa de retomar o elo que se pressente cada vez mais distante.

Assim, o sexto poema do livro se desenrola em torno de um "rio" central que atravessa tanto o presente noturno da cidade quanto o passado ensolarado dos "grandes dias de verão" da infância:

\section{Um rio te espera}

Estás só, e é de noite, na cidade aberta ao vento leste.

Há muita coisa que não sabes e é já tarde para perguntares.

Mas tu já tens palavras que te bastem, as últimas, pálidas, pesadas, oh abandonado!

Estás só e ao teu encontro vem a grande ponte sobre o rio.

Olhas a água onde passaram barcos, escura, densa, rumorosa de lírios ou pássaros nocturnos.

Por um momento esqueces

a cidade e o seu comércio de fantasmas, a multidão atarefada em construir pequenos ataúdes para o desejo mais puro e mais sagrado, a cidade onde os cães devoram, com extrema piedade, crianças cintilantes e despidas.

Olhas o rio como se fora o leito 


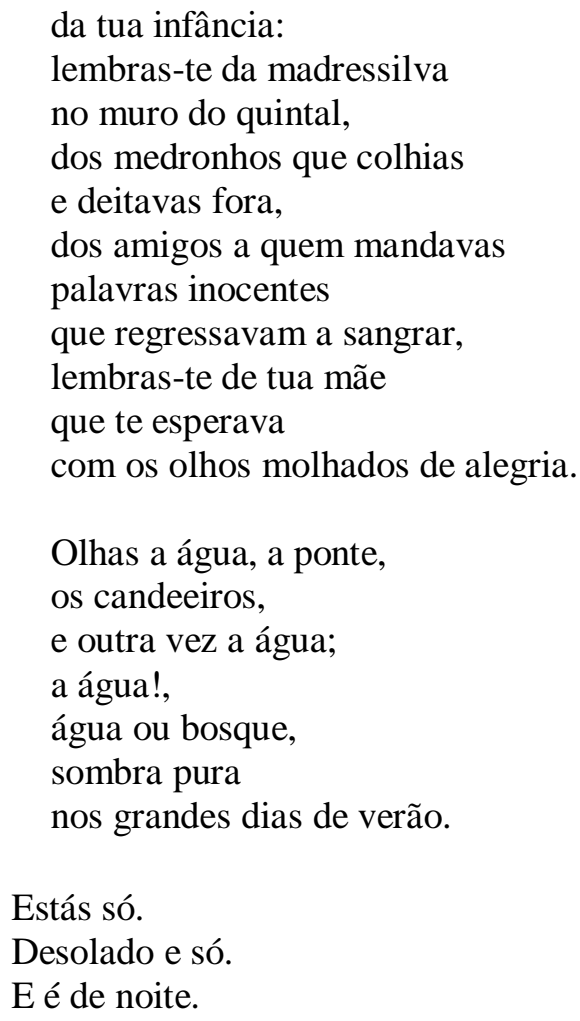

Desolado e só.

E é de noite.

Estás só.

(ANDRADE, 1966, p. 162)

Inicialmente dividida, a cortar o presente e o passado, a "água" mantém aqui toda a ambivalência que encontra na poesia eugeniana: por um lado, é "densa", "escura", noturna; segue o fluxo aniquilante e sem sentido do tempo presente da cidade, "onde cães devoram com extrema piedade, crianças cintilantes e despidas"; e por outro, o "leito" calmo da infância, a refletir a "madressilva", os "medronhos", os "amigos", os "olhos molhados de alegria" da mãe: "águas” tranquilas e narcísicas do passado que espelhavam o entorno.

Em um gesto cheio de ternura, mas também de desespero, o sujeito se volta para a água que corre: "Olhas a água [...] outra vez a água; a água!” A repetição do termo, que se pauta nesse poema pela duplicidade de sentido, prescreve um efeito de reversibilidade, em que se cruzam e se confundem as representações do tempo. Em um ritmo quase alucinante, que destoa da descrição mais contida e realista do restante do poema, misturam-se passado e presente; ecoam vozes mais profundas e inconscientes. Como já insistia o poema de abertura do livro, para que a água "inunde", "reine" e "amanheça" o sujeito desse poema também suplica atenção para esse elemento principal. A repetição articula um apelo para que o próprio sujeito se deixe misturar à 
inconsciência da "água": nela pode a escrita eugeniana realizar o fluir constante do desejo, ritmo caudaloso, procura incessante (como também poderia expressar o título do poema).

No entanto, a última estrofe representa uma quebra trágica do ritmo que avançava, sugerindo um retorno à consciência doída. O sujeito torna a constatar a solidão, a noite, a separação irreparável. O "rio" corre como o tempo presente, indiferente.

Nesse poema, tanto o elemento "água"241 quanto a "luz", presente no verso "grandes dias de verão", encontram-se associados à memória. Relação também estabelecida pelo nono poema do livro, "Da memória", em que os dois signos reaparecem em forma de "orvalho" e "brancura": "Branco, branco e orvalhado, / o tempo das crianças e dos álamos" (ANDRADE, 1966, p. 166). Nessa mesma linha, é significativo o título do livro, Coração do dia, que, tendo sido retirado de um dos poemas mais "reluzentes" do livro anterior (Até amanhã), também parece guardar relações com certa "luz" de um tempo passado. A título de comparação, reproduzimos abaixo o poema referido, "Retrato", de Até amanhã:

\section{Retrato}

Tigre adormecido, coração do dia. Rosto semeado de melancolia.

Noite transparente, primavera escura. Sombra rodeada de mar e brancura.

Tigre adormecido. coração do dia. Puro e violento incêndio de alegria.

(ANDRADE, 1966, p. 144)

\footnotetext{
${ }^{241}$ Como já referido na nota 12, Lopes discorre sobre a relação entre o elemento "água" e a memória: "[...] Como acontece com a mãe das Musas helênicas, Mnemósine, é de águas que brota a memória (memória atávica, memória da espécie, que os mortos afogaram no curso do Letes, ao descer aos Infernos)" (LOPES, 2001, p. 44).
} 
O título do poema, como em diversos momentos da obra eugeniana, aponta para o movimento de revisão do passado e observação dos mecanismos mnemônicos dentro de sua poética. Porém, o que nos salta aos olhos, antes de tudo, é o intertexto com o famoso "The Tyger", de William Blake ${ }^{242}$ : em primeiro lugar, pela imagem central e luminosa do "tigre" - "burning bright", em Blake, e "incêndio" no "coração do dia", em Eugénio -, em contraste com o entorno escuro de "forests of the night" no primeiro e "noite transparente" no segundo ${ }^{243}$; e, em segundo lugar, por ambos os poemas revelarem, na ambivalência das imagens, o espanto diante da criação. ${ }^{244}$

Blake, ao indagar sobre o criador e a criatura, parece sondar também, de modo mais implícito, a arte e a criação artística, principalmente nas estrofes:

In what distant deeps or skies

Burnt the fire of thine eyes?

On what wing dare he aspire?

What the hand, dare seize the fire?

And what shoulder, \& what art,

Could twist the sinews of thy heart?

And when thy heart began to beat,

What dread hand? \& what dread feet?

What the hammer? What the chain?

In what furnace was thy brain?

What the anvil? What dread grasp

\footnotetext{
${ }^{242}$ Reproduzimos aqui o poema original e completo: "Tyger! Tyger! burning bright / In the forests of the night, / What immortal hand or eye / Could frame thy fearful symmertry? // In what distant deeps or skies / Burnt the fire of thine eyes? / On what wing dare he aspire? / What the hand, dare seize the fire? // And what shoulder, \& what art, / Could twist the sinews of thy heart? / And when thy heart began to beat, / What dread hand? \& what dread feet? // What the hammer? What the chain? / In what furnace was thy brain? / What the anvil? What dread grasp / Dare its deadly terror clasp? // When the stars threw down their spears, / And water'd heaven with their tears, / Did he smile his work to see? / Did he who made the Lamb make thee? // Tyger! Tyger! burning bright / In the forests of the night, / What immortal hand or eye / Dare frame thy fearful symmertry?". William Blake - poesia e prosa selecionadas. Edição bilíngue organizada e traduzida por Paulo Vizioli. São Paulo: Nova Alexandria, 1993, p. 54.

${ }^{243}$ Eduardo Lourenço também chamou a atenção para a relação entre este poema e o de William Blake, em "Entre o êxtase e o silêncio" (Paraíso sem mediação - breves ensaios sobre Eugénio de Andrade. Porto: Edições Asa, 2007, p. 32): "Tigre adormecido no coração do dia. É nesta imagem onde acaso passa a sombra de William Blake que tão fundamente unia o céu e o inferno, descobrindo no tigre a inocência infernal da vida, que Eugénio de Andrade inscreve a sua poética dionisíaca autêntica, aquela em que a luz e a sombra são inseparáveis".

${ }^{244}$ No poema de Blake, indaga-se, principalmente, sobre Deus e a alma humana, através do conflito eterno entre o bem e o mal, a inocência e o pecado, representados nas figuras do "tigre" e do "cordeiro" (Cf. José Antônio Arantes. "A imagem de Blake". Introdução de $O$ matrimônio do céu e do inferno - o livro de Thel. São Paulo: Iluminuras, 2001, p. 10). Questiona-se, assim, a associação cristã entre a figura inocente do "cordeiro" e Deus, afirmando a possibilidade de o "tigre", a despeito de sua crueldade e de todo o terror que inspira, também ser uma criatura divina.
} 
Dare its deadly terror clasp? ${ }^{245}$

O "fogo imortal" precede tanto o "tigre" quanto a "mão" que capta a chama para forjar a criatura: "What dread grasp / dare its deadly terror clasp?" O poema interroga a respeito dos "punhos" que contêm e aplacam o "terror" do tigre: esse "fogo imortal", "realidade resplandecente", que o poeta, ser visionário tal como se inscreve na obra de Blake, também consegue pressentir na própria figura do tigre, centro a partir do qual "se escreve" o poema.

No poema de Eugénio de Andrade, o "tigre" "adormece" no rosto do retrato, "semeado de melancolia", sugerindo uma energia contida tão intensa e violenta como a do tigre de Blake: "mar e brancura", "coração do dia", "puro e violento / incêndio de alegria". Pressente-se um impulso primitivo incontrolável, mas silenciado pela dor, pela "sombra rodeada", melancolia associada talvez à vida recalcada na cidade - ambiente predominantemente noturno na obra eugeniana. A luminosidade e a alegria latentes sugerem certo parentesco dessa energia com a da gênese poética, já que a "luz" e a plenitude encontram-se geralmente associadas ao trabalho de transubstanciação da poesia.

Por conseguinte, embora o "rosto" do retrato não seja diretamente nomeado, há indícios de que se trata da figura materna, como a "luz" - ligada à memória e à gênese poética - poderia sugerir; assim como a referência ao "rosto semeado de melancolia", que em outros poemas alude diretamente à figura triste da mãe. Além disso, como já referido, o poema contém a expressão tornada título do quinto livro da coletânea, dedicado à mãe.

Por sua vez, no quarto poema de Coração do dia, um dos centrais do livro, por levar esse mesmo título, nota-se, além da retomada dessa expressão, outras semelhanças com o poema de Até amanhã:

\footnotetext{
245 “[...] Em que altura ou abismo sem par / Ardeu o fogo de teu olhar? /Com quais asas sobe ele ao que clama? / Quais as mãos que seguram a chama? // Qual ombro poderia, ou qual arte, / Essas fibras do peito forjar-te? / E, ao pulsar desse teu coração, / Que pés horrendos, que horrenda mão?// Qual o martelo? Qual a corrente? / Que fornalha fundiu tua mente? / Qual a bigorna? Os punhos são quais / Que atenazam terrores mortais? / [...]". Tradução de Paulo Vizioli, 1993, p. 55.
} 


\section{Coração do dia}

Olhas-me ainda, não sei se morta:

desprendida

de inumeráveis, melancólicos muros,

só lembrada

que fomos jovens e formosos,

alados e frescos e diurnos.

De que lado adormeces?

Alma: nada te dói?

Não te dói nada, eu sei!

Agora o corpo é formosura

urgente de ser rio:

ao meu encontro voa.

Nada te fere, nada te ofende.

Numa paisagem de água,

tranquilamente,

estendes os teus ramos

que só a brisa afaga.

A brisa e os meus dedos

fragrantes do teu rosto.

Mãe, já nada nos separa.

Na tua mão me levas,

uma vez mais,

ao bosque onde me sento

à tua sombra.

- "Como tu cresceste!"

suspiras.

Alma: como eu cresci!

E como tu és,

agora,

pequena, frágil, orvalhada.

(ANDRADE, 1966, p. 157)

O primeiro verso, "Olhas-me ainda", sugere ligação com "Retrato", já que poderia aludir à observação da fotografia da mãe morta pelo sujeito saudoso, que procura novamente alguma espécie de comunhão com essa figura ausente, mesmo que somente através de um ritmo pressentido: "o corpo é formosura / urgente de ser rio: / ao meu encontro voa", no ambiente ao redor: "Numa paisagem de água, / tranquilamente, / estendes os teus ramos". Se "Retrato" registrava o "rosto semeado de melancolia" da mãe em vida, sua imagem agora é vista de outra maneira, "desprendida/ de inumeráveis, melancólicos muros": a morte é aqui encarada como libertação. "Nada" "dói”, "fere” ou 
“ofende”. Nas “águas" da poesia, o sujeito sente-se reencontrado com a "mãe”: “já nada nos separa".

Conforme discorre Óscar Lopes, a "água", além de participar da "fonte" e evocar a "fluida mobilidade das forças vitais" na poesia eugeniana, também desponta como elemento diluidor, em "descida ao nível zero da vida e da sensibilidade consciente" (LOPES, 2001, p. 97). A "água" mimetiza a "lenta diluição dos ritmos vegetais e minerais" (LOPES, 2001, p. 124), até a impossibilidade de diferenciação da matéria, à total transparência e fluidez: "grau minimal de consciência", "tempo nu" (LOPES, 2001, p. 145). Nesse fluir tranquilo e sem dor, encontram-se o sujeito e a mãe: os "dedos" alcançam o "rosto"; as "mãos" finalmente se entrelaçam: "Na tua mão me levas, / uma vez mais, ao bosque onde me sento / à tua sombra".

No "Coração do dia" - totalidade que admite abertura, transformação e mobilidade -, as vozes da consciência doída do sujeito se calam no fluir da "água". O "rio" avança ("ao meu encontro voa") para além do tempo vivido como progressão irreparável. As águas unem agora o que o tempo separava. As "almas" se encontram. Temos a sensação de refração do tempo, principalmente por meio da entrada à imagem atemporal do "bosque", onde se sentam mãe e filho.

$\mathrm{Na}$ penúltima estrofe, a fala da mãe, "Como tu cresceste", ecoa versos de "Poema à mãe", de Os amantes sem dinheiro, em que o tempo impunha a separação irremediável entre a mãe viva e o filho que "crescia": "Mas tu esqueceste muita coisa!/ Esqueceste que as minhas pernas cresceram, que todo o meu corpo cresceu"; e "Eu saí da moldura, dei às aves os meus olhos a beber" (ANDRADE, 1966, p. 82). O gesto das "aves" desprendia o sujeito da fixidez da imagem do "retrato" que a mãe guardara do filho. A poética eugeniana anunciava a expansão e o fluir como valores a serem perseguidos.

No presente poema, o "retrato" já não apresenta a ameaça de fixidez. A mãe se libertou das garras do tempo, e o sujeito procura na "água" a mesma mobilidade, permitindo um regresso à matriz materna, livre agora dos "muros" ou da "moldura" de outrora. Desse modo, diferentemente do poema de Os amantes sem dinheiro, a mãe é agora a primeira a reconhecer que o filho cresceu. E o sujeito também pressente o cessar do tempo linear e evolutivo: 
Alma: como eu cresci!

E como tu és,

agora,

pequena, frágil, orvalhada. ${ }^{246}$

A expressão "agora", isolada no meio da estrofe, se destaca, visualmente, das demais palavras, associando-se imediatamente a "Alma" pela posição no verso e pela repetição das vogais abertas. A vogal "a" 247 , ao enlear "agora" a "alma", estabelecendo certa comunicação semântica entre os termos, poderia evocar a sensação de presente absoluto que vivenciamos também no elemento "água” (água-texto; água-música): "alma orvalhada".

Enquanto fundamento primeiro, a "água" simboliza a origem da vida, bem como a dissolução e a morte. Como o "fogo", é um elemento ambivalente, podendo gerar a vida, mantê-la ou destruí-la. Em permanente fluir, a "água" associa-se à ideia de transformação e purificação. O nascimento da "água" é constante. Segundo discorre Bachelard, a união contínua das imagens da água põe o "universo em movimento", enquadrando, gradualmente, o "narcisismo do ser individual [...] num verdadeiro narcisismo cósmico" (BACHELARD, 2002, p. 12):

Desaparecer na água profunda ou desaparecer num horizonte longínquo, associar-se à profundidade ou à infinidade, tal é o destino humano que extrai sua imagem do destino das águas.

(BACHELARD, 2002, p. 14)

A “água” espelha a contínua busca humana pela própria imagem, sempre móvel e transcendente. Em sua infinitude e profundidade, é também linguagem em movimento. Como elemento metapoético, constitui uma verdadeira sintaxe do fluir na obra eugeniana. Desde o primeiro livro da coletânea, em que a "fonte" crescia no silêncio (1966, p. 48), fazendo coincidir sua "voz" com o correr do "sangue" do sujeito

\footnotetext{
${ }^{246}$ Comparamos essa imagem da "alma frágil e orvalhada" aos versos de "Mar, mar e mar" de As palavras interditas: "O mar volta a ser pequeno e meu, anêmona perfeita, repetida" (ANDRADE, 1966, p. 122). Em ambas as imagens, dá-se uma radical refração do tempo. Temos a sensação de totalidade, que, mesmo pressentida em movimento, como no "coração da cereja", de As mãos e os frutos, não se dissipa. O instante pode ser apreendido como unidade, como substância do "ser". Embora habitante do tempo e do espaço em constante movimento, o homem pode ser a consciência de "algo mais que passagem" - para utilizar a expressão de Octavio Paz (PAZ, 1982, p. 15).

247 "A é a letra inicial do poema universal. É a letra do descanso da alma na mística tibetana" (BACHELARD, 2002, p. 237).
} 
(1966, p. 47) e erguendo o "canto" como um "rio" caudaloso (1966, p. 18), a "água" simboliza um regresso à origem e à inspiração materna, mas também significa a vontade de se desprender das imagens fixas da infância. Na "errância líquida"248, a poética eugeniana pretende acompanhar e superar o fluir temporal. No elemento arcaico da "água", encontram-se tanto as possibilidades de expansão quanto de dissolução. Como acontece também com os outros signos recorrentes, na "água" reside o gesto de recomeço. No seu fluir metafórico, procura-se a libertação da imaginação das amarras do discurso, do encadeamento lógico, da vivência histórica e temporal. Pretende-se reverter, assim, o sentido usual.

Porém, desde As mãos e os frutos, livro em que a "água" "corre" em abundância (ora no ímpeto inicial da "fonte", citada em oito poemas, ora no fluir caudaloso do "rio", que aparece nove vezes), já está presente a ameaça da secura ("fonte onde a água já não passa" - 1966, p. 44); e a angústia diante da "impetuosidade" do "rio" cujo destino nem sempre é controlado ou desejado: "cavalo indomável como um rio" (1966, p. 34); "onde me levas, rio que cantei, [...] não quero que conduzas ao silêncio de uma noite maior e mais completa" (1966, p. 49).

No segundo livro, Os amantes sem dinheiro, a "água" aparece mais associada à melancolia de águas lentas ou paradas, ou a "lágrimas", "outono", "mar de insônia" (1966, p. 87): “não há nada que me peça água" (1966, p. 93); "lentos como a água", “cansados de esperar" (1966, p. 78); "gaivotas não as havia/ e o mar tinha secado" (1966, p. 67). Conforme analisamos em "Poema à mãe", o sujeito tenta, neste livro, desvincular o fazer poético da inspiração materna, já um tanto viciada. Assim, a "água" estagnada ou melancólica aponta também para essa direção.

Em As palavras interditas, a "água" é elemento sempre presente no cenário noturno em que "navios flutuam", "partindo no vento" e "regressando nos rios", e em que as "crianças" caminham de costas para o "mar" (1966, p. 98). Essas águas noturnas são mais violentas do que nos livros anteriores, podendo ser denominadas "tempestade" (1966, p. 100), em que "barcos" "naufragam" (1966, pp. 116 e 117), "rostos" se "afogam" (1966, pp. 106 e 117), e onde submerge o corpo de um "adolescente morto" (1966, p. 121). Ou, ainda, "lágrima": "gota de orvalho secretamente morta na tua mão" (1966, p. 103). No entanto, é nesse mesmo livro também que, por sua vez, a procura

\footnotetext{
${ }^{248}$ Expressão de Carlos Mendes de Sousa: “[...] Na fluidez de um universo cujos limites são os não limites, a metáfora como que arrasta, aglutinando nas suas águas, para além do metaforizado desejo, outras referências nucleares: a referência materna e a própria referência poética” (SOUSA, 1992, p. 91).
} 
pelas águas, cujo correr em As mãos e os frutos se dava de modo mais "natural" e abundante, volta a ser articulada: "até que uma fonte rasgue a tua boca / e a noite fique transbordante de água" (1966, p. 105). O corpo do amado é então referido por "mar perfeito" (1966, p. 100), "mar azul de ser tão branco" (1966, p. 101). Encontramos neste livro também, pela primeira vez em Poemas, um longo poema sobre o "mar", já analisado na terceira seção deste capítulo. Nele, se pergunta o que é o "mar", e entre as respostas, misturam-se referências diversas: "corpo do amado", "música distante", "asa", "brancura", "sangue", "mãe” (1966, p. 120).

Em Até amanhã, o "mar" também é aludido como horizonte desejado: "veias abertas gritando pelo mar / [...] quero apenas essa voz, afogar-me nesse rio" (1966, p. 148), e "É urgente um barco no mar" (1966, p. 139), linha que será retomada, de maneira ainda mais central, em Coração do dia - embora o "mar" apareça em apenas três poemas, contra nove referências gerais à "água" corrente, principalmente na figura do "rio", ou em verbos que com ele mantêm certa contiguidade semântica, como "inundar" ou "derramar".

Ou seja, neste quinto livro da coletânea, a "água" assume o estatuto de um destino. Ela é o signo que encaminha, dentro da poética eugeniana, à indagação radical pelo interlocutor, ao anseio pelo encontro e pela união materna. A "água" metaforiza o cantar eugeniano: "música” distante, "secreta voz da água” (1966, p. 145), "rumor”, "fugitiva voz da água entre o azul” (1966, p. 113). Mimetiza, por isso, o "murmúrio" que rompe com o "silêncio" estéril, mas que, paradoxalmente, reconduz também a um "silêncio" ulterior, relacionado, talvez, à vivência do inefável, e do primordial. Aqui, recorremos à visão ontológica de Eduardo Lourenço sobre a palavra poética, crítico que muito se debruçou sobre a relação difícil entre música e silêncio na poesia eugeniana:

Sempre os poetas encerraram nos poemas o mistério, para eles, claro, que, de fora, nós chamamos poesia. Toda a grande poesia integra como sombra ou luz paradoxalmente excessiva a sua poética. Imemorialmente, na nossa tradição ocidental, os deuses ou as mais familiares Musas, com as suas vocações codificadas, recebiam as primícias de um saber poético que não ousava ainda imaginar-se como criador de um mundo a partir de nada, como de Deus se diz. Como poesia moderna - nem a Modernidade é outra coisa - , o poeta separase da musa ou como Pessoa o temeu, a Musa recolheu ao seu silêncio pela poesia mesma ofuscada. De tal modo que a poesia outro mais enigmático fim não prossegue que o de dar corpo a esse silêncio, em que enraíza toda palavra de onde a antiga luz dos deuses ou o reflexo da Musa se retiraram. Sem Deus e sem musa, a palavra poética 
moderna - moderna pela consciência dessa ausência - é uma exploração intérmina desse silêncio coessencial a um verbo onde o ser - o do mundo, dos outros, o nosso - devia ser dito ou apreendido em todo o seu esplendor e misteriosamente nos escapa.

(LOURENÇO, 2007, p. 31)

Por meio da movimentação constante entre os signos, a poética eugeniana persegue o mesmo gesto de recomeço: "silêncio" que, por um lado, evoca a distância dolorosa entre palavra e mundo, mas que, por outro, mimetiza também a refração do tempo e o alargamento da percepção do instante poético, rompendo com espaços em que se pode experimentar, no encontro sempre renovado das imagens, novas relações de identificação. Se, como temos visto, o projeto eugeniano de reversão do tempo e do discurso históricos venha acompanhado de angústia e medo de que o "silêncio" procurado se dissipe no vazio ${ }^{249}$, o último poema de Coração do dia reafirma a vontade de encontro, num gesto talvez mais inspirado do que temeroso:

\section{Despertar}

É um pássaro, é uma rosa, é o mar que me acorda? Pássaro ou rosa ou mar, tudo é ardor, tudo é amor. Acordar é ser rosa na rosa, canto na ave, água no mar.

(ANDRADE, 1966, p. 171)

Por meio da enumeração de signos recorrentes e metapoéticos, como "rosa" "pássaro" e "mar", o poema narra uma reconciliação: dá-se a tão perseguida fusão da palavra com o mundo, "rosa na rosa", "canto na ave", "água no mar". No seio do instante presente pode a poesia eugeniana realizar o "despertar", possibilitando o encontro do sujeito com a mãe ("rosa na rosa"), a expansão crescente ("canto na ave"), até o fluir contínuo (“água") para a imagem arquetípica e primordial do "mar": ponto

\footnotetext{
${ }^{249}$ De modo bastante sugestivo para a nossa análise, Susan Stewart, ao tratar da função demiúrgica da poesia (já referida na nota 1), definindo as formas poéticas como uma resposta, ou um enfrentamento do vazio aniquilador da "escuridão da noite", explica que, por outro lado, "The poet's tragedy lies in the fading of the referent in time, in the impermanence of whatever is grasped" (STEWART, 2002, p. 2). Essa afirmação é bastante pertinente para se compreender a angústia eugeniana, sempre reincidente em Poemas, bem como o lamento dirigido à "noite" e à impermanência da palavra poética.
} 
onde se dá a expansão do ser, eterno recomeço, onde a palavra pode enfim cantar o silêncio.

\title{
3.7 Um "Mar" de silêncio
}

\author{
Que branca mão devagar \\ quebra os ramos do silêncio? \\ (Eugénio de Andrade, 1966, p. 180) \\ Oh tão azul o mar na tua mão! \\ (Eugénio de Andrade, 1966, p. 196) \\ escreve \\ a tinta se esvai \\ o mar se expande \\ (Seferis, 1997, p. 72) $)^{250}$
}

Em Coração do dia, a "água" se torna, como vimos, o signo norteador da poética eugeniana: conduz a indagação radical pelo interlocutor, se oferece como elemento estruturador e metalinguístico. Seu fluir rítmico-metafórico rompe com o silêncio - ainda que no silêncio encontre também uma dada "música" primordial, vivência do indizível ${ }^{251}$. Na diluição da "água" cessa a vigília, esvaziam-se os significados mais cristalizados. O sujeito pode então "Despertar", como no último poema do livro, para a fusão luminosa entre palavra e mundo: "acordar é ser rosa na rosa, canto na ave, água no mar". Eis a enumeração metapoética ${ }^{252}$ de alguns dos signos mais recorrentes nessa poesia, cuja permuta, poema a poema ou livro a livro, mantém em movimento a imensa energia afetiva. ${ }^{253}$

\footnotetext{
${ }^{250}$ Poema citado em "A trilha errante do Haikai”, de Alberto Marsicano. Pósfácio de Trilha estreita ao confim. Basho. São Paulo: Editora Iluminuras, 1997.

${ }^{251}$ Sobre a relação entre "silêncio" e "música" na poesia eugeniana, Eduardo Lourenço discorre: "Creio que aprendeu isso da música que é silêncio ouvido. Sempre pensou que o não-dito era mais importante do que o expresso. [...] Tudo nele foram sempre "afluentes" desse silêncio que o esplendor das coisas naturais revela tanto quanto esconde". Eduardo Lourenço. Paraíso sem mediação - breves ensaios sobre Eugénio de Andrade. 2007, p. 51. De acordo também com José Tolentino de Mendonça, a palavra de Eugénio é problematizada como "resíduo do silêncio", como "alusão encravada no esplendor do silêncio", em "A narrativa do silêncio em Eugénio de Andrade". Ensaio sobre Eugénio de Andrade. Porto: Edições Asa, 2003, pp. 226 e 227. Assim, música e silêncio se aproximam em sua poesia: "Música não é só especialidade artística como a tornamos, mas o latejar da vida, sua pulsão intrínseca, e o silêncio dessa poesia devolve-nos a graça, a verdade desse dizer" (MENDONÇA, 2003, p. 227).

${ }^{252}$ Para a poesia eugeniana, os termos "metapoesia" ou "metalinguagem" talvez sejam inapropriados, já que raramente encontramos, nessa obra, um poema que se dedique a somente discutir explicitamente sua feitura. Geralmente, o tema da palavra é apresentado em condição de coincidência com outros temas e afetos, principalmente aqueles relacionados ao amor.

${ }^{253}$ Estes signos são investidos de grande "carga afectiva", como reconhece Luís Miguel Nava, em $O$
} 
Desse modo, a expressão "água no mar", do último verso de Coração do dia, poderia, dentro de uma leitura mais global como a que ora fazemos, prenunciar um dos traços mais recorrentes da escrita eugeniana em Mar de setembro (1959- 1963): a procura pelo "mar", imagem arquetípica, origem, expansão do ser. O desaguar no "mar", signo central presente desde o título, é uma constante neste livro: gesto que permite grande concentração imagética, em que se experimenta a sensação de refração e simultaneidade.

Como fundamento primeiro, retorno e diluição ao elemento arcaico, o "mar" providencia nascimento contínuo. Seu ritmo constante "beira o silêncio absoluto"254, instalando a indissociação geral entre ir e vir, fim e começo, nascimento e morte, música e silêncio. Como grau minimal em agitação permanente, o "mar" trabalha a duração e a intensidade.

Assim, logo no poema de abertura, cujo título repete o do livro, encontramos já manifestada a tentativa predominante de repouso na imagem; refração ou condensação de um instante luminoso, reunido na figura do "mar": espécie de termo de chegada, para onde deságua o correr e os destinos desta arte poética.

\section{Mar de setembro:}

Tudo era claro: céu, lábios, areias. O mar estava perto, fremente de espumas. Corpos ou ondas: iam, vinham, iam, dóceis, leves, só alma e brancura. Felizes, cantam; serenos, dormem; despertos, amam, exaltam o silêncio. Tudo era claro, jovem, alado. O mar estava perto, puríssimo, doirado.

essencial sobre Eugénio de Andrade (Maia: Casa da Moeda, 1987, p. 22): "Na poesia de Eugénio de Andrade, surgem com frequência algumas palavras a que, à falta de melhor termo, poderíamos chamar 'signos carregados', dado que parecem transportar em si uma forte carga, geralmente positiva, que lhes confere um estatuto especial e lhes permite ocuparem, em determinadas circunstâncias, o lugar de outras"

${ }^{254}$ Expressão de Óscar Lopes, ao se referir ao elemento diluidor da "água" na poesia eugeniana: "mínimo possível de consciência individual”, "poesia à beira do silêncio absoluto" (LOPES, 2001, p. 125). 
Bem como no primeiro poema dedicado ao "mar" na coletânea Poemas, "Mar, mar e mar", de As palavras interditas, as "ondas" do mar aqui se misturam às referências ao "corpo" do amado. ${ }^{255}$ A paisagem marítima compõe-se não só de "céu" e “areias", mas também de "lábios"; e o ritmo do ir e vir do mar é também erótico: "iam, vinham, iam", "fremente de espumas". O "mar" aparece, assim, como horizonte de realização do desejo: "O mar estava perto, / puríssimo, doirado". Em diversos poemas adiante, serão traçadas equivalências entre "mar" (ou componentes da paisagem marítima) e "corpo": "inunda os lábios de oiro" (1966, p. 176); "uns lábios de brisa e água" (1966, p. 180); "Agora /onde te despes /é verão" e "o que o teu corpo tem / de concha / molhada" (1966, p. 181); "do teu corpo nu, [...] / no azul secreto / da concha das pernas” (1966, p. 182); e “Que rompam as águas: / é de um corpo que falo!” (1966, p. 191) - relação metonímica que poderia evocar também a Vênus, como representada por Botticelli, a nascer de uma concha sobre o $\operatorname{mar}^{256}$.

O "mar" estabelece equivalências dentro da relação amorosa; coincide com o "corpo" - e o tempo do corpo é o tempo do presente, do instante alargado, da vivência dos encontros: espaço onde "tudo acolhe / e afaga", como neste verso do sétimo poema do livro, "Madrigal" (1966, p. 181). Entre o "ir" e "vir" do "mar" confluem "corpos", “ondas", "lábios”, “areias”. Percebe-se a sobreposição dos vários níveis do real, em que os amantes "dormem" ao mesmo tempo que estão "despertos"; “cantam" e também "exaltam o silêncio". A alternância dos tempos verbais entre "iam, vinham, iam", no pretérito imperfeito, e "Felizes cantam / serenos dormem," no presente, indica a confluência e acumulação também dos diversos tempos e experiências vividos pelo corpo. Desse modo, o "mar" é espaço de reminiscências, mas convoca também as sensações corporais mais instantâneas, acarretando a justaposição dos planos espaciais e temporais.

O ritmo, distribuído entre versos curtos, que se alternam entre cinco, seis e, em alguns momentos, sete sílabas, evoca a brevidade do instante. A métrica mais ou menos

\footnotetext{
${ }^{255}$ Naquele poema, no entanto, o "mar" participa de um ambiente de tristeza e desolação; ao passo que, neste, compõe uma paisagem de plenitude, calma, carícia.

${ }^{256}$ Referência à representação da Vênus por Sandro Botticelli (1485). Deusa do amor e da beleza, a Vênus nasceu, em uma de suas vertentes míticas, das ondas e da espuma do mar originárias do esperma do Deus do Tempo, Cronos. Cf. Pierre Grimal. Dicionário da Mitologia Grega e Romana. Rio de Janeiro: Bertrand Brasil, 1997, p. 10.
} 
regular, alinhada em versos como "iam, vinham, iam"; “corpos ou ondas", ou "dóceis, leves, só", em que as sílabas tônicas e átonas se alternam de modo simétrico, mimetiza o balanço do mar e o repouso "vibrante" nessa imagem acolhedora, a equilibrar jogos de oposições semânticas e reflexos. A sensação é de grande reversibilidade.

Alguns recursos sonoros, como a repetição de "am" no já citado "iam, vinham, iam", ou de "m" em "fremente de espumas", parecem mimetizar o movimento das ondas, tanto em seu ponto de formação quanto no momento de refluxo, sugerido pela aliteração sibilante em "dóceis, leves, só", e "puríssimo". A predominância de vogais também poderia sugerir a doçura deste mar pouco violento, cuja "espuma", "ondas", "areias" antes acolhem e acariciam.

Outro elemento que chama a atenção nesse poema de abertura, e que será também bastante recorrente no transcorrer de todo o livro, sempre presente nas paisagens marítimas, é a "luz": "Tudo era claro", "brancura", “doirado". Esse signo aparece sob diversas formas em oitenta e cinco por cento dos poemas (em dezoito, de um total de vinte e um), reunindo-se na figura do "oiro", do "verão", do "sol", do "dia". A “manhã" é a parte do dia mais evocada, e a leitura percorrida dos poemas poderia darnos a sensação (com algumas exceções) de que tudo se passa no termo de apenas um dia: instante alargado à beira do mar de uma "manhã" lenta, ("A terra me sabes, / à luz das manhãs" (1966, p. 182); "Que ronda matinal, / que luz tão jovem” (1966, p. 185); “Eras tu? Era o dia / acabado de nascer?" (1966, p. 187); “É um dia de sol / perto do mar” (1966, p. 188); “[...] Azul bilbau, / quando amanhece” (1966, p. 197)); ou ainda no percurso de uma tarde luminosa ("oiro da tarde" - 1966, p. 199), a se desprender de um verão longo e inesquecível, mas que chega já ao fim, como propõe o título do livro, por meio da referência ao mês de "setembro" no hemisfério norte.

Em Poetry of the senses, Susan Stewart identifica na "luz" um dos grandes emblemas da escrita poética, sob o argumento de que toda poesia se faz, estruturalmente, da luta humana contra o oblívio e contra as "trevas". Segundo a autora, a escuridão nos apavora nem tanto pelo medo da morte ou da eminência do perigo:

Not as an expansion, but rather as a contraction, of whatever the mind can hold as an image of the human. It is unbearable, this loneliness of the mind working on its own to maintain the outline, the figure, of the person. Frozen, voiceless, a prisoner without sentence, the mind in the dark has no object to reflect on and no object to limit the endless racing of its reflections. In the end, the fear of the darkness is the fear 
that the darkness will not end. It will be the argument of this book that the cultural, or form-giving work of poetry is to counter the oblivion of darkness. ${ }^{257}$

Capaz de atuar na relação conflituosa entre existência individual e social, a poesia se oferece como resistência à evanescência e à escuridão. Ao criar onde antes era o nada, a poesia instaura o espaço e o tempo humanos. Nesse contexto, toda palavra poética é luminosa, mesmo quando a "luz" se manifesta precária ou fragmentária perante uma noite mais vasta. Nessa mesma linha, segundo ainda a autora, a grande tragédia da atividade poética jaz na ameaça, sempre constante, do desaparecimento do referente no tempo, da impermanência de qualquer coisa encontrada. ${ }^{258}$

No trabalho reflexivo da poesia eugeniana a "luz" é constantemente explicitada. Do mesmo modo, o "mar" é signo emblemático: força-forma a atuar contra o esquecimento, contra a passagem do tempo. O "mar" é sinédoque perfeita para o silêncio absoluto aspirado pela poesia eugeniana. É sinédoque do espaço abrangente do poema, que se pretende total, onde tudo conflui e o instante se concentra.

Desde As palavras interditas, o "mar" sugeria o espaço incerto do poema, a brancura da página, o rumor, o silêncio anterior e posterior à escrita. De todos os signos recorrentes observados em Poemas, talvez seja o "mar" o signo mais emblemático. Primeiro, porque, com ele, quase todos os signos analisados parecem manter certa proximidade: a "ave" em Os amantes sem dinheiro sobrevoava o "mar" em diversos poemas. O "barco", em As palavras interditas, também admite uma leitura que se relaciona, metonimicamente, com este signo; assim como a "água", e agora também a "luz", sempre presente na descrição das paisagens marítimas. ${ }^{259}$

\footnotetext{
257 “Não como uma expansão, mas antes como uma contração daquilo que a mente mantém como imagem do humano. É insuportável essa solidão da mente a trabalhar sozinha, para manter a forma, a figura da pessoa. Congelada, muda, uma prisioneira sem sentença, a mente no escuro não tem nenhum objeto no qual possa se refletir, e nenhum objeto para limitar a corrida infinita de suas inquietações. No final, o medo da escuridão nada mais é do que o medo de que a escuridão não vá mais acabar. O argumento deste livro é o de que o trabalho cultural e enformador da poesia pretende opor-se ao oblívio e à escuridão." Susan Stewart. Poetry and the fate of the senses. Chicago: The University of Chicago, 2002, p. 1. Tradução nossa.

258 "The poet's tragedy lies in the fading of the referent in time, in the impermanence of whatever is grasped. The poet's recompense is the production of a form that enters into the transforming life of language" (STEWART, 2002, p. 2).

${ }^{259}$ Inserida em um jogo complexo de metamorfoses, Óscar Lopes cita a junção entre os elementos "água", "corpo" e "terra", frequente na poesia eugeniana: "O desejo também confere a um corpo a fluência da água e a fluência irreversível, indiretamente medida em tempo, de um rio corrente" (LOPES, 2001, p. 117). Como vimos em As palavras interditas, a imagem do corpo do amado aparece frequentemente ligada ao mar e às ondas.
} 
Em segundo lugar, em seu ir e vir infinito, o "mar" poderia mimetizar os movimentos conflituosos da poética eugeniana ${ }^{260}$ : errante, a permutar os signos ad infinitum, num mover sem cessar que vai transformando a substância do ser. Para essa poesia, a vida toda é imóvel e o instante luminoso só pode ser capturado, como pura presença, em movimento e metamorfose. Mas também se assumindo como termo de chegada e horizonte do desejo; como ponto de expansão e rarefação total da linguagem, o "mar" também desperta a consciência do grande vazio em que o homem navega, sem saber para onde veio e vai.

No décimo poema do livro, "Canção escrita nas areias de Laga", temos, mais uma vez, a descrição demorada de um ambiente marítimo, mesclado ao corpo do amado:

\section{Canção escrita nas areias de Laga}

No teu ombro respiro.

Belos são os navios,

altos, estreitos.

Feliz, o teu rosto no meu.

Que luz sobre o teu peito!

No teu ombro respiro.

Belas são as areias,

fulvas de verão.

Feliz, o meu rosto no teu.

Oh tão azul o mar na tua mão!

(ANDRADE, 1966, p. 196)

Em "As palavras interditas", poema de abertura do terceiro livro, o "navio" flutuava levando o "rosto" do amado encostado ao "rosto do navio"; e na "areia branca", uma "criança" passava "de costas para o mar". Os referentes dispersavam-se. No presente poema, ao contrário, os componentes se encontram. Há uma junção total e orgânica entre o "eu", o outro, a escrita, o verão, reforçada pela estrutura paralelística: "Feliz, o teu rosto no meu", "Feliz, o meu rosto no teu". E também em "luz sobre o teu peito"; "tão azul o mar na tua mão!" Através de um jogo simétrico de reflexos e relações, o "rosto", o "peito" e a "mão" do amado espelham a paisagem marítima e o

\footnotetext{
${ }^{260}$ Carlos Mendes, sobre o "mar" na poesia eugeniana, escreve: "As vagas, a ondulação perpetuam a imagem do movimento constante, visão que admiravelmente tende a figurar a pulsão errática do desejo [...]. A intermitência do ir e vir, os contornos fluidos projectam a figuração do nomadismo, da não fixação, do espraiamento" (MENDES, 1992, p. 103).
} 
sujeito eugeniano. Tudo participa de tudo. Temos, portanto, que os elementos da paisagem e do corpo humano se alternam e interseccionam relações analógicas, em que se experimenta a simultaneidade do tempo da escrita.

Do mesmo modo, caminha o terceiro poema do livro, "Quase nada", que também dialoga com "As palavras interditas":

\section{Quase nada}

Passo e amo e ardo.

Água? Brisa? Luz?

Não sei. E tenho pressa:

levo comigo uma criança

que nunca viu o mar.

(ANDRADE, 1966, p. 177)

Este poema poderia compor uma súmula dos movimentos e tensões principais da arte poética eugeniana: de passagem, no amor e no desejo ("amo e ardo"), na permuta entre os signos, na estreita ligação com as substâncias elementais ("Água", "Brisa” (ar), "Luz" (fogo)); o poeta passa, hesita ("Não sei”), "tropeça", como diria em outro lugar, mas tem pressa e urgência em levar "uma criança que nunca viu o mar". Se antes, a "criança" caminhava de costas para o "mar", como vimos em "As palavras interditas", o poeta agora declara trabalhar em favor do encontro desses mesmos referentes, ressaltados também pela continuidade sonora entre as vogais no primeiro verso do poema, em que as sílabas finais de cada verbo se misturam às sílabas iniciais dos verbos seguintes, criando o efeito de fluidez e continuidade. ${ }^{261}$

O ritmo, composto por versos breves, também colabora com o correr apressado das palavras no poema, cujo termo final vem dar em "mar" - imagem derradeira, termo

\footnotetext{
${ }^{261}$ A análise pormenorizada da sonoridade desse verso é mote central do artigo "Do fogo descer à neve com Eugénio de Andrade". Virgínia Boechat. Org. Ida Alves; Luis Maffei. Poetas que interessam mais: estudos sobre poesia portuguesa contemporânea. Rio de Janeiro: Azougue / FAPERJ, 2011, p. 12. "Tal redondilha menor traz três verbos coordenados numa sintaxe construída em reiteração da partícula de adição, ligados a ponto de estarem quase interpenetrados sonoramente, depostos no verso numa cadeia cíclica de revezamento entre as mesmas vogais, em mesma sequência, o que o torna extremamente musical, naquilo que poderia também ser a reprodução do movimento das rodas de um trem encarrilhado de maneira perfeita, cíclica, simétrica, comedida e equilibrada. Semanticamente simples e amplo, o que resulta numa aparente limpidez, passar, amar e arder encontram-se numa primeira pessoa do singular, um sujeito de quem com tão pouco recurso já é possível deduzir que tem corpo com sensações, desejo, sentimento amoroso, deslocamento em diferentes espaços, assim como o tempo perceptível e conscientemente contado. É um verso que, sem dúvida, em variados níveis, diz muito sobre a vasta obra poética em que se insere."
} 
de chegada, horizonte aspirado, abertura. O "mar", como último vocábulo do poema, desperta o desejo de expansão, transcendência do ser, como também nos versos do oitavo poema, "À tua sombra”: “[...] Apetece cantar/ nos gomos, nas luas, / nas colinas breves / do teu corpo nu, / cantar ou correr / na água, na seiva [...] / no azul secreto / das conchas das pernas. / [...] Apetece morrer. / Morrer ou cantar.” (1966, p. 183) Assim, "cantar" implica "morrer": lançar-se para a frente, em direção ao encontro do "outro"; “correr" na "água" ou na "seiva"; desmanchar-se no horizonte marítimo, evocado por "concha", "azul secreto" e "dunas", em outra parte do poema.

O "mar" permite, por sua vez, a vivência e a aceitação da morte. Segundo Bachelard, toda "água” ensaia também um convite à morte: "É um convite a uma morte especial que nos permite penetrar num dos refúgios materiais elementares." (BACHELARD, 2002, p. 58). É desse modo, portanto, que a "água" nos impõe também o tema do silêncio: o murmúrio da água vai se debilitando gradualmente até o retorno da solenidade do silêncio originário.

Em seu ir e vir constante, o "mar" constitui espaço de confluências e imaginação aberta; possibilita a máxima entrega, até a completa transcendência do ser. Nesse sentido, poderia configurar também o espaço do poema - silêncio onde tudo começa.

Desde os primórdios da tradição lírica portuguesa, o “mar” é presença constante, e aparece, já nas cantigas trovadorescas galego-portuguesas, associado à saudade ${ }^{262}$, bem como ao anseio pela união sexual. O "mar" permanece, assim, como desejo do outro, como vontade de se entregar a vivências, lugares e perspectivas diversas, caracterizando-se, enfim, como potencial de transformação. ${ }^{263}$

Dessa maneira, no signo do "mar" reúnem-se os ímpetos e direções mais variados da poética eugeniana, a qual, neste livro, manifesta o projeto de revisão ou revisitação de sua poesia, como demonstra a leitura do poema "Espelho", décimo quinto do livro, reflexivo desde o título:

\footnotetext{
${ }^{262}$ Observar, por exemplo, o motivo do "mar" nesta cantiga de Martin Codax, "Ondas do mar de Vigo", escrita no século XIII: "Ondas do mar de Vigo, / se vistes meu amigo? / e ai Deus, se verrá cedo? / Ondas do mar levado, / se vistes meu amado? / e ai Deus, se verrá cedo? / Se vistes meu amigo, / o por que eu sospiro? / e ai Deus, se verrá cedo? / Se vistes meu amado, / o por que hei gram coidado? / e ai Deus, se verrá cedo? http://cantigas.fcsh.unl.pt/cantiga.asp?cdcant=1308\&pv=sim, acesso em 13/5/2012.

${ }^{263}$ Sobre o "mar" na poesia de Camilo Pessanha, outra grande influência para Eugénio de Andrade, António Falcão Rodrigues de Oliveira discorre: "Veículo e fim de seu próprio ser sugerindo o desfalecimento e a anulação do ser no infinito". O "mar" liga-se, portanto, ao tema da morte e da transformação. O simbolismo de Camilo Pessanha. Lisboa: Edições Ática, 1979, p. 57.
} 


\section{Espelho}

Que rompam as águas:

é de um corpo que falo!

Nunca tive outra pátria,

nem outro espelho,

nem outra casa.

É de um rio que falo,

desta margem onde soam ainda,

leves,

umas sandálias de oiro e de ternura.

Aqui moram as palavras;

as mais antigas,

as mais recentes:

mãe, árvore,

adro, amigo...

Aqui conheci o desejo

mais sombrio,

mais luminoso,

a boca

onde nasce o sol,

onde nasce a lua.

E sempre um corpo,

sempre um rio:

corpos ou ecos de colunas,

rios ou súbitas janelas

sobre dunas,

corpos,

dóceis, doirados montes de feno,

rios,

frágeis, frias, flores de cristal.

E tudo era água,

água,

desejo só

de um pequeno charco de luz.

De luz?

Que sabemos nós

dessas nuvens altas,

dessas agulhas

nuas

onde o silêncio se esconde?

Desses olhos redondos,

agudos de verão,

e tão azuis

como se fossem beijos?

Um corpo amei,

um corpo, um rio, 
um pequeno tigre de inocência,

com lágrimas

esquecidas nos ombros,

gritos

adormecidos nas pernas,

com extensas,

arrefecidas,

primaveras nas mãos.

Quem não amou

assim? Quem não amou?

Quem?

Quem não amou

está morto.

Piedade,

também eu sou mortal!

Piedade

por um lenço de linho

debruado de feroz melancolia,

por uma haste de espinheiro

atirada contra o muro,

por uma voz que tropeça

e não alcança os ramos.

De um corpo falei:

que rompam as águas!

(ANDRADE, 1966, p. 191)

Toda verdade poética aqui começa no corpo, onde se misturam as noções de desejo carnal, amor, palavra, água, mãe, amado, melancolia, luz, milagre, rio, poema.

Mais uma vez referido em termos de "águas", o poema mimetiza a densidade e o fluir autônomo da linguagem, cujo percurso metamórfico das imagens deixa entrever uma série de intertextos, como referências diretas a outras obras poéticas - por exemplo, "sandálias de oiro", motivo grego que aparece nos fragmentos de Safo ${ }^{264}$, , sempre

\footnotetext{
${ }^{264} \mathrm{O}$ próprio Eugénio de Andrade traduziu fragmentos dessa poetisa nascida na ilha grega de Lesbos, no século VII a.C. De sua obra, destruída pelos cristãos nos séculos IV e XI, sob a acusação de imoral, restaram apenas uma ode completa e cerca de duzentos fragmentos, dos quais setenta e cinco foram traduzidos por Eugénio de Andrade (vertidos de línguas modernas), publicados inicialmente em 1977 e depois revistos e incluídos na sua obra completa Poesia e prosa. vol. II. Lisboa: Limiar, 1990, pp. 10 a 29. No prefácio da tradução, Eugénio de Andrade declara o fascínio exercido por Safo sobre ele: "Não é a primeira vez que o afirmo: esta mulher é uma das minhas fascinações mais antigas. Não admira, portanto, que ao longo da vida tenha ido coleccionando traduções da sua obra. E um dia não resisti: meti-me também eu a traduzi-la. Traduzi-la é uma maneira de falar. O que aí está, dada a minha ignorância do grego, foi-me dado a ver por outros olhos: Reinach, Meunier, Pontani, Quasimodo, etc." Idem, p. 12. O fragmento traduzido por Eugénio em que "sandálias de oiro" aparece é o de $\mathrm{n}^{\circ} \mathrm{V}$ : "E de súbito / a madrugada de sandálias de oiro". Idem, p. 17.
} 
misturados a signos de sua própria poética, como "mãe, árvore, adro, amigo", em que "árvore" e "amigo" poderiam aludir à tradição das cantigas de amigo (cuja voz feminina a esperar pelo amado também é frequentemente assumida pelo sujeito poético eugeniano), ao passo que "mãe" e "adro" pertencem à cosmogonia poética eugeniana, como já vimos. Elementos da paisagem também mesclam a tradição clássica e a vivência moderna (e talvez pessoal), como "ecos de colunas" e "súbitas janelas / sobre dunas". Identificamos ainda alusões bíblicas na criação de um espaço genesíaco que se identifica com a "árvore” da vida. Os versos "Que rompam as águas/ é de um corpo que falo" relocam o sentido bíblico de "milagre", associado à travessia de Moisés, para o desejo carnal e a expressão verbal.

Como é bastante comum na poesia eugeniana, há também nesse poema a utilização de diversas facetas (embora transformadas) da estrutura paralelística, tal como aquelas praticadas pelos cantores medievais, encontradas principalmente nas cantigas de amigo, como as de Pero Meogo e Martin Codax. Eugénio emprega, com mais liberdade, o recurso do leixa-pren na virada da primeira para a segunda estrofe, ao retomar o verso "é de um corpo que falo" com uma pequena variação: “é de um rio que falo". E na quinta estrofe (grifo nosso):

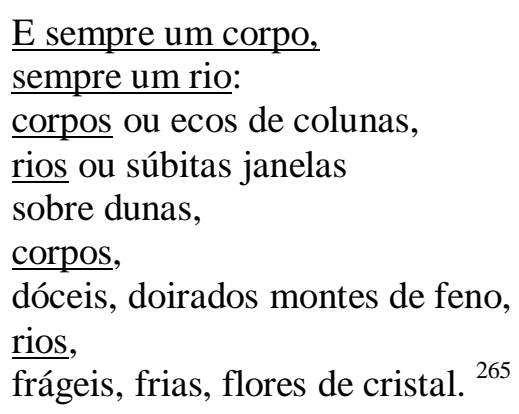

O segundo verso repete o primeiro, substituindo, mais uma vez, "corpo" por "rio". Ao longo da estrofe, o poeta alterna as substituições paralelas a fim de estabelecer a comparação direta entre os dois termos. Há ainda a presença de perguntas, principalmente na nona estrofe, "Quem não amou / assim? Quem não amou? / Quem? / Quem não amou / está morto", que ecoa o molde reduplicado de afirmação $\rightarrow$ pergunta / afirmação $\rightarrow$ pergunta das kharjas antigas, cantigas escritas em moçárabe no tempo da

\footnotetext{
${ }^{265}$ O mesmo ocorre na virada da sexta estrofe, que termina com o verso "de um pequeno charco de luz", para a sétima estrofe, que começa com "De luz?".
} 
conquista da Península Ibérica pelos árabes ${ }^{266}$, as quais muito influenciaram as cantigas de amigo. Nas kharjas, cada pergunta advém da afirmação precedente, numa espécie de paralelismo com causa e efeito no significado, conforme explica Stephen Reckert ${ }^{267}$ : "Este vaivém entre a lógica causal e a pura emoção das perguntas paralelas reflete com acuidade os sentimentos de desorientação e angústia” (RECKERT, 1999, p. 40), expressos, muitas vezes, por um eu lírico feminino que lamenta a ausência de um amigo. No caso do poema acima, as perguntas paralelísticas também expressam o contraste de emoções experimentadas pelo sujeito quanto ao fluir arrebatador de seu próprio desejo, comparado a um caudaloso "rio". O sujeito diz amar com intensidade e pede ao leitor "piedade" talvez pela premência do relato, às vezes permeado de melancolia.

O leitor acostumado à poesia de Eugénio de Andrade pode reconhecer ainda expressões dialogantes ou trechos retirados de poemas anteriores, e certas afirmações que trazem à baila a problemática central de sua poética, definida pela movimentação dialética em torno da tentativa de religação da palavra com o mundo: ora afirmada com êxtase, ora negada criticamente, através da expressão trágica e, por vezes, também melancólica.

De luz?

Que sabemos nós dessas nuvens altas, dessas agulhas

nuas onde o silêncio se esconde?

“Agulhas" e "silêncio" recuperam o poema "Espera", de As mãos e os frutos ${ }^{268}$, em que o sujeito lamentava a angústia, o silêncio estéril circundante e o ímpeto, por vezes frustrado, da palavra poética. Naquele poema, como neste trecho, está presente a vontade ascensional da poesia eugeniana, e o anseio de religação com o todo, pressentido, também, na própria evocação do silêncio, sempre ambígua.

\footnotetext{
${ }^{266}$ Essas formas poéticas foram criadas e desenvolvidas na Espanha mulçumana dos séculos XI e XII.

${ }^{267}$ Em Para além das neblinas de novembro - perspectivas sobre a poesia ocidental e oriental. Lisboa: Fundação Calouste Gulbenkian, 1999.

268،“Aqui onde o exílio / dói como agulhas fundas, / esperarei por ti / até que todas as coisas sejam mudas. // Até que uma pedra irrompa / E floresça. / Até que um pássaro me saia da garganta / E no silêncio / desapareça" (ANDRADE, 1966, p. 50).
} 
Da mesma maneira, as comparações se sucedem, em que uma imagem "espelha" a outra, como sugere o título, entre "corpo", "rio", "charco de luz", "pequeno tigre de inocência" - que nos remete ao poema "Retrato", de Até amanhã, etc. Nessas palavras, ainda que fluidas, "leves” como "ecos"; “súbitas”, “frágeis”, “desejo só/ de um pequeno charco de luz", pode o sujeito encontrar sua única "pátria”, "espelho", "casa" três signos que se associam à construção da identidade. O sujeito se define, desse modo, através da linguagem poética, assente, sobretudo, na relação íntima com o corpo.

No entanto, a despeito do projeto geral eugeniano de fazer transcorrer uma linguagem autônoma que "apague" as marcas do sujeito, em momentos dramáticos, como na penúltima estrofe do poema, encontramos rasgos íntimos, expressões de estados melancólicos, em tom lamentoso que nos faz lembrar, em alguns momentos, a poesia de Camilo Pessanha ${ }^{269}$ :

\author{
Piedade, também eu \\ sou mortal! \\ Piedade \\ por um lenço de linho \\ debruado de feroz melancolia, \\ por uma haste de espinheiro \\ atirada contra o muro, \\ por uma voz que tropeça \\ e não alcança os ramos.
}

(ANDRADE, 1966, p. 194)

Há aqui diversas alusões a tentativas falhadas de seu cantar, as quais evocam recorrências internas, como "hastes" e "ramos", que em outros momentos aparecem associadas à vontade ascensional de sua poesia, como já referido, ou ao alcance máximo da palavra poética, como em "Metamorfoses da palavra", de Até amanhã: "A palavra

\footnotetext{
${ }^{269}$ Eugénio de Andrade costumava dizer que Camilo Pessanha era o único poeta que ele tinha como "mestre", conforme afirmou na entrevista "Confissões de um poeta". Macau. N. 29. Macau: Imprensa Oficial, novembro de 1990, p. 25. Pela "ligação umbilical" que sua poesia mantinha com a de Pessanha, Eugénio dizia se sentir "herdeiro espiritual" do poeta. A imagem branca do lenço de linho entre "espinheiros" nos faz lembrar, ainda que vagamente, de versos melancólicos de Pessanha, como o de "Caminho II": "É longe, é muito longe, há muito espinhos!", em que ele alude também a um lugar distante e inalcançável. Ou de maneira ainda mais indireta, os versos de outro soneto, em que o eu lírico procura estender a mão à imagem branca de uma mulher entre a folhagem: "Oh vem, de branco, do imo da folhagem! / Os ramos, leve, a tua mão aparte. / Oh vem! Meus olhos querem desposar-te, / Refletir virgem a serena imagem". Cf Clepsydra. Camilo Pessanha. Edição crítica de Paulo Franchetti. Lisboa: Relógio D’Água Editores, 1995.
} 
nasceu: / nos lábios cintila / [...] de ramo em ramo voa, / na luz se derrama. / A morte não existe: / tudo é canto ou chama" (1966, p. 134). Ou em "Nocturno de Fão", de Ostinato rigore: "De palavra em palavra / a noite sobe / aos ramos mais altos / e canta / o êxtase do dia" (1966, p. 224).

O último verso encerra o poema da mesma maneira em que fora aberto: "Que rompam as águas!", em sugestão do "desaguar", que se pretende em Mar de setembro, do rio ao mar aberto: a chegada implica o percorrer total do ciclo, em que fim e começo coincidem, ininterruptos como o "mar", em perpétuo recomeço. Além do mais, em alusão à figura bíblica de Moisés, que "rompeu as águas" para poder passar com segurança, no Antigo Testamento - como se pudesse paralisar o tempo e os espaços mundanos a fim de estabelecer um tempo outro, mítico -, o sujeito eugeniano clama também aqui por uma descontinuidade, a ser realizada, como pretende, no corpo e na palavra. O verso poderia soar ainda como um bordão poético, que liga a poesia à práxis; um imperativo para que o tempo cesse, ou verta-se, descontínuo. No entanto, esse mesmo verso, no modo subjuntivo - que geralmente caracteriza uma espécie de pretensão - não escamoteia as hesitações e os "tropeços" do cantar eugeniano, exprimidos também por meio das constantes perguntas ao longo das sétima e nona estrofes.

De fato, dez poemas do livro contêm interrogações, número bastante alto, se comparado aos demais livros da coletânea. Lidas como uma espécie de interrupção na dinâmica fluida da poesia eugeniana, as interrogações propõem novos caminhos; apresentam, assim como a figura do "mar", uma suspensão do sentido: pausas que ecoam aquele silêncio tão aspirado quanto temido pelo sujeito eugeniano.

\section{Glosa}

Que voz se desprende, hesita, tropeça?

Que pedras tacteia, que ramos alcança?

Que fonte pressente? que rio procura?

Que ritmo persegue, que palavras ama? 
Que sombras repele, que luzes derrama?

(ANDRADE, 1966, p. 178)

O ritmo fluido como que a "desaguar" na imagem final do "mar", de "Quase nada", poema imediatamente anterior a este, em que o sujeito de passagem levava uma "criança que nunca viu o mar" (1966, p. 177), aparece aqui suspenso, porque questionado - hesitação que se prolonga através dos dois "poemas-perguntas" seguintes: "Não perguntes, escuta...", quinto do livro, e "Que voz lunar...", sexto do livro.

No poema em questão, sob o título sugestivo de "Glosa" - texto que contém um comentário ou interpretação de outro texto, ou que se apresenta como mote de outro poema - encontramos, novamente, a intersecção com outros poemas eugenianos, na recuperação dos signos constantes ("fonte", "rio", "luz", "pedra") e de trechos de outros poemas ("tropeça", "hesita", "ramos alcança”, "sombras repele", "palavras ama”, etc.). Gesto que explicita, mais uma vez, a intenção de revisitar esta poesia, com o objetivo de indagar por novos caminhos.

Assim, o poema seguinte, "Não perguntes, escuta...", parece propor uma "resposta" às indagações do poeta, mesmo que por meio de novas perguntas:

Não perguntes, escuta...

Donde vem? De que fonte ou boca ou pedra aberta? É para ti que canta ou, simplesmente, para ninguém?

Que juventude te morde ainda os lábios? Que rumor de abelhas te sobe pela garganta?

Não perguntes, escuta:

é para ti que canta.

(ANDRADE, 1966, p. 179) 
Neste "tu" ao qual o poema se oferece pulsa uma série de referências diferentes, motivadas tanto pelo anseio dialogante da poesia eugeniana como por uma espécie de encontro consigo mesmo, em que a poética eugeniana se autodirige e se autoformula em imagens umbilicais, como lemos as cavidades da "fonte", "boca", "pedra aberta", "lábios", "garganta"; e por meio também das indagações propostas. O poema reafirma certa "confiança" que havia sido posta em causa pelas indagações anteriores: "Não perguntes, escuta". O título do poema contém esse mesmo verso central seguido de reticências: "Não perguntes, escuta...", fazendo ecoar uma espécie de silêncio, também exaltado pelo pedido para que se calem as perguntas no próprio ato de escutar.

No entanto, no poema-pergunta seguinte, o "silêncio" aparece com a necessidade de ser "quebrado":

\section{Que voz lunar...}

Que voz lunar insinua

o que não pode ter voz?

Que rosto entorna na noite todo o azul da manhã?

Que beijo de oiro procura uns lábios de brisa e água?

Que branca mão devagar quebra os ramos do silêncio?

(ANDRADE, 1966, p. 180)

O silêncio é tensionado na poesia eugeniana, como demonstram os poemas acima, dispostos lado a lado em Mar de setembro: de um lado, como a própria face oculta da palavra poética, "Que voz lunar insinua / o que não pode ter voz?”; e, de outro, como o "nada" contra o qual a poesia se ergue, "noite" em que se "entorna" todo o "azul" da "luz" e da "manhã".

A dinâmica dos poemas-perguntas neste livro se aproxima da movimentação imposta pelo signo central: assim como as "interrogações", o "mar" pode ser perscrutado tanto em sua "música" mais "luminosa" (ou "silêncio" fecundo) quanto em seu "silêncio" mais árido e mais sombrio. O gesto de indagar é, portanto, semelhante ao 
“desaguar" no "mar". Sintetiza o termo de chegada e a busca de novos caminhos: "ir e vir" constante; "alcançar" e "derramar" (1966, p. 178), por um lado; transgredir ou ultrapassar, por outro (“procurar", "perseguir", “tactear”, “desprender" - 1966, p. 178).

Por meio de um paradoxal esvaziamento de sentido, tanto as perguntas, a pôr em causa o que fora anteriormente construído, quanto a imagem imprecisa do "mar", dão à poesia eugeniana maior disponibilidade de sentido. Dos signos analisados, talvez seja o "mar" aquele que possua o mais alto grau de ambiguidade, por se aproximar, de maneira ainda mais intensa, de uma concepção musical do significado - tal como entrevista, por exemplo, no poema de abertura, já analisado acima, em que esse signo determinava o ritmo oscilante do poema, antes a sugerir do que significar diretamente; antes a "repousar" na imagem do que correr com o discurso concatenante. O ritmo, o contorno, o horizonte imagético, enfim, a forma do "mar", antecedem qualquer transmissão direta de uma ideia, ondulando, como no poema de abertura, por exemplo, oposições que se anulam ou se apaziguam no leito da imagem em expansão e na cadência geral do poema.

Desse modo, o "mar" apresenta significados tão diversos que qualquer tentativa de interpretação fixaria aquilo que essencialmente se demonstra vago e instável.

Ao acompanhar o movimento rotatório dos signos em Poemas, procuramos traçar certas relações de sentido, sempre ondulatórias e de algum modo, precárias, já que ditadas por imagens que regressam explícita ou implicitamente, refletindo todas as demais, adiando o sentido para uma leitura que se quer cada vez mais ampla - a realizar-se, talvez, no mito cíclico da própria obra, sempre incompleto e infinito. Assim, conforme viemos observando, cada imagem recorrente se torna um "signo" versátil, que encarna como função o próprio ato da escrita errante, a formular uma arte poética que aspira, antes de tudo, captar a essência da própria vida e da natureza humana: sempre contínua e transitória.

$\mathrm{Na}$ descrença em uma realidade transcendente e eterna, a poesia eugeniana intenta vivenciar, na própria transitoriedade da vida, alguma durabilidade. A intersecção das imagens proporciona o conseguimento de outro tempo, ainda que precário, dentro da "poética do instante", como se define a poética eugeniana. Assim, no "mar", espaço e tempo se anulam; o homem pode ali tornar "criança" outra vez (como aquela que “nunca viu o mar"), e recomeçar nova visão de mundo, embalada na potência multiplicativa da palavra poética. Nessa mesma linha, situamos o sentido (de certa 
maneira aberto e flexível) do "silêncio" na poesia eugeniana, o qual frequentemente se associa à figura central e descontínua do "mar", às interrupções propostas pelos versosindagações, e também aos "ramos altos", como temos analisado, geralmente rodeados de "luz".

No décimo poema do livro, "Matinalmente", os tão recorrentes "ramos altos" os quais associamos também à questão do "silêncio", pela "distância" que apresentam: ponto de expansão e dissolução - aparecem no mesmo lugar privilegiado do "mar": ponto de alcance máximo da palavra poética; alargamento, espaço de repouso e durabilidade, perseguido pela "luz":

\title{
Matinalmente
}

Que ronda matinal, que luz tão jovem treme, e se demora, nos ramos altos, e já distante nem lembra que pousou?

(ANDRADE, 1966, p. 185)

No entanto, já percebemos, nesse poema, um gradual afastamento desse instante luminoso, síntese de visão e conhecimento. A permanência já esmorece, assim como a "luz" que treme; e há certa tristeza pressentida, ainda que amena, na indagação final que o poema propõe, a lamentar tal transição, em que homem e memória se esvaem diante de um silêncio maior, progressivo, a dissociar tudo o que fora antes construído.

No décimo nono e antepenúltimo poema do livro, a melancolia é agora expressa mais diretamente pelo sujeito, que assiste ao que parece ser um fim de tarde:

\author{
Arima \\ Uma gaivota... - dizes. \\ Sim, uma gaivota \\ passa distante, e arde. \\ O teu rosto é azul, \\ e contudo está cheio \\ do oiro da tarde. \\ Uma gaivota. \\ Alma do mar e tua, \\ abandona-se à luz. \\ E na boca nem eu sei
}


se me nasce o coração,

ou é a lua.

(ANDRADE, 1966, p. 199)

Ligada ao "mar", temos aqui, novamente, o voo da gaivota, nomeada em sua natureza de palavra: "Uma gaivota... - dizes". Como a "luz" a sumir no poema mais acima, a "ave" aqui já "passa distante", "abandona-se à luz". O espaço poético interligado por "mar", "ave" e "luz" escurece. Os referentes surgem como transitórios. Perdem-se no tempo e no oblívio. No centro, há um ponto de equilíbrio, mesmo que momentâneo, entre a fluidez da paisagem. A "boca", que parece ser a do amado, ainda que situada entre o "coração" do homem eugeniano e a "lua" no céu, participando da composição simétrica da paisagem marítima - como já acontecia no poema "Espelho", analisado acima, em que a "boca" também configurava o centro de uma paisagem definida por oposições, "a boca / onde nasce o sol /onde nasce a lua" (ANDRADE, 1966, p. 191) -, não aparece, como nos livros anteriores, equiparada à "fonte”. Ou seja, não guarda relação com a origem, mas com uma paisagem que aponta para a iminência do fim, metaforizada pela lenta passagem do dia para a noite. Durante o entardecer, a voz também se torna mais "lunar" e suavemente melancólica. O rosto do amado, já "azul" com o crepúsculo, ainda reflete o "oiro da tarde", assim como a "lua" ainda reflete a luz do sol. Há uma transferência de "luzes", que mínguam do sol para a lua, mas no centro do poema, as reminiscências ainda resistem e se prolongam. O momento é esplendoroso, ainda que transitório.

Se voltarmos ao poema "Que voz lunar", analisado acima, encontramos a mesma composição simétrica entre "sol" e "lua", extremidades que se refletem no poema. O rosto do amado também aparece como elo, agora, porém, entre planos invertidos: "Que rosto entorna na noite / todo o azul da manhã?" A “voz lunar” é nomeada, insinuando o silêncio ("a voz lunar insinua / o que não pode ter voz"). Por seu turno, a "branca mão devagar" quebra os "ramos do silêncio" (ANDRADE, 1966, p.180). Há uma espécie de compensação e equilíbrio de forças. A palavra parece sobrevir das reminiscências entre os planos que se alternam.

Desse modo, a imagem marítima ora é reencontrada no silêncio, celebrada como "música", conforme no poema de abertura, ora se dissipa no silêncio, como a "boca" do poema acima, a refletir a luz minguada da "lua" - que, por associação, nos traz aquela mudez referida nos versos "a voz lunar insinua /o que não pode ter voz", do poema 
"Que voz lunar". O silêncio aqui se reverte, cessa de significar, dissipa-se. O sujeito se vê novamente diante de uma noite maior, representada pela presença da "lua", como se a "luz" fulminante de outrora se transformasse agora em uma luz melancólica e noturna. A noite por vir é destituída de sentido. O sujeito eugeniano mais uma vez mergulha em angústia, e o último poema do livro, "Que diremos ainda", desponta como ápice desse tom que vinha gradualmente tristonho:

\section{Que diremos ainda?}

Vê como de súbito o céu se fecha sobre dunas e barcos, e cada um de nós se volta e fixa os olhos um no outro, e como deles devagar escorre a última luz sobre as areias.

Que diremos ainda? Serão palavras isto que aflora aos lábios?

Palavras?, este rumor tão leve que ouvimos o dia desprender-se?

Palavras, ou luz ainda?

Palavras, não. Quem as sabia?

Foi apenas lembrança de outra luz. Nem luz seria, e só um outro olhar.

(ANDRADE, 1966, p. 201)

Cai a noite, e a "última luz" escorre sobre as areias. O sujeito se vê impotente diante do poder dissolvente da melancolia. Toda a "luz" de outrora é agora encarada como esforço inútil, reflexo de um afeto frágil e passageiro: "só um outro olhar". A passagem do dia à noite (e, talvez, a alusão ao fim do verão, como no título do livro) encarna a dor e a noção de perda. As palavras revelam-se desgastadas e impotentes contra a escuridão que vai cegando o sujeito - um "olhar" torna-se "só mais um", perdendo a relação com o ato de conhecer, de ver e depreender sentido.

Desse modo, o sujeito vai, gradualmente, deixando de ver, de ouvir ("rumor tão leve"), de saber ("Quem as sabia"), de lembrar, de amar, de sentir, de dizer. O poema ameaça morrer no silêncio. A impermanência das imagens relaciona-se, pois, à impermanência das interações entre sujeito e mundo. A paisagem marítima ${ }^{270}$, no

${ }^{270} \mathrm{O}$ "mar", neste poema, é um signo oculto. Porém, ele participa da paisagem, composta por outros elementos marítimos, como barco, dunas, areia. 
poema acima, referida pela presença de "dunas", "barcos", "areias" e "luz", surge agora em sua dimensão de morte e perda, ritmo natural contra o qual nada valem os esforços do sujeito e o poder encantatório do amor e da palavra poética.

Neste ponto, chamamos a atenção para um diálogo de certa maneira incontornável na análise da poesia eugeniana. Desde As mãos e os frutos, a "água" aparece como elemento fundamental na poesia de Eugénio de Andrade, e em Coração do dia, como também em Mar de setembro, passa a nutrir e a estruturar a arte poética eugeniana. A essa dimensão líquida, acrescente-se a referência aos "olhos" fugidios deste último poema de Mar de setembro, dos quais "devagar escorre a última luz sobre as areias", e temos o que poderia ser uma conversa com certos poemas de Clepsydra, de Camilo Pessanha, poeta a quem o próprio Eugénio de Andrade chamava de "mestre", grande influência para sua poesia:

[24]

(A João Jardim)

Imagens que passaes pela retina Dos meus olhos, porque não vos fixaes? Que passaes como a agua cristallina Por uma fonte para nunca mais!...

Ou para o lago escuro onde termina Vosso curso, silente de juncaes, E o vago medo angustioso domina, - Porque ides sem mim, não me levaes?

Sem vós o que são os meus olhos abertos? - O espelho inutil, meus olhos pagãos! Aridez de successivos desertos...

Fica sequer, sombra das minhas mãos, Flexão casual de meus dedos incertos, - Estranha sombra em movimentos vãos.

(PESSANHA, 1995, p. 102) $)^{271}$

Guardadas as diferenças, já que o "lago escuro" nesse soneto de Pessanha revela um mais fúnebre e estagnado termo de chegada do que a imagem do "mar" em Eugénio 
de Andrade, observamos em ambos relações de ordem semelhante quanto ao motivo da “água", ligado à percepção do fluir irreparável do tempo e à visão da realidade em perpétuo movimento. ${ }^{272}$

Conforme explica Paulo Franchetti ${ }^{273}$, na experiência dolorosa descrita por meio de imagens em movimento incessante, que evocam "fuga, mobilidade; [...] desligamento, ruptura, desenraizamento" (2001, p. 34) na poesia de Camilo Pessanha, podemos ler também o desejo do sujeito de estar morto, de se subtrair à terra ou às águas; e o "desejo de acompanhar as imagens até o momento em que elas finalmente se detêm, no lago escuro e silencioso e de, quem sabe, lá as recuperar" (2001, p.61).

$\mathrm{Na}$ reação dolorosa ante a transitoriedade, o sujeito expressaria o desejo de interromper e se apropriar do movimento, transgredindo aquilo que caracteriza sua própria condição de sujeito. O poema tornar-se-ia, assim, o lugar raro em que algo se preserva para ser contemplado (FRANCHETTI, 2001, p. 70), local de repouso e integração momentânea do sujeito com o mundo.

Porém, diante da imagem encontrada, espécie de "rastro" ainda não apagado, o sujeito se expressa de maneira conflituosa: de um lado, há a total entrega à "presentificação" das imagens, espécie de "atualização mítica", conforme denomina o crítico, e de outro, a revelação de um sentimento de inutilidade de tal esforço, que permeia a "disposição melancólica" dessa poesia. Para Franchetti, toda disposição melancólica é essencialmente reflexiva, "pois se define simultaneamente como consciência da transitoriedade do mundo e percepção da transitoriedade dessa mesma disposição, que é um momento privilegiado em que se opera uma efêmera suspensão da agonia" (FRANCHETTI, 2001, p. 87).

Desse modo, o caráter metalinguístico e analítico da poesia de Pessanha derivaria do sentimento de melancolia que aponta para a "capacidade ou incapacidade de a linguagem poética apreender a relação do sujeito com a realidade" (FRANCHETTI, 2001, p. 89).

272 Cf. Bárbara Staggiari (O simbolismo na obra de Camilo Pessanha. Lisboa: 1982, p. 108): "Essa dimensão líquida do universo de Pessanha ligou-se, por um lado, à percepção do fluir imparável do tempo; e, por outro, conjuga-se com uma visão da realidade que não é menos flutuante, fugidia e indefinível, porque em perpétuo movimento". Ver também Esther de Lemos (A Clepsidra de Camilo Pessanha. Viseu: Editorial Verbo, 1981, p. 14): "O seu sentido de tempo e de movimento - principais determinantes de um estado de espírito que conduz à criação poética".

${ }^{273}$ Nostalgia, exílio, melancolia: leituras de Camilo Pessanha. São Paulo: Edusp, 2001. 
$\mathrm{Na}$ poesia eugeniana, encontramos tensão semelhante, em que se alternam momentos de descoberta e êxtase mítico, momentos trágicos e intensos, e momentos melancólicos e reflexivos, em que sua arte poética explicita a revisão de seus passos e caminhos. Tanto em Eugénio de Andrade quanto em Pessanha, há a tentativa de formulação de uma arte poética na intersecção entre o que poderíamos denominar uma "poética do instante" e uma "poética da melancolia".

Em ambas as obras encontramos o tema da "incomensurabilidade entre o desejo, ou sonho e a realidade", como aponta também Óscar Lopes, grande leitor e crítico dessas duas poesias: “A realidade é mais imaginativa do que nós, ou antes, nós só não perderemos a realidade se corrermos sempre atrás dela a refazer imagens" ${ }^{274}$. Desse modo, essa poesia, manifestada como procura e objeto do desejo, está sempre a refazerse, no "superar contínuo do englobante"; no "salto em direção a novas estruturas de compreensão e valor” (LOPES, 1969, p. 202). Assim, cada palavra aparece como síntese "entre qualquer ser inconsciente e a consciência disso"; manifestação de esperança inerente à angústia, ao desespero perante a passagem do tempo e a mortalidade (LOPES, 1969, p. 203).

Nesse caminho do meio, tentativa de síntese, Eugénio de Andrade também optou por insinuar antes, em vez de dizer diretamente, assim como fizera Camilo Pessanha. Como potências sugestivas, Eugénio de Andrade explorou a fluidez da linguagem e os efeitos de música, que já na poesia de Pessanha tanto nos provocavam:

[...] Maravilhas de vivência recorrente, absolutamente inexplicáveis, que as retóricas banalizam sob a designação de metáfora: a transparência da água identifica-se à do tempo, quinta-essência incolor deste facto que é o de o conjunto das coisas concretas se transformar num emaranhado de reversibilidades e irreversibilidades. Mas essa metáfora água-tempo (ou água-memória, também) torna-se ainda mais perturbante se repararmos que o espaço e o tempo nos aparecem, assim, inextricáveis, e que a abstração destas categorias se confunde afinal, na poesia, com a vibração de imagens concretas, sensoriais.

(LOPES, 1969, p. 206)

O poema eugeniano ergue-se como um composto de visões, afetos, reminiscências, estímulos sensoriais, etc., sempre a interseccionar a parte com o todo

274 "O quebrar dos espelhos". Ler e depois - crítica e interpretação literária. Vol.1. Porto: Editorial Inova, 1969, p. 200. 
englobante da obra, no esforço de encontrar, na analogia, nas interpelações constantes e na repetição, a fusão realizada na imagem - ainda que sempre provisória.

\subsection{0 "Verão" da "luz" e dos "frutos" maduros}

Sabor de ser ardor de florir, rumor de amanhecer. (Eugénio de Andrade, 1966, p. 214)

O ritmo já depurado em Mar de setembro aperfeiçoa-se em Ostinato rigore (1963-1965), sétimo e último livro da coletânea, cujo recorte epigramático permite pausas mais intensas entre os versos, sugerindo, musicalmente, a presença do silêncio "sabor eterno", como diziam os versos de "À tua sombra", do livro anterior: "Apetece morrer / morrer ou cantar" (ANDRADE, 1966, p. 183). O sétimo livro perpetua, desse modo, aquele gesto da poesia eugeniana que vimos ser traçado desde o primeiro livro da coletânea, e que repetidamente vinha dar no encontro imagético com o "mar" do livro anterior, a expressar, mais intensamente, a vontade de entrega e aceitação da morte - em que cantar é também "morrer" e deixar calar. A morte tem a naturalidade do ritmo eterno do "iam, vinham, iam" marítimo, e o canto alarga o campo do indizível: "Morre / de ter ousado / na água amar o fogo”, nos versos já de Ostinato rigore (1966, p. 210). Morte que, através de Maurice Blanchot, associamos a um modo de "esquecimento": "[...] para que nesse esquecimento, no silêncio de uma profunda metamorfose, nasça finalmente uma palavra, a primeira palavra de um verso" (BLANCHOT, 1987, p. 83).

Blanchot discute o espaço da morte na obra de arte, em $O$ espaço literário, e chama a atenção para a grande transformação que todo artista sofre no trabalho da obra: “Todo trabalho nos transforma, toda ação realizada por nós é ação sobre nós" (1987, p. 86) - de modo que a obra surge num processo de profundo "aniquilamento de si mesmo" 275 . No entanto, toda obra se faz também, conforme o crítico, na própria conquista da morte:

\footnotetext{
${ }^{275}$ Blanchot define a tarefa poética como "risco" e "morte": "Risco que atinge o uso normal do mundo, o uso habitual da palavra, que destrói todas as garantias ideais, que retira ao poeta a segurança física de viver, expõe-no, enfim, à morte, morte da verdade, morte da sua pessoa, entrega-o à impessoalidade da morte" (BLANCHOT, 1987, p. 106).
} 
Não se pode escrever se não se permanece senhor de si perante a morte, se não se estabeleceram com ela relações de soberania. [...] A arte é relação com a morte. Por que a morte? Porque ela é o extremo. Quem dispõe dela, dispõe extremamente de si, está ligado a tudo o que pode, é integralmente poder. A arte é senhora do momento supremo, é senhora suprema.

(BLANCHOT, 1987, p. 86)

Essa fusão contraditória entre entrega e superação da morte - entre calar e dizer, afirmar e negar, lembrar e esquecer - é prolongada em Ostinato rigore. Por meio da lapidação rigorosa da palavra e do ritmo, Eugénio de Andrade obtém, nesse livro, o difícil equilíbrio entre a contenção da expressão e a expansão explosiva da energia poética; máxima fusão e entrega:

\section{Soneto menor à chegada do verão}

Eis como o verão chega de súbito, com seus potros fulvos, seus dentes miúdos, seus múltiplos, longos, corredores de cal, as paredes nuas, a luz de metal, seu dardo mais puro cravado na terra, cobras que despertam no silêncio duro ...

Eis como o verão entra no poema.

(ANDRADE, 1966, p. 205)

Embora em Ostinato rigore seja mais difícil apontar apenas um único signo recorrente, pois, conforme veremos, o léxico circunscrito de Eugénio de Andrade aqui aparece de maneira mais entrosada, participando da dinâmica equilibrada do livro e evidenciando mais enfaticamente as contiguidades entre os elementos, reclamamos para o "verão" (presente em oito poemas, tanto no primeiro quanto no último do livro) ${ }^{276}$,

\footnotetext{
${ }^{276} \mathrm{O}$ "verão" é também vertente de "luz", presente em pelo menos cinquenta por cento dos poemas, que, por sua vez, pode aparecer também na forma do "dia" (em oito poemas) e da "manhã" (em sete poemas).
} 
sumária importância, por metaforizar, como nesse poema de abertura, certo "termo de chegada" - solstício da palavra poética, movimento que já se aproxima do repouso, fusão.

O signo do "verão" se desdobra, como veremos, em outros tantos signos, como os "frutos", a "terra" e a "luz", por exemplo, de maneira bastante semelhante ao que acontecia no primeiro livro da coletânea, As mãos e os frutos, que entrosava uma série de "ciclos" poéticos, a modularem-se não só entre os signos das "mãos" e dos "frutos", como apontamos, mas também ao redor do "rio", da "fonte" e do "pássaro", por exemplo $^{277}$ - ao passo que nos demais livros, os múltiplos signos geralmente reaparecem sob a égide de um signo mais dominante, ou sob uma espécie de unidade de tom, sem constituírem vários "sistemas" interrelacionados, ou pelo menos não tão constantes como no primeiro livro. Ostinato rigore, de modo semelhante, parece retomar mais diretamente os signos recorrentes do primeiro livro, apresentando-os, no entanto, sob a "luz" mais madura do "verão".

No poema de abertura acima, após uma série de imagens que se alongam por entre o que poderia ser um caminho percorrido, como "longos corredores", "paredes nuas", "luz de metal"; pelo correr dos "potros fulvos" e do "dardo" que crava a "terra", despertando "cobras" - surge o "verão". Em sua instância metapoética, ele interrompe o fluxo do poema e oferece uma espécie de repouso, reforçado pela mudança repentina do ritmo e pela concisão do último dístico - chave do "soneto menor", como anunciado no título.

As repetições sonoras de /u/ e /i/ em "súbito", "potros fulvos", "dentes miúdos", "múltiplos corredores de cal", "paredes nuas", "luz de metal" e "dardo puro", ao se alinharem até "silêncio duro", sugerem relações entre a sonoridade melancólica das vogais fechadas e a ideia de silêncio, interrompido pelo mover das cobras à chegada do "verão", máxima luminosidade a penetrar o poema.

\footnotetext{
${ }^{277} \mathrm{Em}$ As mãos e os frutos, os seguintes poemas convocam o signo do "rio" : 2, 8, 10, 16, 18, 20, 28, 30; da "Ave": poemas 3,5, 16, 24, 31; da "fonte": poemas 3, 9, 10, 25, 28, 29; da "noite": poemas 7, 12, 25, 26, 29 ("madrugada"), 32, 36; das "mãos": poemas 1, 7, 11, 16, 17, 19, 20, 33, 36; dos "frutos": poemas 1, 13, 14 ("pomar"), 15, 22 ("pomar"), 23, 30, 33, 34, 35; do "corpo" : poema 27; do "corpo" associado à terra: poemas $6,8,19$; do "corpo" associado ao rio ou à água: poemas 10, 13, 18, 28; da "terra": poemas $11,19,21$ e 30. A interação entre os ciclos evidencia a contiguidade entre todos os elementos, como em uma "partitura" musical modulando-se entre notas, conforme apontou Óscar Lopes (Cf. análise do primeiro livro). Em Ostinato rigore, os signos se desdobram em estruturas cíclicas semelhantes. O diálogo com o primeiro livro nos parece bastante evidente, em afirmação de uma concepção de poesia cíclica ou espiral, construída ao longo de toda a coletânea.
} 
A descrição da luz no "verão", intensa como a hora do meio-dia ${ }^{278}$, a chocar-se contra a "cal" dos "corredores" e das "paredes nuas", possui também um caráter cegante e estéril: no zênite, a luz não permite sombras nem contrastes. A brancura total atordoa e aniquila, podendo ter o mesmo efeito que a escuridão: reivindica também o caos; dissolve qualquer imagem humana do mundo; dificulta o trabalho da percepção e da apreensão do sentido.

Desse modo, no poema acima, o "verão" é dúbio: por um lado, desperta as "cobras" do silêncio duro e estéril - relacionadas, talvez, a uma espécie de hibernação invernal. Por outro, como auge da luz, prenuncia já uma dada decadência da luz.

No entanto, ao suceder uma longa série de imagens que suscitam esforço e sofrimento, o "verão", ao "penetrar" o poema na estrofe final, nos transmite a ideia de superação; de algo arduamente conseguido. O tema de uma dada superação pela poesia, seja da morte, do silêncio, seja do sentimento de melancolia, vencidos quando incorporados como material do poético, é recorrente ao longo do livro, como atesta também o vigésimo terceiro poema:

\section{Despedida}

Colhe

todo o oiro do dia

na haste mais alta

da melancolia.

(ANDRADE, 1966, p. 238)

Nesse poema, o auge do que poderia ser a palavra poética, obtida através de cuidado, esforço e trabalho, como sugere o verbo "colher", associa-se à ideia de cume e de luminosidade, assim como no já citado anteriormente "Nocturno de Fão", décimo quarto do livro:

\section{Nocturno de Fão}

De palavra em palavra

a noite sobe

aos ramos mais altos

e canta

\footnotetext{
${ }^{278}$ Não é incomum a hora do "meio-dia" encontrar-se associada à ideia de anúncio da morte, de ocaso, já que $o$ auge da luz vem sucedido pela decadência da luz.
} 
o êxtase do dia.

(ANDRADE, 1966, p. 224)

Embora o "verão" aqui não apareça, o verso "êxtase do dia" evoca as mesmas ideias que a ele associamos: superação pelo esforço, encontro, repouso e fusão. O êxtase e a plenitude poética aparecem ligados à "luz" do "dia", como também neste verso do terceiro poema: "Ao encontro do rosto/ da manhã caminhas.// A terra madura/ está na tua frente" (1966, p. 208); fixando-se também na imagem recorrente da "terra", como vimos no poema de abertura; algumas vezes "inocente", como no quinto poema do livro: "A terra inocente/ abre-se ao ardor/de oiro de uma flauta" (1966, p. 212) imagem que nos faz lembrar, por associação imediata, as "cobras" a despertar do "silêncio duro" do poema de abertura, já que ambas as imagens sugerem uma espécie de "encantamento", como se a poesia se fizesse no domínio de forças, na superação da morte e do silêncio, assim como a "flauta" que encanta as "cobras" e a "terra". Tanto a "flauta de oiro" quanto as "cobras", portanto, que no verão despertam do "silêncio", unem as ideias de "luz" e "som" na referência ao canto poético.

Desse modo, tanto quanto ao cume das "hastes" como ao seio da "terra", abre-se o poema também ao "verão": "verão" dos frutos maduros, que agora surgem nomeados, como no décimo poema do livro: "framboesas", "maçã", "laranja", "uva" e "romãs"; numerados em dísticos como glóbulos autônomos: recurso visual que imita a entrega dos frutos maduros ao alcance da mão.

\section{Natureza morta com frutos}

1.

O sangue matinal das framboesas escolhe a brancura do linho para amar.

2.

A manhã cheia de brilhos e doçura debruça o rosto puro na maçã.

3.

$\mathrm{Na}$ laranja o sol e a lua dormem de mãos dadas.

4.

Cada bago de uva sabe de cor o nome dos dias todos do verão. 
5 .

Nas romãs eu amo

o repouso no coração do lume.

(ANDRADE, 1966, p. 220)

O poema organiza-se por meio da soma de aforismas ou fragmentos, os quais remetem a uma totalidade suspensa. Em todo o livro, há sete composições como essa, em dísticos numerados, o que constitui uma novidade formal em Poemas. Como se sabe, certos traços da lírica moderna, admitidos principalmente desde A estrutura da lírica moderna, de Hugo Friedrich ${ }^{279}$, tais como despersonalização, concentração da expressão, dicção coloquial, consciência da forma, liberação da palavra poética - tanto em termos rítmicos ${ }^{280}$ quanto imagéticos, em que se procurou, por meio de diversas técnicas novas, a fusão de sensações e temporalidades diferentes, numa tentativa cada vez maior de aproximação da vivência e da consciência modernas -, etc., tiveram início nos experimentos dos poetas simbolistas franceses, nomeadamente Rimbaud, Baudelaire e Mallarmé. ${ }^{281}$ De modo geral, todas essas características apontadas são visíveis, como temos visto, na poesia eugeniana, não só na relação do poeta com a música de seus versos, mas também no tratamento imagético. Porém, de maneira mais específica, é possível ainda identificar, em poemas como este "Natureza morta com frutos", acima, de Ostinato rigore, proximidades com a experiência poética dos imagistas, corrente literária também moderna e influenciada pelos simbolistas franceses, mas com certas características próprias.

De acordo com William Pratt, o imagismo não constituiu um movimento ${ }^{282}$, mas uma sucessão de breves, esporádicos e descontínuos "momentos criativos" entre 1910 e

\footnotetext{
${ }^{279}$ FRIEDRICH, HUGO. A estrutura da lírica moderna. São Paulo: Duas Cidades, 1978.

${ }^{280} \mathrm{O}$ verso livre passou a obedecer antes à música natural da fala e à organicidade da obra do que a modelos de rima e métrica preestabelecidos. Ezra Pound foi um dos primeiros poetas modernos a articular teoricamente uma defesa da inovação rítmica no verso, definindo-a como procura pelo "ritmo absoluto": "I believe in an 'absolute rhythm', a rhythm, that is, in poetry which corresponds exactly to the emotion or shade of emotion to be expressed [...]. Every true poem should have its own inner order". ("Eu acredito em um 'ritmo absoluto', um ritmo que na poesia corresponde exatamente à emoção ou ao tom que se pretende expressar [...]. Todo verdadeiro poema deveria ter sua própria ordem interna". Tradução nossa). citado em The imagist poem. William Pratt. Oregon: Story Line Press, 2001, p. 33.

281 "Os fundadores e, ainda hoje, mestres da lírica moderna da Europa são dois franceses do século XIX, Rimbaud e Mallarmé. Entre eles e a poesia de nossa época, perduram elementos em comum que não se pode explicar como simples influxos nem se precisa explicar como tal, mesmo nos lugares em que os influxos sejam reconhecíveis. Trata-se de elementos estruturais em comum ou, melhor, de uma tessitura básica, surpreendentemente constante nos mais variados fenômenos da lírica moderna. [...] As leis estilísticas dos poetas atuais tornam-se claras a partir de Rimbaud e Mallarmé" (FRIEDRICH, 1978 p. 9). 282 "The Imagist poem was a hybrid, and being a hybrid it throve by a process of continual cross-
} 
1920, em que um grupo de poetas ingleses e norte-americanos, como T.S. Hulmes, F.S. Flint e Ezra Pound, e mais tarde, H.D., Richard Aldington e Amy Lowell trabalharam juntos em busca de novas formas e modelos poéticos. Insatisfeitos com a rigidez da poesia inglesa de seu tempo, esses poetas voltaram-se a modelos do passado, provenientes principalmente da lírica grega, medieval, da poesia oriental e da poética simbolista francesa, ${ }^{283} \mathrm{em}$ busca de realizar aquilo que seria uma mudança estrutural na cadência do verso inglês e no sentido e apresentação da metáfora.

Essa nova relação com a palavra e com a experiência poética passou a ditar a sensibilidade dos poetas posteriores, influenciando de maneira determinante a produção da poesia de língua inglesa do século XX e suas obras mais importantes, como a de T.S. Eliot, D.H. Lawrence, William Carlos Williams, Marianne Moore, Wallace Stevens ${ }^{284}$, E.E. Cummings, etc:

Não há dúvida de que o Imagismo foi a via pela qual muitos dos mestres do verso moderno inglês descobriram seu próprio estilo, e de alguma maneira, todo poeta importante do século vinte era um imagista, assim como todo poeta importante do século dezessete era um sonetista. ${ }^{285}$

(PRATT, 2001, p. 21) ${ }^{286}$

Para além do rigor, concentração da expressão e princípio da economia defendidos pelos imagistas, identificamos também, em Ostinato rigore, maior precisão e transparência no uso da imagem e a predominância daquilo que Ezra Pound

fertilization". ("O poema imagista era um híbrido, e sendo um híbrido, ele constituía-se de um contínuo processo de cruzamentos". Tradução nossa). The imagist poem. William Pratt. Oregon: Story Line Press, 2001, p. 19.

${ }^{283}$ Segundo Pratt, uma forma propriamente imagista nunca foi fixada: "The whole force of Imagism was in the direction of variety, irregularity, and individuality, for it had begun as a protest against the rigidity of traditional English verse forms, and it continually sought new models to imitate and transform, never setting permanently on any of them" (PRATT, 2011, p. 31). ("Toda a força do imagismo direcionou-se para a variedade, irregularidade e individualidade, pois o imagismo começou como um protesto contra a rigidez do verso inglês tradicional, e continuamente procurou por novos modelos para imitar e transformar, sem se estabelecer permanentemente em nenhum deles." Tradução nossa).

${ }^{284}$ Wallace Stevens, poeta americano contemporâneo de Eugénio de Andrade, embora tenha realizado críticas pertinentes em relação à teoria dos imagistas, afirmou também: "Imagism is an acient phase of poetry. It is something permanent". (Apud PRATT, 2011, p. 43). "O imagismo é uma fase antiga da poesia. É algo permanente". Tradução nossa.

${ }^{285}$ Tradução nossa: "There is no doubt that Imagism was the means by which most of the masters of modern English verse discovered their own style, and in some sense every important poet of the 20th century was an Imagist, just as every important poet of the seventeenth century was a sonneteer".

${ }^{286}$ Conforme Pratt, muito dos experimentos posteriores realizados na poesia moderna de língua inglesa foram extensões do programa imagista original. No entanto, como afirma o crítico, a importância histórica do Imagismo só foi reconhecida após 1963, ano em que a primeira coletânea de poetas imagistas foi publicada - Imagism's “first comphrehensive collection", nas palavras do autor (PRATT, 2011, p. 42). 
denominou "One-image poem": poema estruturado ao redor de uma única e arrebatadora imagem dominante, seguida por uma sucessão ou justaposição de imagens relacionadas, cujo efeito maior é a sensação de instantaneidade.

No poema acima, "Natureza morta com frutos", a numeração dos dísticos parece claramente atender a essa motivação imagética. Os dísticos se estruturam ao redor de imagens autônomas e totalizantes, ais quais perdem o caráter ornamental ou de meros componentes do poema, para constituírem, como queriam também os imagistas, o próprio poema, ou seja, o fim e a razão de ser do poema. ${ }^{287}$ Embora a distinção da imagem pelos imagistas nem sempre seja muito clara ${ }^{288}$, Pratt a define da seguinte maneira:

Essencialmente, este é um momento que se estrutura em uma espécie de revelação da verdade, ao invés de uma série de eventos ou pensamentos consecutivos. $\mathrm{O}$ antigo argumento da poesia tradicional é substituído por uma imagem única e dominante, ou por uma rápida sucessão de imagens relacionadas: o efeito pretende ser antes instantâneo do que acumulativo. [...] Fundamentada na crença de que somente a imagem podia comunicar sentido, a poesia imagista

\footnotetext{
${ }^{287}$ Toda a base da teoria imagista encontra-se no pensamento de T. E. Hulme, conforme explica William Pratt: "The nature of this change [in the sense of metaphor, and in the perception of the relation of language to meaning] was first defined in a lecture on 'modern' poetry which T.E. Hulme gave to the group that formed the first 'School of Images'. He suggested that 'modern' art, as it was then emerging, was different from the art in the past in that 'it no longer deals with heroic action, it has become definitely and finally introspective and deals with expression and communication of momentary phases in the poet's mind.' He explained that the 'mystery of things' was no longer perceived as 'action' but instead as 'impression' [...]. He meant that the poetic technique should become subtle enough to record exactly the momentary expressions - the images, as he liked to call them - which were the real substances of experience. [...]" (PRATT, 2011, p. 31). Assim, as formas poéticas, para Hulme, deveriam responder mais diretamente ao controle interno da impressão ou imagem, do que ao controle externo de modelos e acentos preestabelecidos. Hulme ainda sustentava que a única e real comunicação entre os homens se dá apenas por meio de imagens: "Thought is prior to language and consists in the simultaneous presentation to the mind of two different images. [...] All language, according to Hulme's view, originates in wordimages, and in all real communication, 'each word must be an image seen, not a counter.' But by natural decay, words lose their significance as images, and so cease to communicate - unless revived by fresh associations and unexpected combinations. In the poetic use of words, language is restored to communicative power, by being infused with new images" (PRATT, 2011, p. 34).

${ }^{288}$ Os imagistas por vezes defendiam noções vagas daquilo que parece, a nosso ver, qualidades instintivas buscadas por todos os praticantes de poesia, de todas as épocas e movimentos, embora consigam dar a essas qualidades maior ênfase e concentração. Assim, a "imagem" dos imagistas parece apenas diferir do "símbolo" dos simbolistas na questão da precisão, como afirma René Taupin (The Influence of French Symbolism on Modern American Poetry. New York: AMS Press, 1985): "The pleasure in the imagist poetry is not the satisfaction of discovering little by little, but of seizing at a single blow, in the fullest vitality, the image, a fusion of reality in words" (TAUPIN, 1985, p. 96). Os imagistas reagiam, pois, aos princípios do vago, do difuso e do sugestivo, buscados pelos simbolistas, e insistiam no tratamento concreto, realista e direto da imagem, não como se ela fosse parte do poema, como acontecia no simbolismo, mas como se representasse o fim e propósito mesmo do poema. Segundo Pratt: "[...] Imagism was chiefly a movement toward making the poetic figure - be it simple metaphor or complex symbol - more definite and more real. The Imagists experiments were based on the belief, expressed in Pound's "A few don'ts of an Imagiste" in 1913, that 'the natural object is always the adequate symbol"" (PRATT, 2001, p. 39).
} 
almejava uma completa objetividade, deixando de lado todo comentário moral ou racional. [...] o conteúdo humano é antes sugerido do que dito. Sugerido na escolha das imagens, e no tom em que a imagem é tratada. [...] Os poemas imagistas, assim como o haiku, eram feitos para serem lidos e relidos, até que o significado da imagem pudesse ser transmitido.

(PRATT, 2011, p. 36) ${ }^{289}$

Acreditava-se que a imagem podia apresentar, na força de um único instante, todo um complexo intelectual e emocional, como explicava Ezra Pound ${ }^{290}$ : “[...] O preciso instante em que algo externo e objetivo se transforma, ou se torna algo interno e subjetivo" (PRATT, 2011, p. 37). ${ }^{291}$ Para alcançar a imagem esperada, os imagistas também estabeleceram princípios e etapas claras do processo poético a serem respeitados, em que se visava ao máximo rigor e trabalho de lapidação:

[...] Neste comentário há a elaboração de todos os princípios imagistas - começando com uma imediata e arrebatadora imagem visual, seguida pela formação de uma série visual ou padrão de cores na mente, e depois, pela procura das palavras exatas que expressam toda a impressão; o esforço deliberado para concentrar-se, e finalmente a utilização de um modelo poético estrangeiro a fim de que se produza e se cristalize a forma definitiva do poema.

(PRATT, 2001, p. 38) ${ }^{292}$

\footnotetext{
${ }^{289}$ Tradução nossa. "Essentially, it is a moment of revealed truth, rather than a structure of consecutive events or thoughts. The plot or argument of older poetry is replaced by a single, dominant image, or a quick succession of related images: its effect is meant to be instantaneous rather than cumulative. [...] Imagist poetry aimed at complete objectivity, leaving out all rational and moral comment, for behind it was the belief that only the image communicates meaning. [...] The human content is implied rather than stated. It is implied in the very choice of the image, as well as in the tone with which the image is treated. [...] Imagist poems, like the haiku, were meant to be read and re-read, to be mediated upon, until the full significance of the image had communicated itself'.

290 "An image is that which presents an intellectual and emotional complex in an instant of time. [...] It is the presentation of such a complex instantaneously which gives the sense of sudden liberation; that sense of freedom from time limits and space limits; that sense of sudden growth, which we experience in the present of the greatest works of art". Ezra Pond. "A few don'ts by an Imagiste" (Apud PRATT, 2001, p. 26).

${ }^{291}$ Tradução nossa: "The precise instant when a thing outward and objective transforms itself, or darts into a thing inward and subjective".

${ }^{292}$ Pratt se refere principalmente ao texto "Vorticismo", de Ezra Pound, publicado na revista Fortnightly Review, pp. 465 a 67. Tradução nossa: "[...] There is in this account the working out of all the Imagist principles - beginning with a sudden striking visual image, then the forming of a 'visual cord' or pattern of colours in the mind, then the search for the exact words to express it, the deliberate effort at concentration, and finally the use of a foreign poetic model to produce the crystallization that becomes the finished poem".
} 
Se observarmos com atenção o poema acima, "Natureza morta com frutos", de Eugénio de Andrade, identificamos vários dos princípios imagistas, sobretudo na concentração da forma, na descrição concreta e objetiva das imagens, no jogo de cores, na influência do haikus japoneses ${ }^{293}$, na representação do instante ${ }^{294}$. Pelo contraste das cores e pela predominância visual, é possível identificar um intertexto com o famoso “L'art, 1910”, de Ezra Pound:

\section{L'art, 1910}

Green arsenic smeared on an egg-white cloth, crushed strawberries! Come, let us feast our eyes. ${ }^{295}$

O poema de Pound estabelece uma reflexão, talvez um tanto satírica, sobre a arte moderna, através dos contrastes entre as cores do "arsênico" e do "morango", e convida o espectador para o banquete "visual", tão prazeroso e sensual, como sugere a presença da fruta, quanto dolorido e terrível pela presença do veneno. A breve imagem contém uma complexa rede de contradições, suscitando no leitor uma série de associações díspares, que abarcam tanto os sentidos quanto o intelecto. Desse modo, pela concisão na descrição de apenas uma imagem arrebatadora e enigmática, o poema pretende deixar ao leitor o trabalho de interpretação, lançando uma impressão forte mediada pela fusão de realidades e tempos diferentes que o morango esmagado e o arsênico derramado (aqui elementos narrativos tácitos) parecem evocar. Todos os tempos estão presentes, como podemos ver, na cena da mesa com a toalha branca, prestes a receber seus hóspedes para o banquete.

\footnotetext{
${ }^{293}$ Influência, muitas vezes, indiretamente sentida, já que concentrada apenas no tratamento da imagem. Nem o poema eugeniano acima nem os poemas imagistas de maneira geral pretendiam seguir estritamente o modelo clássico do haiku japonês, formalmente composto de dezessete sílabas, cujos temas e imagens se restringem, quase exclusivamente, à vivência da natureza. $\mathrm{O}$ mesmo acontece com influências da lírica grega e medieval. De acordo com Pratt, o poema imagista não é "exótico" nem constitui apenas uma tradução desses modelos antigos, já que seus temas podem provir diretamente da experiência urbana e cosmopolita do homem moderno (Cf. Pratt, 2011, p. 36).

${ }^{294}$ Para citar um exemplo, transcrevemos aqui um haikai de Bashô: "O mar escurece / a voz das gaivotas / quase branca", traduzido livremente por Paulo Leminski. Apud "A trilha errante do haikai". Alberto Marsicano. Trilha estreita ao confim. Bashô. São Paulo: Editora Iluminuras, 1997, p. 83. Note-se que alguns poemas de Eugénio se estruturam ao redor de imagem selhante, como o poema "Arima" do livro anterior (ANDRADE, 1966, p. 199), analisado acima. De Ostinato rigore, citamos o poema "Quase um Haikai", décimo segundo do livro, por conta da forma e concisão: "Que terror te ergueu / pétala a pétala / para eu desfolhar, / ó manhã de oiro!” (ANDRADE, 1966, p. 221).

${ }^{295}$ Ezra Pound. Personae. NY: A new directions books, 1990, p. 118.
} 
O poema de Eugénio de Andrade, composto em uma espécie de mosaico estruturado ao redor de uma única imagem dominante, a do "fruto amadurecido", também reúne como que pequenos aforismos poéticos, que oferecem uma reflexão sobre a arte poética eugeniana, principalmente no encontro simbiótico de oposições, na interação entre o "vermelho" da "framboesa" e a "brancura" do linho (verso que remete mais diretamente ao poema de Pound, em que um fruto vermelho também se encontra esmagado na toalha branca da mesa, embora no poema de Pound a fusão seja mais violenta e trágica do que no poema eugeniano, em que a cor da "framboesa" simplesmente "ama" a "brancura do linho"), ou no "sol e a lua" de "mãos dadas" na "laranja", ou seja, no "amor" entre todos os elementos.

$\mathrm{Na}$ descrição objetiva dos frutos estão presentes duas dimensões, em que o mundo exterior descrito pelo poeta simultaneamente remete a seu próprio mundo interior. A sobreposição de imagens visuais e também conceituais cria uma densidade de significados. ${ }^{296}$ Os dísticos nos dão imagens plásticas e concretas de frutos em repouso, como sugere o título, "Natureza morta com frutos".

O título, na verdade, surge como um paradoxo, já que os frutos no poema estão vivíssimos. O termo "natureza morta" - empregado nas artes plásticas para designar quadros que retratam objetos em repouso, possibilitando a contemplação das cores, formas e tessituras desses objetos, ao mesmo tempo em que apresentam um estudo da

\footnotetext{
${ }^{296}$ Trecho inspirado nas palavras de Stephen Reckert. Para além das neblinas de novembro: perspectivas sobre a poesia ocidental e oriental. Lisboa: Fundação Calouste Gulbenkian, 1999, p. 52. Reckert estabelece uma "poética minimalista", ou "poética do micropoema" em exemplos colhidos tanto do Extremo Ocidente, como a poesia lírico-trovadoresca, quando do Extremo Oriente, como a poesia de Li Po e os haikus japoneses. O crítico atravessa um extenso corpus para descrever alguns dos procedimentos desses micropoemas e encontra diversos pontos em comum entre eles, como a brevidade e a concentração da forma, a "estruturação paralelística", a "equivalência simbólica" (em que o poeta utiliza um símbolo já bastante conhecido no lugar de um referente qualquer, suprimindo os termos de comparação), a "sobreposição complexa de imagens visuais e conceituais", etc. Todos esses métodos tinham como função promover maior profundidade e densidade ao poema. Os imagistas enxergaram, como parece, já que se voltaram para esses mesmos modelos descritos por Reckert, o potencial imagístico do micropoema, principalmente no sentido de alcançar uma pluralidade de significados que pudessem expressar, de maneira mais efetiva, a experiência moderna. Embora o Oriente valorize a eliminação como via para a perfeição, como explica o crítico, em concordância com o ideal taoísta do vazio e do silêncio, (ao passo que os critérios do ideal poético ocidental são geralmente mais quantitativos), Reckert descarta tal geografia na determinação da poética minimalista. Para o crítico, o "Oriente não é tanto uma região como um estado de espírito: o da sociedade rural tradicional em oposição à urbana e tecnológica, que nasceu no Ocidente e aí se desenvolveu." (RECKERT, 1999, p. 82). Ou seja, foi no campo que nasceu a poética minimalista, seja no Oriente, seja no Ocidente. Nesse sentido, a poesia de Eugénio de Andrade é propositadamente minimalista, sobretudo por conta de seus ideais de simplicidade do campo e forte ligação com a terra, como temos visto desde o texto inaugural de Poemas, denominado "Poética". Porém, não devemos perder de vista a relação da poética eugeniana com leituras mais modernas dessa mesma poética minimalista, como as realizadas por poetas da Geração de 1927 na Espanha, pelos Imagistas anglo-saxões, pelo modernismo pessoano em Portugal, pelos surrealistas, etc.
} 
composição - transpõe-se para o poema com sentido semelhante, já que nele, Eugénio de Andrade também procura manifestar o repouso de um instante, e estabelecer uma reflexão sobre sua arte poética. No entanto, assim como a leitura satírica de Pound da composição artística moderna, o poema de Eugénio de Andrade poderia parodiar este termo técnico das artes plásticas, como se ele não pudesse, talvez, dar conta de significar as profundas contradições implicadas em toda composição artística.

Em inglês, o termo usado para esse tipo de pintura é "Still life", que talvez conseguisse remeter melhor à ideia de repouso que Eugénio de Andrade procurou manifestar no poema, repouso obtido principalmente através da escolha de alguns verbos como "debruçar”, “dormir”, e também “amar”, uma vez que este último aponta para o apaziguamento de oposições; para o encontro e a fusão das substâncias.

As imagens fragmentárias dos frutos em diversas situações nos transmitem a sensação de simultaneidade. Os frutos, ainda que recortados, comunicam plenitude. Todos eles são tipos de frutos colhidos no verão, conforme nomeia o quarto dístico: "Cada bago de uva sabe de cor/ o nome dos dias todos do verão" (ANDRADE, 1966, p. 220).

Assim, o "verão" mobiliza, neste livro, outros signos, como a "luz", a "terra" e os "frutos", agora já maduros. Se no primeiro livro da coletânea, os "frutos" colhidos pelas “mãos” não eram nomeados - a não ser em um único poema, "cerejeira em flor"-, em Ostinato rigore, eles todos se caracterizam por darem no verão, estação a qual, por sua vez, corrobora com a ideia de repouso, ou apaziguamento da ação do tempo reunião do "sol e da lua" no gomo de uma "laranja".

É nesse contexto, logo, que, desde o poema de abertura, o "verão" fulminante invade o poema, conferindo um estado de presentificação total, em que todos os elementos, metaforizados pelos signos recorrentes, se integram de maneira simbiótica, permitindo ao leitor vivenciar a sensação de continuidade ininterrupta nas mais diversas combinações entre os quatro elementos fundamentais:

\section{Os frutos}

Assim eu queria o poema: fremente de luz, áspero de terra, rumoroso de águas e de vento.

(ANDRADE, 1966, p. 219) 
Desse modo, experimentamos contiguidades entre o "vento" (ar) no tremer da "ave" e no "rumor" das "folhas". A "água" no correr do "rio", da "fonte", do "mar" - e por sua vez, na "espuma", na "areia", na "concha", nas "dunas", no "barco", no "mastro": "o que sei de ti foi só o vento / a passar nos mastros do verão" (1966, p. 230). O "fogo" na "luz", no "relâmpago", nas "estrelas", no "verão". E a "terra" nos "frutos", na "flor", nos "animais" e no "corpo" - este, tão presente em a toda obra, a interagir também, por seu turno, com a "água" do "rio" ou do "mar":

\section{Anunciação da alegria}

Devia ser verão, devia ser jovem: ao encontro do dia caminhava como quem entra na água.

Um corpo nu brilhava nas areias - corpo ou pedra, pedra ou flor?

Verde era a luz, e a espuma do vento rolava pelas dunas.

De repente vi o mar subir a prumo, desabar inteiro nos meus ombros.

E aprendia a falar na tua boca, mordendo cada palavra de alegria.

Sem muros era a terra, e tudo ardia.

(ANDRADE, 1966, p. 213)

Em contraste com o último poema de Mar de setembro, "Que diremos ainda", em que os amantes, à beira-mar, presenciavam o fechar do "céu" sobre as "dunas" e os "barcos" - e a "luz" a minguar (1966, p. 201) -, o "verão", neste poema, é total sobre esses mesmos elementos da paisagem e sobre um "corpo nu" que brilha nas "areias". Naquele poema, a atmosfera era melancólica e o silêncio predominava, ao passo que, neste, anuncia-se a "alegria" da união entre a "água", o "corpo", o "verão", a "luz", a "espuma", o "vento sobre as dunas". Aprende-se a dizer as palavras, e a "terra" não possui mais os "muros", que, desde As palavras interditas, apareciam como divisões da cultura, a organizar em padrões racionais os modos de vida, categorizando e excluindo o 
homem de sua própria inteireza. As palavras agora não encontram barreiras. $\mathrm{O}$ desejo flui e une o sujeito à paisagem: "tudo ardia".

Da mesma maneira que o poema acima, "Anunciação da alegria", outras oito composições do livro (em um total de trinta e dois por cento) nomeiam diretamente a "palavra" ou o "poema", incluindo o de abertura ("Eis como o verão entra no poema"), explicitando as relações de metalinguagem, quase sempre relacionadas à composição dos frutos e à combinação dos quatro elementos fundamentais, como vimos na análise acima de "Os frutos".

Em outras ocasiões, o poema ou a palavra surgem como objetos de esforço e labuta, referidos em termos de uma "arquitetura" em que a "cal", a "pedra", a "parede", os "muros", os "corredores" participam como elementos da composição, evidenciando o árduo processo de fabricação do poema, em que se transforma a matéria bruta (ou se transpõe as limitações desse processo, referidas por "muros", "corredores" e "paredes", como já demonstrado anteriormente) em substâncias etéreas como a "ave", a "luz", o "sonho", etc., como no metapoético poema "Metamorfose da casa", décimo terceiro do livro:

\section{Metamorfoses da casa}

1.

Ergue-se aérea pedra a pedra a casa que só tenho no poema.

2.

A casa dorme, sonha no vento a delícia súbita de ser mastro.

3.

Como estremece um torso delicado, assim a casa, assim um barco ...

4.

Uma gaivota passa e outra e outra, a casa não resiste, também voa.

5.

Ah, um dia a casa será bosque, à sua sombra encontrarei a fonte onde um rumor de água é só silêncio.

(ANDRADE, 1966, p. 222) 
Temos aqui uma súmula da dinâmica entre os signos a qual acompanhamos de maneira tão próxima ao longo de nossa análise de Poemas: a "casa" é também "barco", "corpo" e uma "gaivota"; gira em torno do "bosque", da "fonte", e da "água". O poema dá a ver a dinâmica rotatória dos "signos" à procura de significação; um "agora em perpétua rotação", como diria Octavio Paz (1982, p. 334), lançando-se ao infinito, e ao tempo futuro, como indicam os verbos da última estrofe. O silêncio é apontado como destino final do poema. No entanto, com o retorno ao silêncio pretende-se também um gesto de recomeço, em que o "rumor" da água pode ser lido como princípio de toda palavra poética.

O poema revela, por conseguinte, a consciência da moderna urgência do significado. A "casa", como já demonstrou Eduardo Lourenço, que a aproximou do lugar da aventura poética eugeniana (LOURENÇO, 1971, p. 46), poderia figurar também, de modo simultâneo, o "ser" e a "palavra poética": sempre móveis, transcendentes, concomitantes; em perpétua busca de sua própria imagem e sentido.

Assim, feita a partir da dureza de materiais como a "pedra", a "casa" do poema voa e consegue atingir máxima leveza, reportando-se à flexibilidade da palavra poética, capaz de manifestar e alcançar uma simultaneidade de vivências e sensações, transcendendo as divisões dos "muros", das "paredes", dos "corredores" impostos. O poema pretende saltar num retorno ao silêncio originário.

No fulgor imagético que temos acompanhado desde o poema de abertura de Ostinato rigore, reinstala-se, portanto, o "silêncio": a palavra atinge a plenitude, como demonstrava o poema "Nocturno de fão", a cantar, no mais alto dos "ramos", o "êxtase do dia" (ANDRADE, 1966, 224). O instante é vivenciado em seu ponto de combustão, também referido por "verão", ou por "ardor" e "dor", como no trecho final do oitavo poema do livro, "Nocturno a duas vozes". Nele, entabula-se um diálogo que parece ser entre dois amantes, ou talvez do sujeito consigo mesmo:

- Cala-te: as palavras doem.

Como dói um barco

ou um pássaro,

feridos

no limiar do dia.

Amo-te.

Amo-te para que subas comigo 
à mais alta torre,

para que tudo em ti

seja verão, dunas e mar.

(ANDRADE, 1966, p. 217)

Para além desse horizonte alcançado, composto por palavras que sugerem expansão, como "mar", "alta torre", "verão", e "limiar do dia", a mensagem só pode dissipar-se - no silêncio e na morte (“cala-te"), resultantes da entrega completa do sujeito ao fulgor da imagem, como também em:

7.

Onde espero morrer

Será manhã ainda?

(ANDRADE, 1966, p. 207) $)^{297}$

Esse dístico de "Cristalizações", segundo poema do livro, demonstra, talvez, a consciência de que a presentificação da imagem corre o risco de cair no silêncio e na tautologia. O verso poderia manifestar, além de outras questões mais pontuais, o conflito dialético que toda poesia enfrenta na procura pela imagem poética, a qual, isolada e instantânea, se oferece à custa da própria rarefação da linguagem. Ou seja, a tensão entre aquilo que Alfredo Bosi denomina "atomização" e "infinitude", como vimos na análise de Até amanhã: vontade de retração da linguagem como resistência ao fluir incessante do tempo e do discurso histórico, mas que esbarra em dificuldades da própria linguagem, corpo também vivo, tão subjetivo quanto social: "Abre-se em cada imagem um vazio - cheio de desejo ou de espera - que reclama a plenitude da relação" (BOSI, 1977, p. 34). Plenitude que se alcança ou não. Como temos visto, a poesia eugeniana não deixa de manifestar também toda a sua dor e frustração, ainda que consiga, como nos trechos acima, vivenciar a morte como transformação, ou seja, ainda que a poesia eugeniana consiga o efeito de transmutar a morte em "alegria" e "êxtase do dia”, num ato cheio de esperança. É para este esforço, talvez, que se dirige o título do

\footnotetext{
${ }^{297}$ Sétimo fragmento do segundo poema do livro, cujo título é sugestivo: "Cristalizações", ao qual pertence também: "4. Ama / como o rio sobe os últimos degraus / ao encontro do seu leito" (ANDRADE, 1966, p. 206).
} 
livro Ostinato rigore: pelo rigor obstinado, luta-se contra morte, procura-se a transmutação. O rigor obstinado inscreve uma luta. ${ }^{298}$

Desse modo, de maneira paradoxal, o dístico acima também expressa toda a esperança na capacidade afirmativa da linguagem e no potencial de "ruptura" ou "recomeço" que o poema moderno procura reinstaurar ao homem: "Será manhã ainda?" Essa esperança parece predominante em Ostinato rigore.

Como um guerreiro antigo ou soldado que na batalha se entrega à luta sob o risco iminente de morte - luta que se faz de uma espécie de jogo com a própria morte, em que morrer na batalha é, paradoxalmente, dominar a própria morte, já que lutar significa vencer a si mesmo, domando o sentimento de "medo" e "cobardia", para poder, com honra, pôr-se à altura da morte - da mesma maneira, a palavra, em Ostinato rigore, é referida, muitas vezes, por "dardo", "espada", "luz de metal”. Nessa dimensão de luta e máximo esforço, a "dor" e o "ardor” também se fazem presentes:

\author{
Mitologia \\ 1. \\ A noite quebra as lanças uma a uma \\ na brancura dos muros e da espuma. \\ 2. \\ O dia apaixonadamente branco \\ cai ferido por um dardo no flanco.
}

(ANDRADE, 1966, p. 218)

Nesta que poderia compor uma cena da Ilíada, de Homero, a "noite" trabalha ou "luta" para que o "dia", à exaustão de ser, morra vencido: repouso no silêncio da imagem habitada. Conforme atesta o título, o poema imita narrativas mitológicas em que o "dia" e a "noite" surgem personificados para representar a passagem do tempo. O rigor, o esforço e o trabalho poético são metaforizados nessa imagem de batalha, em que mais uma vez se representa a palavra na passagem da noite para o dia - embora aqui, o “dia” só nasça para “cair”, “apaixonadamente branco”. Essa queda poderia estabelecer

${ }^{298}$ Segundo Aiello, “'Ostinato Rigore' é uma divisa utilizada por Leornardo Da Vinci que o poeta Eugénio de Andrade faz questão de usar sem tradução, na língua originária. Este título revela um programa, uma arte poética [...]. João Gaspar comenta o ensaio de Valéry: 'Introduction à La Méthode de Leonarde da Vinci', afirmando que o título da coletânea de Eugénio de Andrade refere-se também a este ensaio". A poesia de Eugénio de Andrade em tempo de metamorfose. Tese de Doutorado. Maria Lígia Martha Aiello. Bauru: Faculdades do Sagrado Coração, 1985, p. 110. 
uma reflexão sobre a fragilidade da condição humana, como acontece também ao fim do longo poema da Ilíada. ${ }^{299}$ O "rigor" aparece, ao longo dos poemas, como luta contra a fragilidade, por meio do qual o poeta obra em direção ao absoluto, a superar a morte; a vivê-la como transmutação.

A divisão e a concisão dos dísticos manifestam o equilíbrio conseguido, o controle total da energia poética obtido no fio da "lança" e na dor infringida pelo "dardo no flanco": obstinado rigor, força; equilíbrio entre entrega e controle, entre esforço e dor:

\section{Quase um haikai}

Que terror te ergueu

Pétala a pétala

Para eu desfolhar,

Ó manhã de oiro!

(ANDRADE, 1966, p. 221)

“Terror", por um lado, mas também domínio diante da morte: canto que se esgota, máxima entrega do ser - ponto em que a dureza, ou a aspereza, do "terror" torna-se leve como a "pétala" e a "manhã de oiro".

Essas transformações do "material bruto", representadas dentro de imagens metafóricas do trabalho poético eugeniano, apontam também para as conquistas e os conseguimentos estéticos evidentes em Ostinato rigore, livro em que a poética eugeniana demonstra consciência ainda mais apurada de seus próprios alcances e obstáculos. A confiança e a aposta na palavra poética revelam-se mais intensamente neste livro, resultantes de um longo processo de maturação desde As mãos e os frutos, cujas angústias e percalços temos acompanhado de perto.

Pelo rigor e domínio das formas estéticas ${ }^{300}$, manifesta-se a grande e última aposta na poesia: termo desse longo processo, que alguns críticos classificam como

\footnotetext{
${ }^{299}$ Ao fim da Ilíada, a cena do choro e do abraço entre os inimigos Aquiles e Príamo desponta talvez como a mais trágica de todo poema. Aquiles matou o filho de Príamo, Heitor, e agora abraça o velho que veio reclamar o corpo do filho. Juntos, choram e lamentam o destino cruel do homem, mero joguete dos deuses. A fragilidade do homem aparece ainda mais dimensionada em situações como a do poema, de luta, guerra e morte.

${ }^{300}$ Nesta profunda reflexão metapoética, muitos poemas de Ostinato rigore recebem, com uma pitada de ironia, títulos de formas poéticas, musicais ou artísticas, como os poemas acima, "Quase um haikai", "Epitáfio", "Natureza morta com frutos", "Soneto menor à chegada do verão", "Mitologia"; e ainda: "Pastoral", "Estribilhos de um dia de verão", "Nocturno a duas vozes", "Cante Jondo", "Epitáfio" e "Elegia de um fim de setembro".
} 
primeira fase da poesia eugeniana ${ }^{301}$. No contexto do livro, percebemos a intenção de conter as dúvidas mais frequentes diante da poesia:

\title{
Epitáfio
}

Barcos ou não

ardem na tarde.

No ardor do verão

todo rumor é ave.

Voa coração.

Ou então arde!

(ANDRADE, 1966, p. 233)

A partícula "ou não" revela uma porção de dúvida subjacente, mas subjulgada pelas afirmações seguintes, “Ardem na tarde" e "Todo rumor é ave”, pela presença do "verão" e pela exclamação "Voa coração. / Ou então arde!" As duas alternativas oferecidas pelo sujeito represam a dúvida e a hesitação; pretendem domar o "medo" e a "cobardia". Também a morte é, desse modo, gloriosa. O canto, mesmo que no espaço curto de um instante, pode ser a experiência de uma vivência total.

No próprio saber dessa entrega, percebe-se, no entanto, a chegada do fim, o esgotamento e a exaustão da imagem, presentes nos títulos dos poemas finais do livro: "elegia", "despedida", "exílio", “exorcismo". O vigésimo segundo poema do livro expressa toda a melancolia que subjaz ao sentimento de êxtase perante o auge da palavra poética:

\section{Sete espadas para uma melancolia}

\author{
Um corpo \\ para estender a náufragos - o teu corpo. \\ Um rasto de cadela aluadas, \\ um charco de maçãs apodrecidas \\ ou longas cabeleiras apagadas... \\ Não dizias palavras ou dizias
}

\footnotetext{
${ }^{301}$ Gastão Cruz, por exemplo, ao se referir a Obscuro domínio, primeiro livro posterior a Poemas, identificou transformações estilísticas e a "formulação de uma arte poética diversa, específica novidade" em relação aos livros anteriores. Em "Função e Justificação da Metáfora na Poesia de Eugénio de Andrade”. 21 ensaios sobre Eugénio de Andrade. Editorial Inova Porto, 1971, p. 130.
} 
só aquelas onde o rosto se escondia.

Palavras onde o sangue não abria

a corola de fogo à madrugada.

O azul não canta, a água morre

na mais secreta boca do teu corpo.

Aqui não brilha a terra, a luz é fria, aqui o horizonte não respira.

Não havia vento: só medo e cobardia.

(ANDRADE, 1966, p. 237)

Cada estrofe corresponde, numericamente, conforme indica o título, a uma "espada" na luta ou no labor poético contra a esterilidade da melancolia. A batalha aqui é, porém, em vão. A melancolia vence em cada uma das estrofes: "náufrago" na primeira e, depois, "cadelas aluadas", "maçãs apodrecidas", e assim por diante, até o domínio final do "medo" e da "cobardia".

A cena parece compor-se para além do tempo, em que não há "vento", nem movimento algum no espaço: a "água morre" e as "maçãs" já estão "apodrecidas". No horizonte dominado pelo medo, todos os objetos se encontram, assim, em repouso total, como que petrificados: os elementos intactos não podem encontrar-se, as "palavras" ditas não reagem, não desencadeiam o "sangue", o "fogo", a "madrugada" ou a "água".

Tudo representa isolamento e repouso. O vocabulário ecoa, ainda que muito indiretamente, outra cena de Homero, desta vez do canto XI da Odisseia, em que Ulisses visita o Hades, morada dos mortos. Lá, vagueiam apenas sombras ("rosto se escondia") dos homens e dos heróis desanimados, que só depois de beberem "sangue" poderiam voltar a falar, dizendo o futuro - no poema, verificamos também relações entre as "palavras" e o "sangue", embora ambos não se encontrem, nem reajam à presença um do outro. "Água morre" e "cadelas aluadas", bem como "maçãs apodrecidas" e "luz fria", também colaboram na composição desse cenário fúnebre, cercado pelo que poderia ser o Aqueronte, rio que transportava os mortos para a entrada do Hades, guardada por Cérbero, um cão de três cabeças.

A morte aqui representada não é gloriosa, já que o sujeito está entregue ao "medo" e à "cobardia", que petrificam os sentidos e os elementos do mundo. Ou seja, a 
morte neste poema é uma espécie de "apêndice sem substância e sem valor" ${ }^{302}$ da vida. A morte só é gloriosa quando vivida em seu potencial poético. Quando encarada pelo sujeito como contraponto necessário para que se viva, mais intensamente, a vida corpórea. Ou seja, quando colabora como potencial de transformação. O risco da morte, se enfrentado com consciência, intensifica a relação do sujeito com os sentidos e com a percepção do mundo.

Neste poema, portanto, a morte guarda relação apenas com o esgotamento da palavra poética e com a esterilidade dominante. Lamenta-se a ausência de vida na visão de um corpo estendido.

Entretanto, na dialética central da poesia eugeniana, a esperança também desponta, e o vigésimo quinto poema do livro, posterior a "Sete espadas para uma melancolia" e último do livro, reacende na "púrpura do fogo" e no "rosto do verão" a confiança no que poderia ser na palavra poética:

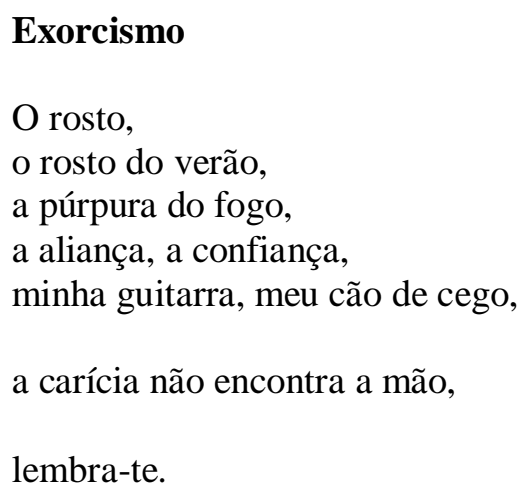

(ANDRADE, 1966, p. 240)

Se, naquele poema, o "rosto se escondia", neste, ele se mostra, em associação com o canto, como a lorquiana "guitarra" indica, e com a "luz" do "verão" e do "fogo". A imagem "cão de cego" também parece significativa, pois poderia remeter à aventura poética eugeniana, muitas vezes aludida pela busca no escuro, ou por um mover entre caminhos hesitantes e inquiridores, como nos versos do prefácio de As palavras interditas: "Que posso eu fazer senão escutar o coração inseguro dos pássaros, encostar a minha face ao rosto lunar dos bêbados e perguntar o que aconteceu" (ANDRADE, 1966, p. 97).

${ }^{302}$ Expressão de Teodoro Rennó Assunção. "Ulisses e Aquiles repensando a morte: Odisséia XI, 478 491”. Kriterion: Revista de Filosofia. Vol. 44. N. 107, BH: junho, 2003. 
Todavia, o verso fragmentado da estrofe principal: "a carícia não encontra a mão" surge como um contraponto enigmático, a lamentar certa falta, certa impossibilidade de encontro poético ou amoroso, centralizado no signo da "mão". Bem diferente, portanto, da imagem no poema de abertura de Poemas: "só as tuas mãos trazem os frutos [...] / são elas são / estrelas penduradas nos meus dedos / - Ó mãos da minha alma, flores abertas aos meus segredos!” (ANDRADE, 1966, p. 17).

Por outro lado, o poema acaba no fragmento "lembra-te", o qual, pela concisão e pela quebra, apenas sugere, no silêncio que ele inicia, um imperativo enigmático, ao modo da inscrição no oráculo de Delfos "Conhece-te a ti mesmo": é preciso lembrar da "luz" quando ela já se extingue. Do "rosto" quando já parte. O poema canta a morte e resiste. Desfecha com a esperança depositada na memória, capaz de lutar contra a morte e o esquecimento, ainda que a palavra subsistente ("lembra-te") seja muito pequena e fragmentada, diante do silêncio que nasce imenso, ao redor do verso. 


\section{CONCLUSÃO}

Wolle die Wandlung ${ }^{303}$

(Rainer Maria Rilke, 1922)

Ao acompanharmos algumas das principais linhas de desenvolvimento da poesia eugeniana, identificamos, ao longo da dança dos signos, uma série de tensões por meio das quais Eugénio de Andrade vai compondo sua arte poética.

A partir da leitura do prefácio "Poética", pudemos constatar a tentativa de síntese consciente da visão tradicional de mundo - do homem ligado à terra, aos frutos e aos costumes -, e das conquistas da poesia moderna, sobretudo nos modos como se procurou inovar a linguagem a fim de que ela pudesse continuar a dizer e a enfrentar os dilemas do homem moderno. Em detida análise das imagens, vimos, portanto, o diálogo que o poeta estabelece com a escrita moderna, desde Mallarmé e Camilo Pessanha, por exemplo, até os poetas imagistas e a escrita surrealista, sem deixar de incorporar elementos do cancioneiro nacional; das kharjas e cantigas populares; da tradição mediterrânea - como a lírica greco-latina ou a poesia espanhola -; e ainda as formas da poesia oriental, como o haiku. De maneira bastante própria, Eugénio de Andrade se insere na linhagem dos poetas modernos que buscaram no passado fontes e vivências alternativas, com o propósito de alimentar as leituras e o cotidiano cada vez mais empobrecido do homem moderno e citadino.

Na circularidade: "homem, terra e palavra", assinalada desde o prefácio, percebemos as imbricações entre o projeto político e estético de Eugénio de Andrade. Ficou claro que ler sua poesia implica não só apreciar, mas também pensar com as palavras e a partir das palavras, na medida em que elas desorganizam o discurso já viciado e cada vez mais hegemônico com o qual nos habituamos a considerar o mundo. E na medida em que elas também ensaiam, na "rotação dos signos", uma tentativa sempre inacabada de recomposição, por meio de um modelo de espaço e tempo em movimento constante.

Assim, a escrita eugeniana expõe ao leitor todo o seu processo ${ }^{304}$, atualizando, na leitura, as dissonâncias que são vivenciadas no ato da escrita - criadas no embate

\footnotetext{
${ }^{303}$ XII Soneto de Die Sonette an Orpheus, Zweiter Teil . "Queiram a transformação”. Tradução nossa. Cf.http://www.sternenfall.de/Rilke--Die_Sonette_an_Orpheus--Zweiter_Teil--XII-

Wolle_die_Wandlung.html (acesso 15/10/2012).

${ }^{304}$ Vale dizer que a escrita eugeniana expõe ao leitor seu processo de modo figurado, apontando para a origem do ato poético sempre por meio de imagens e metáforas, como a presença marcada da "luz" e do
} 
com os sentidos cristalizados, na negociação com as incongruências, no "obstinado rigor" das formas. A "rotação" dos signos constantes trabalha modulações de sentido na própria repetição, fazendo do leitor um agente participativo na composição dos significados possíveis - na contramão de uma realidade histórica que se fundamenta, quase sempre, na passividade diante da dificuldade do sentido, da memória e da comunicação.

Nesse contexto, os poemas organizam uma espécie de condução narrativa que, embora ondulante, repleta de idas e vindas e hesitações, compensa, de certa maneira, a dificuldade geral da linguagem imagética em coadunar sentidos mais duradouros, sobretudo como crítica e combate aos problemas muitas vezes urgentes da realidade histórica imediata. Percebemos, portanto, na poesia eugeniana, a oscilação consciente entre o repouso atemporal na imagem - presença irradiante da simultaneidade que estilhaça a linearidade do tempo histórico, decompondo os sentidos mais fixos -, e a reflexão sobre esse mesmo processo, frequentemente acompanhada dos queixumes de um sujeito poético que se sente esgotado.

A movimentação entre os signos impõe, por conseguinte, o agrupamento de poemas em unidades mais abrangentes, permitindo entre eles duplo movimento: de um lado, a radical concentração da imagem, constantemente atualizada na rotatividade dos signos, e de outro, a superação crítica do próprio desgaste imagético. Tensão que também se faz entre silêncio e fala, imagem e discurso, êxtase e melancolia, ou entre a intensificação do instante presente e as sujeições do tempo histórico.

Entre os "signos em rotação", surge, assim, um tecido de associações e recorrências em constante reorganização, de modo que cada nova "variação" desperta uma série de ressonâncias dentro de um mundo reconhecível. Assim, diferentemente da exaltação da mudança na modernidade, em que a "novidade" apresenta, a cada vez, um novo desligamento, na poesia de Eugénio de Andrade a mudança não constitui uma interrupção propriamente dita, mas um novo encontro. No mundo dinâmico da poética eugeniana, todos os elementos participam entre si e cada transformação está radicada na continuidade entre as substâncias. A mudança passa a ser exaltada exatamente porque

\footnotetext{
"rumor", por exemplo, lidos como unidades elementares da palavra. O poeta perseguia um rigoroso acabamento dos poemas, e, nesse sentido, se distancia, por exemplo, da escrita surrealista, que procurava expor ao leitor os processos ditos "inconscientes" da escrita, anteriores ao trabalho de acabamento, explicitados em exercícios de "escrita automática" ou nos projetos coletivos dos "cadáveres esquisitos".
} 
ela permite a continuidade entre os elementos. A palavra poética restitui ao homem um espaço habitável, em que é possível religar-se ao mundo fenomênico.

Assim sendo, na movimentação constante da poesia eugeniana o leitor pode habitar criticamente a imagem, experimentando suas potencialidades tanto afirmativas quanto negativas, em que, por um lado, se buscam os sentidos "outros" e a transcendência da vivência histórica, mas que, por outro, também formula, através do autoconfronto crítico das imagens, uma reflexão sobre o esgotamento da palavra ante a dura condição do sujeito em seu momento histórico.

É diante desse quadro, portanto, que a poética eugeniana frequentemente se autoexplicita: pelo ímpeto de repisar os sentidos, a poesia e suas possibilidades. Eugénio de Andrade une de modo indissociável o "fazer" e o "pensar" a poesia - a um só gesto, crítica e fruição, ética e estética, amor e palavra. $\mathrm{O}$ ato poético é apresentado com o propósito ético de despertar o "homem no homem", como afirmado desde o prefácio "Poética" 305 . A escrita eugeniana convoca a vivência contraditória dos mais diversos tempos coadunados pela poesia: da memória, da história, do corpo, da imagem, dos ciclos da natureza, da consciência, do sonho, etc.

Dessa maneira, no primeiro livro, As mãos e os frutos, amiúde encontramos encenado o nascer da poesia, referida diversas vezes por "canto". Dos sete livros da coletânea, talvez seja este primeiro, juntamente com o último, Ostinato rigore, o volume que mais evidentemente reclama a leitura do conjunto, circunscrita a signos recorrentes e a escolhas que ditam o ritmo circular do livro. $\mathrm{O}$ fato de somente vinte e cinco por cento dos poemas conterem títulos contribui para a inserção das composições nessa dinâmica mais abrangente, em que os signos ficam a vibrar, em seu conjunto, contra o que pressentimos ser o silêncio anterior e posterior ao "canto". Cada signo recorrente - os principais, entre eles, "mãos" e "frutos" do título, assim como "ave", "noite", "rio" e "fonte" - participa de núcleos expansivos, que, embora suscitem uma variedade de temas e assuntos, encontram-se amarrados por um eixo comum: o anúncio do "canto" amoroso.

O "canto" percorre, desse modo, diversos ciclos ondulantes que narram desde a apreensão do poético - metaforizado ora pelo "fruto" maduro que se oferece à "mão" (poema 1), ora pelo gesto anímico do "rio" que "canta" (poema 2), ou pela "ave" que

305 "É contra a ausência do homem no homem que a palavra do poeta se insurge" (ANDRADE, 1966, p. $10)$. 
"renasce da sua morte" (poema 3) - até a própria produção do poético, em que se evidencia a fabricação da palavra pelo sujeito, como no poema 23 , “A uma cerejeira em flor", em que encontramos uma total coincidência entre o "homem" que escreve a palavra e a "árvore" que produz o "fruto"; ou no poema 28, em que o "rio" se mistura ao "corpo" do sujeito que canta; ou no poema 24, em que os "gestos" do sujeito poético são "aves" a se transformar: "A cada gesto que fazemos / cada ave se transforma noutro ser" (ANDRADE, 1966, p. 43).

Sob influxos amorosos, esses ciclos ondulantes se entrecruzam e narram, através de tensões, o irromper e o desgaste da palavra poética, que, em contiguidade com um amor que definha, sucumbe como "frutos" podres no chão. Assim, o "fruto" apodrece, o "rio" corre descontrolado e a "ave" perde-se no voo. Embora a mudança seja apregoada pela poética eugeniana como fundamento de todo o entendimento da vida e do homem, seus poemas não deixam de lamentar, por seu turno, a dimensão trágica da passagem do tempo.

É nessa oscilação, por conseguinte, entre a celebração da mudança e a dor que ela acarreta, e entre a afirmação da poesia como resistência e a hesitação em face de suas potencialidades que a poesia eugeniana segue em seu trabalho de transubstanciação, fabricando a "semente" que salta do fruto apodrecido logo no primeiro poema do livro seguinte, Os amantes sem dinheiro. Desse modo, através do "modelo orgânico" do "fruto", a poesia eugeniana procura fundamentar-se no princípio da metamorfose.

No segundo livro, é o signo da "ave" que domina o processo de proliferação das imagens e das metáforas, delineando a movimentação geral da poesia eugeniana. A "ave" se insere no contexto da relação materna e conduz, pelo seu percurso instável ao longo dos poemas, a constituição do que parece ser a identidade do poeta, por meio da rasura do "retrato" que a mãe guarda do menino e das "rosas brancas": "Boa noite! Eu vou com as aves" (ANDRADE, 1966, p. 83). As "aves" possibilitam, assim, uma transferência no processo de constituição da poesia eugeniana: na origem, fortemente marcada pela influência materna, e agora em busca por novos caminhos, os quais aparecem como uma constante em todo o livro: "E então o que aconteceu foi maravilhoso: de dentro saiu um som bonito, mais bonito ainda do que a voz de minha mãe" (ANDRADE, 1966, p. 60). 
Além de formular uma identidade poética e figurar o papel da memória no processo constitutivo da poesia, a "ave" oferece também uma reflexão sobre a própria linguagem poética, apontando para sua ressonância mítica e para os resquícios de outro tempo em que o homem possuía uma dada imagem do mundo. O voo da "ave" permite, assim, um duplo movimento: desde a celebração da memória e o resgate de outras vivências alternativas até a leitura crítica desse mesmo ímpeto, afirmando contraditoriamente, a impossibilidade, no mundo moderno, de tal reconciliação. Temos, pois, que o voo da "ave" escapa aos gestos humanos, ao mesmo tempo que reafirma toda procura.

Em suma, do mesmo modo que o "fruto" é uma "imagem tornada verbo", para usar a expressão de Bachelard (BACHELARD,1990, p. 61), cuja presença - em condição de continuidade entre o primeiro e o segundo livro - é marcada pelo poema de abertura de Os amantes sem dinheiro, a "ave" também mimetiza a palavra poética, suscitando uma multiplicidade de sentidos e fazendo renascer, a cada gesto, o canto do silêncio.

Entre o segundo e o terceiro livro, As palavras interditas, há uma transição do signo da "ave" para o signo do "barco" ou "navio", o qual adquire status principal nesse volume: "Iluminou-se com a palavra exacta / que muda os cavalos em rios, / os rios em aves, / as aves na tua boca!" (ANDRADE, 1966, p. 102); ou: "Não é nada, meu amor, foi só um pássaro, / a casca do tempo que caiu, / uma lágrima, um barco, uma palavra" (ANDRADE, 1966, p. 103); ou ainda: "Um pássaro e um navio são a mesma coisa / quando te procuro de rosto cravado na luz" (ANDRADE, 1966, p. 114).

O "barco", assim como o "pássaro", é um signo em expansão: procura ao longo de todo o livro por uma saída, uma vivência alternativa ao "horizonte de cidades bombardeadas". À deriva, aparece assiduamente a flutuar entre duas "margens nuas": o ambiente noturno e desumanizado da cidade, por um lado; e à procura pelo encontro privado entre os amantes, por outro. Identificamos, assim, o movimento constante de revisão da poética eugeniana, que, mesmo pelo revés e pela tangente de um dizer "interdito", procura afirmar os poemas como um "ato" poético. Em condição de ilegalidade, o "navio-palavra" procura atravessar a cidade em ruínas, promovendo o fluir das "palavras interditas", aludidas desde o título do livro, encenando e reiterando, a cada movimento, o ato poético e a cena da escrita, apresentados como resistência à dura realidade histórica de um país submetido à ditadura. 
No entanto, verificamos, em muitos poemas desse livro, uma tendência marcadamente discursiva, em que se lamenta e se questiona, com angústia, o potencial de resistência das imagens poéticas. O tom geral é bastante pessimista.

O quarto livro, Até amanhã, afirma novas relações dentro da poética eugeniana, em que se formulam novos "nomes" para a contínua busca: "juventude", "corpo", "erótica". Nesse circuito erótico-amoroso, sua poesia se vale do léxico circunscrito, movimentado por uma complexa rede metamórfica, cuja inspiração principal é o "corpo" e seus domínios, em direção ao campo do maravilhoso, da quintessência, da unidade reconciliada, cujos signos da "luz", do "fogo", do "voo" e do "anjo" parecem evocar. Ao mimetizar a mobilidade da natureza, a metamorfose poética procura conduzir-nos à vivência da permanência e do infinito. A palavra poética, em constante transformação e abertura, capta, na brevidade das substâncias, a própria "eternidade", ou seja, o perpétuo refazer-se do "imediato", "substância impossível" tanto para os mortais quanto para os imortais, como dizia Hölderlin ${ }^{306}$, e por isso identificada como "puro divino", aquilo que está "por detrás dos deuses", nada mais sendo do que a “intensa sensação de estar vivo" (CALASSO, 2004, p. 34). O encontro com "Deus" dáse, portanto, na imanência da vida, no corpo, no homem, na terra e no ato de criação. A "luz" e o "fogo" conciliam domínios separados do "corpo" e da "alma"; da "razão" e da "revelação"; ou da "razão" e de uma dada "inspiração". Permitem uma reflexão sobre os domínios do poético, que procuram desfazer a vida compartimentada que racionalmente se impõe ao homem.

Tanto a "luz" quanto o "fogo", elementos contíguos na composição do signo central do livro, guardam profundas relações com o "pássaro", com o "barco" e, de certa maneira, com o "fruto", já que este também perpetua, como os demais, movimento de expansão e metamorfose. No movimento ondulatório dos signos, no ciclo aberto do "fruto", no expandir da "ave", no flutuar do "barco", na frágil ascensão do "fogo", a poesia eugeniana formula uma "poética do instante": em cada recomeço procura-se a plenitude da palavra, mesmo que na própria instabilidade dos elementos.

No entanto, é esse mesmo ímpeto de mudança que constitui, por sua vez, a fonte de angústia e de frustração que encontramos repetidamente expressos nos poemas eugenianos. Ainda que estruturalmente se fundamente na mobilidade entre os signos, sua poesia lastima a mudança, a constante flutuação do desejo, o desgaste da palavra, as

${ }^{306}$ Citado por Roberto Calasso. A literatura e os deuses. São Paulo: Companhia das Letras, 2004, p. 34. 
relações instáveis. A mudança também é fonte de inquietação para o sujeito moderno: desencadeia a sensação de esvaziamento e dissolução. O excesso de possibilidades sempre renovadas de escolha acaba por condenar o homem à decrepitude do desejo e à estagnação. Assim, o título do livro evoca aquela pergunta que tanto assola o poeta moderno: como fazer perdurar, Até amanhã, a imagem do homem reencontrado?

O quinto e o sexto livro da coletânea, Coração do dia e Mar de setembro, situam-se, predominantemente, nos domínios do signo móvel da "água", que se associa, no primeiro volume, ao tema da memória, da infância, do afeto maternal e suas ligações com o "canto"; e no último, ao desaguar no "mar", em que se mimetiza aquela que parece ser, talvez, a mais radical expansão da poesia eugeniana; linguagem em total abertura e processo de rarefação; correr em direção ao inefável; horizonte de silêncio, ser em expansão.

Desde os primeiros poemas da coletânea, em que o universo de solidão e tristeza do eu lírico é interrompido pela chegada do amado, observamos o elemento "água" associado ao "canto" ou a uma "espécie de música" (para empregar a expressão de Óscar Lopes ${ }^{307}$ ), nascida do ritmo amoroso e dos elementos em anelo, que encanta a linguagem, provoca o fluir contínuo de imagens, metaforizado, muito frequentemente, pelo fluxo do "rio". O "rio" é, no decorrer de todo As mãos e os frutos, comparado, por exemplo, ao corpo do amado, cuja chegada põe fim à "secura" vivenciada pelo sujeito. A “água” figura a pulsação original de todo encontro e convergência dos elementos. Seu ritmo faz nascer a poesia, correspondência traçada em versos como: "Para ti rasguei ribeiros / e dei às romãs a cor do lume" (ANDRADE, 1966, p. 25).

Em Coração do dia, a "secura", dentro do cenário atual de solidão do sujeito, identifica-se, da mesma maneira, com o silêncio ou ausência do canto. Logo, é possível estabelecer uma correspondência, ainda que às vezes indireta, entre o anseio pela "água" e a evocação de uma espécie de "ritmo" poético ou "música" longínqua, a sobrepor a ausência e o silêncio estéril, de alguém que se sente cada vez mais abandonado, principalmente diante da morte da mãe, à qual esse quinto livro é dedicado.

A escrita eugeniana procura recuperar, desse modo, o elo que se pressente em dissolução. Óscar Lopes (2001) examina o esquema enunciativo de Coração do dia e o define como, pela primeira vez na poesia eugeniana, "suplicante" do sujeito poético em

${ }^{307}$ Expressão emprestada do livro de ensaios, já citado e bastante conhecido, de Óscar Lopes, sobre a poesia eugeniana (2001). 
relação ao "tu" objeto de desejo. Embora a questão transcenda a relação materna, já que o eixo eu-tu - assim como a movimentação dos signos e das metáforas - permanece em “interpelação constante", evidenciando a precariedade da representação e a instabilidade dos significados, a indagação mais direta pelo tu exprime um novo abalo, sem precedentes nos livros anteriores, que parece ser motivado, pelo menos em uma primeira instância, pela morte da mãe, tema principal do livro. O abalo é transposto para o pensar de sua poética, que agora se indaga sobre o problema da recepção de sua arte e sobre a possibilidade de a poesia perdurar diante de um "tu" cada vez mais oblíquo e mais distante. A "água" desponta como elemento diluidor, mimetiza a "lenta diluição dos ritmos vegetais e minerais" (LOPES, 2001), até a impossibilidade de diferenciação da matéria. Nesse fluir tranquilo e sem dor, encontram-se o sujeito e a mãe.

A “água” espelha a contínua busca humana pela própria imagem, sempre móvel, e transcendente. Em sua infinitude e profundidade, é também linguagem em movimento. Como acontece também com os outros signos recorrentes, na "água" reside o gesto de recomeço. No seu fluir metafórico, procura-se a libertação da imaginação das amarras do discurso, do encadeamento lógico, da vivência histórica e temporal. Pretende-se reverter, assim, o sentido usual.

Inserido nessa mesma sintaxe do fluir, em que a "água" assume o estatuto de um destino, Mar de setembro promove o desaguar de todo movimento no ir e vir constante do "mar", signo central do livro, cuja recorrência permite grande concentração imagética, em que se experimenta a sensação de refração e simultaneidade. Seu ritmo constante "beira o silêncio absoluto", instalando a indissociação entre ir e vir, fim e começo, nascimento e morte, música e silêncio. Como grau minimal em agitação permanente, o "mar" trabalha a duração e a intensidade, permitindo a justaposição de planos espaciais e temporais. Funciona como sinédoque do espaço abrangente, porém incerto do poema, que se pretende total, para onde tudo conflui e o instante se concentra.

Assim, o "mar" é, talvez, o signo mais emblemático da poética eugeniana. Com ele, mantêm proximidade quase todos os signos recorrentes que observamos em Poemas: a "ave" em Os amantes sem dinheiro sobrevoa o "mar" em diversos poemas. O "barco", em As palavras interditas, também admite uma leitura que se relaciona, metonimicamente, com esse signo; assim como a "água", e também a "luz", sempre presente na descrição das paisagens marítimas. Além do mais, em seu ir e vir infinito, o 
"mar" poderia mimetizar os movimentos conflituosos da poética eugeniana: errante por um lado, a permutar os signos ad infinitum, num mover sem cessar que vai transformando a substância do ser. Para essa poesia, a vida toda é imóvel e o instante luminoso só pode ser capturado, como pura presença, em movimento e metamorfose. Mas se assumindo ainda como termo de chegada e horizonte do desejo. Como ponto de expansão e rarefação total da linguagem, o "mar" também desperta a consciência do grande vazio em que o homem navega, sem saber para onde veio e vai. Outra recorrência importante ao longo do sexto livro é a presença marcante de versos interrogativos em diversos poemas, os quais parecem propor novos caminhos, apresentando, assim como a figura do "mar", uma espécie de suspensão do sentido.

Dessa maneira, como já dito anteriormente, porém ainda mais evidenciado pela presença do "mar", o silêncio e o esvaziamento procurados no isolamento de uma dada imagem instantânea ou na própria rarefação da linguagem, em que se busca talvez cessar e reverter o sentido usual e histórico, pode também, por seu turno, dissipar-se até a própria morte da mensagem. O silêncio, gesto de recomeço tão procurado pela poesia moderna, é simultaneamente fértil e estéril. Por conseguinte, a hesitação e a angústia constituem, na poesia eugeniana, mecanismos críticos.

No sétimo e último livro da coletânea, Ostinato rigore, a presença do silêncio é ainda mais marcada pelo recorte epigramático dos poemas, o qual evidencia o difícil equilíbrio obtido pelo poeta entre a contenção da expressão e a expansão explosiva da energia poética, sugerindo, de outra feita, o conflito imanente entre entrega e superação da morte. O tema da superação pela poesia, seja da morte, do silêncio, seja do sentimento de melancolia, vencidos quando incorporados como material do poético, é recorrente em todo o livro.

Embora em Ostinato rigore seja mais difícil apontar apenas um único signo recorrente, reclamamos para o "verão" sumária importância, por metaforizar, como no poema de abertura, certo "termo de chegada" - solstício da palavra poética, movimento que já se aproxima do repouso e fusão. No entanto, os signos mais constantes da poesia eugeniana, desde o primeiro livro da coletânea, como "frutos", "luz", "ave", por exemplo, reaparecem de maneira bem entrosada, participando, do mesmo modo que em As mãos e os frutos, de diversos "ciclos" que se multiplicam e se interligam ao redor dos poemas, agora, porém, sob a luz mais madura do "verão". 
A poética eugeniana demonstra, nesse último livro, consciência ainda mais acurada de seus próprios alcances e obstáculos. A confiança e a aposta na palavra poética revelam-se mais intensamente, resultantes de um longo processo de maturação. Pelo "obstinado rigor" e domínio das formas estéticas, manifesta-se a grande e última aposta na poesia: termo desse longo processo, que alguns críticos classificam como primeira fase da poesia eugeniana.

Como tentamos demonstrar, embora Ostinato rigore se encontre estruturalmente ligado a As mãos e os frutos, reverberando os signos e os núcleos ondulantes apresentados por esse primeiro livro de Poemas - fato que reclamaria para a coletânea uma estrutura circular, já que o último livro retoma e encerra o primeiro, infundindo no leitor a tentação em ler essa poesia dentro de um quadro de coerência -, é importante ressaltar que a poética eugeniana se desenvolve, antes, por meio de oscilações, conduzindo o encontro do leitor com as imagens e os dilemas de Ostinato rigore diferentemente do modo como se apresenta no primeiro livro da coletânea. A poética eugeniana se autoformula no percorrer das mais diversas tensões, por meio das quais os signos e as imagens se movem e se confrontam em tonalidades opostas, espécie de claro e escuro, sempre distintas, mesmo que constantes: ora em expressão do deslumbre poético, do êxtase, da pureza e da inocência, ora da lamentação trágica, da contemplação melancólica, ou do ceticismo mais crítico e maduro. Ou seja, o sujeito eugeniano celebra e lamenta em todos os livros o amor, a passagem do tempo, a palavra, a morte; até que encontramos, de modo ainda mais marcado no último livro da coletânea, luminosa esperança.

Com isso, não defendemos uma evolução propriamente da poética eugeniana, uma vez que as diversas tonalidades convivem nos sete livros, transformando-se a todo instante, compondo uma estrutura não tão linear - embora conduza "proto-narrativas"nem, talvez, tão circular quanto pareça, principalmente ao mimetizar os ciclos da natureza; mas antes ondulante, como uma longa espiral que se desenha por meio de tensões e conflitos, e que impõe a mais sutil mudança na própria repetição dos termos. Cada poema, inserido nessa dinâmica espiral, torna-se o lugar simultaneamente esvaziado e pleno, que possibilita ao homem a conquista de seu ser, a realização de suas potencialidades e a transcendência de sua condição. 
Para concluir, foi possível analisar todas as etapas de autoformulação da poética eugeniana por meio do cotejo com o modelo apresentado por Lubomir Dolezel, estruturado a partir de uma themata fundamental que o autor depreendeu do estudo das manifestações da arte poética ao largo de toda a história da poética ocidental: o conceito de literatura como estrutura; o problema da relação entre arte poética e mundo; o problema da criatividade poética e a reflexão sobre a linguagem (DOLEZEL, 1990, p. 21).

No mover obsessivo entre os signos, a poesia eugeniana investiga cada um dos problemas citados acima: ao perseguir o modelo orgânico do "fruto", apresenta uma imagem da poesia como estrutura; na movimentação do signo da "ave", investiga o problema da criatividade e sua relação com a construção de uma identidade poética. A "ave" ainda promove uma reflexão sobre a linguagem - assim como todos os demais signos, mesmo que, às vezes, de modo mais indireto -, pois evidencia os diferentes níveis que entram em jogo na composição de cada palavra, confrontando os substratos mítico, sensorial e afetivo da linguagem com os demais saberes que participam da vida social e política do homem moderno, e que são descobertos também no ato da leitura. Através do "navio", a poesia eugeniana reflete sobre as relações entre poesia e mundo, já que esse signo contribui para a dramatização política do ato poético, principalmente em face do cenário conturbado do país sob o jugo da ditadura. A "luz" ou o "fogo" também poderiam estar associados ao problema da criatividade, já que trazem à baila o lugar da "inspiração" e da "revelação" no processo constitutivo da poesia. A "água" aponta para os processos inconscientes da escrita, bem como da memória e da influência materna, além de investigar o problema da recepção poética. Por fim, a reunião de grande parte dos principais signos eugenianos no espaço-tempo do "verão" parece oferecer também uma reflexão sobre a relação entre poética e mundo, especialmente porque o "verão" lança a hipótese da poesia como luta contra a morte; da escrita como embate ou como procura do silêncio - hipótese reverberada, por sua vez, pelo signo do "mar".

Ao acompanharmos o movimento rotatório dos signos em Poemas, acreditamos ter conseguido traçar certas relações de sentido, sempre ondulatórias e, de algum modo, precárias, pois ditadas por imagens que regressam explícita ou implicitamente, refletindo todas as demais, adiando o sentido para uma leitura que se quer cada vez mais 
ampla e total - a realizar-se, talvez, no mito cíclico (ou "espiralado") da própria obra, sempre incompleto e infinito. Assim, como temos procurado observar, cada imagem recorrente torna-se um "signo" versátil, que encarna como função o próprio ato da escrita errante, a formular uma arte poética que aspira, antes de tudo, captar a essência da própria vida e da natureza humana: sempre contínua e transitória. 


\section{BIBLIOGRAFIA}

\section{Bibliografia ativa de Eugénio de Andrade}

ANDRADE, Eugénio. Poemas - 1945-1965. Lisboa: Portugália, 1966.

Antologia Breve, Porto: Editorial Inova Limitada, 1972.

Poesia e prosa. Vols. I e II. Lisboa: Limiar, 1990.

. Entrevista em Macau, N. 29, Macau: Imprensa Oficial, novembro de 1990.

. Rosto precário, em Eugénio de Andrade, Poesia e Prosa, Vila da Maia: Imprensa Nacional, 1980.

Poesia. $2^{\mathrm{a}}$ ed. revista e acrescentada. Posf. de Arnaldo Saraiva. Porto: Fundação Eugénio de Andrade, 2005.

. Entrevista_Between Brutality and Tenderness. Entrevista concedida a Paulo da Costa. 17/09/2006. http://www.paulodacosta.com/eugeniode.htm, acessado 02/12/2010.

. Entrevista "Ser poeta é fácil; ou então é impossível", em Palavra de poeta --- Portugal, Denira Rozário, RJ: Civilização brasileira, 1994.

. Entrevista em Viagem à literatura portuguesa contemporânea, Cremilda de Araújo Medina, RJ: Nórdica, 1983.

\section{Bibliografia passiva sobre Eugénio de Andrade}

AIELlO, Maria Lígia Martha. A Poesia de Eugênio de Andrade em tempo de metamorfose, Bauru: Faculdade do Sagrado Coração, 1985.

BENTO, JOSÉ. "Poemas de Eugênio de Andrade". In: 21 ensaios sobre Eugênio de Andrade. Porto: Inova, 1971, col. Civilização Portuguesa.

BOECHAT, Virgínia. "Do fogo descer à neve com Eugénio de Andrade". In: ALVES, Ida (org.); MAFFEI, Luis (org.). Poetas que interessam mais: estudos sobre poesia portuguesa contemporânea. Rio de Janeiro: Azougue / FAPERJ, 2011.

COELHO, Eduardo Prado. "Relatório duma leitura da poesia de Eugénio de Andrade, e do prazer que ela provoca no leitor". In: 21 ensaios sobre Eugênio de Andrade. Porto: Inova, 1971, col. Civilização Portuguesa.

. A Palavra sobre a Palavra. Porto: Porucalense Editora, 1972. 
. O Reino Flutuante. Lisboa, Edições 70, 1972.

. "Óscar Lopes sobre Eugénio de Andrade", em A mecânica dos fluidos -

literatura, cinema, teoria. Col. Temas portugueses, Lisboa: INCM, 1984.

CRUZ, Gastão. A poesia contemporânea hoje. Lisboa: Plátano Editora, 1973.

“1958 - as imagens”, Metamorfoses, n. 6, 2005.

CRUZ, José da (org.). Ensaios sobre Eugénio de Andrade. Porto: Asa, 2005.

EIRAS, Pedro. "O regresso dos deuses - sobre a poesia de Eugénio de Andrade".

Revista Relâmpago, n. 15, Ano VIII, 10/2004.

FERRAZ, Eucanaã. "Eugénio: Animal Amoroso". Revista Relâmpago, n. 15, Lisboa: Assírio \& Alvim, 10/2004.

FERREIRA, Antonio Manuel. Estudos de Literatura portuguesa, Aveiro: edições Til, 2006.

. "Eugénio de Andrade: figuras de melancolia". In A luz de Saturno figurações da velhice. Aveiro: UA, 2005. p. 53-66.

. "Estou de passagem: amo o efềmero: modulações do carpe diem na poesia de Eugénio de Andrade". Aveiro: UA, 2005.

FERREIRA, Vergílio. "Breve périplo vocabular da poesia de Eugénio de Andrade", em 21 ensaios sobre Eugénio de Andrade. Porto: Editorial Inova, 1971.

GUIMARÃES, Fernando. A poesia contemporânea portuguesa. V.N. Famalicão: Quasi edições, 2002.

Caminho, 1989.

. A poesia contemporânea portuguesa e o fim da modernidade. Lisboa:

. Simbolismo, modernismo e vanguardas. Porto: Lello \& Irmãos, 1992.

. Linguagem e Ideologia. Porto: Editorial Inova, 1972.

. Os problemas da modernidade. Lisboa: Editorial Presença, 1994.

. A obra de arte e o seu mundo, V. N. Famalicão: Quase edições, 2007.

LOPES, ÓSCAR. Uma espécie de música - a poesia de Eugênio de Andrade. Porto: Campo das Letras, 2001.

. Cifras do tempo. Lisboa: Editorial Caminho, Col. Universitária, 1990.

. "O quebrar dos espelhos", Ler e depois - crítica e interpretação literária/l. Porto: Editorial Inova, 1969. 
LOURENÇO, Eduardo. "A poesia de Eugênio de Andrade", 21 ensaios sobre Eugênio de Andrade. Porto: Inova, 1971, col. Civilização Portuguesa.

Edições Asa, 2007.

Paraíso sem mediação: breves ensaios sobre Eugénio de Andrade. Porto: Tempo e poesia, Lisboa: Gradiva, 2003.

. Mitologia da saudade. São Paulo: Companhia das letras, 1999.

MANCELOS, João de. O marulhar de versos antigos: a intertextualidade em Eugénio de Andrade. Lisboa: Edições Colibri, 2009.

MARINHO, Fátima. A poesia portuguesa nos meados do século XX- rupturas e continuidades, Lisboa: Editorial Caminho, 1989.

MARTELO, Rosa Maria. Vidro do mesmo vidro. Porto: Campo das Letras, 2007.

. A forma informe: leituras de poesia, Lisboa: Assírio \& Alvim, 2010.

MENDONÇA, José Tolentino. "A narrativa do silêncio em Eugénio de Andrade". Ensaio sobre Eugénio de Andrade. Porto: Edições Asa, 2003.

MONTEIRO, Adolfo Casais. A palavra essencial : estudos sôbre a poesia. São Paulo : Companhia Editora Nacional, 1965.

MOURÃO-FERREIRA, David. Vinte Poetas contemporâneos. Lisboa: Edições Ática, 1980.

MOURÃO, Paula. Poemas de Eugênio de Andrade (O homem, a Terra, a Palavra), Lisboa, Seara Nova, Editorial Comunicação, 1981.

NAVA, Luís Miguel; CRESPO, Ángel. Apresentação de Eugénio de Andrade, o amigo mais íntimo do sol, Fotobiografia. Campo das letras, 1998.

da Moeda, 1987.

O Essencial sobre Eugénio de Andrade, Maia: Imprensa Nacional - Casa . Ensaios reunidos. Lisboa: Assírio \& Alvim, 2004.

REYNAUD, Maria João. "A poesia de Eugênio de Andrade: esboço de uma leitura", em Revista da Faculdade de letras, Línguas e Literaturas, Porto XI, 1994.

ROCHA, Pereira Maria Helena. "O mundo clássico em Eugénio de Andrade". Portugal e a Herança Clássica e Outros Textos. Porto: Edições Asa, 2003.

. "Poesia de Safo em Eugénio de Andrade". Novos ensaios sobre temas clássicos na poesia portuguesa. Lisboa: Imprensa Nacional - Casa da Moeda, 1971. 
. "Em volta das palavras aladas". Novos ensaios sobre temas clássicos na poesia portuguesa. Lisboa: Imprensa Nacional - Casa da Moeda, 1971.

ROSA, António Ramos. Poesia, liberdade livre, Lisboa: Livraria Morais Editora, 1962. A poesia moderna e a interrogação do real (volumes 1 e 2), Lisboa, Arcádia, 1980.

. A parede azul - Estudos sobre poesia e artes plásticas. Lisboa: Caminho, 1991.

. Incisões oblíquas: estudos sobre poesia portuguesa contemporânea. Lisboa: Caminho, 1987.

RUBIM, Gustavo. O animal poético. In Relâmpago - revista de poesia: Eugénio de Andrade. no 15. Lisboa: Fundação Luís Miguel Nava, 2004. p. 57-86.

SARAIVA, Antonio José; LOPES, Óscar. História da Literatura Portuguesa. Porto: Porto Editora, 1955.

- "Todo o oiro do dia", Triceversa, Revista do Centro Ítalo-LusoBrasileiro de Estudos Linguísticos e Culturais, ISSN 1981 8432, Assis, v.1, n.1, maio-out. 2007.

SENA, Jorge de. Dialéticas aplicadas da literatura. Lisboa: edições 70, 1978. . Estudos de Literatura Portuguesa I, Lisboa: Edições 70, 2001. . Estudos de Literatura Portuguesa II, Lisboa: Edições 70, 2001. . Estudos de Literatura Portuguesa III, Lisboa: Edições 70, 2001. . Dialéticas aplicadas da literatura. Lisboa: Edições 70, 1978. . Liricas portuguesas. Lisboa, Edições 70, 1984.

. “A poesia de Camões", Trinta anos de Camões (1948-1978), vol. I, Lisboa: Edições 70, 1980.

SERRÃO, José. "Cronos, Eros e Tanatos nas palavras do poeta”, em 21 ensaios sobre Eugênio de Andrade. Porto: Editorial Inova, 1971.

SOUSA, Carlos Mendes. O nascimento da música - a metáfora em Eugénio de Andrade. Coimbra: Livraria Almedina, 1992.

TORRES, Alexandre Pinheiro. "O conflito entre o instinto e a sociedade em As mãos e os frutos de Eugénio de Andrade", em 21 ensaios sobre Eugénio de Andrade, Porto: Editorial Inova, 1971. 
VÁRIOS AUTORES. Cadernos de Poesia, reprodução fac-similada dirigida por Luís Adriano Carlos e Joana Matos Frias, Coleção Clássicos Portugueses, Porto: Campo das Letras, 2004.

VÁRIOS AUTORES. 21 ensaios sobre Eugénio de Andrade, Porto: Editorial Inova, 1971.

\section{Biliografia teórico-crítica}

ABBAGNANO, Nicolas. Dicionário de filosofia. Tradução Bosi, SP: Martins Fontes, 2003.

ACHCAR, Francisco. Lírica e lugar-comum - alguns temas de Horácio e sua presença em português. São Paulo: Edusp, 1994.

ADORNO, Theodor. "Lírica e sociedade", In: Benjamin, Horkheimer, Adorno, Habermas. Textos escolhidos. (Col. Os Pensadores). São Paulo: Abril Cultural, 1980.

AMARAL, Fernando Pinto. Um século de poesia (1888-1998), Lisboa, Assirio \& Alvim, 1988.

Discurso e imagens da melancolia na poesia portuguesa do século XX.

Lisboa: 1997 (tese de doutorado).

ARANTES, José Antônio. "A imagem de Blake", em $O$ matrimônio do céu e do inferno - O livro de Thel, São Paulo: Iluminuras, 2001.

ARISTÓTEleS, HORÁCIO, LONGINO. A Poética Clássica. São Paulo: Editora Cultrix, 2005.

ASSUNÇÃO, Teodoro Rennó. "Ulisses e Aquiles repensando a morte: Odisséia XI, 478 - 491”. Kriterion: Revista de Filosofia, volume 44, n. 107, BH: Junho, 2003.

BACHELARD, Gaston. A poética do espaço. São Paulo: Martins Fontes, 2000.

- A água e os sonhos - ensaio sobre a imaginação da matéria. São Paulo:

Martins Fontes, 2002.

. A chama de uma vela. Rio de Janeiro: Editora Bertrand, 1989.

. Fragmentos de uma poética do fogo. São Paulo: Editora Brasiliense, 1990.

BALAKIAN, Anna. São Paulo: Perspectiva, 2007.

BARBOSA, João Alexandre. Imitação da forma. São Paulo: Duas Cidades, 1975. As ilusões da modernidade. São Paulo: Perspectiva, 2005.

BARRENTO, João. O arco da palavra, São Paulo: Escrituras, 2006. 
. "Que significa 'moderno'?” A espiral vertiginosa: ensaios sobre a cultura contemporânea. Lisboa: Cotovia, 2001.

BARTHES, R. Fragmentos de um discurso amoroso. Trad. Hortência dos Santos. Rio de Janeiro: Livraria Francisco Alves, 1981.

BASTOS, Daniel. "Para uma história das eleições presidenciais de 1949 e 1958 na Vila de Fafe", $\quad$ http://www.museu-emigrantes.org/ARTIGOEleiçõesPresidenciaisnaViladeFafe(1949-58).pdf (acesso 15/08/2012, 15:53)

BELO, RUY. Na senda da poesia, Lisboa 1969.

BENJAMIN, Walter. A modernidade e os modernos. Rio de Janeiro: Tempo Brasileiro, 2000.

Obras escolhidas III - Charles Baudelaire: um lírico no auge do capitalismo. São Paulo: Editora Brasiliense, 2000.

BERARDINELLI, A. Da poesia à prosa. São Paulo: Cosacnaify, 2007.

BERGEZ, D., BARBÉRIS, P., BIASI, P., MARINI, M. e VALENCY, G. Métodos críticos para a análise literária. São Paulo: Martins Fontes, 2006.

BERMAN, Marshall. Tudo que é sólido desmancha no ar. São Paulo: Editora Schwarcz, 1992.

BUESCU, Helena Carvalhão. Dicionário de Fernando Pessoa e do modernismo português, org. Fernando Cabral Martins, Caminho, Lisboa: 2008.

BUESCU, Maria Leonor. Iniciação à literatura portuguesa. Lisboa: Plátano Editora, 1973.

BLAKE, William. Poesia e prosa selecionadas, edição bilíngue organizada e traduzida por Paulo Vizioli, São Paulo: Nova Alexandria, 1993.

BLANCHOT, Maurice. A parte do fogo. Rio de Janeiro: Rocco, 1997. . A conversa infinita. A palavra plural. São Paulo: Escuta, 2001. O espaço literário, Rio de Janeiro: Rocco, 1987.

BREMOND, Henri. La poesia pura, Buenos Aires: Argos, 1947.

BOSI, Alfredo. "Introdução ao Estudo da Poesia". In: Leitura de Poesia. São Paulo, Ática, 1996.

O ser e tempo da poesia. São Paulo: Ed. Cultrix, 1977. 
. "O tempo e os tempos", em Tempo e história, org. Adauto Novaes, Companhia das Letras, SP: 1994. Reflexões sobre a arte. São Paulo: Ática, 1985.

BORGES, J.L. Esse oficio do verso. SP: Companhia dasletras, 2000.

BORNSTEIN, George. "Ezra Pound and the making of modernism", em The Cambridge companion to Ezra Pound, Cambridge University Press, 1999.

BRICOUT, Bernadette (org.). O olhar de orpheu: os mitos literários do ocidente. São Paulo: Companhia das letras, 2003.

BROOKS, Cleanth e WARREN, R. P. - Understanding poetry. New York, Holt Rinehart and Winston, 1960.

BÜRGER, Peter. Teoria da vanguarda. Trad. José Pedro Antunes. São Paulo: Cosac Naify, 2008.

BURKE, K. Teoria da forma literária. Tradução José Paulo Paes. São Paulo: Cultrix, 1969.

BUTZER, Günter; JACOB, Joachim (org.). Metzler Lexikon literarischer symbole. J.B. Metzler: Stuttgart, 2008.

CALASSO, Roberto. A Literatura e os deuses. São Paulo: Companhia das Letras, 2004.

CALINESCU, Matei. Five Faces of Modernity. Durham: Duke University Press, 1987.

CALVINO, ITALO. Seis propostas para o próximo milênio, trad. Ivo Barroso, São Paulo: Companhia das Letras, 1991.

CAMPOS, Haroldo. A arte no horizonte do provável. São Paulo: Editora Perspectiva, 1969.

. Metalinguagem e outras metas. São Paulo: Editora Perspectiva, 1992.

CANDIDO, Antonio. "Literatura e Cultura", In: Literatura e sociedade. São Paulo: Companhia Editora Nacional, 1976.

. O estudo analítico do poema. São Paulo: Humanitas Publicações, 2006.

CASSIRER, Ernst. A filosofia das formas simbólicas. Vol $1-$ A linguagem. Vol. $2-O$ pensamento mítico, São Paulo: Martins Fontes, 2009.

Linguagem e mito. São Paulo: Perspectiva, 2009.

CASTRO, E.M. O próprio poético. Lisboa: Quiron, 1973. 
CARONE, Modesto. A poética do silêncio. São Paulo: Editora Perspectiva, 1979.

CARPEAUX, Otto Maria. "Poesia e ideologia", em Origens e fins. Rio de Janeiro: CEB, 1943.

CEIA, Carlos. Textualidade. Uma introdução. Lisboa: Editorial Presença, 1995.

CESARINY, Mário. A intervenção surrealista. Lisboa: Assírio \& Alvim, 1997.

CHAUI, Marilena. "Laços do desejo", em O desejo, organização de Adauto Novaes, SP: Companhia das letras, 1995.

2002.

Introdução à história da filosofia, vol 1, São Paulo: Companhia das letras,

CHEVALIER, Jean; e GHEERBRANT, Alain, Dicionário de Símbolos, RJ: José Olympio Editora, 1999.

CHKLOVSKI. "A arte como procedimento", em Teoria da literatura --- formalistas russos, editora globo, Porto Alegre, 1978.

COELHO, Jacinto do Prado. "Alguns temas da moderna poesia portuguesa", em A letra e o leitor. Lisboa: Lello Editores, 1996.

COHEN, Jean. Estrutura da Linguagem Poética, São Paulo: Cultrix, 1974.

COMPAGNON, Antoine. Os cinco paradoxos da modernidade. Belo Horizonte: UFMG, 2010.

CORREA, Natália. Cantares dos trovadores galego-portugueses, Lisboa: Estampa, 1978.

CROCE, Benedetto. A poesia - introdução à crítica e história da poesia e da literatura, tradução de Flávio Loureiro Chaves, UFRGS, Porto Alegre, 1967.

CUNHA, Celso. Gramática do português contemporâneo. Belo Horizonte: Editora Bernardo Alvares, 1972.

DANTAS, José Maria de Souza. Imagem poética, linguagens, modernidade. São Paulo: Difel, 1979.

DELEUZE, G. Lógica do sentido. São Paulo: Perspectiva, 2007. . "Désir et plaisir". Magazine Littéraire. Paris, n. 325, oct, 1994, pp. 57-65.

DOLEZEL, Lubomír. A poética ocidental, Lisboa: Fundação Calouste Gulbenkian, 1990.

DUBOIS, Jacques, EDELINE, Francis, KLINKENBERG, Jean-Marie, e 
MINGUET, Philippe. Tradução de Carlos Filipe Moisés. Retórica da poesia: leitura linear, leitura tabular. São Paulo: Editora Cultrix, 1980.

ELIADE, Mircea. "The prestige of the cosmogonic myth". Myth: critical concepts in literary and cultural studies, edited by Robert A. Segal. Volume IV, New York: Routledge, 2007.

ELIOT, T.S. "Tradition and the individual talent", em Selected essays, London: Faber and Faber, 1951.

FERBER, Michael. A dictionary of literary symbols. Cambridge: University Press, 1999.

FERREIRA, Ana Sofia. "As eleições no Estado Novo: as eleições presidenciais de 1949 e 1958", Revista da Faculdade de Letras -HISTÓRIA, Porto, III Série, vol. 7, 2006, pp. 197-212.

FILHO, Leodegário A. de Azevedo. As cantigas de Pero Meogo, RJ: edições Gernasa, 1974.

FONTES, Joaquim Brasil. Eros, tecelão de mitos. São Paulo: Iluminuras, 2003.

FRANÇA, José-Augusto. A arte e a sociedade portuguesa no século XX (19101990), Lisboa: Livros Horizonte, 1991.

FRANCHETTI, Paulo. Nostalgia, exílio, melancolia: leituras de Camilo Pessanha, São Paulo: Edusp, 2001.

FRIEDRICH, HUGO. A estrutura da lirica moderna. São Paulo: Duas Cidades, 1978.

FRYE, Northrop. Fábulas de identidade: estudos de mitologia poética. Trad. Sandra Vasconcelos. São Paulo: Nova Alexandria, 2000.

GANDILLAC, Maurice de. "O amor na idade média", O Desejo, org. Adauto Novaes, SP: Companhia das letras, 1999.

GOETHE, J. W. Viagem à Itália (1786-1788), trad. Sérgio Tellaroli, São Paulo: Companhia das Letras, 1999.

GRIMAL, Pierre. Dicionário da Mitologia Grega e Romana, Rio de Janeiro: Bertrand Brasil, 1997.

HAMBURGER, Michael. A verdade da poesia. SP: Cosacnaify, 2007.

HAMBURGER, Kate. A lógica da criação literária. São Paulo: Editora Perspectiva, 1975.

HANSEN, João Adolfo. Alegoria: construção e interpretação da metáfora. São Paulo: Hedra/Editora da Unicamp, 2006. 
HASSAN, IHAB. The Dismemberment of Orpheus --- Toward a Postmodern literature, Madison, University of Wisconsin Press, 1982.

HATHERLY, Ana. O espaço crítico - do simbolismo à vanguarda. Lisboa: Editorial Caminho, 1979.

HAUSER, Arnold. História social da arte e da literatura. São Paulo: Martins Fontes, 1998.

HEIDEGGER, Martin: On the way to language. Harper \& Row, 1982.

HESS, Rainer. Os inícios da lírica moderna em Portugal. Imprensa Nacional/Casa da Moeda, 1999.

HUMPHREYS, Richard. Futurismo. São Paulo: Cosac \& Naify, 1999.

JAKOBSON, Roman. Arte verbal, signo verbal, tiempo verbal. México : Fondo de Cultura Económica, c1992. . Poética em ação. São Paulo : Perspectiva, 1990.

1973, pp. 5-9. “O que fazem os poetas com as palavras”. In: Colóquio, no 12, março de

JIMENEZ, Marc. O que é estética?Trad. Fulvia M. L. Valls. São Leopoldo do Rio Grande do Sul: Editora Unisinos, 2008.

JOLLES, André. Formas simples. Trad. Álvaro Cabral. São Paulo: Cultrix, 1976.

JUDICE, Nuno. As máscaras do poema. Lisboa: Aríon Publicações, 1998.

d'água editores, 1997. - Viagem por um século de literatura portuguesa, Lisboa: Relógio . O processo poético. Viseu: Imprensa Nacional/ Casa da Moeda, 1992.

JUNG, C.G. Símbolos da Transformação. Petrópolis: Editora Vozes, 1986.

KENNER, Hugh: The Pound Era. UCalifornia Press, 1973.

KRISTEVA, Julia. Histórias de amor, trad. Leda Tenório da Motta, RJ: Paz e Terra, 1988.

KRAUSZ, L. As musas. São Paulo: Edusp, 2007.

LAGES, Susana Kampff. Walter Benjamin - Tradução e melancolia. São Paulo: Edusp, 2002.

LEIRIA, Mário-Henrique. Imagem devolvida, poema-mito. Lisboa: Plátano Editora, Coleção "Imagens", 1974. 
LEMINSKI, Paulo. "Poesia: a paixão da linguagem", Os sentidos da paixão, org. Adauto Novaes, SP: Companhia das letras, 1999.

LEMOS, Esther de. A Clepsidra de Camilo Pessanha. Viseu: Editorial Verbo, 1981.

LIMA, Luis Costa. Lira e antilira. Rio de Janeiro: Civilização Brasileira, 1974. . A literatura e o leitor - textos de estética da recepção. São Paulo: Paz e terra, 2002.

LUCAS, Fábio. Fontes Literárias Portuguesas. Campinas: Pontes, 1991.

LUGOWSKI, Clemens. Form, Individuality and the Novel. Oklahoma: University Press, 1990.

MARÍAS, Julián. História da filosofia, Porto: Edições Sousa \& Almeida, 1978.

MARITAIN, Jacques. A intuição criadora na arte e na poesia. Trad. Moacyr Laterza e Léa F. Laterza, Belo Horizontes: Laboratório de estética, UFMG, 1982.

MARSICANO, A. "A trilha errante do Haikai". Trilha estreita ao confim. São Paulo: Editora Iluminuras, 1997.

MARTINHO, Fernando J. B. Tendências dominantes da poesia portuguesa da década de 50. Lisboa: Edições Colibri, 1996.

. "Depois do Modernismo, o quê?", in Semear. Revista da Cátedra Padre Antonio Vieira de Estados Portugueses, n.4, RJ: 2000.

MARTIN, P.W. Experiment in depth. London: Routledge \& Kegan Paul, 1964.

MATTOSO, José. História de Portugal, vol. 7, Lisboa: Editorial Estampa, 1995.

MAXWELL, Kenneth. The making of Portuguese democracy, Cambridge: University Press, 1995.

MELETÍNSKI, E. Os arquétipos literários. São Paulo: Ateliê Editorial, 2002.

MOISÉS, Carlos Felipe. Poesia e realidade. São Paulo: Cultrix, 1977.

MURICY, Kátia. "Benjamin: Política e paixão", Os sentidos da paixão, organização de Adauto Novaes, SP: Funarte e Companhia das letras, 1999.

NOVAES, Adauto (org.). Poetas que pensaram o mundo. São Paulo: Companhia das letras, 2005.

NUNES, Benedito. Hermenêutica e Poesia. Belo Horizonte: Humanitas, 2007. 
. “A visão Romântica”. In: O Romantismo, org. J. Guinsburg. São Paulo: Editora Perspectiva, 1978.

OLIVEIRA, António Falcão Rodrigues. O simbolismo de Camilo Pessanha, Lisboa: Edições Ática, 1979

PAES, José Paulo. "Erotismo e poesia: dos gregos aos surrealistas". In: Poesia erótica em tradução. Sel., trad.,intr. e notas José Paulo Paes. São Paulo: Companhia das Letras, 1990.

PAZ, Octavio. "El Surrealismo", em El surrealismo, org. de Vitor García de La Concha, Madrid: Taurus, 1982.

. "Os signos em rotação", Trad. Sebastião Uchoa Leite, Signos em rotação, SP: Editora Perspectiva, 1976. . A outra voz. São Paulo: Siciliano, 1993.

O arco e a lira, Rio de Janeiro: Nova Fronteira, 1982.

Os filhos do barro. Trad. Olga Savary. Rio de Janeiro: Nova Fronteira, 1984. . A dupla chama. Amor e Erotismo. São Paulo: Editora Siciliano, 1994. . Octavio Paz: obras completas. Ed. do autor. Cidade del Mexico: Fondo de cultura econômica /Letras mexicanas, 1994.

PERRONE-MOISÉS, Leyla. "Pensar é estar doente dos olhos", em $O$ olhar, org. Adauto Novaes, SP: Companhia das Letras, 1988.

PESSANHA, Camilo. Clepsydra, edição crítica de Paulo Franchetti. Lisboa: Relógio D’Água Editores, 1995.

PESSANHA, José Américo Motta. Em "Platão: as várias faces do amor", Os sentidos da paixão, org. Adauto Novaes, SP: Companhia das letras, 1999.

PEIXOTO. Marta. Poesia com coisas. São Paulo: Editora Perspectiva, 1983.

POMORSKA, Krystyna. Formalismo e futurismo. São Paulo: Editora Perspectiva, 1972.

POUND, Ezra. ABC da Literatura. São Paulo: Cultrix, 1990.

Personae. New York: A new directions books, 1990.

PRATT, William. The imagist poem. Oregon: Story Line Press, 2001. 
RAYMOND, Marcel. De Baudelaire ao surrealismo, São Paulo: Edusp, 1997.

RECKERT, S. Para além das neblinas de novembro. Lisboa: Fundação Calouste Gulbenkian, 1999.

. Do cancioneiro de amigo. Co. Helder Macedo. Lisboa: Assírio \& Alvin, 1996.

REIS, Carlos; LOPES, Ana Cristina M. Dicionário de teoria da narrativa. São Paulo: Editora Ática, 1988.

RIBEIRO, Renato Janine. "A paixão revolucionária e a paixão amorosa em Stendhal", Os sentidos da paixão, SP: Funarte/ Companhia das letras, 1999.

RIFFATERRE, Michael. A produção do texto. São Paulo: Martins Fontes, 1989.

ROCHA, Clara. Revistas Literárias do Século XX em Portugal. Lisboa: Imprensa Nacional - Casa da Moeda, "Temas Portugueses".

ROSENFELD, Anatol - "A teoria dos gêneros". In: O teatro épico. S. Paulo. Perspectiva, 1986.

ROSENFIELD, Kathrin. A linguagem liberada. São Paulo: Editora perspectiva, 1989.

RUTHVEN, K.K. O mito. São Paulo: Perspectiva, 1997.

SAMOYAULT, Tiphaine. A intertextualidade. São Paulo: Aderaldo \& Rothschild, 2008.

SANTIAGO, Silviano “A permanência do discurso da tradição no Modernismo". In: Nas malhas da letra. São Paulo: Companhia das Letras, 1989.

SARTRE, Jean-Paul. Que é a literatura? São Paulo: Editora Ática, 2006.

SHAKESPEARE, William. Antony and Cleopatra, London: the Arden Shakespeare, 2006.

SCHLAFER, Heinz. Poesie und Wissen. Die Entstehung des ästhetischen Bewußtseins und der philologischen Erkenntnis. Frankfurt am Main: Suhrkamp, 1990.

SCHLEGEL, F. O dialeto dos fragmentos. São Paulo: Iluminuras, 1997.

SERRÃO, Joel. Temas de Cultura Portuguesa. Vol II. Lisboa: Livros Horizonte, 1989.

SILVEIRA, Jorge Fernandes da. Discurso/desconcerto: alguns nós na literatura portuguesa. Verso com verso. Coimbra: Angelus Novus, 2003. p. 41-58.

SIMAS, M. "O surrealismo português em perspectiva", em Literatura portuguesa: história, memória e perspectivas. São Paulo: Alameda, 2007. 
SIMÕES, J. História da Poesia Portuguesa. Lisboa: Empresa Nacional de Publicidade 1955. . Itinerário da Poesia Portuguesa. Porto: Porto Editora, s/d. . Em Perspectiva Histórica da Poesia Portuguesa (século XX), Porto: Brasília Editora, 1976.

SOUZA, R. M. "Raul Brandão na revista Seara Nova". Revista Crioula, N.2, São Paulo, Novembro, 2007.

SPINA, Segismundo. A lírica trovadoresca, São Paulo: EDUSP, 1996. . Do formalismo estético trovadoresco. São Paulo: Ateliê Editorial, 2009. . Na madrugada das formas poéticas. São Paulo: Ateliê editorial, 2002.

STAGGIARI, Bárbara. O simbolismo na obra de Camilo Pessanha. Lisboa: 1982. STEWART, Susan. Poetry and the fate of the senses, Chicago: University Press, 2002. STRAUSS, Lévi. "The structural study of myth". Myth - critical concepts in literary and cultural studies. London/NY: Routledge, 2007

SUBIRATS, Eduardo. Da vanguarda ao pós-moderno. São Paulo: Nobel, 1987.

TAUPIN, René. The Influence of French Symbolism on Modern American Poetry. New York: AMS Press, 1985.

TAVANI, Giuseppe. Trovadores e jograis: introdução à poesia medieval galegoportuguesa. Lisboa: Editorial Caminho, 2002.

TCHEN, Adelaide Ginga. A aventura surrealista, Lisboa: Edições Colibri, 2001.

TINIANOV, Iuri. "O problema da linguagem poética I" e "O ritmo como elemento constitutivo do verso", em Diagrama 5, Rio de Janeiro: Tempo brasileiro, 1975.

TODOROV, Tzvetan. Teorias do símbolo. São Paulo: Papirus Editora, 1996. . Poética. Tradução de António José Massano. Lisboa: Teorema, 1993. . Teorias do símbolo. São Paulo: Papirus, 1996.

TORGAL, Luís Reis. “O Estado Novo. Salazarismo, Fascismo, Europa.” In: História de Portugal . José Tengarrinha (org.), Editora Unesp, 2001.

VALÉRY, Paul. Variedades. São Paulo: Iluminuras, 1999. 
VIEGAS, Francisco José. As Imagens. Coleção "Caminho da poesia" Editorial Caminho, 1997.

VIVAS, Eliseo. Creation And Discovery. New York: Noonday Press, 1955.

WARREN. "Pure and Impure Poetry", in Critique, NY: Stallman, s/d.

WIMSATT, W. e BROOKS, C. Crítica Literária - Breve História. Lisboa: Fundação Calouste Gulbenkian, s/d.

WILSON, Edmund. O castelo de Axel. São Paulo: Ed. Cultrix, [s.d.].

ZAMBRANO, Maria. A metáfora do coração e outros escritos. Lisboa: Assírio \& Alvim, 2000. 


\section{6. $\underline{\text { ANEXO }}$}

\section{POÉTICA (ANDRADE, 1966, pp. 9 a 11)}

O acto poético é o empenho total do ser para sua revelação. Este fogo de conhecimento, que é também fogo de amor, em que o poeta se exalta e consome, é a sua moral. E não há outra. Nesse mergulho do homem nas suas águas mais silenciadas, o que vem à tona é tanto uma singularidade quanto uma pluralidade. Mas, curiosamente, o espírito humano atenta mais facilmente nas diferenças que nas semelhanças, esquecendo-se, e é Goethe quem lembra, que o particular e o universal coincidem, $e$ assim a palavra do poeta, tão fiel ao homem, acaba por ser palavra de escândalo no seio do próprio homem. Na verdade, ele nega onde outros afirmam, desoculta o que outros escondem, ousa amar o que outros são sequer capazes de imaginar. Palavra de aflição mesmo quando luminosa, de desejo apesar de serena, rumorosa até quando nos diz o seu silêncio, pois esse ser sedento de ser, que é o poeta, tem a nostalgia da unidade, e o que procura é uma reconciliação, uma suprema harmonia entre luz e sombra, presença e ausência, plenitude e carência.

Essa revelação do poeta, e dos outros com ele, essa descida ao coração da alma, de que Heraclito encontrou a fórmula, essa coragem de mostrar o que achou no caminhoé o que chamarei agora de dignidade do poeta, e com ele a do homem. Porque é sempre de dignidade que se trata quando alguém dá a ver o que viu, por mais fascinante ou intolerável que seja o achado.

"O futuro do homem é o homem", estamos de acordo. Mas o homem do nosso futuro não nos interessa desfigurado. Este animal triste que nos habita há milhares de anos, cujas possibilidades estamos tão longes de conhecer, é o fruto de uma desfiguração aç̧ão de uma cultura mais interessada em ocultar ao homem seu rosto do que trazê-lo, belo e tenebroso, à luz limpa do dia. É contra a ausência do homem no homem que a palavra do poeta se insurge, é contra esta amputação no corpo vivo da vida que o poeta se rebela. E se ousa "cantar no suplício" é porque não quer morrer sem se olhar nos próprios olhos, e reconhecer-se, e detestar-se ou amar-se, se for caso disso, no que não creio. De Homero a S. Juan de La Cruz, Virgílio a Alexandre Blok, De Li Po a William Blake, de Bashô a Cavafy, a ambição maior do fazer poético foi sempre a mesma: Ecce Homo, parece dizer cada poema. Eis o homem, eis o seu efêmero rosto feito de milhares e milhares de rostos, todos eles esplendidamente respirando na terra, nenhum superior a outro, separados por mil e uma diferença, unidos por mil e uma coisa comum, semelhantes e distintos, parecidos todos e contudo cada um deles único, solitário, desamparado. É a tal rosto que cada poeta está religado. A sua rebeldia é em nome dessa fidelidade. Fidelidade ao homem e à sua lúcida esperança de sê-lo inteiramente, fidelidade à terra, onde mergulha as raízes mais fundas, fidelidade à palavra que no homem é capaz da verdade última do sangue, que é também verdade da alma. 